\title{
An Analysis of the Relationship between Healthcare Spending And Health Outcomes: A Data Analytics Perspective Using The Theory of Production Functions
}

\author{
By \\ Kwadwo Oppong Adu \\ Bachelor of Urban and Regional Planning \\ Ryerson University, 2014 \\ A thesis \\ Presented to Ryerson University \\ In partial fulfillment of the requirements for the degree of \\ Master of Management Science (MMSc) \\ in the program of Management of Technology and Innovation
}

Toronto, Ontario, Canada, 2017

CKwadwo Oppong Adu 2017 


\section{$\underline{\text { Author's Declaration }}$}

I hereby declare that I am the sole author of this thesis. This is a true copy of the thesis, including any required final revisions, as accepted by my examiners.

I authorize Ryerson University to lend this thesis to other institutions or individuals for the purpose of scholarly research

I further authorize Ryerson University to reproduce this thesis by photocopying or by other means, in total or in part, at the request of other institutions or individuals for the purpose of scholarly research.

I understand that my thesis may be made electronically available to the public. 


\title{
Abstract \\ An Analysis of the Relationship between Healthcare Spending and Health Outcomes: A Data Analytics Perspective Using the Theory of Production Functions
}

\author{
Masters of Management Science (MMSc) \\ Management of Technology and Innovation \\ Ryerson University \\ (C) Kwadwo Oppong Adu 2017
}

This research investigates the relationship between per capita spending on healthcare and population health outcomes at the provincial level in Canada using data from 1980 to 2010. The health outcomes examined include life expectancy at birth and at age 65, number of infant deaths, and potential years of life lost from treatable causes, all of which are separated by gender. Using analytics methods as an application of the theory of growth accounting, the study evaluates the performance of the provincial health care systems in terms of their ability to efficiently produce longevity. The study also specifies the categories of healthcare spending which are most influential in determining the efficient production of longevity and measures the contribution of healthcare spending to the determination of infant mortality and deaths from treatable causes. The methods employed include Data Envelopment Analysis, Decision Tree Induction, and Multivariate Adaptive Regression Splines. The results of the analysis point to the fact that Canada's provinces operate inefficiently in their production of health outcomes and confirm the importance of healthcare spending to determining health outcomes in Canada. 


\section{Acknowledgements}

I would like to thank my supervisor Ojelanki Ngwenyama for his guidance in the process of writing this thesis and for challenging me to grow as a scholar and a person. I would also like to thank my family and friends for their love and support along the way as there is no way this

process could have been completed without them. To all of you, I could not have done this without you. Thank you. 


\section{Contents}

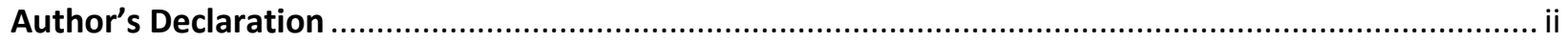

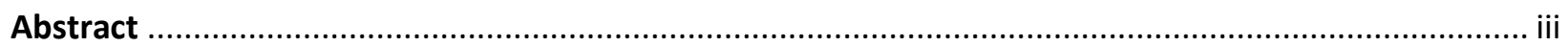

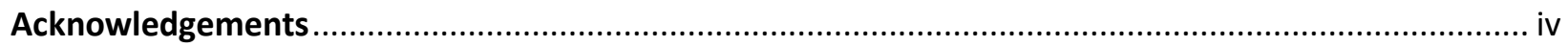

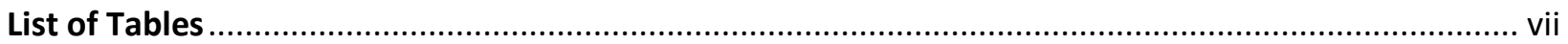

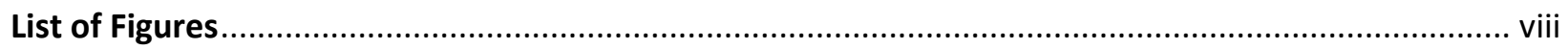

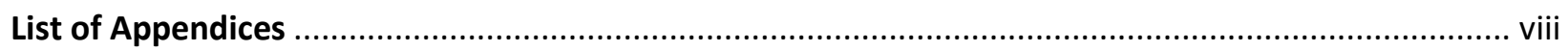

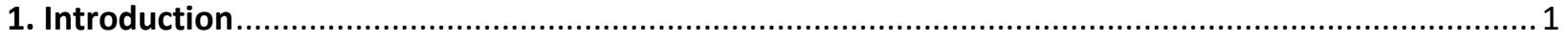

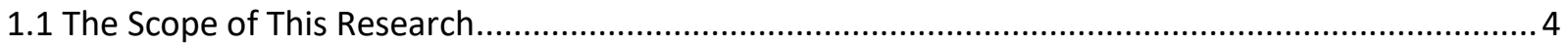

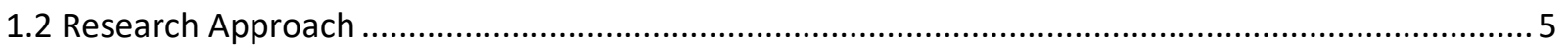

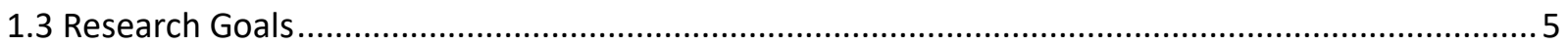

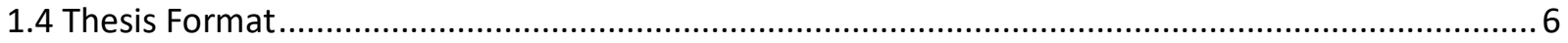

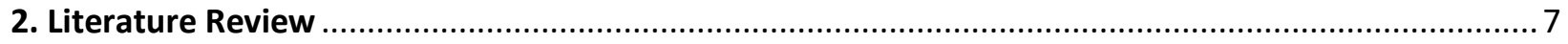

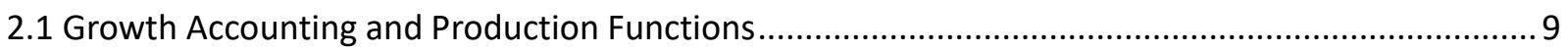

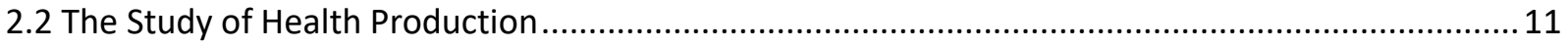

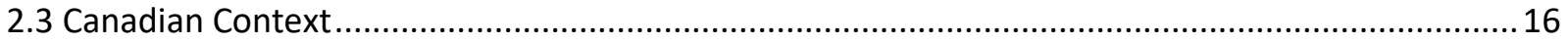

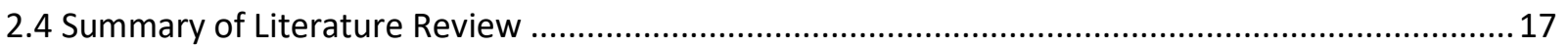

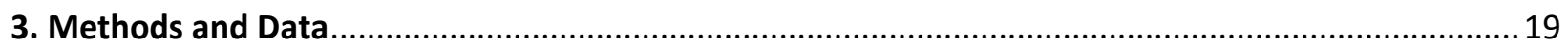

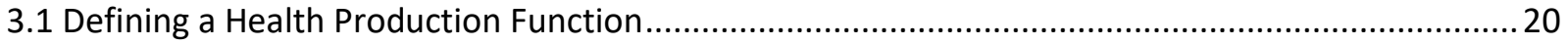

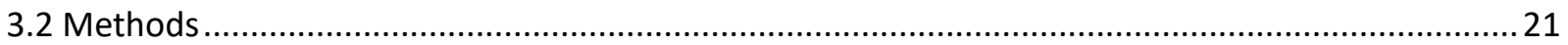

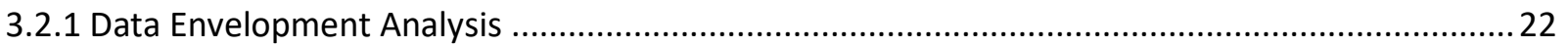

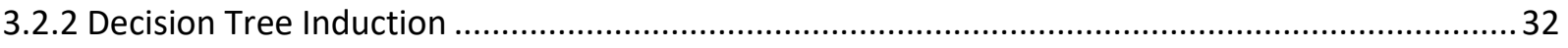

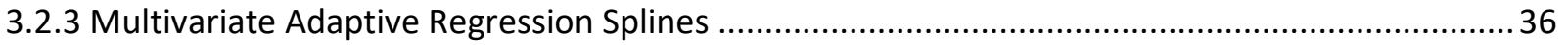

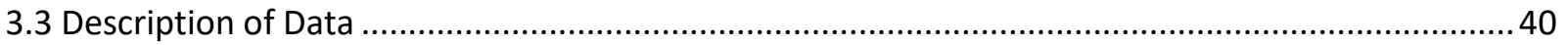

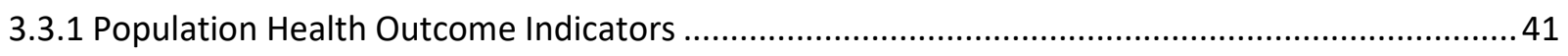

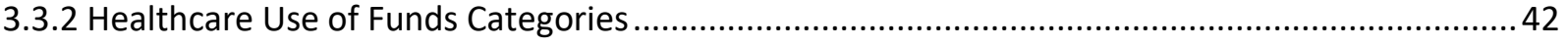

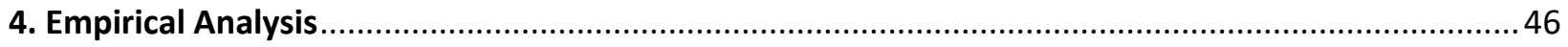

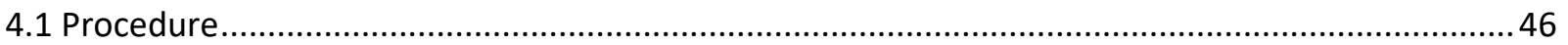

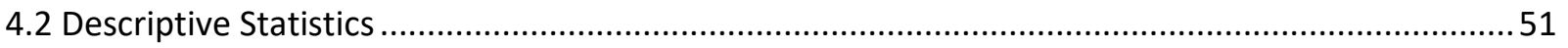

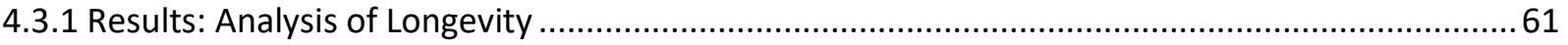

4.3.2 Results: Analysis of Infant Mortality and Deaths from Treatable Causes....................................66

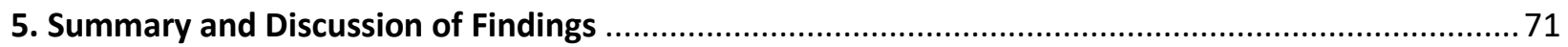




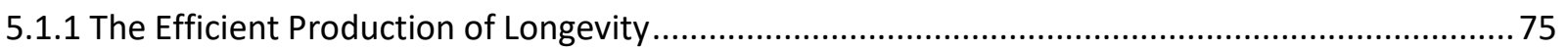

5.1.2 Importance of Spending Categories to the Efficient Production of Longevity ............................ 79

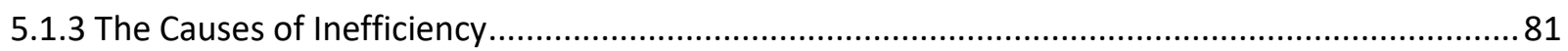

5.2.1 The Importance of Spending to Determining Non-Longevity Health Outcomes.........................85

5.2.2 The Importance of Spending to Determining Deaths due to Treatable Causes ...........................85

5.2.3 The Importance of Spending to Determining Infant Mortality.................................................. 88

5.4 The Contribution of Spending to the Prediction of Health Outcomes .........................................91

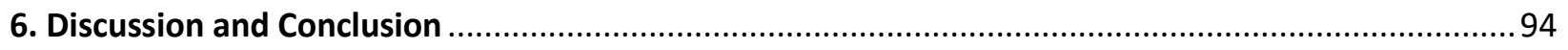

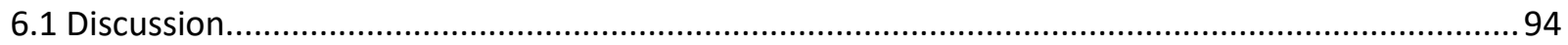

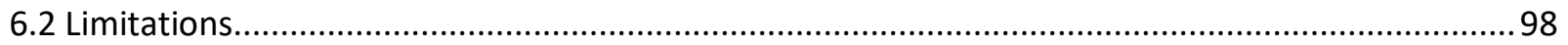

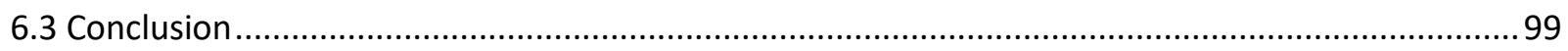

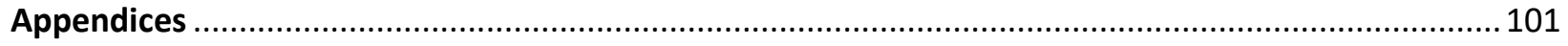

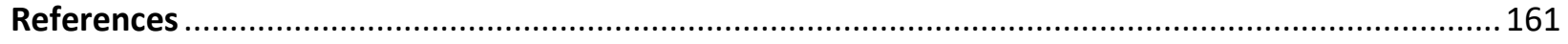

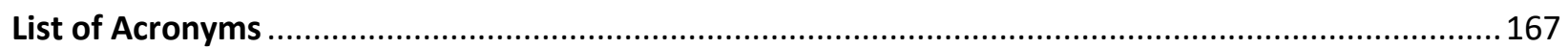

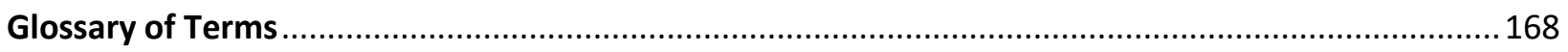




\section{List of Tables}

Table 1: DEA CCR Model.

Table 2: Explanation of Simple and Complex Basis Functions.

Table 3: Female Life Expectancy at Age 65 by Province, Annually - 1980 to 2007.............................. 53

Table 4: Female Life Expectancy at Birth by Province, Annually - 1980 to 2007 ................................ 54

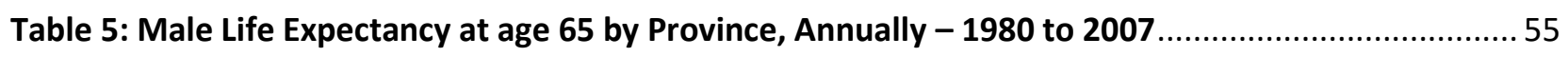

Table 6: Male Life Expectancy at Birth by Province, Annually - 1980 to 2007 .................................. 56

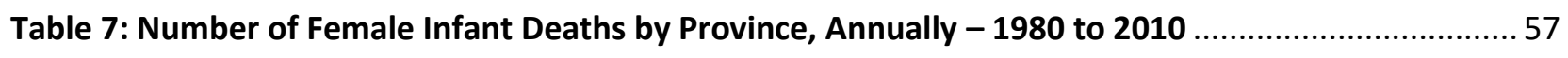

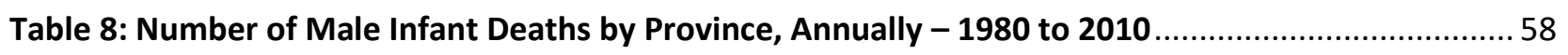

Table 9: Potential Years of Life Lost by Females due to Treatable Causes by Province, Annually - 1980 to 2010

Table 10: Number of Potential Years of Life Lost by Males from Treatable Causes by Province, Annually -1980 to 2010 . 60

Table 11: List of DMUs operating at Most Productive Scale Size by Measure of Life Expectancy ..... 61

Table 12: Variable Importance for CART Models examining Gender Separated Life Expectancy at Birth

Table 13: Variable Importance for CART Model examining Gender Separated Life Expectancy at Age 65

Table 14: Instances of Scale Inefficiency by Province and Category of Life Expectancy Estimate 64

Table 15: Scale Inefficient Provinces by Year - Female Life Expectancy at Birth and age 65. 64

Table 16: Scale Inefficient Provinces by Year - Male Life Expectancy at Birth and age 65 65

Table 17: Deaths from Treatable Causes MARS Model Variable Importance 67

Table 18: Variable interactions for MARS Models examining FPYLL and MPYLL 68

Table 19: Model Performance Measures of MARS Models Examining Deaths from Treatable Causes ... 68

Table 20: Male and Female Infant Mortality MARS Model Variable Importance 69 
Table 21: Variable Interactions for MARS Models Examining Infant Mortality.

Table 22: Model Performance Measures of MARS Models Examining Infant Mortality ......................... 70

Table 23: Female Life Expectancy at Birth by Province - 1980 versus 2007 ....................................... 77

Table 24: Increase in Total Per Capita Healthcare Spending by Province -1980 versus 2007................ 77

Table 25: Male Life Expectancy at age 65 and Per Capita Healthcare Spending, Prince Edward Island, 1991

Table 26: Male Life Expectancy at age 65 and Per Capita Healthcare Spending, Prince Edward Island, 1991

Table 27: R-Squared Statistics of Multivariate Adaptive Regression Splines Models 93

\section{List of Figures}

Figure 1: Diagram of the neoclassical production function.

Figure 2: Graphic example of DMUs and envelopment surfaces

Figure 3: Visualization of a Decision Tree

Figure 4: Graph of MARS model

Figure 5: Logic Model of DEA Scale Efficiency Analysis

\section{List of Appendices}

Appendix A - Summary Statistics: Health Spending by Province.

Appendix B - Summary Statistics: Health Outcomes

Appendix C - MARS Models from Analyses of Infant Mortality \& Deaths from Treatable Causes 156 


\section{Introduction}

Improving healthcare delivery while containing costs is a major issue in many developed countries (Chatal, André, Joumard, \& Nicq, 2008; Nam, Kongsrud, Joumard, \& Price, 2004; Nicq, Joumard, \& André, 2010; Or, 2000, 2001; Worthington, 2004). Since the creation of its universal healthcare program, Canada has managed the goal of providing universal coverage to citizens as costs have continued to rise over time. The Canadian Institute for Health Information reports that, as a percentage of gross domestic product, health spending has grown from $5.4 \%$ in 1960 to more than $10 \%$ in 2015 (that is $\$ 4,569$ per person in 2015 dollars) (CIHI, 2015a; Inglehart, 2000). The policy changes which have structured the Canadian health system paint the picture of the importance of health spending and costs in the country.

The narrative of Canada's public healthcare system can be segmented into three acts: the program's founding, the implementation of the Canada Health Act within the era of incremental funding cuts, and the modern era of incremental, progressive reform. The foundation of Canada's healthcare system occurred in 1957 with the federal legislation of hospital care and related diagnostic services with medical insurance being added in 1968 (Inglehart, 2000). By 1971 all provinces and territories were participating in the program in which they received federal cash transfers for agreeing to provide universal coverage (Inglehart, 2000; Naylor, 1999).

In the late 1970 s a combination of price inflation, caps on fee increases, and growth in the supply of physicians in urban markets combined to reduce doctors' real income. Some 
doctors responded to these conditions by charging patients beyond the government negotiated fee schedule. The Canadian Health Act was implemented in 1984 in major part to prohibit supplemental fees through a stipulation in which federal transfers would be reduced to provinces that allowed them, as well as to consolidate previous healthcare policy pieces (Inglehart, 2000; Naylor, 1999). Within two years all provinces abolished supplemental/nonnegotiated medical fees, creating the economic characteristics which define the healthcare system to this day; monopsonistic (single-buyer) publicly financed health insurance with private model fee-for-service care provision (Hutchison, Levesque, Strumpf, \& Coyle, 2011; Naylor, 1999).

While the era of financial austerity can be defined separately from that of the establishment of the Canada Health Act, in policy terms they began concurrently. The change in federal contributions to healthcare financing began in 1977 with a shift in the 50/50 cost sharing scheme between the federal and provincial governments. This left the provinces carrying a larger segment of health costs if those costs grew more rapidly than the size of the overall economy.

Though the budget cuts and financing rearrangements of the late 70 s were an incremental step meant to regulate medical spending, reductions continued into the 80 s that were intended to reverse the trend of ongoing government budget deficits. The economic recession of the early 90 s also warranted continued reductions in spending at both the federal and provincial levels. 
It is claimed that there were several negative effects of this era (Hutchison et al., 2011; Inglehart, 2000; Naylor, 1999). These include a reduced number of Canadian medical and nursing school enrolments, the conversion of many full-time nursing positions to part-time or on-call between 1993 and 1997, restricted purchasing of medical equipment, and a reduction in hospital beds due to the amalgamation and closing of facilities. These issues contributed to reduced public opinion concerning the quality of and satisfaction with the nation's healthcare system.

These conditions, combined with the emergence of a significant budget surplus at the end of the 90s set the correct political climate for progressive policy reform. In 2000 the First Ministers of Canada established an $\$ 800$ million Primary Care Transition Fund for healthcare reform. An additional \$16 billion federal investment was earmarked for primary healthcare, home care, and catastrophic drug coverage in the 2003 First Ministers Health Accord.

Since then, several policy initiatives have occurred in multiple jurisdictions across the country. These include:

"inter-professional primary healthcare teams, group practices and networks, patient enrollment with a primary care provider, financial incentives and blended-payment schemes, primary healthcare governance, expansion of the primary healthcare provider pool, implementation of electronic records, and quality improvement training and support."

(Hutchison et al., 2011, p. 264).

Based on this recount it would appear that, as a function of the public, single-payer model, economic policy has played a pivotal role in the narrative of Canada's healthcare 
system. Hutchison et al. (2011) argue that the recent provincial health reform efforts showing the most success have required high amounts of financial investment. Therefore the quantitative analysis of health funding allocation is important to deciding the optimal distribution of limited resources. In this thesis I offer a method for determining the efficiency of the healthcare spending in Canada's provinces and also define the categories of healthcare spending which are most significant to determining the production of health outcomes in Canada.

\subsection{The Scope of This Research}

This research empirically analyzes health outcomes as a function of nine categories of per capita healthcare spending using thirty years of data from Canada's ten provinces. All variables in the analysis are standardized and spending is specifically in 2015 dollars. The categories of healthcare spending are spending on hospital, institutions, physicians, other professionals, drugs, capital, public health, administration, and other spending.

The first phase of the analysis is separated into two parts. Part one models longevity (gender separated life expectancy at birth and life expectancy at age 65) as a function of the nine categories of health spending. This phase focuses on scale efficiency and resource allocation using data envelopment analysis and decision tree induction.

Phase two uses identical procedures to model infant mortality (gender separated number of infant deaths) and death from treatable causes (potential years of life lost due to deaths from treatable causes). Phase two focuses solely on resource allocation using multivariate 
adaptive regression splines. Overall, the results of the analysis provide evidence on which categories of healthcare spending are most influential in determining the observed levels of the separate measures of health outcomes.

\subsection{Research Approach}

This study is causal research using statistical techniques to examine longitudinal data and explore the relationships between separate categories of healthcare spending and different measures of population health. This is inductive research which makes inferences based on an examination of correlations between the observed values of independent and dependent variables. This inductive framework is approached by defining a production function in which each category of healthcare spending operates as a factor of production while the individual measures of health outcomes function as outputs. Multivariate regression analysis reveals relationships between spending and health outcomes, while a technical efficiency analysis provides a framework for comparing the performance of each of the provinces. The specific methods used in this process are multivariate adaptive regression splines (MARS), decision tree induction, and data envelopment analysis (DEA).

\subsection{Research Goals}

The goal of this research is to analyze the patterns of healthcare spending in Canada's provinces for two reasons. The first is to provide evidence as to which provinces have been 
most efficient in their allocation of funding. The second is to determine which categories of healthcare spending should be prioritized in improving specific health outcomes.

Based on this, the overarching research questions are

1. "How effectively have Canada's provinces spent their healthcare funding?" and

2. "How should spending be prioritized in order to improve health outcomes?"

The results yielded from answering the first research question provide a framework that allows the second question to be interrogated as well.

\subsection{Thesis Format}

This thesis is formatted into seven chapters. Chapter Two is a literature review examining evidence-based decision making, data analytics, and the application of analytics techniques to the healthcare context. Chapter Three outlines the theoretical framework used to approach the research, the research methods used in the analysis and a description of the data being analysed. Chapters Five and Six contain the empirical analysis and the discussion of findings respectively. The thesis is then concluded in Chapter Seven with a discussion of the limitations and contributions of the research effort. 


\section{Literature Review}

This literature review examines the study of the economic production of health outcomes through the application of growth accounting theory. These type of studies have a set of commonly used measures of performance which are applicable to healthcare systems. According to Worthington (2004), economists have developed three measures efficiency for use in the analysis of health system performance. Technical efficiency refers to the use of resources in the most productive manner. With regard to the healthcare context, technical efficiency is used to describe the relationship between healthcare resources (e.g. finances, staff, and equipment) and observable health outcomes. Allocative efficiency refers to the combination of specific proportions of resources that are used to achieve technical efficiency. At the hospital level, this could be explained as the mix of staff, equipment, and drugs used to efficiently treat patients. Productive efficiency is a measure of the combination of both technical and allocative efficiency. Productive efficiency is limited by the extent to which allocative and technical efficiency are maximized and therefore technical and allocative efficiency must be maximised to achieve maximum productive efficiency.

In terms of early applications of growth accounting theory to health production, Grossman (1972) provides a health production function for estimating health outcomes based on an individual's investment in their own health. In this model, investment in health is a function of medical care, time spent investing in health, and education. Grossman's (1972) 
claim is that the purpose of an individual investing in their health is to produce time spent in good health.

The literature examining the production of healthcare outcomes argues that the estimation of the performance of healthcare systems using technical methods is often undertaken, but is also not a simple task. Gravelle \& Backhouse (1987) offer a macroeconomic approach to the study of health production. The authors dissect the production function approach used in studies of mortality rates using international data with the goal of demonstrating the difficulty of such analyses. Their findings confirm the validity of the approach but also emphasize that the estimation of the influences on mortality using production functions is not a simple task. The authors claim that at the international level, aggregated data may complicate analyses due to differences in data quality and missing data. This applies to data on health service provision and environmental variables. Regardless of the difficulty, there are several examples of studies which attempt to define the relationship between health spending and other inputs and health outcomes using production functions.

I proceed to first explain the relevant concepts within the theory of growth accounting and productivity. I then discuss examples of studies which apply growth accounting theory to study the production of health outcomes (internationally and within Canada). After this, I specify the health production function that will be used in this thesis. 


\subsection{Growth Accounting and Production Functions}

The primary theoretical framework used in the study of health production is the economic theory of growth accounting as introduced by Robert Solow (1956). Applications of growth accounting are used to explain the relationship between factors of production (e.g. the classical inputs land, labor, and capital) and the productivity and growth (i.e. improvements in the creation of output) of economies. To elaborate, an economy is any system defined by the consumption of inputs and production of outputs within it. Growth accounting is concerned with the mathematical explanation of how the factors of production in an economy are used to modify that economy's productive abilities.

The basic model of growth accounting takes the form of the neoclassical production function which is defined mathematically as $Y=f(A, K, L)$. Figure 1 depicts a graphical representation of the neoclassical production function. In this relation, output ( $\mathrm{Y}$ ) is a function of a combination of the inputs total factor productivity/technology (A), labour (L) and capital (K). Here, technology is used to broadly capture all processes (i.e. methods and techniques) and factors (i.e. knowledge, etc.) that influence the transformation of inputs to outputs. Broadly, capital can be understood as the wealth and physical resources that are consumed in the production of output, while labour can be understood as the physical work that is performed by persons during production.

The Cobb-Douglas production function is a form of the neoclassical production function that allows the equation to be applied to additional situations. (Cobb \& Douglas, 1928). The Cobb-Douglas production function is defined as $Y=A L^{\alpha} K^{\beta}$. The terms $\alpha$ and $\beta$ correspond with 
the level of elasticity (i.e. the sensitivity to change) of labour and capital respectively. The usefulness of the Cobb-Douglas function come from the inclusion of these measures of elasticity as they facilitate an analysis of returns to scale. In other words, the inclusion of $\alpha$ and $\beta$ in the Cobb-Douglas function allows for an examination of how changes to inputs (labour and/or capital) affect an economy's output.

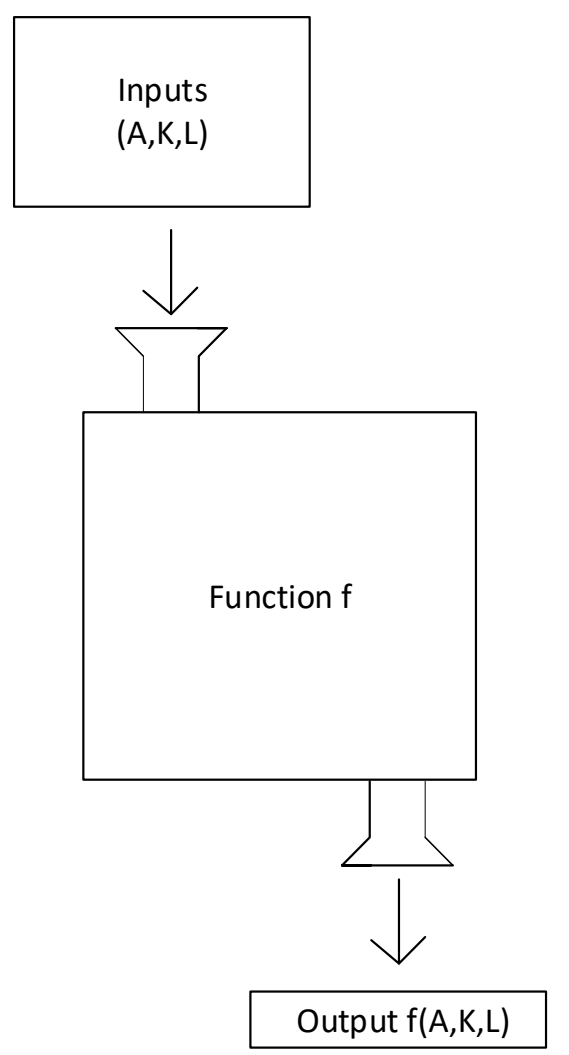

Figure 1: Diagram of the neoclassical production function

An economy's returns to scale may be decreasing, increasing or constant. In an economy operating at decreasing returns to scale (DRS), $\alpha+\beta<1$. This means that an equivalent 
increase in both inputs will correspond with an increase in output that is smaller in magnitude than the increase in inputs 1 (e.g. a 10\% increase in labour and capital generates a 5\% increase in output). Likewise, in an economy operating at increasing returns to scale (IRS) $\alpha+\beta>1$, and an equivalent increase in both inputs will correspond with an increase in output that is greater in magnitude than the increase inputs. An economy operates at constant returns to scale (CRS) when $\alpha+\beta=1$ meaning that an increase in both inputs will correspond with a proportionate increase in output. The next section discusses the application of growth accounting theory to the study of the economic production of health outcomes.

\subsection{The Study of Health Production}

There is a significant body of literature which has explored the production of health outcomes and the factors which determine the efficiency and productivity of health systems. (Chatal et al., 2008; Hollingsworth, 2003, 2008; Hollingsworth, Dawson, \& Manidakis, 1999; Worthington, 2004). At the macro level, cross-country analyses have been performed to examine the efficiency of health spending, and the monetary and contextual influencers on health outcomes (Chatal et al., 2008; Joumard \& Häkkinen, 2007; Nicq et al., 2010). Comparative analyses have taken place in multiple instances examining different jurisdictional levels (both within and across nations) and utilizing both cross-sectional and longitudinal data to interrogate the determinants of health (Berger \& Messer, 2002; Chatal et al., 2008; Nixon \& Ulmann, 2006; Retzlaff-Roberts, Chang, \& Rubin, 2004). 
Elola, Daponte, \& Navarro (1995) perform a comparative analysis relating different health system models (social security versus national health service) to health indicators (gender separated potential years of life lost, gender separated life expectancy, and infant mortality) in 17 countries in Western Europe. The results of their regression analysis indicate that, in both types of health systems, spending was inversely correlated with potential years of life lost for females and infant mortality rates. They also claim that spending was positively correlated with life expectancy. The authors conclude that increases in health spending as a percentage of GDP would decrease infant mortality rates more efficiently in countries with a national health service than in countries using social security systems.

Or (2000) develops a health production function to examine the differences in the health outcomes within 21 OECD member nations using data from between the years 1970 and 1992. In the regression analysis, health outcomes (i.e. potential years of life lost due to all causes except suicides) are modeled as a function of medical variables (total health expenditure per capita, share of public health spending, gross domestic product) and non-medical variables (i.e. work force composition, pollution, consumption of alcohol, tobacco, fat and sugar). The results indicate a positive relationship between health spending and health outcomes, and the significance of environmental factors in determining health outcomes in the countries examined.

Using a regression analysis, Berger \& Messer (2002) model health outcomes (mortality rate per 1000 population) as a function of health spending, insurance coverage, health behaviors (alcohol consumption, consumption of fat, tobacco consumption), and other 
variables in 20 OECD member nations. Their results indicate that tobacco use, alcohol use, fat consumption, and female labor force participation are all significantly related to mortality rates. Interestingly the authors also conclude that higher income inequality leads to lower mortality rates, and that increases in public health spending also lead to increased mortality rates.

Retzlaff-Roberts et al. (2004) perform a comparative, technical efficiency analysis of the relationship between spending and the production of life expectancy and infant mortality in several OECD member nations. Using both input and output oriented models of data envelopment analysis, the authors attempted to determine which of the 27 countries included was performing at the highest level of technical efficiency. The analysis revealed that while some of the countries were outperforming others in the efficiency of healthcare spending and their ability to generate positive health outcomes, the nations which performed moderately in the production of health outcomes were still achieving technically efficiency in their spending.

Nixon \& Ulmann (2006) use a log-linear production function to study health outcomes in 15 members of the European Union. The authors highlight the micro and macro level approaches to the production functions that are used in studying the relationship between health spending and contextual factors (e.g. diet, lifestyle, economic status), and health outcomes; electing to perform a macro-level analysis of 16 years of aggregated data. Their results confirm previous findings that since the 1980 s increased healthcare spending has had a reduced impact on improving health outcomes in developed countries. In contrast, they also note that increased health spending has contributed to lowering infant mortality rates. 
Joumard \& Häkkinen (2007) define a theoretical framework for the evaluation of health production in OECD member nations. The authors also provide three approaches and to implementing this framework depending on the analysis being undertaken and the availability of data. The approaches are the aggregate/system level approach, the disease level approach and the subsector level approach (i.e. hospital, outpatient care, nursing homes etc.).

The authors argue that while the scope of each approach distinguishes them from one another, data availability is a primary limiting factor in these types of analyses. This leads to the claim that while the commonly used indicators of health status are not the best (i.e. life expectancy), they are used because they are more widely captured than more optimal indicators. Figure 2 illustrates the theoretical model proposed by Joumard \& Häkkinen (2007).

Chatal et al. (2008) develop a health production function to examine the monetary and contextual determinants of health status in the OECD area using both data envelopment analysis and panel data regression. The variables examined include contextual variables (tobacco consumption, alcohol consumption, diet, air pollution, education) and economic variables (health care resources per capita and gross domestic product per capita). In this work, it is acknowledged that the contribution of private spending to healthcare outcomes is both significant and extremely difficult to disentangle from public sector spending in these types of analyses. The results of the regression analysis reinforce logical assumptions on the correlations between smoking, alcohol consumption, diet, pollution, education and GDP with health outcomes. Additionally, the data envelopment analysis results reveal that increases in spending efficiency are likely to significantly contribute to increased life expectancy among OECD 
member nations. Nicq et al. (2010) present indicators for use in a cross-country health system level analysis based on the goals of raising population health status and improving equity in access. The authors adopt the theoretical model first proposed by Joumard \& Häkkinen (2007). Using data envelopment analysis, the authors measure the efficiency of health care delivery across several OECD member nations in a production function that relates health inputs in terms of financial resources to health outcomes. The results of the study indicate that an increase in the absolute amount of spending would cause negligible changes in life expectancy without improvements in the efficiency of spending. I now move on to discussing these types of analysis as performed using data from the Canadian health system.

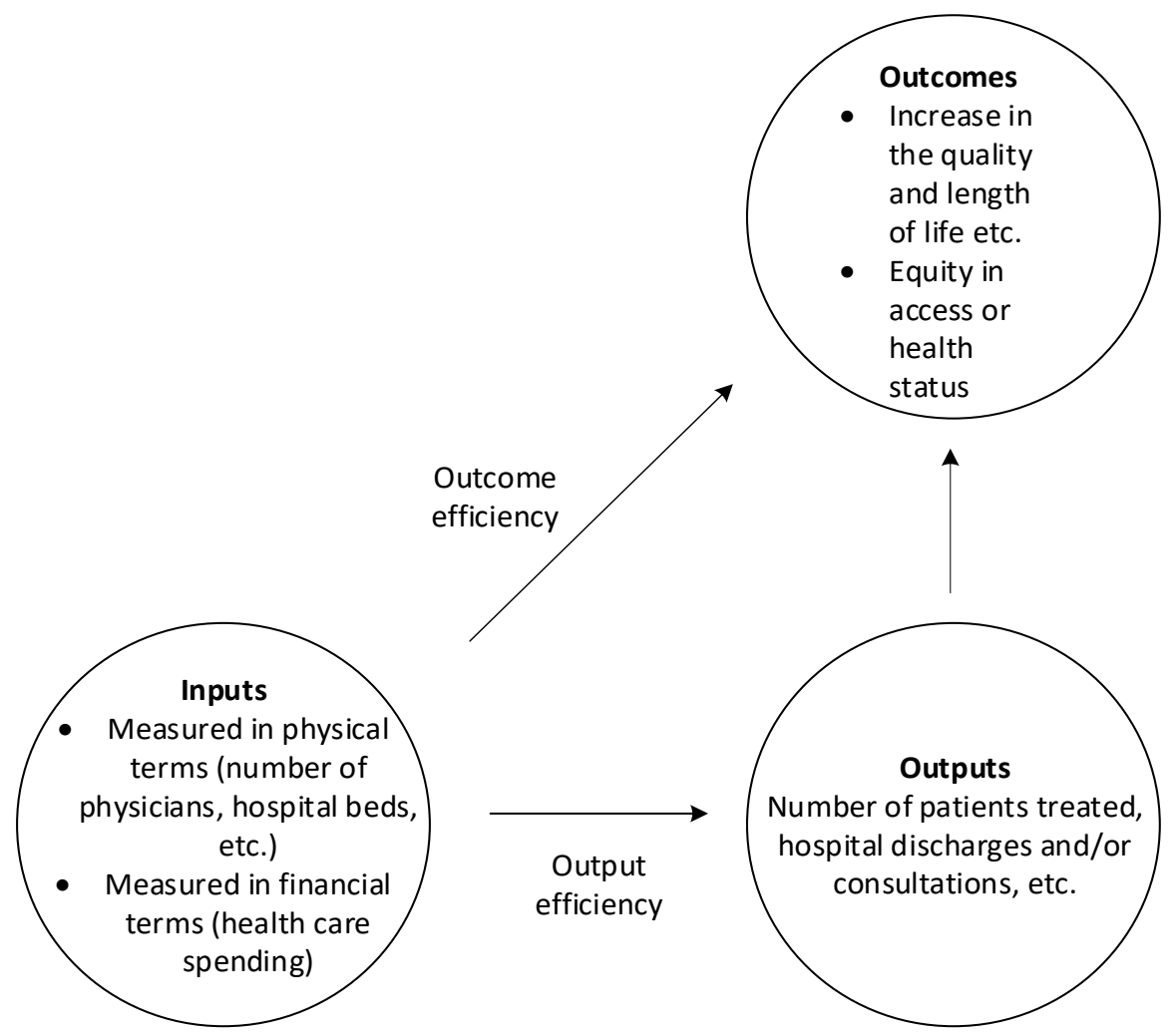

Figure 2: Framework of health efficiency measurement by Hakkinen \& Joumard. 


\subsection{Canadian Context}

Hanratty (1996) performs an analysis of the impact of national health insurance in Canada on infant health. The author uses panel data from 1960-1975 in regression models model outcomes as a function of the timing of the program's introduction across the country. The results link the implementation of national health insurance to improvements in the country's infant health measures.

At the provincial level, Crémieux, Ouellette, \& Pilon, (1999) model gender-separated infant mortality and life expectancies as functions of spending, demographic, lifestyle, nutrition and province specific characteristics in a regression that uses pooled time-series cross-section data from 1978 to 1992 . The results indicate that lower healthcare spending is correlated with increases infant mortality and decreases in life expectancy. The authors argue that their findings are strengthened by the homogeneity of their data. This claim is made in comparison to analyses performed using heterogeneous cross-country data which were unable to find strong correlations between health spending and health outcomes.

Bilodeau, Crémieux, Jaumard, Ouellette, \& Vovor (2004) perform data envelopment analysis to measure the technical efficiency of hospitals in Québec. They specify a function that includes both discretionary and nondiscretionary inputs; meaning inputs that are within the control of the hospitals (discretionary) and those that are not (nondiscretionary). This is done to reduce bias created by missing variables. Their results indicate that there observed inefficiencies was attributable to differences in management and quality of care between hospitals. 
Crémieux et al. (2005) use a regression model that focuses on the contributions of nondrug spending, pharmaceutical spending (public and private), and contextual variables (population density, poverty, per capita income, alcohol consumption, tobacco consumption, food and non-alcoholic beverage consumption). This analysis examines data from the years 1981 to 1988 in five regions of Canada (the Atlantic Provinces, Quebec, Ontario, the Prairies and British Columbia). The results indicate a strong relationship between increased public and private drug spending and improvements in infant mortality and life expectancy.

Day \& Tousignant (2005) contribute a review of the academic literature which uses the production function method to examine the determinants of health status in Canada. The authors also discuss some of the problems that apply to performing this type of analysis at the cross-country level as discussed by Gravelle \& Backhouse (1987). Of specific interest to this research are the problems of deciding on a measure (or measures) of health status, obtaining data on the inputs used to produce health, and the specification of the health production function's form. Day \& Tousignant (2005) also argue that there are not many examinations of the Canadian healthcare system performed using the methods discussed above.

\subsection{Summary of Literature Review}

In this review of literature I introduced important concepts to the economic study of health outcomes. I first explain the theory of growth accounting and then identified several examples of papers that apply this theory to create production functions that explore the relationship between health spending and other relevant variables, and health outcomes. There 
are several examples of these papers in the international context which confirm that public and private spending on health care are important determinants of health outcomes. Canadian studies using more homogenous data have confirmed this relationship as well. Additionally, international studies have evaluated the effectiveness with which healthcare spending has contributed to health outcomes in terms of efficiency.

Based on these findings, this thesis will contribute an evaluation of the efficiency of health spending in Canada. Additionally, a gap in the literature appears to exist in terms of studies that identify how healthcare spending should be prioritized. That is there is a lack of research that directly discusses which components of overall healthcare spending are most important to determining health outcomes. In response, this thesis will examine the question of how healthcare spending should be prioritized. 


\section{Methods and Data}

The study of health production relies on statistical techniques which apply growth accounting theory to examine the relationship between health spending and non-spending inputs, and the production of health outcomes. In this thesis, I focus on health spending and apply statistical techniques with two goals: to provide evidence as to which of Canada's provinces have been most efficient in their allocation of funding, and to determine which categories of healthcare spending should be prioritized in improving specific health outcomes. To achieve these goals I ask two research questions:

1. "How effectively have Canada's provinces spent their healthcare funding?" and

2. "How should spending be prioritized in order to improve health outcomes?"

These research questions are answered in two steps:

1. Specifying and applying a model for determining the efficiency of the healthcare spending in Canada's provinces;

2. Defining the categories of healthcare spending which are most significant to determining the production of health outcomes in Canada's provinces;

This chapter describes the techniques and dataset used to complete this analysis. Next I specify the health production function for use in this thesis. 


\subsection{Defining a Health Production Function}

I now specify define a production function which relates healthcare spending to healthcare outcomes (Chatal et al., 2008; Or, 2000). This thesis uses a production function adapted from work performed by Chatal et al. (2008) to examine OECD member nations. Additionally, I adopt a modified definition of health outcomes provided by Joumard \& Häkkinen (2007). In the original definition health outcomes are "changes in health status of the population which can be attributed to public spending on healthcare" (Joumard \& Häkkinen, 2007, p. 5). For the purpose of this thesis I have included both private and public healthcare spending contributions in the analysis. This has been done to account for the non-negligible contribution of private healthcare expenditure in Canada (Chatal et al., 2008; CIHI, 2015b; Crémieux et al., 2005).

The health outcomes examined in this analysis are life expectancy at birth, life expectancy at age 65, Deaths from treatable causes, and infant mortality. Each outcome measure has been gender separated. This raises the total number of models examined to eight. All eight models consider nine inputs, each representing a separate category of healthcare spending. The function is specified as follows:

$$
\begin{gathered}
\mathrm{Y}_{\text {it }}=\beta_{0}+\beta_{1} \cdot \text { HOSP }_{\text {it }}+\beta_{2} \cdot \text { INST }_{\text {it }}+\beta_{3} \cdot \text { PHYS }_{\text {it }}+\beta_{4} \cdot \text { OPRO }_{\text {it }}+\beta_{5} \cdot \text { DRUG }_{\text {it }}+\beta_{6} \cdot \text { CAPT }_{\text {it }} \\
+\beta_{7} \cdot \text { PUBH }_{\text {it }}+\beta_{8} \cdot \text { ADMN }_{\text {it }}+\beta_{9} \cdot \text { OTHR }_{i t}+\varepsilon
\end{gathered}
$$

Where $Y_{i t}$ (output) is a measure of population health in province $i$, year $t$. In each model Y corresponds with either:

- Life expectancy at birth (LEB) 
- Life expectancy at age 65 (LE65)

- Potential Years of Life Lost Due to Deaths from Treatable Causes (PYLLTC)

- Infant mortality measured in Number of Infant Deaths per year

The inputs are defined as per capita spending on hospitals (HOSP), other institutions (INST), physicians (PHYS), other professionals (OPRO), drugs (DRUG), health capital (CAPT), public health (PUBH), administration (ADMN), and other spending (OTHR). All spending values have been standardized to their value in 2015 dollars. This model allows for the decomposition of the relationship between health spending and the health outcomes specified above. This model does not control for non-spending contextual the variables that are often examined in studies which evaluate the health. A full description of the sources of data in this thesis will be given in a later point of this chapter. Moving on, I describe the techniques applied in this research.

\subsection{Methods}

The methods used in this study have been selected for their usefulness in applying the established growth accounting framework and their validity as applied data analytics techniques. These methods facilitate a quantitative, longitudinal examination, allowing for an explanation of how each category of health spending has influenced population health outcomes. The methods used in this study include Data Envelopment Analysis, decision trees, and multivariate adaptive regression splines. The next section discusses the details of DEA. 


\subsubsection{Data Envelopment Analysis}

Data envelopment analysis (DEA) is a statistical method for evaluating the technical efficiency of a set of similar economies or production units. A DMU is conceptually equivalent to an economy or production unit that consumes input(s) to create output(s). When applying DEA to a set of DMUs, all of the DMUs are evaluated comparatively to reveal which are the most efficient. The method can be applied in a wide variety of contexts as demonstrated throughout the efficiency measurement literature, including the study of health systems and the production of health. This is because applying DEA does not require previous knowledge on the factors which affect production processes that the DMUs represent (Coelli \& Coelli, 2005; Cooper, Seiford, \& Zhu, 2010; Hollingsworth et al., 1999).

While methods of regression focus on creating a function which defines the central tendency (i.e. average behaviour) of observations, DEA is an extreme point method. This mean that it focuses on creating a spline (a linear mathematical function) that defines the most technically efficient production processes observed (Cooper et al., 2010).

It is important to understand that technical efficiency is a context specific interpretation of efficiency. When a DMU is determined to be technically efficient in a single application of DEA this is based on its performance relative to the other DMUs included in the analysis. A DMU that is technically efficient in one analysis will is not necessarily efficient in general. Also, the DMUs which are selected as technical efficient in an application of DEA are the units who cannot improve their performance beyond what they have already achieved. This is based on the criteria that a technically efficient DMU cannot increase its productive ability by modifying 
the consumption of any of its inputs or outputs without modifying the consumption any of its other inputs or outputs.

The basic mathematical model for DEA is based on an extension of the work of Farrell (1957) and is named the CCR model after its developers Charnes, Cooper and Rhodes (1978). Farrell was originally attempting to improve upon previous productivity measurement methods that were restrictive and ineffective at measuring the combination of multiple inputs into multiple outputs.

In DEA we assume that $\mathrm{DMU}_{\mathrm{j}}$ consumes $\mathrm{x}_{\mathrm{ij}}$ amounts of input $\mathrm{i}$ and produces $\mathrm{y}_{\mathrm{rj}}$ amount of output $r$. We also assume $x_{i j} \geq 0$ and that $y_{r j} \geq 0$ and also assume that each DMU has at least one positive input value and at least one positive output value.

The CCR DEA model measures the relative efficiency of $\mathrm{DMU}_{\mathrm{j}}=\mathrm{DMU}_{\mathrm{o}}$ by using a ratio of all its observed inputs and outputs. The CCR model simplifies this by combining the multiple outputs and inputs of a DMU into one "virtual" output and one "virtual" input. This ratio of output to input provides a measure of efficiency which is a function of the multipliers $u_{r}$ and $v_{i}$ and is maximized. Mathematically this equation can be stated as follows:

$$
\operatorname{Max} h_{\mathrm{o}}(\mathrm{u}, \mathrm{v})=\sum_{\mathrm{o}} \mathrm{u}_{\mathrm{r}} \mathrm{y}_{\mathrm{ro}} / \sum_{\mathrm{o}} \mathrm{v}_{\mathrm{i}} \mathrm{x}_{\mathrm{io}}
$$

Where

- $\quad u_{r}$ corresponds with observed output,

- $\quad v_{i}$ corresponds with the observed input, 
- $\quad y_{\text {ro }}$ represents the observed amount y of output $r$ produced by $D M U_{0}$ from the input amount $x_{\text {io }}$

- $\quad$ and $x_{i o}$ is the observed amount of input $\mathrm{i}$ consumed in order to produce $y$ amount of output $r$ by the $\mathrm{DMU}_{\text {o }}$

- $\mathrm{DMU}_{\mathrm{o}}$ is the $\mathrm{DMU}$ being evaluated

A full development of the CCR model replaces $u_{r}, v_{i} \geq 0$ with $\frac{u_{r}}{\sum_{i=1}^{m} v_{i} x_{i o}}, \frac{v_{r}}{\sum_{i=1}^{m} v_{i} x_{i o}} \geq \varepsilon>0$ where $\varepsilon$ is a non-Archimedean element smaller than any positive real number. This transformation guarantees a positive solution in the variables but also gives an infinite number of solutions. The Charnes and Cooper (1962) transformation, developed by the authors after which it is named, is used to select a single solution and changes the variables $(u, v)$ to $(\mu, v)$

$$
\max \mathrm{z}=\sum_{\mathrm{r}=1}^{\mathrm{s}} \mu_{\mathrm{r}} \mathrm{y}_{\mathrm{ro}}
$$

subject to

$$
\begin{gathered}
\max z=\sum_{r=1}^{s} \mu_{r} y_{r j}-\sum_{i=1}^{m} v_{i} x_{i j} \leq 0 \\
\sum_{i=1}^{m} v_{i} y_{r j}=1 \\
\mu_{r} v_{i} \geq 0 .
\end{gathered}
$$

The Farrel model is the corresponding linear programming model and is defined as follows: 


$$
\theta^{*}=\min \theta
$$

Subject to

$$
\begin{aligned}
& \sum_{j=1}^{n} x_{i j} \lambda_{j} \leq \theta x_{i o} i=1,2, \ldots, m ; \\
& \sum_{j=1}^{n} y_{r j} \lambda_{j} \leq \theta y_{r o} r=1,2, \ldots, s ; \\
& \lambda_{j} \geq 0 \quad j=1,2, \ldots, n .
\end{aligned}
$$

Where $\theta^{*}$ is the efficiency score for a particular DMU. This equation ignores non-zero slacks (left over inputs), meaning that any DMUs it deems to be efficient $\left(\theta^{*}=1\right)$ are by definition weakly efficient. A strongly efficient DMU will have both an efficiency score equal to one and slacks equal to zero. In order to address the issue of non-zero slacks, the following linear programming model can be used.

$$
\max \sum_{\mathrm{i}=1}^{\mathrm{m}} \mathrm{s}_{\mathrm{i}}^{-}+\sum_{\mathrm{r}=1}^{\mathrm{s}} \mathrm{s}_{\mathrm{r}}^{+}
$$

Subject to

$$
\begin{gathered}
\sum_{j=1}^{n} x_{i j} \lambda_{j}+s_{i}^{-}=\theta^{*} x_{i o} i=1,2, \ldots, m ; \\
\sum_{j=1}^{n} y_{r j} \lambda_{j}+s_{r}^{+}=\theta^{*} y_{r o} r=1,2, \ldots, s ;
\end{gathered}
$$




$$
\lambda_{\mathrm{j}}, \mathrm{s}_{\mathrm{i}}^{-}, \mathrm{s}_{\mathrm{r}}^{+} \geq 0 \forall \mathrm{i}, \mathrm{j}, \mathrm{r}
$$

Where $s_{i}^{-}$and $s_{r}^{+}$are slack variables that do not affect $\theta^{*}$. The next equation demonstrates the same principles above but using a ratio of input to outputs and is minimised. This is called an output orientation.

$$
\operatorname{Min} \frac{\sum_{\mathrm{i}} \mathrm{v}_{\mathrm{i}} \mathrm{x}_{\mathrm{io}}}{\sum_{\mathrm{r}} \mathrm{u}_{\mathrm{r}} \mathrm{y}_{\mathrm{ro}}}
$$

Subject to

$$
\begin{gathered}
\frac{\sum_{\mathrm{i}} \mathrm{v}_{\mathrm{i}} \mathrm{x}_{\mathrm{ij}}}{\sum_{\mathrm{r}} \mathrm{u}_{\mathrm{r}} \mathrm{y}_{\mathrm{rj}}} \geq 1 \text { forj }=1, \ldots, \mathrm{n}, \\
\mathrm{u}_{\mathrm{r}}, \mathrm{v}_{\mathrm{i}} \geq \varepsilon>0
\end{gathered}
$$

Applying the Charnes and Cooper transformation gives

$$
\min q=\sum_{i=1}^{m} v_{i} x_{i o}
$$

Subject to

$$
\begin{gathered}
\sum_{i=1}^{m} v_{i} x_{i j}-\sum_{r=1}^{s} \mu_{r} y_{r j} \geq 0 \\
\sum_{r=1}^{s} \mu_{r} y_{r o}=1 \\
\mu_{r}, v_{i} \geq \varepsilon \forall r, i
\end{gathered}
$$




$$
\max \varphi+\varepsilon\left(\sum_{\mathrm{i}=1}^{\mathrm{m}} \mathrm{s}_{\mathrm{i}}^{-}+\sum_{\mathrm{r}=1}^{\mathrm{s}} \mathrm{s}_{\mathrm{r}}^{+}\right)
$$

Subject to

$$
\begin{aligned}
& \sum_{j=1}^{n} x_{i j} \lambda_{j}+s_{i}^{-}=x_{i o} i=1,2, \ldots, m ; \\
& \sum_{j=1}^{n} y_{r j} \lambda_{j}-s_{r}^{+}=\varphi y_{r o} r=1,2, \ldots, s ; \\
& \lambda_{j} \geq 0 \quad j=1,2, \ldots, n .
\end{aligned}
$$

Here $\varphi^{*}$ represents the efficiency score of a DMU. Under this orientation, a DMU is only efficient when $\varphi^{*}=1$ and $s_{\mathrm{i}}^{-*}=\mathrm{s}_{\mathrm{r}}^{+*}=0$ for all $\mathrm{i}$ and $\mathrm{r}$ and is only weakly efficient if $\varphi^{*}=$ 1 and $\mathrm{s}_{\mathrm{i}}^{-*} \neq 0$ and/or $\mathrm{s}_{\mathrm{r}}^{+^{*}} \neq 0$. The following linear programming problem uses an output orientation as part of a two-step problem involving the previous equation. In the first step $\varphi^{*}$ is calculated while ignoring slacks. In the second step using the next equation, slacks are optimized by fixing $\varphi^{*}$.

$$
\max \sum_{\mathrm{i}=1}^{\mathrm{m}} \mathrm{s}_{\mathrm{i}}^{-}+\sum_{\mathrm{r}=1}^{\mathrm{s}} \mathrm{s}_{\mathrm{r}}^{+}
$$

Subject to

$$
\sum_{j=1}^{n} x_{i j} \lambda_{j}+s_{i}^{-}=x_{i o} i=1,2, \ldots, m \text {; }
$$




$$
\begin{gathered}
\sum_{j=1}^{n} y_{r j} \lambda_{j}-s_{r}^{+}=\varphi^{*} y_{r o} r=1,2, \ldots, s ; \\
\lambda_{j} \geq 0 j=1,2, \ldots, n .
\end{gathered}
$$

Table 1 summarizes the dual linear equations which correspond with the CCR model. By adding a constraint $\sum_{\mathrm{j}=1}^{\mathrm{n}} \lambda_{\mathrm{j}}$ they become the BCC model which adds the variable $\mu_{\mathrm{o}}$ and allows for the evaluation of returns to scale. Because of this the CCR model is known as the constant returns to scale (CRS) model and the BCC model is known as the variable returns to scale model (VRS).

Different constraints based on assumption of returns to scale can be applied in DEA. Figure 3 illustrates a set of seven DMUs, each using one input (X) to produce one output (Y). The set of which DMUs which are considered to be performing efficiently depend on what constraint is applied. This means that different efficiency scores for a single DMU may be generated based on which constraint is applied. Under the assumption that all DMUs are operating at constant returns to scale (the CCR model), U2 would be the only DMU operating efficiently. Under the constraint of variable returns to scale (BCC model) the efficient DMUs would include $\mathrm{U} 1, \mathrm{U} 2, \mathrm{U} 3$, and $\mathrm{U} 4$. Under the assumption that all DMUs are operating at constant returns to scale (the CCR model), U2 would be the only DMU operating efficiently. Under the constraint of variable returns to scale (BCC model) the efficient DMUs would include $\mathrm{U} 1, \mathrm{U} 2, \mathrm{U} 3$, and U4. 


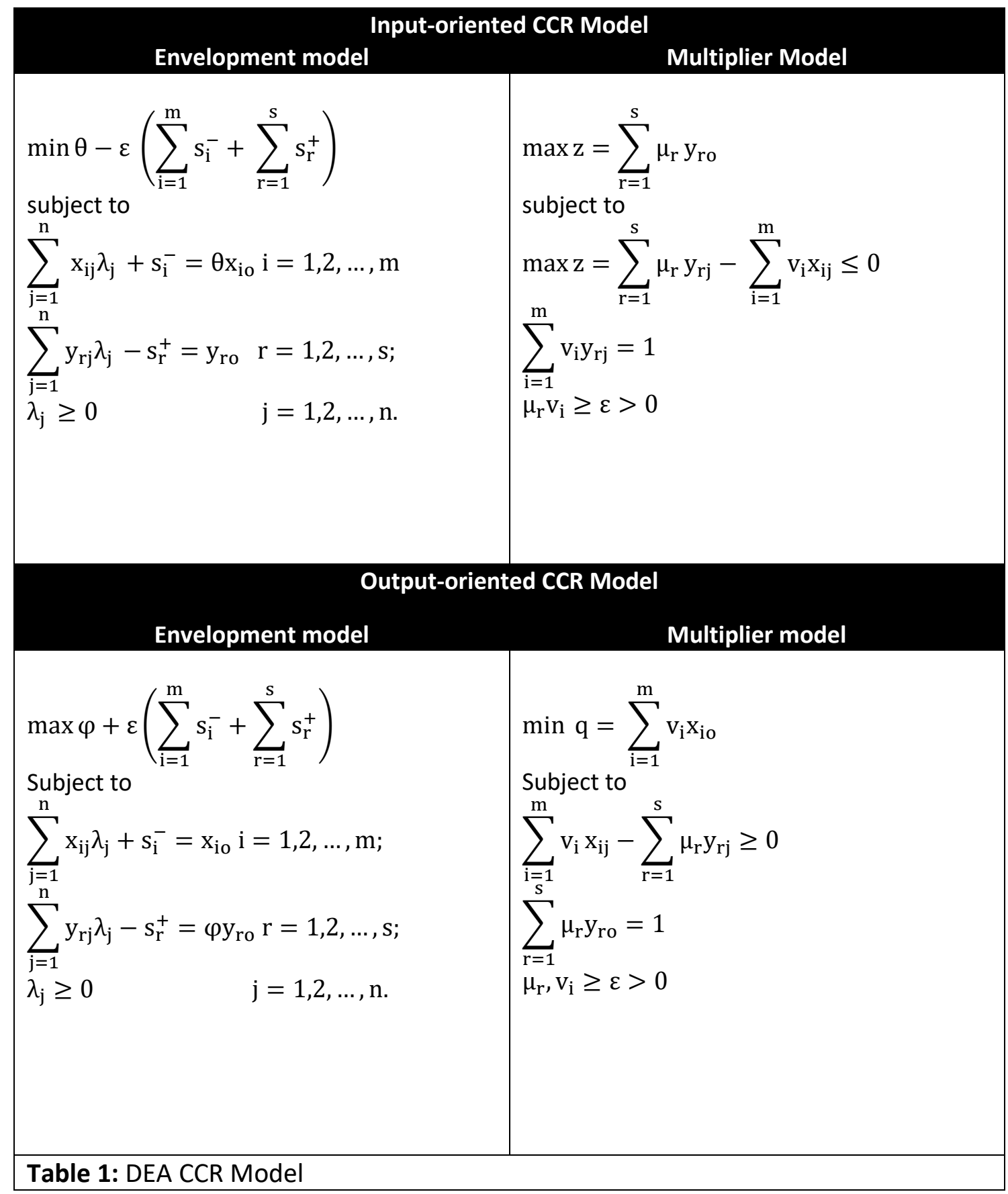

As a technique within the application of DEA, efficiency scores generated by imposing different returns to scale constraints can be used to examine returns to scale in terms of efficiency (a concept called scale efficiency). Specifically, by comparing the efficiency scores generated for a single DMU under multiple constraints, one can determine whether the DMU is 
operating at IRS, DRS or most productive scale size. When a DMU is operating at its most productive scale size within this framework, it cannot improve its productivity by modifying any of its inputs of outputs.

This is because the two different models create different envelopment surfaces based on their constraints. The envelopment surface corresponds with the set of DMUs which are deemed efficient. In the CCR model this envelopment surface consists of a line from the origin and through U2 (the red line in Figure 2). In the BCC model the envelopment surface consists of U1, U2, U3 and U4 (the blue line in Figure 2).

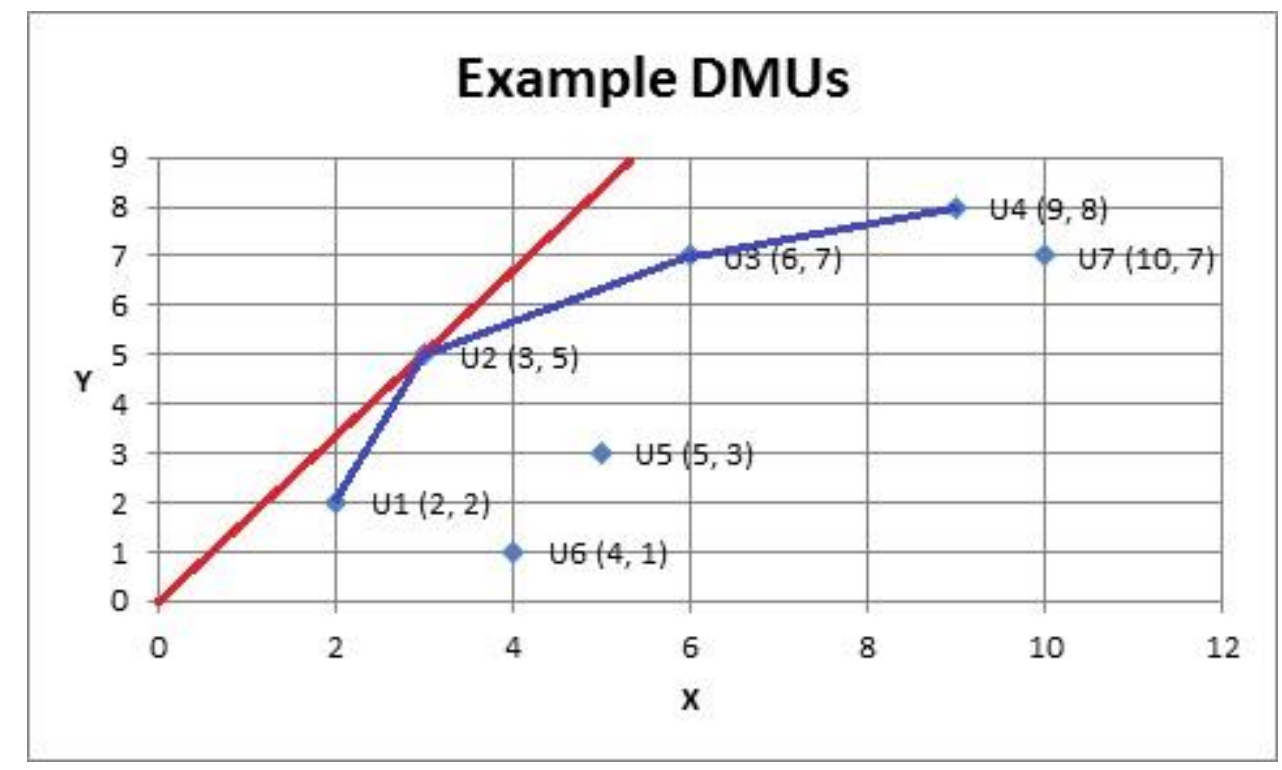

Figure 3: Graphic example of DMUs and envelopment surfaces

In addition to the constraints applied by the BCC and CCR models, the input and output orientations of DEA provide more criteria under which DMUs are evaluated. In the input orientation the goal is to minimize the use of inputs. Graphically this would represents a horizontal shift of DMUs towards the envelopment surface. Under the output orientation the 
goal is to augment output. This is graphically represented by the vertical movement of DMUs towards the envelopment surface. Ultimately, DMUs determined to be efficient in one orientation will also be efficient under the other orientation.

I will now provide a condensed summary of all of the above. First, DEA generates efficiency scores by comparing a set of decision making units (economies or production units) to each other based on their usage of resources. In the input orientation of DEA, efficient DMUs minimize their use of inputs while maintaining their output. In this orientation efficiency scores are calculated by calculating a ratio of all of a DMU's outputs to all of that DMU's inputs.

In the output orientation, the goal is to maximize output while holding input constant. In this orientation, efficiency scores are generated by calculating a ratio of a DMU's inputs to its outputs. In both orientations, an efficiency score of 1 or $100 \%$ indicates that a DMU is technically efficient. As DEA is a comparative method, it measures efficiency in a context specific sense. That is, a DMU which is deemed efficient in a DEA analysis is only efficient relative to the other DMUs included in that analysis.

As well, the type of efficiency that is measured when applying DEA is also determined by the constraint of returns to scale being imposed on the included DMUs (i.e. the DMUs may be assumed to be operating at constant returns to scale, variable returns etc.). Finally, in order for a DMU to be considered strongly efficient in DEA, it must have zero slacks, meaning it has no left over inputs. Otherwise, that DMU can only be considered weakly efficient. With these concepts established I now move on to an explanation of decision trees. 


\subsubsection{Decision Tree Induction}

Decision trees (DT) are a category of predictive induction algorithms which take their name from their visual resemblance to an inverted tree. In simpler terms, decision trees are used to describe datasets in terms of a set of rules, visualized to resemble a flow chart. Additionally, while decision trees are based on a finite amount of observed data, a decision tree can be used to make predictions outside of these observations based the rules that it composes.

Decision trees are used in the prediction of both continuous and nominal variables (Breiman, 1998; Osei-Bryson, 2014a). Figure 4 provides a visual example of a DT. The method is useful for partitioning datasets based on observed differences in the quantitative or qualitative characteristics of different parts of the dataset. When used for multiple regression, the method can also be used to provide information on the importance of its independent variables.

The first node in a decision tree is called the root node and contains all of the observations within the dataset being analysed. Each node stemming from this root node corresponds with a partition in the dataset that it analyzes. These are collectively referred to as decision nodes or leaf nodes. The terminology used to relate the leaf nodes within a decision tree is akin to that used to describe relationships in a family. A node which other nodes stem from is called a parent node, while the nodes which stem from a parent node are called child nodes. Likewise, child nodes which stem from the same parent are referred to as siblings.

Decision trees in which the splitting rules only allow for the creation of two child nodes are known as binary trees. Binary trees do not necessarily correspond with the best way to 
partition a dataset for visual interpretation, but they also do not necessarily detract from the strength or accuracy of a DT model.

A classification tree is a DT in which the target variable corresponds with nominal or categorical variables, while a regression tree is a DT in which the target variable is continuous. In a RT, each node corresponds with the mean value and standard deviation of the target variable. For both types of DT each leaf describes the logic of an "if-then" rule.

The conditions of the rule, which correspond with the value of independent variables, are denoted by the branches connecting the root of the DT to the given leaf. A DT algorithm is implemented by selecting a single target/dependent variable and multiple related predictor/independent variables.

The process of DT generation involves a Growth Phase and an optional Pruning Phase which use separate portions of the overall dataset. With large datasets the generation of a DT involves splitting the data into either two or three parts (Training and Validation or Training, Validation, and Test) to avoid over-fitting. For small datasets, cross-validation allows for the entire dataset to be used for both the Growth and Pruning Phases. These phases are both described in the next two sections. 


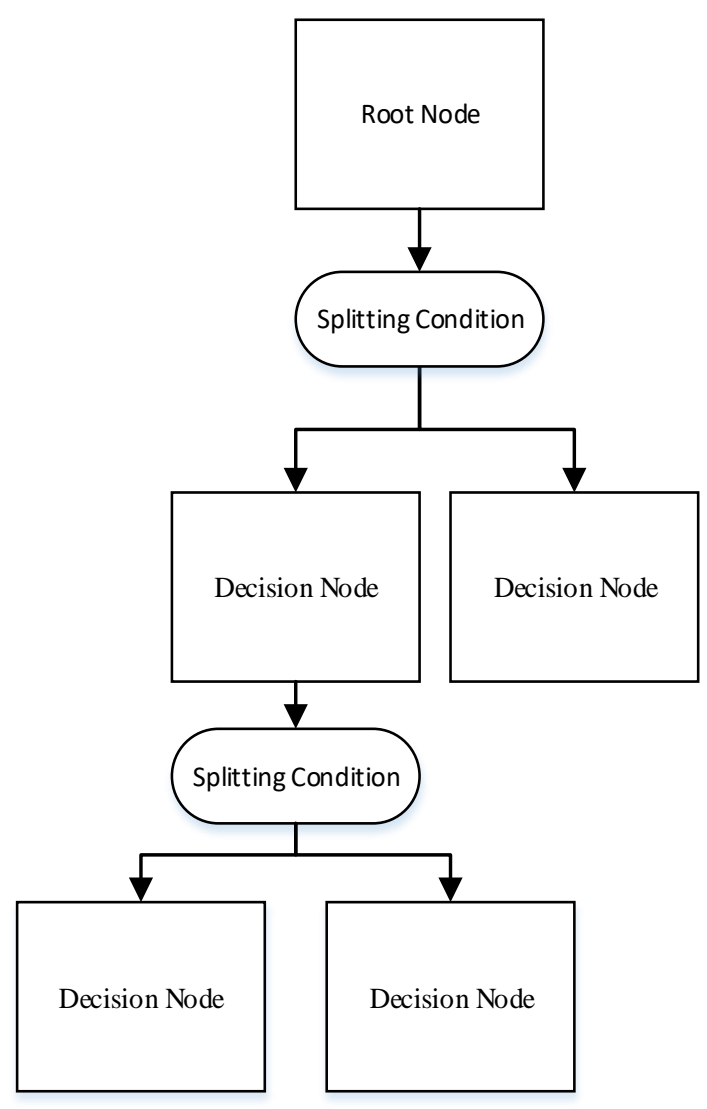

Figure 4: Visualization of a Decision Tree

\section{Growth Phase}

The Growth Phase involves generating a DT from the Training data in which each leaf node is associated with a single class, or where further division of a leaf would result in the number of observations in one or both child nodes being below a pre-specified threshold.

The Training data is continuously divided into smaller, more homogenous subsets targeting the dependent variable. The selected induction algorithm automatically decides how to divide the data by considering what variable to split, what the best split is, and when to stop splitting. 
The part of the induction algorithm which determines both the independent variables to select for a given leaf, and the values of variables used to partition leafs into mutually exclusive subsets is called the splitting method. For classification trees, these include Chi, Gini, and various entropy-based methods while for regression trees, these include variance reduction and F-test.

There is no universally optimal splitting method for the best results from a dataset as datasets vary in sensitivity to different methods. Because of this it is important to explore the effects of different splitting methods in order to obtain the best DT.

\section{Pruning Phase}

The Pruning Phase generalizes the un-pruned DT that was generated in the Growth Phase to avoid over-fitting the final DT to the training data. In this phase, the un-pruned DT is evaluated against the Validation data subset. To do this, a sub-tree is created from the unpruned DT from the Growth Phase with the lowest error rate in comparison to the Validation data, a tree that is not independent of the Training data or Validation data. Because of this, the sample distribution of observations in the Validation data must correspond with the population distribution of observations. The next section describes the Multivariate Adaptive Regression Splines technique. 


\subsubsection{Multivariate Adaptive Regression Splines}

Multivariate Adaptive Regression Splines is a technique of inductive regression analysis used for examining the causal relationships between quantitative variables. The name of the technique indicates that it is a technique for multiple regression (regression using multiple independent variables) which adapts to the data being analysed. The technique allows the dataset that it analyses to determine the form of the function it generates by creating a piecewise function over the data's decision space (the observed values of independent variables in the dataset). The method is helpful for determining which of the independent variables in a multiple regression are most useful in explaining the variation in the dependent variable, for examining interactions between independent variables, and, in larger datasets, can make these observations in the presence of missing values (Friedman, 1991; Osei-Bryson, 2014b).

\section{$\underline{\text { Regression Splines Model }}$}

The nature of a MARS regression equation is such that it is composed of multiple basis functions (BFs) smoothly connected at knots. Graphically, this appears as a piecewise polynomial functions with kinks where each basis function meets another. The behavior of a MARS function changes at each knot, and each knot is generated based on the data set being analyzed. Figure 4 provides a graphic example of a MARS model. In MARS, the relationship between a single dependent variable $X_{t}$ and independent variable $Y_{t}$ takes the form: 


$$
Y_{t}=\sum_{k=1}^{M} a_{k} B_{k}\left(X_{t}\right)+\varepsilon_{t}
$$

Where $B_{k}\left(X_{t}\right)$ is the kth basis function of $X_{t}$. Similar to linear regression, the coefficient of each basis function is estimated by minimizing the sum of square errors.

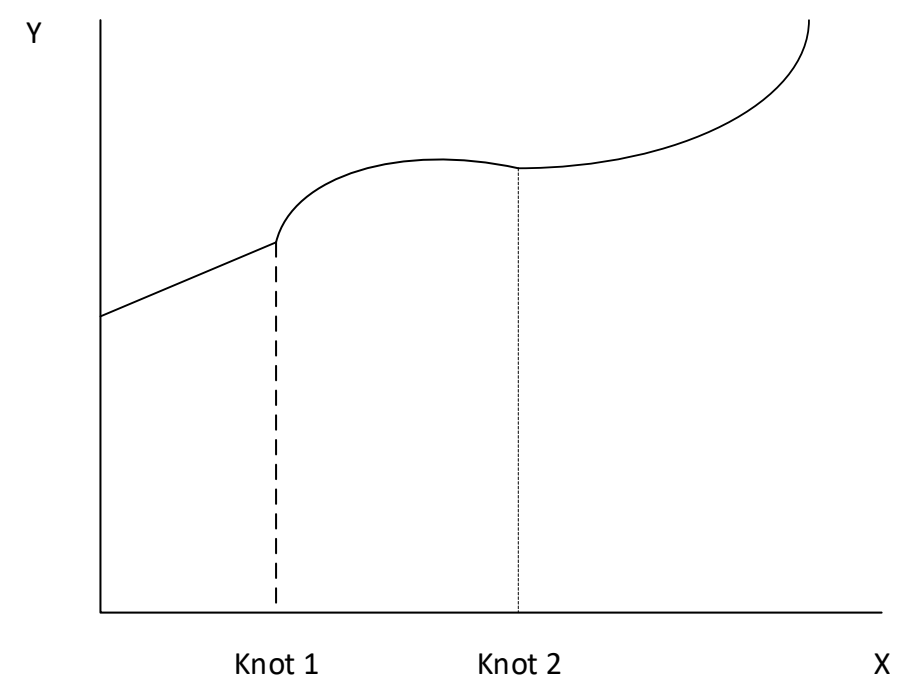

Figure 4: Graph of a MARS model

\section{$\underline{\text { Basis Functions }}$}

A MARS model which does not allow for interactions between independent variables contains only simple/elementary basis functions while a model which allows for variable interactions contains complex basis functions.

A simple basis function consists of a single variable $\mathrm{x}$ and comes in the form of either ( $\mathrm{x}$

$-t)_{+}$or $(t-x)_{+}$where $t$ is the knot, $(x-t)_{+}=(x-t)$ if $x$ is greater than $t$, and is equal to zero 
otherwise; and $(t-x)_{+}=(t-x)$ if $x$ is less than $t$ and is equal to zero otherwise (Osei-Bryson, 2014b). BF1 and BF2 in Table 2 are examples of simple basis functions.

\begin{tabular}{|c|c|}
\hline Simple Basis Functions & Complex Basis Function \\
\hline $\begin{array}{l}\mathrm{BF} 1=\operatorname{MAX}\left(0, V A R \_1-0.1\right) \\
\mathrm{BF} 2=\operatorname{MAX}\left(0,0.1-V A R \_1\right) \\
\mathrm{BF} 1 \text { is equal to }\left(V A R \_1-0.1\right) \text { only if VAR_1 is } \\
\text { greater than } 0.1 \text { and is otherwise equal to } \\
\text { zero. } \\
\text { BF2 is equal to (0.1-VAR_1) only if } 0.1 \text { is } \\
\text { greater than VAR_1 and is otherwise equal to } \\
\text { zero. }\end{array}$ & $\begin{array}{l}\text { BF3 = MAX }\left(0, V A R \_2-0.1\right) \times B F 2 \\
=\operatorname{MAX}\left(0, V A R \_2-0.1\right) * \operatorname{MAX}\left(0,0.2-V A R \_1\right) \\
\text { BF3 is equal to the product of MAX(0,VAR_2-0.1) and } \\
\text { BF2 }\end{array}$ \\
\hline
\end{tabular}

A complex basis function takes the form $h_{k}(x)=\Pi \operatorname{ijfij}\left(x_{i j}\right)$ where $x_{1}, \ldots x_{q}$ are the independent variables and $f_{i j}$ is a BF for the $i_{\text {th }}$ independent variable $x_{i}$ at jth knot. Complex basis functions are the product of at least two simple basis functions. A MARS model that includes complex basis functions demonstrates how independent variables may affect one another. BF3 in Table $\mathbf{2}$ is an example of a complex basis function.

\section{Model Generation and Final Model Selection}

A MARS model is built in two steps, the Forward Stage and the Backward Stage. The Forward Stage begins with a constant to which BFs are added recursively until the model reaches a pre-specified limit. Each BF added in this stage corresponds with the variable-knot combination which most improves model performance given the BFs already within the model. 
The Backward Stage takes the largest model created in the Forward Stage and removes the basis function in it which contributes the least to model performance. The removed basis function is selected based on a residual sum of squares criteria. The new model is then refitted and the process of basis function elimination is repeated again based on the same residual sum of squares criteria until all BFs have been eliminated. This results in a sequence of models which function as candidates for the selection of a final model.

In MARS, final model selection may be based on two different criteria. In cases where a subset of the data is used for training the model, the similarity in the mean squared error (MSE) of models in the test and training data subsets is used as selection criteria. Otherwise, generalized cross-validation (GCV) is used.

\section{$\underline{\text { R-Squared Statistic }}$}

In a regression model, the R-Squared statistic, also known as the coefficient of determination, is a measure of the proportion of variance in the dependent variable that is predicted by the independent variable(s) used in the regression. The statistic is generated based on the value of the variables used to construct the regression model it describes. In simpler terms, the R-Squared is a measure of performance that describes how well a regression model is able to predict values of the dependent variable.

R-Squared scores range from zero to 1 with a higher score indicating better model performance. An R-Squared score can also be interpreted as a percentage. For a model with an R-squared of 0.713 explains $71.3 \%$ of the variance in the dependent variable. 
Each of the MARS models generated in this analysis will have corresponding R-Squared statistics. These R-Squared values will be used to describe the models' performance and to discuss how well the spending categories that are included in the models as independent variables have been able to predict the health outcomes chosen for analysis. The next section describes the dataset examined in this analysis.

\subsection{Description of Data}

I will now proceed to describe the dataset used in this analysis. The data is derived from two sources. The use of funds categories which serve as the independent variables in the health production function are taken from the Canadian Institute for Health Information (ClHI) National Health Expenditure (NHEX) database. All of the population health indicators which serve as dependent variables were taken from the Canadian Socio-economic Information Management (CANSIM) System hosted by Statistics Canada (Stat Can).

Data availability restrictions limited the possibilities for panel analysis to the year 1979 at the earliest for all output variables. For estimates of life expectancy, the latest data is available to the year 2007. The latest data for both deaths from treatable causes and the included infant mortality measures are available up to the year 2011. Input variables were available from the year 1975 to 2013 with additional estimated values for the years 2014 and 2015. 
Based on these restrictions, this analysis will include the three decades of data between 1980 and 2010 in the examination infant mortality and deaths from treatable causes, and will examine the years 1980 to 2007 for the measures of life expectancy.

\subsubsection{Population Health Outcome Indicators}

Below, the definitions of life expectancy, deaths from treatable causes, and infant mortality have been transcribed as they appear in the footnotes of the relevant tables within the CANSIM database. Life expectancy data was taken from CANSIM tables 1020025 and 1020512. Data on gender separated potential years of life lost from treatable causes was taken from CANSIM table 1024312. Data on the number of infant deaths was taken from table 1020030.

\section{Life expectancy}

Statistics Canada describes life expectancy as "the number of years a person would be expected to live, starting at birth (for life expectancy at birth) or at age 65 (for life expectancy at age 65 ) if the age- and sex-specific mortality rates for a given observation period (such as a calendar year) were held constant over the estimated life span." According to StatsCan, "life expectancy is calculated using annual mortality rates by Greville's method for abridged life tables, with five-year age groupings of population and mortality rates." 


\section{Deaths from treatable causes}

In this analysis, the evaluation of preventable deaths will be completed by using the number of potential years of life lost from treatable causes. "Potential years of life lost (PYLL) is the number of years of potential life not lived when a person dies "prematurely", defined for this indicator as before age 75."

Additionally, cause of death in this dataset is defined as the "underlying cause of death." According to StatsCan "This is defined as (a) the disease or injury which initiated the train of events leading directly to death, or (b) the circumstances of the accident or violence which produced the fatal injury. The underlying cause is selected from the conditions listed on the medical certificate of cause of death."

$\underline{\text { Infant mortality }}$

According to StatsCan "Infant mortality corresponds to the death of a child less than one year of age." This research utilizes data on the number of infant deaths. According to StatsCan "death refers to the permanent disappearance of all evidence of life at any time after a live birth has taken place. Stillbirths are excluded."

\subsubsection{Healthcare Use of Funds Categories}

All descriptions for use of funds categories have been transcribed exactly as they appear in the ClHI's NHEX Methodology Notes (CIHI, 2015b). 
Hospitals - Institutions where patients are accommodated on the basis of medical need and are provided with continuing medical care and supporting diagnostic and therapeutic services. Hospitals are licensed or approved as hospitals by a provincial/territorial government, or are operated by the government of Canada, and include those providing acute care, extended and chronic care, rehabilitation and convalescent care, and psychiatric care, as well as nursing stations or outpost hospitals.

Other institutions - Include residential care types of facilities (for the chronically ill or disabled, who reside at the institution more or less permanently) and that are approved, funded or licensed by provincial or territorial departments of health and/or social services. Residential care facilities include homes for the aged (including nursing homes); facilities for persons with physical disabilities, developmental delays, psychiatric disabilities and alcohol and drug problems; and facilities for emotionally disturbed children. Facilities solely of a custodial or domiciliary nature and facilities for transients or delinquents are excluded.

Physicians - Expenditures include primarily professional fees paid by provincial/territorial medical care insurance plans to physicians in private practice. Fees for services rendered in hospitals are included when paid directly to physicians by the plans. Also included are other forms of professional income (salaries, sessional, capitation).

The physicians expenditure category does not include the remuneration of physicians on the payrolls of hospitals or public-sector health agencies; these are included in the appropriate category, for example, hospitals or other health spending. Physician expenditures generally represent amounts that flow through provincial/territorial medical care plans. 
Provinces/territories differ in terms of what the medical care plans cover. CIHI has not attempted to make adjustments to physician expenditures to reflect these differences because only a few provinces, to date, can net out these differences from their data.

Drugs - At the aggregate level, include expenditures on prescribed drugs and non-prescribed products purchased in retail stores. Estimates represent the final costs to consumer including dispensing fees, markups and appropriate taxes.

The drugs category does not include drugs dispensed in hospitals and, generally, in other institutions. These are included with the category of hospitals or other institutions. The classification system is consistent with international standards developed by the Organization for Economic Co-operation and Development (OECD).

Capital - Includes expenditures on construction, machinery, equipment and some software of hospitals, clinics, first-aid stations and residential care facilities. It is based on full-cost or cashbasis accounting principles.

Public health - By governments and government agencies, includes expenditures for items such as food and drug safety, health inspections, health promotion activities, community mental health programs, public health nursing, measures to prevent the spread of communicable disease and occupational health to promote and enhance health and safety at the workplace in public-sector agencies.

Administration - Expenditures related to the cost the cost of providing health insurance programs by the government and private health insurance companies and all costs for the 
infrastructure to operate health departments. The administrative costs of operating hospitals, drug programs, long-term care programs and other non-insured health services are not included under the category of administration, but rather are included under the category of service, for example hospitals, other institutions and drugs

Other health spending - At the aggregate level includes expenditures on home care, medical transportation (ambulances), hearing aids, other appliances and prostheses, health research and miscellaneous healthcare. Some of the subcategories of the aggregate category are defined as follows:

Health research - Expenditures for research activities designed to further knowledge of the determinants of health, health status or methods of providing healthcare, or evaluation of healthcare delivery or of public health programs. The category does not include research carried out by hospitals or drug companies in the course of product development. These amounts would be included with either the hospitals or drugs category.

Other - Expenditures for items such as home care, medical transportation (ambulances) hearing aids, other appliances, training of health workers and voluntary health associations. 


\section{Empirical Analysis}

\subsection{Procedure}

The research questions being asked in this thesis are "How effectively have Canada's provinces spent their healthcare funding?" and "How should spending be prioritized in order to improve health outcomes?" I answer these questions using an empirical analysis of healthcare spending data and health outcomes which:

3. Specifies a model for determining the efficiency of the healthcare spending in Canada's provinces;

4. Defines the categories of healthcare spending which are most significant to determining the production of health outcomes in Canada's provinces.

In this section I outline the procedure used to answer these research questions, describe the dataset being examined, and summarize the output of the analysis. In this analysis effectiveness is measured by analyzing the efficiency with which Canada's provinces have consumed healthcare spending to produce longevity. The specific focus is on scale efficiency analyzed across all 28 years of data, and in a year by year analysis.

In addition to analyzing scale efficiency, I will produce a ranking of categories of health care spending based on their importance in determining each province's efficiency level. This ranking is provided by applying the decision tree induction method to the results of the data envelopment analysis. In other words, the first two steps of the analysis will evaluate how 
efficiently each province has been to produce longevity and will determine the categories of healthcare spending that are most significant in determining this efficiency.

In addition to the analysis of efficiency, an additional analysis of the influence of healthcare spending on deaths from treatable causes and infant mortality will be performed. I will first focuses on the categories of healthcare spending which determine the level of deaths from treatable causes in each province. This is done by applying the multivariate adaptive regression splines technique to model the relationship between healthcare spending and deaths from treatable causes. This same technique is used to model the relationship between infant mortality healthcare spending. Next I give a more detailed description of the entire analysis.

\section{DEA Scale Efficiency Analysis of Longevity}

Figure 5 illustrates the logic model of the procedure used in the analysis of longevity. In the analysis, estimates of life expectancy are used as outputs in a production function where each category of spending is treated as a separate input. The first step is to examine the efficient production of longevity over the entire 28 year dataset using the Efficiency Measurement System (EMS) DEA software.

In this step, each province in each year is treated as a separate decision making unit (DMU) or unit of production. Ten provinces in each of the 28 years of data total 280 DMUs. These DMUs are evaluated by comparison to one another to determine their relative efficiency in producing the included estimates of longevity. These estimates of longevity are female life expectancy at age 65 (FLE65), female 
life expectancy at birth (FLEB), male life expectancy at age 65 (MLE65), and male life expectancy at birth (MLEB).

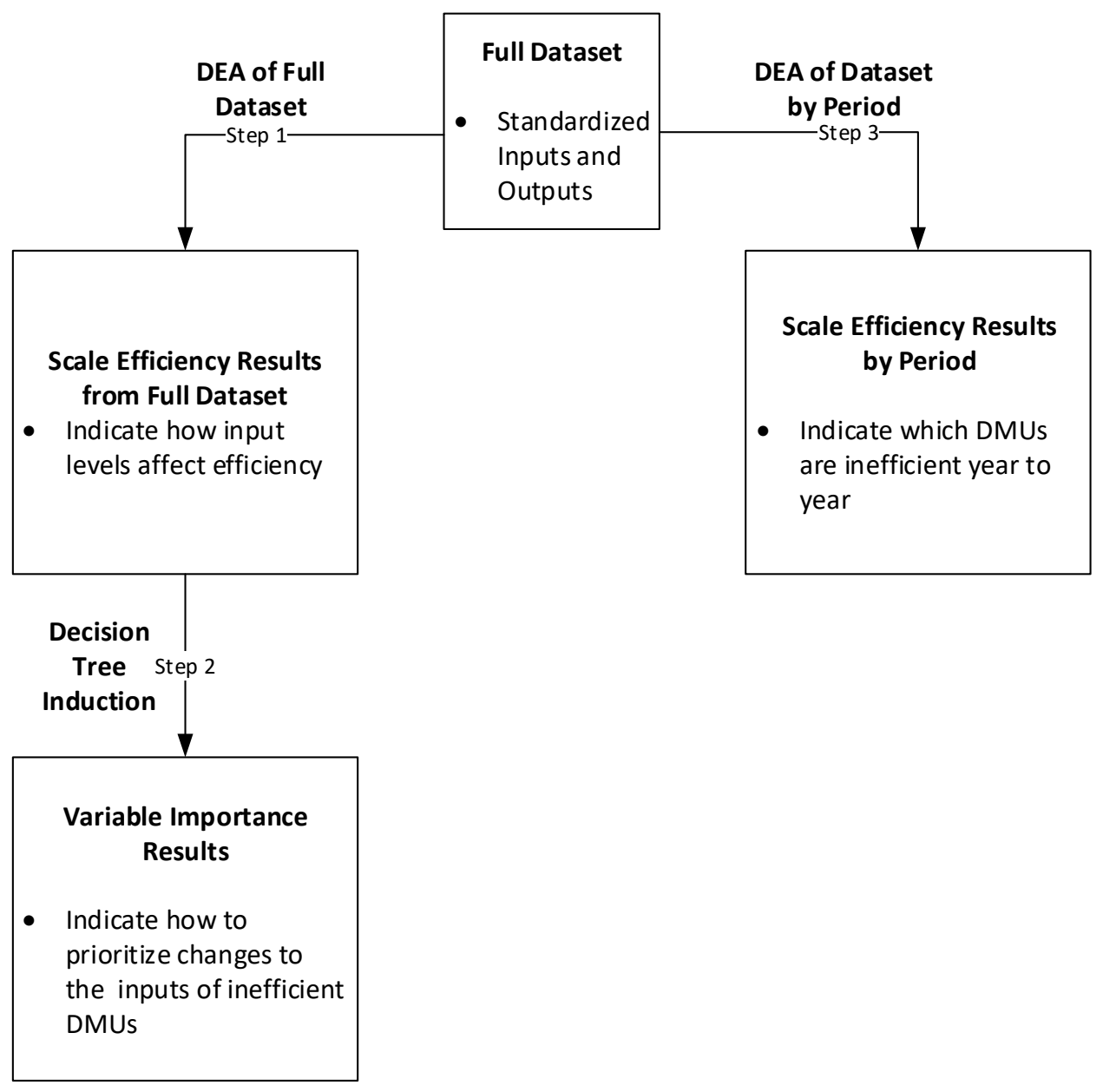

Figure 5: Logic Model of DEA Scale Efficiency Analysis

A total of three input-oriented DEA models are used in this analysis. Input orientation DEA models assume that each DMU is attempting to produce the most output with the least amount of input. These models are constant returns to scale (CRS), variable returns to scale (VRS), and nonincreasing returns to scale (NIRS). Each of the three DEA models assumes different constraints regarding the efficiency of production for each DMU and may produce unique efficiency scores for the same DMU. Efficiency scores range in value from 0 to 100\%. These assumptions correspond with the name of each 
model. The constant returns to scale model assumes that A DMU consumes one unit of input for each unit of output produced. The VRS model assumes that a DMU may produce greater or fewer than one unit of output for each unit of input consumed. The NIRS model indicates the point at which a DMU has maximized its consumption of inputs.

By comparing the efficiency scores from each DEA model we can determine the level of scale efficiency of each DMU. A DMU with a CRS efficiency score of $100 \%$ and a VRS efficiency score of $100 \%$ is operating at its most productive scale size. When a DMU has CRS efficiency score that is less than its VRS score but equal to its NIRS score, that DMU is operating at increasing returns to scale (IRS). When a DMU has a CRS score that is less than its VRS score and less than its NIRS score, that DMU is operating at decreasing returns to scale. The three possible levels of scale efficiency are most productive scale size (MPSS), decreasing returns to scale (DRS) and increasing returns to scale (IRS). A DMU operating at MPSS is operating efficiently. A DMU operating at increasing returns to scale consumes too few inputs to produce an efficient level of output. A DMU operating at DRS consumes inputs above the level of its production of output. This fulfills the goal of determining the performance of the provinces in terms of efficiency.

In the next step, the results of the scale efficiency analysis are inputted into the Salford Predictive Modeller (SPM) software to generate decision trees. These decision trees are generated by including the healthcare spending data as input and the scale efficiency results as output. The decision trees produced in this analysis are classification trees. These classification trees focus on defining the level of healthcare spending that corresponds with a province operating at its most productive scale size and rank the importance of each category of healthcare spending in determining whether or not a province is operating at its most productive scale size. These rankings fulfill the goal of defining $t$ 
In addition to the scale efficiency analysis in which the provinces were compared over 28 years, a second scale efficiency analysis was completed. In this analysis, the provinces' production of longevity was examined year by year. Each province was one of ten DMUs comparatively analyzed in each of the 28 years of data obtained for the measures of longevity. That is, 28 analyses were performed in which each of the 10 provinces were compared to each other using the same procedure described above. This allowed for an evaluation of the scale efficiency of each provinces year over year. As discussed, the next phase examined the influence of spending on infant mortality and deaths from treatable causes. These procedures will be discussed in the next section.

\section{MARS Variable Importance Analysis of Longevity, Infant Mortality \& Deaths from Treatable}

\section{$\underline{\text { Causes }}$}

Identical procedures are used to examine infant mortality \& deaths from treatable causes. Each province in each year was treated as a unique observation in the economic production of infant mortality and deaths from treatable causes. In these production functions the amount of spending in each category was used as one of nine independent variables. The SPM MARS software was used to determine the variable importance rankings for each of these production functions, and to determine the coefficients and knot points of the variables.

Applying MARS allows for interactions between variables which creates complex basis functions within a model. Two-way variable interactions were enabled for the MARS analyses in order to examine how each category of spending interacted with each other. The results of the MARS analysis also report on the performance of each of the models in terms of R-squared scores. An R-squared score corresponds with the accuracy of the model. In this case the R-squared scores provide information on 
the ability of per capita spending to predict infant mortality and PYLL. Moving on, the next section summarizes the descriptive statistics of the data set under analysis.

\subsection{Descriptive Statistics}

In this section I provide a simplified description of trends in Canada's provincial healthcare spending and health outcomes between 1980 and 2010. Given the richness of the dataset that is under analysis, it is beyond the scope of this thesis to fully explore all of the trends in healthcare spending and health outcomes. For our purposes I aim to explain the general trends that appear in the dataset. There are a full set of charts and summary statistics of per capita healthcare spending for each of Canada's provinces is included in Appendix A, and Appendix B contains charts and summary statistics for each of the health outcomes analyzed in this thesis. We proceed by examining common trends in spending across Canada. Afterwards I provide a description of trends in longevity, infant mortality, and deaths due to treatable causes. 


\section{Trends in Per Capita Provincial Healthcare Spending}

This summary describes trends in per capita provincial healthcare spending. A full set of graphs and summary statistics describing healthcare spending data in each of Canada's provinces is available in Appendix A. Per capita spending has increased across all categories of healthcare spending in Canada's all provinces between 1980 and 2010. The size of each province's per-capita spending appears to correspond with the size of the province; larger provinces have higher levels of spending in comparison to smaller provinces.

It appears that the distribution of spending within each category moved in a similar manner from province to province. Capital spending is the only category that varies greatly in each province over the 31 years examined. For example in Newfoundland, spending on capital stayed below $\$ 50$ per person until 1999 where it more than doubled to over $\$ 100$ per person and doubled again in the next year, continuing in a parabolic pattern until 2010. This can be contrasted with spending in Ontario where there is a relatively gradual upward trend in Capital spending 1980 and 2010, or Manitoba where Capital spending has fluctuated and there are several peaks and valleys in capital spending patterns. From year to year, spending on hospitals appears to form the largest segment of total health spending within all provinces while spending on administration forms the smallest. Average spending on hospitals from 1980 and 2010 is more than double the amount of the next closest category in all provinces.

Spending on Administration likely forms the smallest segment of healthcare spending because it this category only includes spending on health insurance programs and health department infrastructure. The administrative costs of operating hospitals, drug programs, long-term care and noninsured services are not included. These summarize the common and noteworthy trends in health spending within the provinces. Next I discuss patterns within the health outcome data beginning with longevity. 
Health Outcomes: Longevity

I will now summarize trends in gender separated measures of longevity. A full set of charts covering and summary statistics covering all of the health outcomes examined in this thesis is available in Appendix B. Data on female life expectancy at age 65 is available in Table 3. Table 4 contains data on female life expectancy at birth. Data on male life expectancy at age 65 is available in Table 5. Table 6 contains the data on male life expectancy at birth.

\begin{tabular}{|c|c|c|c|c|c|c|c|c|c|c|c|}
\hline Year & NL & PEI & NS & NB & Qc & On & Mn & Sk & $\mathbf{A b}$ & BC & Average \\
\hline 1980 & 18.0 & 18.5 & 18.0 & 18.5 & 18.5 & 18.8 & 19.1 & 19.9 & 19.4 & 20.0 & 18.9 \\
\hline 1981 & 18.9 & 20.2 & 18.6 & 19.2 & 19.0 & 19.0 & 19.2 & 20.1 & 19.3 & 19.9 & 19.3 \\
\hline 1982 & 18.4 & 20.9 & 18.8 & 19.3 & 18.8 & 18.9 & 19.2 & 19.6 & 19.4 & 19.7 & 19.3 \\
\hline 1983 & 18.1 & 19.6 & 19.0 & 19.1 & 18.7 & 19.0 & 19.6 & 20.3 & 19.7 & 20.3 & 19.3 \\
\hline 1984 & 18.5 & 19.1 & 18.7 & 19.2 & 19.0 & 19.3 & 19.8 & 20.3 & 20.0 & 20.0 & 19.4 \\
\hline 1985 & 18.5 & 19.6 & 18.8 & 19.8 & 19.1 & 19.1 & 19.7 & 20.1 & 19.8 & 19.9 & 19.4 \\
\hline 1986 & 18.3 & 19.5 & 18.9 & 19.3 & 18.9 & 19.1 & 19.6 & 20.2 & 19.6 & 20.2 & 19.4 \\
\hline 1987 & 19.0 & 19.7 & 19.1 & 19.4 & 19.2 & 19.5 & 20.0 & 20.2 & 20.2 & 20.1 & 19.6 \\
\hline 1988 & 18.5 & 19.9 & 19.2 & 19.7 & 19.3 & 19.4 & 19.8 & 20.6 & 19.8 & 20.0 & 19.6 \\
\hline 1989 & 18.9 & 20.4 & 19.1 & 19.6 & 19.6 & 19.5 & 19.9 & 20.8 & 20.2 & 20.2 & 19.8 \\
\hline 1990 & 18.4 & 19.3 & 19.2 & 19.9 & 19.8 & 19.8 & 20.0 & 20.5 & 20.4 & 20.2 & 19.8 \\
\hline 1991 & 18.5 & 19.8 & 19.7 & 20.2 & 19.9 & 19.7 & 19.9 & 20.7 & 20.3 & 20.4 & 19.9 \\
\hline 1992 & 18.9 & 19.9 & 19.5 & 19.7 & 19.8 & 19.8 & 20.2 & 21.1 & 20.4 & 20.3 & 20.0 \\
\hline 1993 & 19.1 & 20.1 & 19.6 & 19.7 & 19.7 & 19.7 & 20.1 & 21.0 & 20.2 & 20.4 & 20.0 \\
\hline 1994 & 19.1 & 19.8 & 19.6 & 19.9 & 19.8 & 19.8 & 20.0 & 20.8 & 20.3 & 20.4 & 20.0 \\
\hline 1995 & 18.9 & 20.2 & 19.6 & 19.9 & 19.8 & 19.9 & 19.9 & 20.8 & 20.2 & 20.5 & 20.0 \\
\hline 1996 & 18.8 & 19.9 & 19.4 & 19.8 & 19.9 & 19.9 & 19.9 & 20.7 & 20.4 & 20.5 & 19.9 \\
\hline 1997 & 18.7 & 20.4 & 19.6 & 19.9 & 19.9 & 20.0 & 20.0 & 20.7 & 20.4 & 20.6 & 20.0 \\
\hline 1998 & 18.8 & 19.9 & 19.7 & 20.0 & 20.2 & 20.1 & 20.2 & 20.6 & 20.6 & 20.8 & 20.1 \\
\hline 1999 & 19.1 & 20.5 & 19.9 & 20.1 & 20.3 & 20.2 & 20.3 & 20.7 & 20.8 & 21.0 & 20.3 \\
\hline 2000 & 19.2 & 20.1 & 19.8 & 20.2 & 20.5 & 20.4 & 20.4 & 20.8 & 20.9 & 21.1 & 20.3 \\
\hline 2001 & 19.4 & 20.2 & 19.9 & 20.3 & 20.5 & 20.6 & 20.5 & 21.0 & 21.0 & 21.1 & 20.5 \\
\hline 2002 & 19.4 & 20.0 & 20.1 & 20.3 & 20.7 & 20.8 & 20.5 & 21.0 & 21.0 & 21.1 & 20.5 \\
\hline 2003 & 19.4 & 20.3 & 20.2 & 20.5 & 20.9 & 20.9 & 20.6 & 21.1 & 21.2 & 21.3 & 20.6 \\
\hline 2004 & 19.4 & 20.5 & 20.4 & 20.7 & 21.1 & 21.2 & 20.7 & 21.2 & 21.4 & 21.5 & 20.8 \\
\hline 2005 & 19.5 & 20.9 & 20.5 & 20.9 & 21.3 & 21.3 & 20.9 & 21.2 & 21.5 & 21.7 & 21.0 \\
\hline 2006 & 19.4 & 21.0 & 20.7 & 20.9 & 21.5 & 21.6 & 21.1 & 21.2 & 21.6 & 21.8 & 21.1 \\
\hline 2007 & 19.7 & 20.7 & 20.9 & 21.1 & 21.6 & 21.7 & 21.2 & 21.3 & 21.6 & 22.0 & 21.2 \\
\hline Average & 18.9 & 20.0 & 19.5 & 19.9 & 19.9 & 20.0 & 20.1 & 20.7 & 20.4 & 20.6 & \\
\hline
\end{tabular}


Between 1980 and 2007, average female life expectancy at 65 has risen in Canada's provinces by 2.3 years from 18.9 to 21.2 years. Female life expectancy at birth rose by 3.8 years ( 78.9 years to 82.7 years). For male life expectancy at age 65 , there has been an increase of 3.2 years (14.8 years to 18 years) while male life expectancy at birth has risen 6.1 years over the same timeframe (71.8 years to 77.9 years).

\begin{tabular}{|c|c|c|c|c|c|c|c|c|c|c|c|}
\hline Year & NL & PEI & NS & NB & Qc & On & Mn & Sk & $A b$ & BC & Average \\
\hline 1980 & 78.1 & 79.7 & 78.1 & 78.6 & 78.5 & 78.9 & 78.8 & 79.9 & 78.9 & 79.9 & 78.9 \\
\hline 1981 & 79.5 & 80.8 & 78.7 & 79.4 & 79.2 & 79.3 & 78.9 & 80.2 & 79.2 & 79.6 & 79.5 \\
\hline 1982 & 78.9 & 81.2 & 78.9 & 79.5 & 79.2 & 79.4 & 79.1 & 79.6 & 79.7 & 79.9 & 79.5 \\
\hline 1983 & 78.3 & 79.8 & 79.3 & 79.6 & 79.3 & 79.6 & 79.8 & 80.6 & 80.0 & 80.8 & 79.7 \\
\hline 1984 & 78.8 & 80.2 & 79.2 & 80.0 & 79.7 & 79.9 & 80.3 & 80.8 & 80.3 & 80.5 & 80.0 \\
\hline 1985 & 79.1 & 80.6 & 78.9 & 80.1 & 79.6 & 79.8 & 80.0 & 80.2 & 80.1 & 80.5 & 79.9 \\
\hline 1986 & 79.1 & 80.1 & 79.6 & 80.0 & 79.6 & 80.0 & 79.8 & 80.6 & 79.9 & 80.8 & 80.0 \\
\hline 1987 & 79.6 & 80.7 & 79.9 & 80.3 & 79.9 & 80.3 & 80.1 & 80.8 & 80.7 & 81.0 & 80.3 \\
\hline 1988 & 79.2 & 81.2 & 79.6 & 80.7 & 80.1 & 80.3 & 80.4 & 81.1 & 80.5 & 80.8 & 80.4 \\
\hline 1989 & 79.5 & 81.2 & 79.8 & 80.3 & 80.4 & 80.5 & 80.6 & 81.6 & 80.9 & 81.0 & 80.6 \\
\hline 1990 & 79.3 & 80.5 & 79.9 & 80.7 & 80.7 & 80.9 & 80.5 & 81.2 & 81.2 & 81.1 & 80.6 \\
\hline 1991 & 79.7 & 80.8 & 80.7 & 81.0 & 80.9 & 80.8 & 80.6 & 81.4 & 81.2 & 81.5 & 80.9 \\
\hline 1992 & 79.8 & 80.8 & 80.4 & 80.7 & 81.0 & 81.0 & 80.9 & 81.8 & 81.1 & 81.5 & 80.9 \\
\hline 1993 & 80.1 & 80.9 & 80.5 & 80.8 & 80.9 & 81.0 & 80.6 & 81.7 & 81.2 & 81.5 & 80.9 \\
\hline 1994 & 80.2 & 81.1 & 80.6 & 81.0 & 81.0 & 81.1 & 80.6 & 81.5 & 81.3 & 81.6 & 81.0 \\
\hline 1995 & 80.2 & 81.5 & 80.6 & 81.2 & 81.0 & 81.3 & 80.5 & 81.4 & 81.3 & 81.8 & 81.1 \\
\hline 1996 & 80.0 & 81.0 & 80.5 & 81.1 & 81.1 & 81.4 & 80.7 & 81.4 & 81.5 & 81.9 & 81.1 \\
\hline 1997 & 79.9 & 81.2 & 80.8 & 81.3 & 81.3 & 81.6 & 80.7 & 81.6 & 81.7 & 82.2 & 81.2 \\
\hline 1998 & 80.1 & 80.8 & 81.1 & 81.5 & 81.6 & 81.7 & 80.8 & 81.5 & 81.8 & 82.4 & 81.3 \\
\hline 1999 & 80.3 & 81.7 & 81.4 & 81.7 & 81.8 & 81.9 & 81.1 & 81.7 & 82.0 & 82.7 & 81.6 \\
\hline 2000 & 80.6 & 81.7 & 81.4 & 81.9 & 82.0 & 82.1 & 81.2 & 81.8 & 82.1 & 82.8 & 81.8 \\
\hline 2001 & 80.9 & 81.8 & 81.5 & 82.0 & 82.1 & 82.3 & 81.3 & 82.0 & 82.2 & 82.9 & 81.9 \\
\hline 2002 & 81.1 & 81.5 & 81.6 & 82.1 & 82.3 & 82.5 & 81.3 & 82.0 & 82.3 & 82.9 & 82.0 \\
\hline 2003 & 81.0 & 81.8 & 81.7 & 82.2 & 82.5 & 82.6 & 81.4 & 82.0 & 82.6 & 83.1 & 82.1 \\
\hline 2004 & 80.9 & 82.1 & 82.0 & 82.4 & 82.8 & 83.0 & 81.6 & 82.1 & 82.8 & 83.3 & 82.3 \\
\hline 2005 & 80.8 & 82.7 & 82.2 & 82.5 & 83.1 & 83.1 & 81.8 & 82.0 & 82.9 & 83.5 & 82.5 \\
\hline 2006 & 80.9 & 82.9 & 82.3 & 82.7 & 83.3 & 83.4 & 82.0 & 82.1 & 83.0 & 83.6 & 82.6 \\
\hline 2007 & 81.2 & 82.8 & 82.4 & 82.8 & 83.4 & 83.6 & 81.9 & 82.1 & 83.0 & 83.9 & 82.7 \\
\hline Average & 79.9 & 81.2 & 80.5 & 81.0 & 81.0 & 81.2 & 80.6 & 81.3 & 81.3 & 81.8 & \\
\hline
\end{tabular}


For both genders, life expectancy at birth has increased by a larger margin than life expectancy at 65 . To reiterate, the data suggests that in Canada's provinces longevity for newborns has increased by a larger margin than longevity for senior citizens.

\begin{tabular}{|c|c|c|c|c|c|c|c|c|c|c|c|}
\hline Year & NL & PEI & NS & NB & Qc & On & Mn & Sk & $A b$ & BC & Average \\
\hline 1980 & 14.5 & 15.2 & 14.1 & 14.4 & 13.9 & 14.4 & 14.9 & 15.6 & 15.1 & 15.7 & 14.8 \\
\hline 1981 & 14.8 & 14.8 & 14.2 & 14.7 & 14.2 & 14.5 & 14.7 & 16.0 & 15.1 & 15.8 & 14.9 \\
\hline 1982 & 14.9 & 14.8 & 14.3 & 14.7 & 14.2 & 14.6 & 15.1 & 15.2 & 15.0 & 15.4 & 14.8 \\
\hline 1983 & 14.9 & 16.1 & 14.2 & 14.6 & 14.2 & 14.6 & 14.9 & 15.8 & 15.6 & 15.9 & 15.1 \\
\hline 1984 & 14.5 & 15.3 & 14.7 & 14.8 & 14.3 & 14.9 & 15.4 & 16.0 & 15.5 & 15.8 & 15.1 \\
\hline 1985 & 14.5 & 14.5 & 14.3 & 14.7 & 14.2 & 14.8 & 15.2 & 15.7 & 15.5 & 15.9 & 14.9 \\
\hline 1986 & 14.6 & 15.2 & 14.4 & 14.7 & 14.2 & 15.0 & 15.1 & 15.9 & 15.7 & 16.1 & 15.1 \\
\hline 1987 & 14.5 & 14.5 & 14.8 & 15.1 & 14.4 & 15.2 & 15.4 & 16.5 & 15.9 & 16.1 & 15.2 \\
\hline 1988 & 15.2 & 14.7 & 14.6 & 15.0 & 14.5 & 15.0 & 15.2 & 15.9 & 15.7 & 16.2 & 15.2 \\
\hline 1989 & 14.7 & 15.2 & 14.6 & 15.2 & 14.7 & 15.4 & 15.7 & 16.1 & 15.9 & 16.4 & 15.4 \\
\hline 1990 & 14.4 & 15.5 & 15.1 & 15.5 & 15.0 & 15.8 & 15.8 & 16.4 & 16.2 & 16.6 & 15.6 \\
\hline 1991 & 15.0 & 14.3 & 15.3 & 15.5 & 15.1 & 15.8 & 16.0 & 16.4 & 16.2 & 16.6 & 15.6 \\
\hline 1992 & 14.9 & 15.5 & 14.9 & 15.5 & 15.3 & 15.9 & 15.9 & 16.7 & 16.4 & 16.8 & 15.8 \\
\hline 1993 & 14.8 & 15.4 & 15.0 & 15.5 & 15.3 & 15.9 & 15.9 & 16.7 & 16.4 & 16.8 & 15.8 \\
\hline 1994 & 15.0 & 15.2 & 15.2 & 15.5 & 15.4 & 16.0 & 16.1 & 16.7 & 16.5 & 16.9 & 15.9 \\
\hline 1995 & 14.9 & 15.4 & 15.4 & 15.7 & 15.5 & 16.1 & 16.2 & 16.7 & 16.7 & 17.0 & 16.0 \\
\hline 1996 & 14.8 & 15.5 & 15.5 & 15.6 & 15.5 & 16.3 & 16.3 & 16.6 & 16.7 & 17.1 & 16.0 \\
\hline 1997 & 14.9 & 16.0 & 15.7 & 15.7 & 15.6 & 16.4 & 16.2 & 16.5 & 16.8 & 17.2 & 16.1 \\
\hline 1998 & 15.0 & 15.7 & 16.0 & 15.7 & 15.9 & 16.6 & 16.2 & 16.6 & 17.0 & 17.5 & 16.2 \\
\hline 1999 & 15.2 & 16.0 & 16.3 & 16.1 & 16.3 & 16.9 & 16.4 & 16.8 & 17.2 & 17.6 & 16.5 \\
\hline 2000 & 15.4 & 16.0 & 16.4 & 16.3 & 16.5 & 17.2 & 16.7 & 16.9 & 17.4 & 18.0 & 16.7 \\
\hline 2001 & 15.6 & 16.4 & 16.5 & 16.4 & 16.8 & 17.4 & 16.8 & 17.0 & 17.6 & 18.1 & 16.9 \\
\hline 2002 & 15.8 & 16.4 & 16.7 & 16.6 & 17.0 & 17.6 & 16.9 & 17.1 & 17.8 & 18.4 & 17.0 \\
\hline 2003 & 15.8 & 16.9 & 16.8 & 16.8 & 17.3 & 17.8 & 17.0 & 17.4 & 17.9 & 18.5 & 17.2 \\
\hline 2004 & 16.0 & 17.2 & 16.9 & 17.3 & 17.7 & 18.1 & 17.4 & 17.6 & 18.2 & 18.7 & 17.5 \\
\hline 2005 & 16.2 & 17.5 & 17.1 & 17.5 & 18.0 & 18.3 & 17.5 & 17.8 & 18.3 & 18.9 & 17.7 \\
\hline 2006 & 16.5 & 17.6 & 17.4 & 17.7 & 18.2 & 18.5 & 17.6 & 17.8 & 18.4 & 19.0 & 17.9 \\
\hline 2007 & 16.6 & 17.6 & 17.5 & 17.7 & 18.3 & 18.7 & 17.7 & 17.9 & 18.5 & 19.2 & 18.0 \\
\hline Average & 15.1 & 15.7 & 15.5 & 15.7 & 15.6 & 16.2 & 16.1 & 16.6 & 16.6 & 17.1 & \\
\hline
\end{tabular}

An interesting geographical trend also persists across the longevity measures examined. Specifically it appears that Newfoundland trends towards having the shortest life expectancies while 
British Columbia appears to have the longest. Also it appears that moving from the Maritime Provinces towards the Atlantic Provinces, life expectancy trends upward. Ontario stands out as the only province that deviates from this pattern as life expectancy in Ontario is similar to life expectancy in British Columbia. This pattern persists over the 28 years examined. Finally, when comparing genders it appears that females live longer than males across Canada's provinces.

\begin{tabular}{|c|c|c|c|c|c|c|c|c|c|c|c|}
\hline Year & NL & PEI & NS & NB & Qc & On & Mn & Sk & $\mathbf{A b}$ & BC & Average \\
\hline 1980 & 72.0 & 72.4 & 70.7 & 70.8 & 70.8 & 72.0 & 72.2 & 72.5 & 71.7 & 72.5 & 71.8 \\
\hline 1981 & 72.3 & 72.9 & 70.9 & 71.3 & 71.3 & 72.5 & 71.7 & 72.8 & 72.3 & 73.0 & 72.1 \\
\hline 1982 & 72.1 & 73.5 & 71.5 & 71.4 & 71.7 & 72.8 & 72.9 & 72.3 & 72.5 & 73.0 & 72.4 \\
\hline 1983 & 72.2 & 72.4 & 71.3 & 72.3 & 71.8 & 73.1 & 72.5 & 73.5 & 73.6 & 73.8 & 72.7 \\
\hline 1984 & 72.4 & 72.9 & 72.6 & 72.3 & 72.0 & 73.4 & 73.4 & 73.8 & 73.6 & 74.0 & 73.0 \\
\hline 1985 & 72.4 & 72.7 & 72.1 & 72.8 & 72.1 & 73.5 & 72.9 & 73.6 & 73.5 & 74.1 & 73.0 \\
\hline 1986 & 73.5 & 71.9 & 72.4 & 72.5 & 72.2 & 73.7 & 73.2 & 73.5 & 73.6 & 74.5 & 73.1 \\
\hline 1987 & 72.7 & 73.8 & 72.8 & 73.0 & 72.3 & 74.1 & 73.6 & 74.4 & 74.1 & 74.5 & 73.5 \\
\hline 1988 & 73.5 & 73.3 & 72.7 & 73.2 & 72.8 & 74.0 & 73.2 & 73.9 & 74.1 & 74.6 & 73.5 \\
\hline 1989 & 73.3 & 73.0 & 72.9 & 73.7 & 72.9 & 74.4 & 74.0 & 74.7 & 74.6 & 74.7 & 73.8 \\
\hline 1990 & 73.1 & 73.1 & 73.5 & 74.0 & 73.4 & 74.8 & 74.5 & 74.9 & 74.8 & 75.1 & 74.1 \\
\hline 1991 & 73.9 & 72.5 & 73.9 & 74.4 & 73.7 & 75.0 & 74.6 & 75.0 & 75.0 & 75.4 & 74.3 \\
\hline 1992 & 73.9 & 74.3 & 74.0 & 74.4 & 74.1 & 75.2 & 74.7 & 75.5 & 75.4 & 75.5 & 74.7 \\
\hline 1993 & 73.9 & 74.2 & 74.4 & 74.4 & 74.1 & 75.3 & 74.7 & 75.1 & 75.5 & 75.7 & 74.7 \\
\hline 1994 & 74.2 & 74.0 & 74.5 & 74.6 & 74.4 & 75.6 & 75.0 & 75.2 & 75.6 & 75.9 & 74.9 \\
\hline 1995 & 74.4 & 74.6 & 74.8 & 74.8 & 74.6 & 75.9 & 75.2 & 75.3 & 76.0 & 76.2 & 75.2 \\
\hline 1996 & 74.6 & 74.9 & 75.0 & 75.0 & 74.9 & 76.2 & 75.3 & 75.5 & 76.2 & 76.5 & 75.4 \\
\hline 1997 & 74.7 & 75.6 & 75.3 & 75.0 & 75.1 & 76.5 & 75.3 & 75.5 & 76.4 & 76.9 & 75.6 \\
\hline 1998 & 74.8 & 75.2 & 75.6 & 75.2 & 75.5 & 76.8 & 75.2 & 75.6 & 76.7 & 77.4 & 75.8 \\
\hline 1999 & 75.1 & 75.2 & 76.0 & 75.7 & 76.0 & 77.1 & 75.4 & 75.9 & 76.9 & 77.7 & 76.1 \\
\hline 2000 & 75.3 & 75.4 & 76.3 & 76.1 & 76.4 & 77.4 & 75.7 & 76.2 & 77.1 & 78.0 & 76.4 \\
\hline 2001 & 75.6 & 75.9 & 76.4 & 76.3 & 76.7 & 77.6 & 76.0 & 76.2 & 77.3 & 78.2 & 76.6 \\
\hline 2002 & 75.6 & 76.4 & 76.5 & 76.6 & 77.1 & 77.9 & 76.2 & 76.3 & 77.6 & 78.4 & 76.9 \\
\hline 2003 & 75.6 & 76.9 & 76.6 & 76.8 & 77.4 & 78.2 & 76.4 & 76.4 & 77.7 & 78.5 & 77.1 \\
\hline 2004 & 75.6 & 77.3 & 76.8 & 77.3 & 77.9 & 78.5 & 76.7 & 76.7 & 77.9 & 78.7 & 77.3 \\
\hline 2005 & 75.8 & 77.6 & 77.1 & 77.4 & 78.2 & 78.8 & 76.8 & 76.9 & 78.1 & 78.9 & 77.6 \\
\hline 2006 & 76.2 & 77.5 & 77.4 & 77.6 & 78.6 & 79.0 & 76.9 & 76.9 & 78.3 & 79.2 & 77.8 \\
\hline 2007 & 76.5 & 77.5 & 77.7 & 77.5 & 78.8 & 79.2 & 77.0 & 77.0 & 78.5 & 79.5 & 77.9 \\
\hline Average & 74.1 & 74.5 & 74.3 & 74.5 & 74.5 & 75.7 & 74.7 & 75.0 & 75.5 & 76.1 & \\
\hline
\end{tabular}


Health Outcomes: Infant Mortality

The discussion now proceeds to an examination of trends in gender separated measures of infant mortality. Table 7 and Table 8 contain the data on female and male infant deaths respectively. The average number of female infant deaths per year has decreased in Canada's provinces by 81 deaths from 164 to 83 between 1980 and 2010 while the average count of male infant deaths per year has decreased by 114 from approximately 219 to 105 .

\begin{tabular}{|c|c|c|c|c|c|c|c|c|c|c|c|}
\hline Year & NL & PEI & NS & NB & $Q_{c}$ & On & $M n$ & Sk & $A b$ & BC & Average \\
\hline 1980 & 46 & 5 & 53 & 52 & 416 & 501 & 88 & 81 & 211 & 183 & 164 \\
\hline 1981 & 37 & 9 & 53 & 44 & 359 & 446 & 89 & 69 & 192 & 196 & 149 \\
\hline 1982 & 33 & 6 & 43 & 34 & 340 & 434 & 67 & 80 & 192 & 172 & 140 \\
\hline 1983 & 43 & 7 & 50 & 51 & 298 & 446 & 75 & 84 & 186 & 146 & 139 \\
\hline 1984 & 39 & 8 & 42 & 32 & 261 & 440 & 62 & 70 & 199 & 160 & 131 \\
\hline 1985 & 36 & 6 & 43 & 48 & 288 & 415 & 63 & 96 & 150 & 143 & 129 \\
\hline 1986 & 26 & 5 & 41 & 35 & 259 & 426 & 72 & 64 & 168 & 164 & 126 \\
\hline 1987 & 18 & 4 & 27 & 22 & 226 & 404 & 66 & 63 & 136 & 143 & 111 \\
\hline 1988 & 37 & 5 & 33 & 30 & 245 & 383 & 57 & 61 & 146 & 152 & 115 \\
\hline 1989 & 34 & 5 & 31 & 26 & 265 & 441 & 40 & 55 & 132 & 151 & 118 \\
\hline 1990 & 32 & 5 & 38 & 31 & 258 & 421 & 58 & 50 & 149 & 149 & 119 \\
\hline 1991 & 23 & 7 & 27 & 32 & 254 & 428 & 53 & 55 & 131 & 116 & 113 \\
\hline 1992 & 26 & 0 & 31 & 23 & 219 & 377 & 45 & 57 & 142 & 110 & 103 \\
\hline 1993 & 20 & 12 & 41 & 30 & 223 & 394 & 60 & 48 & 118 & 112 & 106 \\
\hline 1994 & 24 & 5 & 31 & 26 & 214 & 384 & 47 & 43 & 126 & 131 & 103 \\
\hline 1995 & 21 & 5 & 24 & 18 & 200 & 388 & 57 & 49 & 120 & 125 & 101 \\
\hline 1996 & 18 & 5 & 29 & 17 & 175 & 341 & 42 & 56 & 99 & 104 & 89 \\
\hline 1997 & 13 & 3 & 21 & 20 & 197 & 316 & 47 & 52 & 75 & 97 & 84 \\
\hline 1998 & 13 & 6 & 25 & 20 & 195 & 305 & 41 & 34 & 77 & 83 & 80 \\
\hline 1999 & 14 & 5 & 14 & 12 & 165 & 321 & 48 & 34 & 101 & 70 & 78 \\
\hline 2000 & 12 & 1 & 21 & 11 & 126 & 336 & 42 & 29 & 101 & 63 & 74 \\
\hline 2001 & 11 & 4 & 22 & 16 & 156 & 309 & 33 & 27 & 81 & 78 & 74 \\
\hline 2002 & 4 & 1 & 11 & 12 & 158 & 308 & 42 & 31 & 136 & 71 & 77 \\
\hline 2003 & 8 & 4 & 15 & 15 & 158 & 324 & 41 & 30 & 106 & 73 & 77 \\
\hline 2004 & 11 & 2 & 16 & 12 & 168 & 338 & 46 & 30 & 105 & 89 & 82 \\
\hline 2005 & 15 & 1 & 17 & 14 & 143 & 352 & 47 & 43 & 122 & 74 & 83 \\
\hline 2006 & 8 & 1 & 18 & 12 & 192 & 284 & 41 & 33 & 107 & 81 & 78 \\
\hline 2007 & 19 & 2 & 14 & 10 & 170 & 317 & 48 & 45 & 142 & 68 & 84 \\
\hline 2008 & 12 & 1 & 19 & 8 & 179 & 325 & 52 & 31 & 151 & 72 & 85 \\
\hline 2009 & 12 & 1 & 15 & 21 & 184 & 322 & 46 & 47 & 134 & 85 & 87 \\
\hline 2010 & 11 & 1 & 20 & 7 & 198 & 308 & 41 & 40 & 133 & 75 & 83 \\
\hline Average & 20 & 4 & 26 & 22 & 206 & 363 & 50 & 48 & 128 & 107 & \\
\hline
\end{tabular}


These measures of infant mortality appear to correlate with each province's population as the smaller provinces have much lower counts and vice versa. As well, it appears that there have been fewer female infant deaths than there have been male deaths within the time frame examined.

\begin{tabular}{|c|c|c|c|c|c|c|c|c|c|c|c|}
\hline Year & NL & PEI & NS & NB & Qc & On & Mn & Sk & $A b$ & BC & Average \\
\hline 1980 & 64 & 17 & 82 & 64 & 537 & 674 & 96 & 112 & 289 & 259 & 219 \\
\hline 1981 & 61 & 16 & 86 & 70 & 448 & 627 & 102 & 134 & 260 & 228 & 203 \\
\hline 1982 & 66 & 9 & 63 & 76 & 460 & 607 & 79 & 106 & 250 & 251 & 197 \\
\hline 1983 & 52 & 9 & 66 & 61 & 378 & 567 & 98 & 96 & 197 & 231 & 176 \\
\hline 1984 & 40 & 8 & 55 & 49 & 384 & 552 & 82 & 99 & 226 & 218 & 171 \\
\hline 1985 & 56 & 2 & 55 & 49 & 338 & 546 & 107 & 104 & 202 & 206 & 167 \\
\hline 1986 & 39 & 8 & 63 & 46 & 345 & 543 & 85 & 93 & 225 & 191 & 164 \\
\hline 1987 & 41 & 9 & 63 & 45 & 368 & 484 & 76 & 92 & 179 & 216 & 157 \\
\hline 1988 & 33 & 9 & 46 & 39 & 318 & 527 & 75 & 79 & 201 & 210 & 154 \\
\hline 1989 & 30 & 7 & 42 & 43 & 367 & 544 & 75 & 79 & 193 & 209 & 159 \\
\hline 1990 & 38 & 7 & 43 & 40 & 354 & 525 & 80 & 73 & 197 & 195 & 155 \\
\hline 1991 & 33 & 6 & 42 & 26 & 324 & 525 & 58 & 71 & 154 & 182 & 142 \\
\hline 1992 & 23 & 3 & 40 & 36 & 303 & 509 & 68 & 53 & 162 & 176 & 137 \\
\hline 1993 & 30 & 4 & 41 & 35 & 306 & 528 & 58 & 67 & 150 & 152 & 137 \\
\hline 1994 & 28 & 6 & 36 & 22 & 292 & 495 & 68 & 82 & 168 & 166 & 136 \\
\hline 1995 & 25 & 3 & 28 & 23 & 277 & 482 & 66 & 74 & 154 & 155 & 129 \\
\hline 1996 & 20 & 3 & 30 & 23 & 221 & 461 & 62 & 56 & 137 & 133 & 115 \\
\hline 1997 & 15 & 4 & 23 & 25 & 247 & 412 & 63 & 62 & 103 & 113 & 107 \\
\hline 1998 & 18 & 6 & 19 & 31 & 230 & 362 & 56 & 57 & 106 & 100 & 99 \\
\hline 1999 & 11 & 5 & 24 & 26 & 196 & 384 & 72 & 45 & 119 & 90 & 97 \\
\hline 2000 & 12 & 4 & 24 & 15 & 214 & 377 & 50 & 53 & 143 & 87 & 98 \\
\hline 2001 & 12 & 6 & 28 & 15 & 193 & 404 & 65 & 41 & 129 & 90 & 98 \\
\hline 2002 & 17 & 1 & 25 & 15 & 188 & 373 & 56 & 36 & 147 & 112 & 97 \\
\hline 2003 & 15 & 3 & 34 & 14 & 164 & 368 & 70 & 46 & 159 & 97 & 97 \\
\hline 2004 & 12 & 4 & 24 & 18 & 174 & 397 & 51 & 44 & 131 & 86 & 94 \\
\hline 2005 & 13 & 2 & 17 & 14 & 210 & 393 & 47 & 56 & 164 & 109 & 103 \\
\hline 2006 & 16 & 2 & 16 & 16 & 223 & 390 & 47 & 42 & 131 & 90 & 97 \\
\hline 2007 & 15 & 5 & 15 & 21 & 209 & 406 & 63 & 32 & 154 & 108 & 103 \\
\hline 2008 & 13 & 2 & 13 & 16 & 200 & 428 & 49 & 54 & 166 & 94 & 104 \\
\hline 2009 & 19 & 4 & 16 & 22 & 205 & 383 & 54 & 49 & 150 & 76 & 98 \\
\hline 2010 & 15 & 4 & 21 & 18 & 242 & 387 & 65 & 44 & 166 & 91 & 105 \\
\hline Average & 25 & 5 & 34 & 29 & 267 & 455 & 67 & 64 & 161 & 142 & \\
\hline
\end{tabular}


Health Outcomes: Deaths from Treatable Causes

In this section I discuss trends in the number of deaths from treatable causes. Table 9

summarizes the data on female deaths from treatable causes while Table 10 contains the data on male deaths from treatable causes.

\begin{tabular}{|c|c|c|c|c|c|c|c|c|c|c|c|}
\hline & NL & PEI & NS & NB & Qc & On & Mn & Sk & $A b$ & BC & Average \\
\hline 1980 & 7,545 & 1,125 & 9,953 & 7,968 & 74,579 & 92,150 & 12,540 & 10,317 & 24,372 & 26,247 & 26,680 \\
\hline 1981 & 5,801 & 1,272 & 9,611 & 7,656 & 68,923 & 88,124 & 12,952 & 9,362 & 22,202 & 29,983 & 25,589 \\
\hline 1982 & 5,661 & 984 & 8,321 & 7,068 & 66,779 & 85,714 & 11,449 & 10,893 & 21,309 & 28,630 & 24,681 \\
\hline 1983 & 6,409 & 1,186 & 8,902 & 7,904 & 65,916 & 87,702 & 11,492 & 10,521 & 23,715 & 24,407 & 24,815 \\
\hline 1984 & 6,231 & 1,011 & 8,691 & 6,017 & 61,173 & 88,480 & 10,620 & 9,730 & 22,685 & 25,650 & 24,029 \\
\hline 1985 & 5,267 & 1,257 & 9,835 & 7,087 & 62,135 & 85,077 & 11,396 & 11,352 & 17,826 & 24,085 & 23,532 \\
\hline 1986 & 5,076 & 875 & 8,719 & 5,940 & 62,130 & 85,875 & 10,543 & 10,095 & 21,604 & 24,790 & 23,565 \\
\hline 1987 & 4,836 & 1,062 & 6,948 & 5,770 & 58,699 & 83,265 & 11,387 & 8,601 & 19,926 & 22,057 & 22,255 \\
\hline 1988 & 5,123 & 889 & 7,683 & 5,624 & 59,865 & 83,936 & 8,855 & 8,805 & 19,398 & 24,625 & 22,480 \\
\hline 1989 & 5,589 & 947 & 7,126 & 5,967 & 60,761 & 86,597 & 7,861 & 8,114 & 19,823 & 24,391 & 22,718 \\
\hline 1990 & 5,254 & 882 & 7,900 & 5,745 & 59,138 & 82,142 & 9,701 & 7,704 & 21,121 & 25,789 & 22,538 \\
\hline 1991 & 4,295 & 1,070 & 7,002 & 5,843 & 57,605 & 80,116 & 8,760 & 8,421 & 18,764 & 21,084 & 1,296 \\
\hline 1992 & 5,000 & 594 & 7,094 & 5,522 & 54,317 & 78,631 & 8,284 & 8,136 & 20,064 & 21,976 & 20,962 \\
\hline 1993 & 4,251 & 1,418 & 7,592 & 5,730 & 55,033 & 80,668 & 9,805 & 8,231 & 18,239 & 20,582 & 21,155 \\
\hline 1994 & 5,278 & 1,006 & 7,560 & 5,288 & 55,191 & 80,576 & 8,327 & 7,394 & 20,049 & 23,395 & 21,406 \\
\hline 1995 & 4,792 & 1,055 & 6,657 & 4,634 & 52,889 & 82,100 & 9,668 & 7,655 & 18,712 & 23,411 & 21,157 \\
\hline 1996 & 4,774 & 983 & 6,704 & 5,033 & 50,727 & 79,363 & 8,386 & 7,859 & 18,372 & 21,469 & 20,367 \\
\hline 1997 & 4,390 & 865 & 7,021 & 4,782 & 51,476 & 71,664 & 9,525 & 7,261 & 17,593 & 22,561 & 19,714 \\
\hline 1998 & 4,053 & 1,248 & 7,436 & 5,617 & 50,342 & 73,301 & 8,495 & 7,065 & 16,290 & 21,983 & 19,583 \\
\hline 1999 & 4,086 & 1,354 & 5,480 & 4,471 & 47,785 & 75,740 & 8,744 & 6,997 & 17,713 & 20,487 & 19,286 \\
\hline 2000 & 4,080 & 672 & 6,458 & 3,887 & 42,559 & 74,146 & 8,150 & 6,290 & 17,481 & 20,461 & 18,418 \\
\hline 2001 & 3,923 & 992 & 5,900 & 4,246 & 45,628 & 73,103 & 7,230 & 6,301 & 18,581 & 21,608 & 18,751 \\
\hline 2002 & 3,844 & 665 & 5,301 & 4,030 & 44,283 & 71,708 & 8,529 & 6,010 & 21,189 & 19,746 & 18,531 \\
\hline 2003 & 3,281 & 1,035 & 6,326 & 4,296 & 43,674 & 75,922 & 8,784 & 7,002 & 19,719 & 19,826 & 18,987 \\
\hline 2004 & 3,682 & 807 & 5,331 & 3,493 & 44,167 & 77,440 & 8,632 & 5,973 & 18,879 & 21,382 & 18,979 \\
\hline 2005 & 4,276 & 514 & 5,241 & 3,946 & 43,512 & 77,017 & 8,953 & 6,312 & 19,728 & 20,469 & 18,997 \\
\hline 2006 & 4,311 & 782 & 5,489 & 3,789 & 44,028 & 72,391 & 7,959 & 6,269 & 19,843 & 20,839 & 18,570 \\
\hline 2007 & 4,245 & 763 & 5,678 & 3,270 & 44,953 & 76,186 & 9,088 & 7,364 & 21,492 & 21,579 & 19,462 \\
\hline 2008 & 3,858 & 636 & 5,768 & 3,511 & 46,650 & 76,222 & 10,094 & 6,937 & 23,954 & 21,984 & 19,961 \\
\hline 2009 & 3,204 & 964 & 5,800 & 4,424 & 47,094 & 73,891 & 8,545 & 7,622 & 22,196 & 21,957 & 19,570 \\
\hline 2010 & 3,814 & 622 & 5,754 & 3,681 & 46,866 & 74,333 & 8,060 & 7,594 & 20,669 & 21,438 & 19,283 \\
\hline Average & 4,544 & 934 & 6,836 & 4,984 & 52,093 & 78,843 & 9,138 & 7,772 & 19,844 & 22,287 & \\
\hline
\end{tabular}


The average yearly count of PYLL due to deaths from treatable causes has fallen by 7,397 years $(26,680$ to 19,283$)$ for females over the 31 years examined while for males the average yearly count has fallen by 12,336 years $(34,182$ to 21,846$)$. As with the infant mortality measures, this variable appears to correlate heavily with a province's population as the smaller provinces have much lower values than their larger counterparts. Additionally, it appears that male deaths occur more often than female deaths within the timeframe examined. We now move on to the results of the empirical analysis beginning with the efficiency evaluation of longevity.

\begin{tabular}{|c|c|c|c|c|c|c|c|c|c|c|c|}
\hline Year & NL & PEI & NS & NB & QC & On & Mn & Sk & $\mathbf{A b}$ & BC & Average \\
\hline 1980 & 8,447 & 1,854 & 13,039 & 9,903 & 93,932 & 118,532 & 14,827 & 13,450 & 32,474 & 35,366 & 34,182 \\
\hline 1981 & 8,519 & 2,011 & 13,501 & 10,287 & 89,817 & 113,029 & 15,047 & 15,287 & 29,308 & 35,220 & 33,203 \\
\hline 1982 & 8,579 & 1,668 & 10,878 & 11,416 & 87,735 & 113,410 & 13,609 & 14,147 & 27,507 & 36,203 & 32,515 \\
\hline 1983 & 7,987 & 1,602 & 12,430 & 9,154 & 82,729 & 106,794 & 15,189 & 12,634 & 25,495 & 32,197 & 30,621 \\
\hline 1984 & 7,414 & 1,279 & 10,085 & 7,629 & 79,846 & 105,859 & 12,821 & 13,107 & 25,777 & 31,415 & 29,523 \\
\hline 1985 & 8,427 & 1,368 & 10,342 & 7,964 & 73,427 & 105,778 & 14,648 & 13,709 & 21,235 & 29,387 & 28,629 \\
\hline 1986 & 5,865 & 1,994 & 10,652 & 8,205 & 76,956 & 104,232 & 12,949 & 12,908 & 24,984 & 27,724 & 28,647 \\
\hline 1987 & 6,229 & 1,383 & 9,517 & 8,294 & 75,581 & 93,854 & 11,524 & 11,115 & 22,377 & 30,148 & 27,002 \\
\hline 1988 & 6,435 & 1,373 & 9,600 & 7,105 & 70,302 & 97,489 & 10,798 & 11,534 & 24,351 & 29,193 & 26,818 \\
\hline 1989 & 6,141 & 1,463 & 9,263 & 6,966 & 74,914 & 99,742 & 11,282 & 10,895 & 22,334 & 28,237 & 27,124 \\
\hline 1990 & 6,420 & 1,280 & 8,186 & 6,426 & 70,426 & 92,480 & 10,680 & 9,989 & 24,684 & 29,109 & 25,968 \\
\hline 1991 & 5,447 & 1,217 & 8,474 & 5,782 & 66,270 & 89,971 & 11,152 & 9,936 & 20,862 & 26,136 & 24,525 \\
\hline 1992 & 4,942 & 845 & 8,069 & 6,339 & 64,312 & 91,834 & 10,071 & 7,294 & 22,032 & 27,576 & 24,331 \\
\hline 1993 & 6,080 & 934 & 7,698 & 6,513 & 64,309 & 95,590 & 9,845 & 8,706 & 21,332 & 25,240 & 24,625 \\
\hline 1994 & 5,729 & 1,261 & 7,794 & 5,290 & 61,094 & 93,102 & 10,589 & 10,088 & 21,827 & 25,741 & 24,252 \\
\hline 1995 & 5,158 & 943 & 7,006 & 5,856 & 62,346 & 89,505 & 10,431 & 10,725 & 21,820 & 24,980 & 23,877 \\
\hline 1996 & 4,826 & 1,196 & 7,320 & 5,257 & 56,724 & 89,369 & 10,053 & 9,615 & 19,853 & 24,589 & 22,880 \\
\hline 1997 & 4,594 & 706 & 6,683 & 5,543 & 57,958 & 81,729 & 9,614 & 9,107 & 18,409 & 22,638 & 21,698 \\
\hline 1998 & 4,014 & 1,026 & 7,049 & 5,647 & 55,439 & 78,270 & 9,972 & 7,844 & 18,508 & 22,910 & 21,068 \\
\hline 1999 & 4,468 & 1,065 & 6,253 & 6,118 & 51,549 & 81,480 & 11,069 & 7,984 & 19,514 & 23,641 & 21,314 \\
\hline 2000 & 4,580 & 1,168 & 7,044 & 4,707 & 51,562 & 82,214 & 9,024 & 8,367 & 21,644 & 21,888 & 21,220 \\
\hline 2001 & 3,978 & 1,394 & 6,687 & 4,885 & 48,748 & 79,903 & 10,760 & 7,812 & 21,268 & 22,497 & 20,793 \\
\hline 2002 & 4,161 & 831 & 6,271 & 4,206 & 46,977 & 81,118 & 9,437 & 7,557 & 22,090 & 23,031 & 20,568 \\
\hline 2003 & 4,144 & 784 & 7,241 & 4,510 & 47,368 & 81,503 & 10,897 & 8,008 & 22,931 & 22,798 & 21,018 \\
\hline 2004 & 4,362 & 810 & 6,991 & 4,892 & 46,549 & 83,592 & 9,472 & 7,395 & 21,996 & 22,924 & 20,898 \\
\hline 2005 & 4,940 & 967 & 6,873 & 4,912 & 49,514 & 82,047 & 9,484 & 8,996 & 24,833 & 23,783 & 21,635 \\
\hline 2006 & 4,711 & 954 & 6,676 & 4,643 & 51,187 & 81,615 & 9,500 & 8,402 & 22,388 & 22,566 & 21,264 \\
\hline 2007 & 4,256 & 1,356 & 6,376 & 5,128 & 48,452 & 84,892 & 10,663 & 7,359 & 25,002 & 25,157 & 21,864 \\
\hline 2008 & 4,336 & 969 & 6,085 & 4,612 & 47,480 & 86,398 & 10,855 & 8,404 & 25,505 & 23,909 & 21,855 \\
\hline 2009 & 5,073 & 953 & 6,298 & 5,396 & 48,122 & 84,048 & 10,556 & 7,499 & 24,981 & 21,808 & 21,473 \\
\hline 2010 & 4,530 & 715 & 7,100 & 5,145 & 47,759 & 84,357 & 10,104 & 8,349 & 26,189 & 24,210 & 21,846 \\
\hline Average & 5,330 & 1,137 & 7,859 & 5,969 & 59,925 & 89,599 & 10,837 & 9,476 & 22,651 & 25,551 & \\
\hline \multicolumn{12}{|c|}{$\begin{array}{l}\text { Table } 10 \text {-Number of Potential Years ot } \\
\text { Province, Annually - } 1980 \text { to } 2010\end{array}$} \\
\hline
\end{tabular}




\subsubsection{Results: Analysis of Longevity}

\section{Evaluation of Healthcare Spending Efficiency}

Here I discuss the results of the analysis of the efficient production of longevity across 28 years of data and. The results indicating the provinces which were operating at most productive scale size are summarized by measure of longevity in Table 11. The results indicate that provinces were only operating at their most productive scale size in either 1980 or 1981, the two earliest years examined. Within the rest of the time frame, the provinces were operating at decreasing returns to scale.

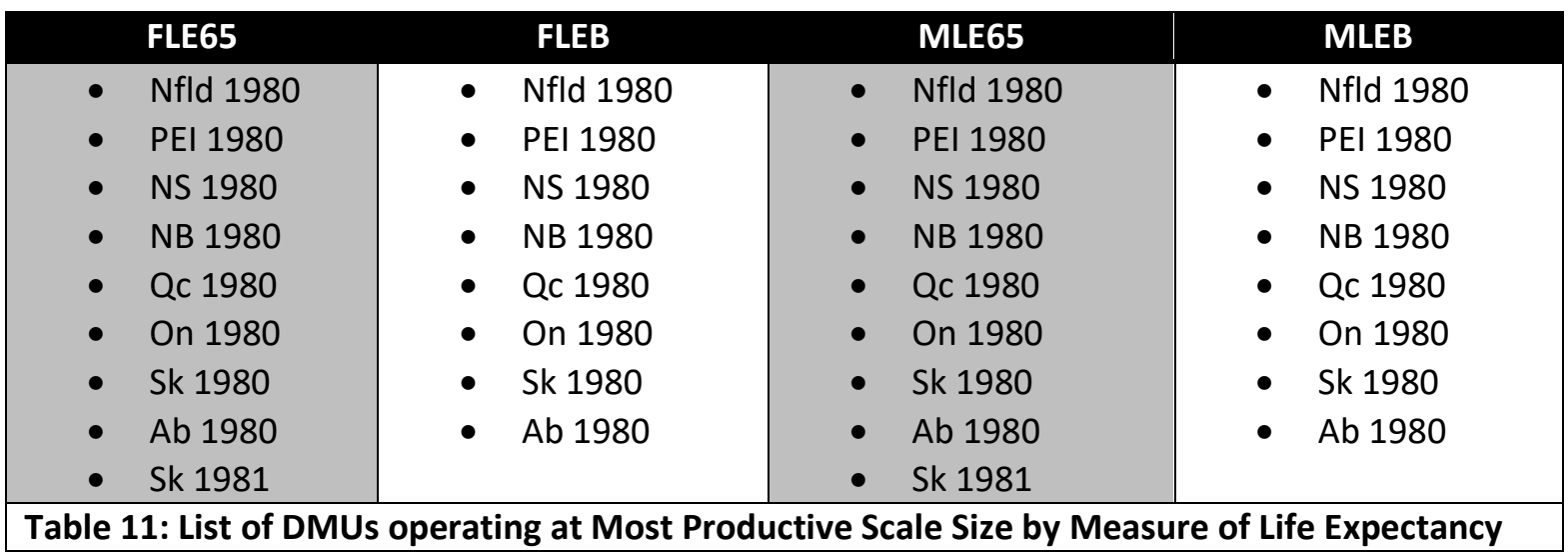

Evaluation of Variable Importance

The results of the analysis of variable importance are summarized below. Table 12 summarizes the results of the variable importance of the categories of the categories of healthcare spending in determining the efficient production of both male and female life expectancy at birth. Table 13 summarizes the results of the importance of the healthcare spending categories for determining male and female life expectancy at age 65 . 


\begin{tabular}{|c|c|c|}
\hline \multicolumn{3}{|c|}{ FLEB } \\
\hline Category \& Rank & Relative Importance Score & First Difference \\
\hline 1. Hospitals & 100 & 0 \\
\hline 2. Other Health Spending & 98.0239 & 0.7729 \\
\hline 3. Other Institutions & 97.2510 & 1.4348 \\
\hline 4. Physicians & 95.8162 & 1.389 \\
\hline 5. Administration & 94.4447 & 1.3715 \\
\hline 6. Other Professionals & 94.4414 & 4.0033 \\
\hline 7. $\quad$ Public Health & 1.5041 & 88.9373 \\
\hline Capital & 0 & 1.5041 \\
\hline Drugs & 0 & 0 \\
\hline \multicolumn{3}{|c|}{ MLEB } \\
\hline 1. Hospitals & 100 & 0 \\
\hline 2. Other Institutions & 94.9756 & 5.0244 \\
\hline 3. Other Health Spending & 94.2778 & 0.6978 \\
\hline 4. Physicians & 93.5849 & 0.6929 \\
\hline 5. Administration & 92.2134 & 1.3715 \\
\hline 6. Other Professionals & 88.2101 & 4.0033 \\
\hline 7. Public Health & 0 & 88.2101 \\
\hline Capital & 0 & 0 \\
\hline Drugs & 0 & 0 \\
\hline
\end{tabular}

The results indicate that spending on hospitals was the most important determinant of whether or not provinces were operating at their most productive scale size in producing all four measures of longevity. The results also indicate that spending on Drugs was the least important category for determining whether or not a province was operating at its most productive scale size in producing all four measures of longevity. Overall, while the Relative Importance Scores of spending categories differ for each measure of longevity, there appear to be common trends in both genders when examining life expectancy at age 65 versus life expectancy at birth. Therefore there are differences in the importance of spending categories based on whether one is examining life expectancy at age 65 or at birth.

In both Table 15 and Table 16, the first differences columns indicate the separation in importance from one category of spending to the next. The results concerning the efficient production of life expectancy at birth indicate that there is not a drastic separation in the importance of any of the spending categories that are considered important. Additionally, only six categories of the nine 
healthcare spending are considered to be important to determining the efficient production of life expectancy at birth. In contrast, the results of the analysis concerning the efficient production of life expectancy at age 65 indicate that seven categories of the nine categories of life expectancy are significant. a dramatic difference between the sixth and seventh ranked categories of healthcare spending.

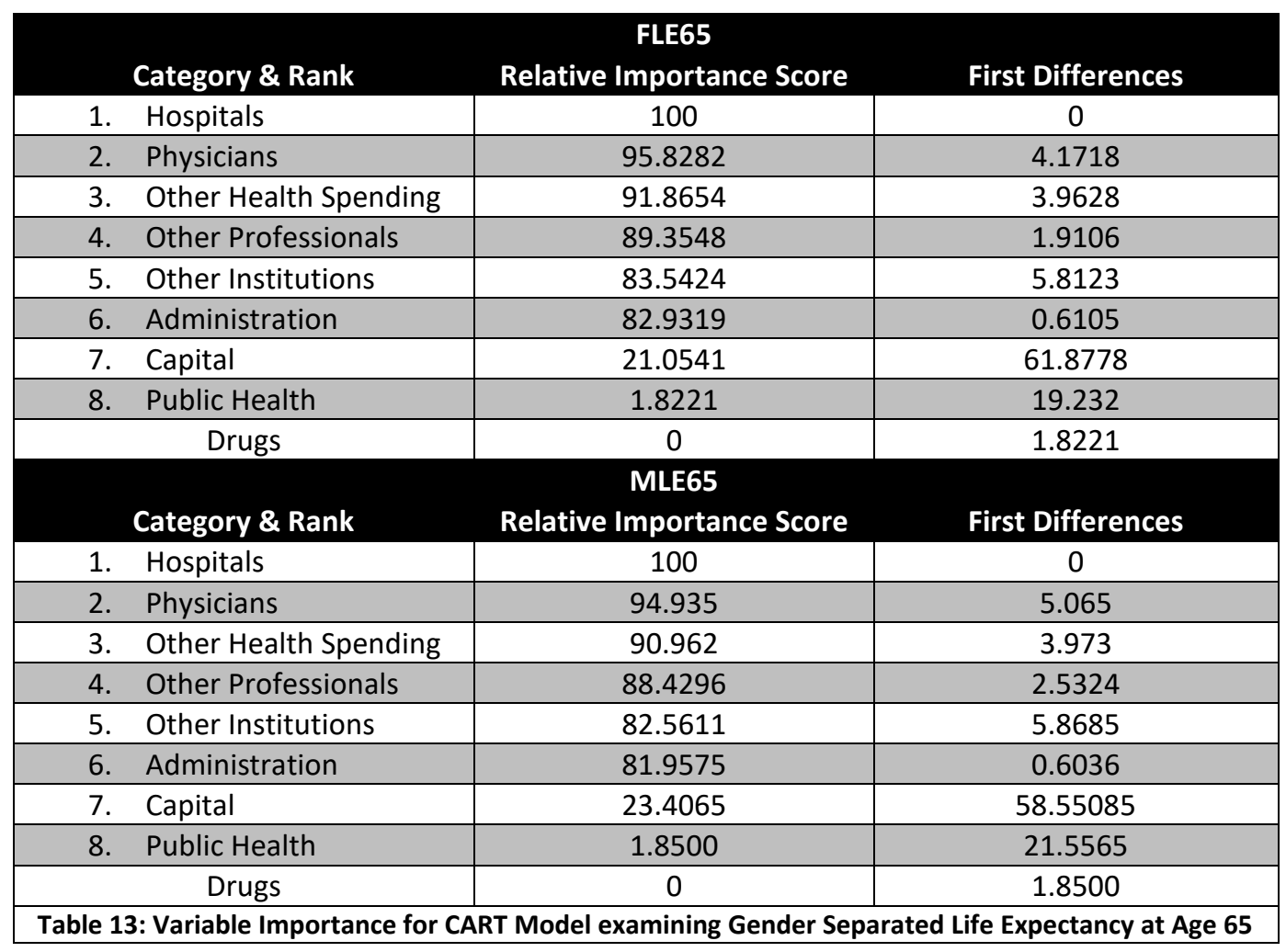

\section{Scale Efficiency Window Analysis: Results}

The results of the year by year analysis of the efficient production of longevity in Canada's provinces are summarized below. Table 14 summarizes the counts of each inefficient province's instances of inefficiency by measure of life expectancy. These provinces include Manitoba, Ontario, British Columbia and New Brunswick. Prince Edward Island also has one instance in which it performs at increasing returns to scale. 


\begin{tabular}{|l|c|c|c|c|c|}
\hline \multicolumn{1}{r}{ FLE65 } & FLEB & MLE65 & MLEB & Total \\
\hline Manitoba & 16 & 16 & 19 & 16 & 67 \\
\hline Ontario & 8 & 7 & 7 & 7 & 29 \\
\hline New Brunswick & 2 & 4 & 2 & 5 & 13 \\
\hline British Columbia & 3 & 3 & 2 & 3 & 11 \\
\hline Prince Edward Island & 0 & 0 & 1 & 0 & 1 \\
\hline Total & 29 & 30 & 31 & 31 & 121 \\
\hline Table 14: Instances of Scale Inefficiency by Province and Category of Life Expectancy Estimate \\
\hline
\end{tabular}

Tables 15 contains the results of the analysis of the efficient production of male life expectancy at birth and at age 65 . Table 16 contains the results of the analysis of the efficient production of female life expectancy at birth and age 65. Both tables indicate the years in which each province was inefficient and whether the province performed at increasing returns to scale or decreasing returns to scale.

\begin{tabular}{|c|c|c|c|c|}
\hline \multirow[b]{2}{*}{ Year } & \multicolumn{2}{|c|}{ Female Life Expectancy at Birth } & \multicolumn{2}{|c|}{ Female Life Expectancy at 65} \\
\hline & Provinces at DRS & Provinces at IRS & Provinces at DRS & Provinces at IRS \\
\hline 1980 & $\begin{array}{c}\text { British Columbia, } \\
\text { Manitoba }\end{array}$ & & $\begin{array}{c}\text { British Columbia, } \\
\text { Manitoba }\end{array}$ & \\
\hline 1981 & British Columbia & Manitoba & $\begin{array}{c}\text { British Columbia, } \\
\text { Manitoba }\end{array}$ & \\
\hline 1982 & $\begin{array}{c}\text { British Columbia, } \\
\text { Manitoba }\end{array}$ & & $\begin{array}{c}\text { British Columbia, } \\
\text { Manitoba }\end{array}$ & \\
\hline 1983 & Manitoba & & Manitoba & \\
\hline 1984 & Manitoba & & Manitoba & \\
\hline 1985 & Manitoba & & Manitoba & \\
\hline 1986 & Manitoba & & Manitoba & \\
\hline 1987 & Manitoba & & Manitoba & \\
\hline 1988 & Ontario & & & Ontario \\
\hline 1989 & Ontario & & & Ontario \\
\hline 1991 & $\begin{array}{c}\text { New Brunswick, } \\
\text { Ontario }\end{array}$ & & & \\
\hline 1992 & New Brunswick & & & Ontario \\
\hline 1993 & $\begin{array}{c}\text { New Brunswick, } \\
\text { Ontario }\end{array}$ & & New Brunswick & Ontario \\
\hline 1994 & $\begin{array}{c}\text { New Brunswick, } \\
\text { Ontario }\end{array}$ & & $\begin{array}{c}\text { New Brunswick, } \\
\text { Ontario }\end{array}$ & \\
\hline 1995 & Ontario & & Ontario & \\
\hline 1996 & Ontario & Manitoba & Manitoba, Ontario & \\
\hline 1997 & Manitoba & & Manitoba & \\
\hline 1998 & & Manitoba & & Ontario \\
\hline 2000 & & Manitoba & & Manitoba \\
\hline 2003 & & Manitoba & & Manitoba \\
\hline 2004 & & Manitoba & & Manitoba \\
\hline 2005 & & Manitoba & & Manitoba \\
\hline 2006 & & Manitoba & Manitoba & \\
\hline
\end{tabular}




\begin{tabular}{|c|c|c|c|c|}
\hline \multirow[b]{2}{*}{ Year } & \multicolumn{2}{|c|}{ Male Life Expectancy at Birth } & \multicolumn{2}{|c|}{ Male Life Expectancy at 65} \\
\hline & Provinces at DRS & Provinces at IRS & Provinces at DRS & Provinces at IRS \\
\hline 1980 & $\begin{array}{c}\text { British Columbia, } \\
\text { Manitoba }\end{array}$ & & $\begin{array}{c}\text { British Columbia } \\
\text { Manitoba }\end{array}$ & \\
\hline 1981 & $\begin{array}{c}\text { British Columbia, } \\
\text { Manitoba }\end{array}$ & & $\begin{array}{c}\text { British Columbia, } \\
\text { Manitoba }\end{array}$ & \\
\hline 1982 & $\begin{array}{c}\text { British Columbia, } \\
\text { Manitoba }\end{array}$ & & Manitoba & \\
\hline 1983 & Manitoba & & Manitoba & \\
\hline 1984 & Manitoba & & Manitoba & \\
\hline 1985 & Manitoba & & Manitoba & \\
\hline 1986 & Manitoba & & & Manitoba \\
\hline 1987 & Manitoba & & Manitoba & \\
\hline 1988 & Ontario & & & Ontario \\
\hline 1989 & & & Ontario & \\
\hline 1991 & $\begin{array}{c}\text { New Brunswick, } \\
\text { Ontario }\end{array}$ & & & $\begin{array}{l}\text { Ontario, Prince } \\
\text { Edward Island }\end{array}$ \\
\hline 1992 & New Brunswick & & & \\
\hline 1993 & $\begin{array}{c}\text { New Brunswick, } \\
\text { Ontario }\end{array}$ & & $\begin{array}{c}\text { New Brunswick, } \\
\text { Ontario }\end{array}$ & \\
\hline 1994 & $\begin{array}{c}\text { New Brunswick, } \\
\text { Ontario }\end{array}$ & & $\begin{array}{c}\text { New Brunswick, } \\
\text { Ontario }\end{array}$ & \\
\hline 1995 & $\begin{array}{c}\text { New Brunswick, } \\
\text { Ontario }\end{array}$ & & Ontario & \\
\hline 1996 & Ontario & Manitoba & Manitoba, Ontario & \\
\hline 1997 & & Manitoba & Manitoba & \\
\hline 1998 & & Manitoba & & Manitoba \\
\hline 1999 & & & & Manitoba \\
\hline 2000 & & Manitoba & & Manitoba \\
\hline 2002 & & & & Manitoba \\
\hline 2003 & & Manitoba & & Manitoba \\
\hline 2004 & & Manitoba & & Manitoba \\
\hline 2005 & & Manitoba & & Manitoba \\
\hline 2006 & & Manitoba & & Manitoba \\
\hline 2007 & & & & Manitoba \\
\hline
\end{tabular}

The results demonstrate that across all measures of life expectancy, Manitoba was inefficient the most frequently (67 total instances of inefficiency). In total Manitoba performed at decreasing returns to scale 36 times across all four window analyses and at increasing returns to scale 31 times. Ontario was scale inefficient a total of 29 times in all four window analyses (21 instances at decreasing returns to scale, eight at increasing returns to scale). British Columbia was inefficient 11 times (eight times at decreasing returns to scale and three at increasing returns to scale). New Brunswick was 
inefficient 13 times (12 times at decreasing returns to scale and once at increasing returns to scale). Prince Edward Island's performed at increasing returns to scale the single time it appeared inefficient. The results indicate that for both categories of female life expectancy there were less instances of inefficiency than for the male categories (29 instances for female life expectancy at age 65 and 30 instance for female life expectancy at birth, 31 for both male life expectancy at birth and 31 instance for male life expectancy at age 65).

\subsubsection{Results: Analysis of Infant Mortality and Deaths from Treatable Causes}

This section summarizes the results of the analyses of infant mortality and deaths due to treatable causes. The MARS settings used for this analysis included all nine categories of spending as independent variables. Additionally, two-way interactions between each dependent variable were allowed, creating models that demonstrated the relationships between each spending category. Below I provide the summary of the ranking independent variable importance (i.e. the ranking of the importance of healthcare spending categories in determining infant mortality and deaths from treatable causes), interactions between independent variables, and the performance of each model that was generated. Next I begin by stating the results of the analysis of deaths from treatable causes.

\section{Results: Deaths from Treatable Causes}

Table 17 contains data on the variable importance scores examining potential years of life lost due to deaths from treatable causes. The MARS variable importance results for both genders indicate that spending on Physicians, Hospitals, Drugs and Public Health have an effect in determining the loss of life due to treatable causes. The five other spending categories included in the models all have a relative 
importance score of zero. For FPYLL the order of spending categories from most to least important is Physicians, Hospitals, Drugs, and Public Health. There is a difference in ranking between FPYLL and MPYLL. Specifically for MPYLL, spending on Drugs is second in importance while spending on Hospitals is third. Spending on Physicians and spending on Public Health remain first and fourth in importance respectively.

Additionally there is a clear difference in the variable importance scores reported by the two models. An examination of first differences in variable importance scores indicates that for FPYLL, after spending on Hospitals is considered, the remaining three variables are quite similar in their importance. This contrasts the first differences of variable importance scores for MPYLL where it is clear that spending on Drugs and Physicians are closer in importance to each other than spending Hospitals and Public Health are to each other.

\begin{tabular}{|c|c|c|}
\hline Variable by Rank & $\begin{array}{c}\text { FPYLL } \\
\text { Relative Importance Scores }\end{array}$ & First Differences \\
\hline 1. Physicians & 100 & 0 \\
\hline 2. Hospitals & 89.69 & 10.31 \\
\hline 3. Drugs & 89.03 & 0.66 \\
\hline 4. Public Health & 87.85 & 1.18 \\
\hline Capital & 0 & 87.85 \\
\hline Other Institutions & 0 & 0 \\
\hline Administration & 0 & 0 \\
\hline Other Professionals & 0 & 0 \\
\hline Other Health Spending & 0 & 0 \\
\hline Variable by Rank & $\begin{array}{c}\text { MPYLL } \\
\text { Relative Importance Scores }\end{array}$ & First Differences \\
\hline 1. Physicians & 100 & 0 \\
\hline 2. Drugs & 93.17 & 6.83 \\
\hline 3. Hospitals & 79.07 & 14.1 \\
\hline 4. Public Health & 77.75 & 1.32 \\
\hline Capital & 0 & 77.75 \\
\hline Other Institutions & 0 & 0 \\
\hline Administration & 0 & 0 \\
\hline Other Professionals & 0 & 0 \\
\hline Other Health Spending & 0 & 0 \\
\hline
\end{tabular}


The results on variable interactions are reported in Table 18. Both MARS models indicate that there are no interactions between spending on Hospitals and spending on Physicians. In both models, all other categories of spending have at least one interaction with each other.

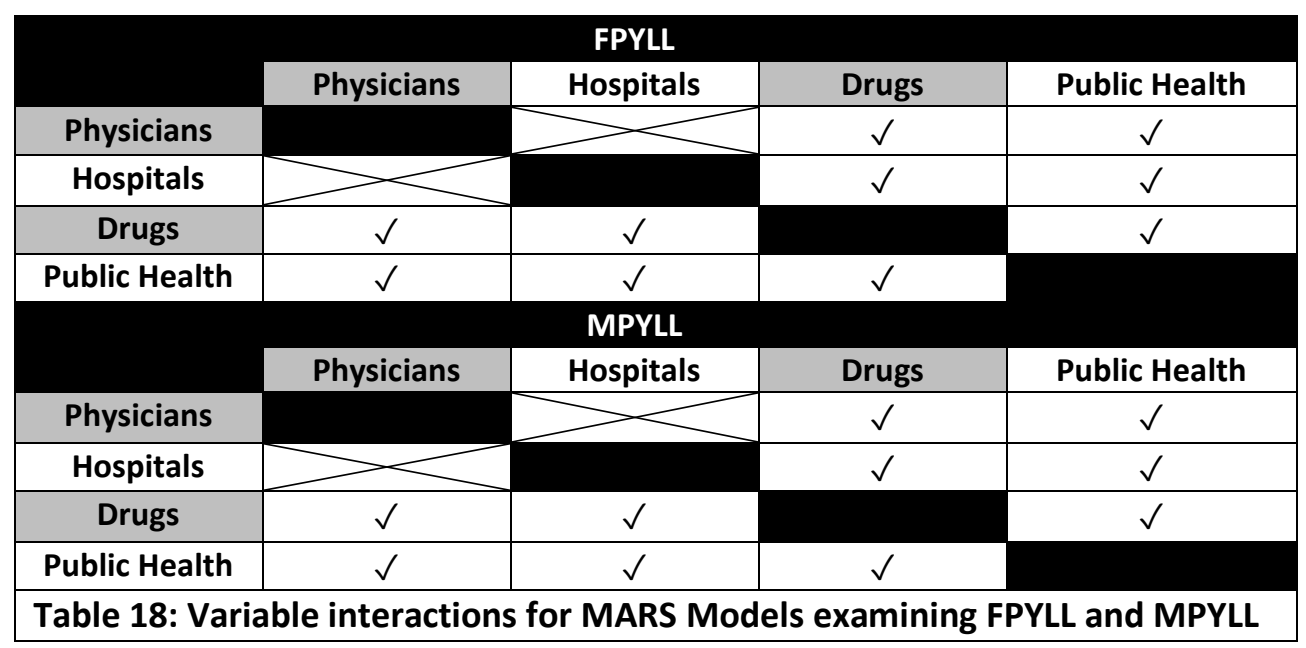

Finally, the measures of performance for both models are summarized in Table 19. These are the naïve R-square, naïve adjusted R-square, and the GCV (generalized cross validation) R-square. Next I move on to the summary of male and female infant mortality. The results indicate that both models perform well meaning that healthcare spending is a significant determinant of the number of deaths from treatable causes in Canada's provinces.

\section{MPYLLTC}

- $\quad$ Naïve R-Squared: 0.713

- $\quad$ Naïve adjusted R-Squared: 0.697

- GCV R-Squared: 0.604

\section{FPYLLTC}

- $\quad$ Naïve R-Squared : 0.733

- $\quad$ Naïve adjusted R-Squared : 0.714

- GCV R-Squared: 0.599

Table 19: Model Performance Measures of MARS Models Examining Deaths from Treatable Causes

Number of Infant Deaths: Variable Importance Results

The full results of the importance of each category of healthcare spending to determining the number of male and female infant deaths are summarized in Table 20. The results of the model examining female infant deaths indicate that, from highest to lowest importance, spending on 
Physicians, Drugs, Other Professionals, Hospitals and Other Health Spending are the only variables which affect female infant mortality. In the model examining male infant deaths, Other Health Spending is replaced with Public Health spending. In both models all other spending categories have a relative importance score of zero.

The first differences in relative importance scores for both models follow a fairly similar pattern. The first difference between the variables ranked first and second in each model is relatively small. The same is true for those ranked third and fourth while there is a significant difference in importance scores between the variables ranked second and third, and the variables ranked fourth and fifth. Therefore it can be said that in both models, the variables ranked first and second are relatively similar in importance as are the variables ranked third and fourth. The fifth ranked variable seems to be far less important than the other four.

\begin{tabular}{|c|c|c|}
\hline \multicolumn{3}{|c|}{ NFID } \\
\hline Variable by Rank & Relative Importance Scores & First Differences \\
\hline 1. Physicians & 100 & 0 \\
\hline 2. Drugs & 92.35 & 7.65 \\
\hline 3. Other Professionals & 73.87 & 18.48 \\
\hline 4. Hospitals & 67.97 & 5.9 \\
\hline 5. Other Health Spending & 35.05 & 32.92 \\
\hline Other Institutions & 0 & 35.05 \\
\hline Capital & 0 & 0 \\
\hline Public Health & 0 & 0 \\
\hline Administration & 0 & 0 \\
\hline Variable by Rank & $\begin{array}{c}\text { MID } \\
\text { Relative Importance Scores }\end{array}$ & First Differences \\
\hline 1. Other Professionals & 100 & 0 \\
\hline 2. Physicians & 98.82 & 1.18 \\
\hline 3. Drugs & 81.52 & 17.3 \\
\hline 4. Hospitals & 78.64 & 2.88 \\
\hline 5. Public Health & 33.42 & 45.22 \\
\hline Capital & 0 & 33.42 \\
\hline Other Institutions & 0 & 0 \\
\hline Administration & 0 & 0 \\
\hline Other Health Spending & 0 & 0 \\
\hline
\end{tabular}

Interactions between healthcare spending categories are summarized in Table $\mathbf{2 1}$. There are interactions between the top four spending categories as determined in each model. In the model examining female infant deaths there is no interaction between the Other Health Spending category and 
the other four significant spending categories. In contrast, the model examining male infant deaths indicates that the Public Health spending category has an interaction with spending on Other Professionals.

\begin{tabular}{|c|c|c|c|c|c|}
\hline \multicolumn{6}{|c|}{ MARS Model Variable Interactions for NFID } \\
\hline & Physicians & Drugs & $\begin{array}{c}\text { Other } \\
\text { Professionals }\end{array}$ & Hospitals & $\begin{array}{l}\text { Other Health } \\
\text { Spending }\end{array}$ \\
\hline Physicians & & $\checkmark$ & $\checkmark$ & $\checkmark$ & 3 \\
\hline Drugs & $\checkmark$ & & $\checkmark$ & $\checkmark$ & 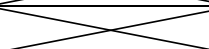 \\
\hline Other Professionals & $\checkmark$ & $\checkmark$ & & $\checkmark$ & S \\
\hline Hospitals & $\checkmark$ & $\checkmark$ & $\checkmark$ & & 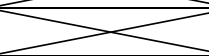 \\
\hline Other Spending & $S$ & $S$ & 3 & $>$ & \\
\hline \multicolumn{6}{|c|}{ MARS Model Variable Interactions for NMID } \\
\hline & $\begin{array}{c}\text { Other } \\
\text { Professionals }\end{array}$ & Physicians & Drugs & Hospitals & $\begin{array}{l}\text { Public } \\
\text { Health }\end{array}$ \\
\hline Other Professionals & & $\checkmark$ & $\checkmark$ & $S$ & $\checkmark$ \\
\hline Physicians & $\checkmark$ & & $\checkmark$ & $\checkmark$ & $\mathrm{S}_{\mathrm{N}}$ \\
\hline Drugs & $\checkmark$ & $\checkmark$ & & $\checkmark$ & 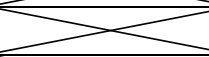 \\
\hline Hospitals & $S$ & $\checkmark$ & $\checkmark$ & & S \\
\hline Public Health & $\checkmark$ & $S$ & $S$ & 6 & \\
\hline
\end{tabular}

Table 22 summarizes the performance of each of the models examining infant mortality. The model performance measures indicate that while both models performed well, the model examining male infant deaths performed slightly better than the model examining female infant deaths. This means that healthcare spending levels can be used fairly reliably to estimate the level of infant mortality in Canada's provinces and that healthcare spending is slightly better at estimating male infant mortality than female infant mortality. I now move on to a full summary and discussion of the findings of this analysis.

- $\quad$ Naïve R-Squared: 0.737

- $\quad$ Naïve adjusted R-Squared: 0.718

- GCV R-Squared: 0.612
- $\quad$ Naïve R- Squared Measures: 0.752

- $\quad$ Naïve adjusted R-squared: 0.734

- GCV R-Squared: 0.638

Table 22: Model Performance Measures of MARS Models Examining Infant Mortality 


\section{Summary and Discussion of Findings}

This research was completed with two goals in mind. These goals were to provide evidence as to which of Canada's provinces have been most effective in their healthcare spending and to determine which categories of healthcare spending should be prioritized in improving specific health outcomes. This was achieved by modelling the efficiency of the healthcare spending in Canada's provinces and defining the categories of healthcare spending which are most significant to determining the production of health outcomes in Canada's provinces.

A review of the literature based on these criteria revealed that the theory of growth accounting provides a widely used and applicable theoretical framework for completing this research. The techniques used in this thesis were specifically selected to enable the application of this theoretical framework. These techniques were data envelopment analysis, decision tree induction, and multivariate adaptive regression splines.

Data envelopment analysis was found to be used in a number of analyses of healthcare efficiency and was selected because it facilitated the analysis of healthcare spending efficiency (Hollingsworth et al., 1999; Worthington, 2004). Decision tree induction was the other technique used to complete the analysis of spending efficiency and was primarily selected for being useful in this capacity. The technique was also selected to produce information on the importance of the independent variables used in the analysis. These two techniques were combined to construct the model for determining the effectiveness of the healthcare spending in Canada's provinces. 
The multivariate adaptive regression splines technique was selected specifically as a tool for regression analysis. In addition to being useful for regression, the technique also facilitated an analysis of the importance of the independent variables included in an analysis. The technique was utilised to define the categories of healthcare spending which are most significant to determining the production of health outcomes in Canada's provinces.

The health outcomes selected for measurement in this analysis were longevity, infant mortality and deaths from treatable causes, each being gender separated. Longevity was measured using life expectancy at birth and at age 65 , infant mortality was measured using the number of infant deaths, and deaths due to treatable causes was measured using the number of potential years of life lost due to deaths from treatable causes. The data on these measures of health outcomes were gathered for the years 1980 to 2010 for both infant mortality and deaths due to treatable causes. Life expectancy was not as readily available and so data for life expectancy was gathered for the years 1980 to 2007. Spending data was captured for the years 1980 to 2010 in terms of dollars per capita, standardized to the year 2015. Spending data was split into nine categories:

- spending on Hospitals;

- Other Health Spending;

- spending on Other Institutions;

- spending on Physicians;

- spending on Administration;

- spending on Other Professionals; 
- Public Health spending;

- Capital spending;

- $\quad$ and Drug spending.

The model used to determine the efficiency of healthcare spending among Canada's provinces consists of an application of the data envelopment analysis technique and the classification and regression trees technique. The analysis targeted each province's scale efficiency based on the ability to convert health inputs (healthcare spending) to health outcomes (life expectancy in years). The primary criteria of the analysis was whether or not each province was performing at its most productive scale size within the years examined. The secondary criteria of the analysis was whether provinces were operating at increasing returns to scale (inefficiently consuming too few resources and not producing enough longevity) or decreasing returns to scale (inefficiently consuming too many resources and not producing enough longevity).

The analysis was completed as follows. First, data envelopment analysis was applied the entire 28 years of data to model the relationship between health care spending and the production of life expectancy. This means that 280 observations on the amount of healthcare spending used to produce life expectancy in Canada's provinces were used to determine how efficiently provinces spent their healthcare funds. The results of this step were efficiency levels of the provinces, and the spending levels which indicate whether or not a province was operating at its most productive scale size. 
Next, the results of the data envelopment analysis were used in a decision tree analysis. The decision tree revealed which categories of healthcare spending were most important in deciding whether or not a province was operating at its most productive scale size. After this, a second application of data envelopment analysis was completed. In this step the dataset was analyzed year by year. Twenty-eight individual instances of data envelop analysis (one for each year) were conducted in which all 10 provinces were compared. The results of this analysis indicate which provinces performed at most productive scale size, increasing returns to scale and decreasing returns to scale in each year from 1980 to 2007. The results of this analysis will be used to answer the first research question posed in this thesis: "How effectively have Canada's provinces spent their healthcare funding?"

Finally multivariate adaptive regression splines technique was used to construct four multiple regression models; two targeting number of infant deaths (one regression model for each gender) and two targeting the number of potential years of life lost due to deaths from treatable causes (again, one regression model for each gender). The models were constructed from data from the years 1980 to 2010 which means there were 310 observations for each model. The results of the analysis indicated the categories of spending which were most important to determining the levels of infant mortality and amount of deaths from treatable causes observed in each year. These results of this analysis will be used to answer the second research question posed in this thesis: "How should spending be prioritized in order to improve health outcomes?" I now proceed with a full discussion of the findings. 


\subsubsection{The Efficient Production of Longevity}

The purpose of this analysis was to answer the first research question: "How effectively have Canada's provinces spent their healthcare funding?" In the analysis, effectiveness was measured in terms of how efficiently healthcare spending was used to produce longevity. Longevity was measured in terms of life expectancy at birth and at age 65 for both genders. This means four data envelopment analysis models were completed, one for each measure of life expectancy. Essentially, the research question was interpreted as "how efficiently have Canada's provinces produced longevity?"

The initial step of the analysis examined the entire 28 years of longevity data using data envelopment analysis. The results of this analysis can be seen in Table 11. The results indicate that provinces were operating at their most productive scale size within the "earliest" portion of the data (the segment of data from 1980 \& 1981).

For both life expectancy at age 65 and life expectancy at birth, provinces were operating at most productive scale size in 1980 . Saskatchewan was the only province to operate at most productive scale size in the year 1981. This appeared in the results of the analysis of life expectancy at age 65 for both genders. In the full results it appears that British Columbia and Manitoba were the only two provinces which didn't appear to be operating at most productive scale size. 


\begin{tabular}{|c|c|c|c|}
\hline FLE65 & FLEB & MLE65 & MLEB \\
\hline - $\quad$ Nfld 1980 & - $\quad$ Nfld 1980 & - $\quad$ Nfld 1980 & - Nfld 1980 \\
\hline - $\quad$ PEI 1980 & - $\quad$ PEI 1980 & - $\quad$ PEI 1980 & - $\quad$ PEI 1980 \\
\hline - NS 1980 & - NS 1980 & - $\quad$ NS 1980 & - NS 1980 \\
\hline - NB 1980 & - $\quad$ NB 1980 & - $\quad$ NB 1980 & - NB 1980 \\
\hline - Qc 1980 & - Qc 1980 & - $\quad$ Qc 1980 & - Qc 1980 \\
\hline - $\quad$ On 1980 & - $\quad$ On 1980 & - $\quad$ On 1980 & - $\quad$ On 1980 \\
\hline - Sk 1980 & - $\quad$ Sk 1980 & - $\quad$ Sk 1980 & - Sk 1980 \\
\hline - $A b 1980$ & - $A b 1980$ & - $\mathrm{Ab} 1980$ & - $\mathrm{Ab} 1980$ \\
\hline - $\quad$ Sk 1981 & & - Sk 1981 & \\
\hline
\end{tabular}

Table 11: List of DMUs operating at Most Productive Scale Size by Measure of Life Expectancy

These results allow us to partially answer the first research question. Based on the results, it would appear that as healthcare spending increased, the efficiency with which the provinces have been able to produce longevity has decreased. Therefore, the overall efficiency of healthcare spending in Canada's provinces has declined over time.

To understand why this occurred, we can compare the change in longevity over the time frame examined to the change in the average level of total per capita healthcare spending in each province over the same time frame. I will illustrate this point using female life expectancy at birth as an example. Table $\mathbf{2 3}$ contains data on the increase in average female life expectancy at birth in each province in Canada for the years 1980 and 2007. On average, life expectancy increased by 3.77 years in each province, which is approximately a $4.8 \%$ increase in life expectancy over 27 years. 


\begin{tabular}{|c|c|c|c|c|c|c|c|c|c|c|c|}
\hline & NL & PEI & NS & NB & Qc & On & Mn & Sk & Ab & BC & Average \\
\hline 1980 & 78.1 & 79.7 & 78.1 & 78.6 & 78.5 & 78.9 & 78.8 & 79.9 & 78.9 & 79.9 & $\mathbf{7 8 . 9}$ \\
\hline 2007 & 81.2 & 82.8 & 82.4 & 82.8 & 83.4 & 83.6 & 81.9 & 82.1 & 83.0 & 83.9 & 82.7 \\
\hline Increase & 3.1 & 3.1 & 4.3 & 4.2 & 4.9 & 4.7 & 3.1 & 2.2 & 4.1 & 4.0 & 3.77 \\
\hline Table 23: Female Life Expectancy at Birth by Province 1980 versus 2007 \\
\hline
\end{tabular}

Table 24 contains data on the increase in total per capita health care spending by province. On average total per capita healthcare spending in Canada's province increased from $\$ 906.97$ in 1980 to $\$ 4957.96$ in 2007 , which is an approximate increase of $447 \%$. It is important to note that all spending figures have been standardized to their dollar value in the year 2015. Therefore we can conclude that the average increase in life expectancy has been outpaced by the average increase per capita healthcare spending in Canada's provinces. This corroborates the results of the data envelopment analysis and reveals that over time, Canada's provinces have become less effective in their healthcare spending.

\begin{tabular}{|c|c|c|c|}
\hline Province & 1980 & 2007 & Increase \\
\hline Nfld & $\$ 922.35$ & $\$ 5030.33$ & $\$ 4107.98$ \\
\hline PEI & $\$ 988.59$ & $\$ 4748.57$ & $\$ 3759.98$ \\
\hline NS & $\$ 770.61$ & $\$ 5093.38$ & $\$ 4322.77$ \\
\hline NB & $\$ 796.61$ & $\$ 4993.10$ & $\$ 4196.49$ \\
\hline Qc & $\$ 904.63$ & $\$ 4357.54$ & $\$ 3452.91$ \\
\hline On & $\$ 872.92$ & $\$ 5009.50$ & $\$ 4136.58$ \\
\hline $\mathrm{Mn}$ & $\$ 938.89$ & $\$ 5281.96$ & $\$ 4343.07$ \\
\hline Sk & $\$ 843.21$ & $\$ 5116.93$ & $\$ 5273.72$ \\
\hline$A b$ & $\$ 982.07$ & $\$ 5257.25$ & $\$ 4275.18$ \\
\hline BC & $\$ 1049.85$ & $\$ 4691.05$ & $\$ 3641.20$ \\
\hline Average & $\$ 906.97$ & $\$ 4957.96$ & $\$ 4050.98$ \\
\hline
\end{tabular}


In addition to the examination of efficiency over all 28 years of available data, data envelopment analysis was used in a year by year examination of efficiency. The results indicated that, over the 28 years examined, several provinces showed instances of inefficient performance, and that the number of instances of inefficiency varied with the measure of longevity being examined (see Table 14). These results summarize the total quantity of inefficiency that occurred over the 30 years examined. As a specific example, the results indicate that Prince Edward Island had a single instance of inefficiency in the production of male life expectancy at age 65.

\begin{tabular}{|l|c|c|c|c|c|}
\hline & FLE65 & FLEB & MLE65 & MLEB & Total \\
\hline Manitoba & 16 & 16 & 19 & 16 & 67 \\
\hline Ontario & 8 & 7 & 7 & 7 & 29 \\
\hline New Brunswick & 2 & 4 & 2 & 5 & 13 \\
\hline British Columbia & 3 & 3 & 2 & 3 & 11 \\
\hline Prince Edward Island & 0 & 0 & 1 & 0 & 1 \\
\hline Total & 29 & 30 & 31 & 31 & 121 \\
\hline Table 14: Instances of Scale Inefficiency by Province and Category of Life Expectancy Estimate \\
\hline
\end{tabular}

Based on these results we can complete our answer to our first research question. Year to year, Manitoba, British Columbia, Ontario, New Brunswick and Prince Edward Island showed inefficiency in their production of longevity between 1980 and 2007. It appears that the frequency of inefficiency varied depending on the specific measure of longevity being examined and that Prince Edward Island's inefficiency was specific to a single measure of longevity (male 
life expectancy at age 65). With that being said, we can conclude that five of ten provinces in Canada showed inefficiency in their healthcare spending.

\subsubsection{Importance of Spending Categories to the Efficient Production of Longevity}

The decision tree induction technique was used on the results of the data envelopment analysis examining efficiency over the full 28 years of spending and longevity data. This analysis was performed to discover the categories of healthcare spending that are most important to determining whether or not a province efficiently produces longevity. That is, the results indicate which categories of health care spending were most influential in determining whether or not a province produced longevity with full efficiency. Through this analysis, we are able to partially answer the second research question: "How should healthcare spending be prioritized in order to improve health outcomes?"

According to the results, the importance of the spending categories in determining the efficient production of life expectancy at birth slightly differed between the analysis targeting male life expectancy at birth and the analysis targeting female life expectancy at birth. The order of importance was broken down as follows; spending on Hospitals was the most important variable for both genders and while spending on Capital and Drug spending were both determined to have no importance on the efficient production of life expectancy at birth. After this point, the results differed between the two analyses.

The results indicate that Other Health Spending was second in importance for determining the efficient production of female life expectancy at birth while the Other 
Institutions category was the third in importance. In the analysis examining male life expectancy at birth, the ranking of these categories are reversed; the Other Institutions category was second in importance for determining the efficiency with which male longevity was produced while the Other Health Spending Category was third. For both genders, the remaining categories of spending variables were ranked identically:

4. spending on Physicians;

5. spending on Administration;

6. spending on Other Professionals;

7. Public Health spending.

The results of the analysis focusing on life expectancy at age 65 indicates that the ranking of variables based on their importance to determining the efficient production of longevity at age 65 was the same for both genders. The results indicated that Drug spending was determined to have no significance. The ranking of the remaining spending categories was as follows:

1. spending on Hospitals;

2. spending on Physicians;

3. Other Health Spending;

4. spending on Other Professionals;

5. spending on Other Institutions;

6. spending on Administration;

7. Capital spending; 


\section{Public Health spending.}

These results indicate that affecting the efficient production of longevity requires that spending on Hospitals be prioritized above all other categories of healthcare spending. It also appears that spending on Drugs does not affect the efficient production of longevity in Canada's provinces. The other categories of healthcare affect the efficient production of longevity differently depending on whether one is targeting the efficient production of life expectancy at age 65 , or the efficient production of life expectancy at birth. Further, gender should be considered when attempting to affect life expectancy at birth as there is a slight difference in how the two categories of healthcare spending should be prioritized when focusing on either male life expectancy at birth or female life expectancy at birth.

\subsubsection{The Causes of Inefficiency}

One question raised by these results is "What caused these provinces to perform inefficiently? "Identifying the source of the observed inefficiency in a province requires an examination of that province's spending patterns in comparison to the variable importance results. To illustrate I will use Prince Edward Island which had a single instance of performing at increasing returns to scale in the year 1991 within the analysis of male life expectancy at age 65. Table $\mathbf{2 5}$ contains a summary of the data on male life expectancy at age 65 and per capita health spending by category for Prince Edward Island in the year 1991.

Prince Edward Island was found to be operating at increasing returns to scale in the year

1991. A province operating at increasing returns to scale in the production of longevity is 
inefficient because the province is not spending enough on healthcare to produce longevity at its most productive scale size. Therefore Prince Edward Island did not spend enough on healthcare in the year 1991 to produce male life expectancy at age 65 at the province's most productive scale size. For a province operating at increasing returns to scale to operate at its most productive scale size in the production of longevity, it would need to spend more on healthcare. We can suggest changes hypothetical changes to Prince Edward Island's spending in 1991 order to have the province operate at its most productive scale size in the production of male life expectancy at age 65 . To make suggestions as to how changes to healthcare spending should be prioritized requires two steps. First we will examine the ranking of spending categories produced in the previous analysis. Second we will examine the spending

\begin{tabular}{|c|c|}
\hline LONGEVITY AND SPENDING CATEGORIES & VALUE IN 1991 \\
\hline MALE LIFE EXPECTANCY AT AGE 65 & 14.3 Years \\
\hline HOSPITALS & $\$ 837.5$ \\
\hline PHYSICIANS & $\$ 241.14$ \\
\hline OTHER HEALTH SPENDING & $\$ 83.14$ \\
\hline OTHER PROFESSIONALS & $\$ 198.94$ \\
\hline OTHER INSTITUTIONS & $\$ 301.71$ \\
\hline ADMINISTRATION & $\$ 46.93$ \\
\hline CAPITAL & $\$ 65.36$ \\
\hline PUBLIC HEALTH & $\$ 80.65$ \\
\hline DRUGS & $\$ 298.14$ \\
\hline
\end{tabular}

I reiterate that the variable importance results are significant here because they indicate which categories of spending are most important in determining whether or not a province was efficiently producing longevity over the 28 years examined using data envelopment analysis. The variable importance results which focused on male life expectancy at age 65 ranked the importance of each category of healthcare spending as follows: 
1. spending on Hospitals;

2. spending on Physicians;

3. Other Health Spending;

4. spending on Other Professionals;

5. spending on Other Institutions;

6. spending on Administration;

7. Capital spending;

8. Public Health spending.

Additionally the results indicate that Spending on Drugs was determined to have no importance to determining the efficient production of life expectancy at age 65.

Table 26 contains data on the provincial average level of male life expectancy at age 65 in 1991 as well as the provincial average level of per capita healthcare spending by category in 1991. We can see in Table 26 that Prince Edward Island had lower than average male life expectancy at age 65 in the year 1991. We can also see that Prince Edward Island spent less on Hospitals, Physicians, Other Health Spending, Other Professionals, Administration, Capital, and Public Health than the provincial average. As well, Prince Edward Island had higher than average per capita spending on Other Institutions and Drugs than the provincial average.

Of the categories of healthcare spending that significantly impact the efficient production of male life expectancy at age 65, spending on Other Institutions was the only category in which Prince Edward Island appeared to have a higher than average level of spending. In contrast, we can see that while spending on Drugs was found to have no 
significance in determining the efficient production of male life expectancy at age 65, Prince Edward Island spent more than the provincial average on Drugs in 1991 . These results demonstrate the exact source of inefficiency in Prince Edward Island's production of male life expectancy.

\begin{tabular}{|c|c|c|c|}
$\begin{array}{c}\text { LONGEVITY AND } \\
\text { SPENDING CATEGORIES }\end{array}$ & $\begin{array}{c}\text { PROVINCIAL AVERAGE } \\
\text { IN 1991 }\end{array}$ & $\begin{array}{c}\text { PRINCE EDWARD } \\
\text { ISLAND IN 1991 }\end{array}$ & DIFFERENCE \\
\hline $\begin{array}{c}\text { MALE LIFE EXPECTANCY } \\
\text { AT AGE 65 }\end{array}$ & 15.62 & 14.3 & 1.32 \\
\hline HOSPITALS & 882.396 & 837.5 & 44.896 \\
\hline PHYSICIANS & 295.61 & 241.14 & 54.47 \\
\hline $\begin{array}{c}\text { OTHER HEALTH } \\
\text { SPENDING }\end{array}$ & 108.32 & 83.14 & 25.18 \\
\hline OTHER PROFESSIONALS & 220.342 & 198.94 & 21.402 \\
\hline OTHER INSTITUTIONS & 266.733 & 301.71 & -34.977 \\
\hline ADMINISTRATION & 55.81 & 46.93 & 8.88 \\
\hline CAPITAL & 78.73 & 65.36 & 13.37 \\
\hline PUBLIC HEALTH & 82.99 & 80.65 & 2.34 \\
\hline DRUGS & 270.11 & 298.14 & -28.04 \\
\hline Table 26: Male Life Expectancy at age 65 and Per Capita Healthcare Spending, Prince Edward Island, 1991 \\
\hline
\end{tabular}

In a broader context, addressing the inefficient production of longevity caused by a province's healthcare spending is a question of specific policy. Within this example, we can discuss the possible levels of spending that would have hypothetically caused Prince Edward Island to produce male life expectancy at age 65 at its most productive scale size for the year 1991. However though the source of inefficiency is corroborated by the spending figures, other factors may have played a role in lowering the life expectancy observed in the province. The data envelopment analysis technique provides a method of examining how the provinces should have produced longevity given the resources that they consumed, however beyond a technical analysis, the method doesn't necessarily allow for assumptions to be made as to how policy should be changed to improve efficiency. These limitations will be discussed in more detail at a later point. With that being said, I now move on to discussing the results of the analysis of infant mortality and deaths due to treatable causes. 


\subsubsection{The Importance of Spending to Determining Non-Longevity Health Outcomes}

The multivariate adaptive regression splines technique was used to analyse the relationship between healthcare spending and two specific health outcomes in Canada's provinces: infant mortality and deaths due to treatable causes. These analyses were conducted using data from 1980 to 2010 to examine the importance of healthcare spending to determining specific health outcomes. In the analysis, the number deaths due to treatable causes were represented using the number of potential years of life lost from deaths due to treatable causes while infant mortality was examined using the number of infant deaths. Two regression analyses were conducted for the analysis deaths due to treatable causes; one targeting male deaths due to treatable causes, and one targeting female deaths due to treatable causes. Two regression analyses were also conducted to model infant mortality; one targeting female infant deaths and one targeting male infant deaths. I will first discuss the findings of the analysis examining deaths due to treatable causes, following this with a discussion of the findings of the analysis examining infant mortality.

\subsubsection{The Importance of Spending to Determining Deaths due to Treatable Causes}

The results of the analysis examining deaths due to treatable causes indicate the importance of each individual healthcare spending category to determining the number of deaths due to treatable causes in a province. The results of the separate analyses examining male and female deaths from treatable causes both indicate that spending on Capital, spending on Other Institutions, spending on Administration, spending on Other Professionals and Other 
Health Spending were all determined to have no effect in determining deaths due to treatable causes. The results of the multivariate adaptive regression splines analysis examining female deaths due to treatable causes rank the rest of the healthcare spending categories as follows:

1. spending on Physicians;

2. spending on Hospitals;

3. spending and Drugs;

4. Public Health spending;

The results of the multivariate adaptive regression splines analysis ranking the importance of healthcare spending categories to determining the numbers of male deaths due to treatable causes in Canada's provinces are as follows:

1. spending on Physicians;

2. spending and Drugs;

3. spending on Hospitals;

4. Public Health spending;

We can see from these results that while deaths due to treatable causes is primarily determined by four categories of healthcare spending: spending on Physicians, spending on Hospitals, Drugs spending, and Public Health spending. Of these categories of healthcare spending, spending on Physicians and Public Health spending are indicated as being first and fourth in importance respectively. The results also indicate that Spending on Hospitals is more significant to determining the number of female deaths due to treatable causes while spending on drugs is more important to determining the number of male deaths due to treatable causes. 
In other words, we can conclude that spending on Hospitals is of primary importance to determining the number of deaths due to treatable causes in Canada's provinces. Additionally spending on Hospitals is slightly more important to preventing female deaths than it is to preventing male deaths in Canada's provinces. Finally, for both genders, Public Health Spending is fourth in terms of relevance to determining preventable deaths in Canada's provinces while spending on Capital, spending on Other Institutions, spending on Administration, spending on Other Professionals and Other Health Spending have no effect in determining deaths due to treatable causes. In both models, all other categories of spending have at least one interaction with each other. Based on these rankings I conclude that spending on Physicians is a primary determinant of the number of deaths due to treatable causes in Canada's provinces.

As a result of the analysis of deaths from treatable causes, data on two-way interactions between spending categories was generated. These results indicate the categories of healthcare spending which interacted with each other in the determination of deaths due to treatable causes. The results indicate that all for both male and female deaths due to treatable causes, spending on Hospitals and spending on Physicians had no interactions with each other. According to the results, these two categories of healthcare both contribute to determining the number of male and female deaths from treatable causes but do not affect each other. All other categories of healthcare spending that were determined to be significant in determining deaths from treatable causes interacted with each other. I now move on to discuss the results of the analysis of infant mortality. 


\subsubsection{The Importance of Spending to Determining Infant Mortality}

The results of the analysis of infant mortality indicate the importance of each category

of healthcare spending to determining the level of infant mortality in each of Canada's provinces. I will begin by examining female infant mortality. The results of the multivariate adaptive regression splines analysis of the number of female infant deaths indicate that spending on Other Institutions, spending on Capital, spending on Public Health, and spending on Administration all had no importance to determining the number of female infant deaths in Canada's provinces. The remaining categories of spending were ranked as follows:

1. spending on Physicians;

2. spending on Drugs;

3. spending on Other Professionals;

4. spending on Hospitals;

5. Other Health Spending.

The results of the analysis of male infant mortality indicate that spending on Capital, spending on Other Institutions, spending on Administration and Other Health Spending all had no significance in determining the number of male infant deaths in Canada's provinces. According to the results, the ranking of the remaining five categories of healthcare spending was as follows:

1. spending on Other Professionals;

2. spending on Physicians;

3. spending on Drugs; 


\section{4. spending on Hospitals;}

5. Public Health spending.

Based on these findings, we can conclude that in Canada's provinces, male and female infant mortality are determined by two similar but slightly different sets of categories of healthcare spending. Male infant mortality is determined by spending on Other Professionals, spending on Physicians, spending on Drugs, spending on Hospitals and Public Health spending. Female infant mortality is determined by spending on Physicians, spending on Drugs, spending on Other Professionals, spending on Hospitals, and Other Health Spending. It appears that spending on Physicians ranked first in determining female infant mortality and second in determining male infant mortality. Therefore I conclude that spending on Physicians is a primary determinant of infant mortality in Canada's provinces. I will now proceed to discuss the contribution of healthcare spending to the prediction of healthcare outcomes.

Table 21 below summarizes the results of the interaction of spending categories in the determination of male and female infant mortality. The results of the analysis of female infant deaths indicates that the Other Health Spending category did not affect any other of the five other categories of healthcare spending which are significant to determining female infant mortality.

The results of the analysis of male infant deaths indicate that Public Health Spending only interacts with spending on Other Professionals in determining infant mortality. Additionally there is no interaction between spending on Hospitals and spending on Physicians in the determination of male infant mortality. Other than these exceptions, there are two-way 
interactions between all of the categories of healthcare spending which are significant to determining male infant mortality in Canada's provinces. 


\begin{tabular}{|c|c|c|c|c|c|}
\hline \multicolumn{6}{|c|}{ MARS Model Variable Interactions for NFID } \\
\hline & Physicians & Drugs & $\begin{array}{c}\text { Other } \\
\text { Professionals }\end{array}$ & Hospitals & $\begin{array}{c}\text { Other Health } \\
\text { Spending }\end{array}$ \\
\hline Physicians & & $\checkmark$ & $\checkmark$ & $\sqrt{ }$ & 3 \\
\hline Drugs & $\checkmark$ & & $\checkmark$ & $\checkmark$ & $M$ \\
\hline Other Professionals & $\checkmark$ & $\checkmark$ & & $\checkmark$ & 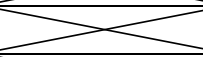 \\
\hline Hospitals & $\checkmark$ & $\checkmark$ & $\checkmark$ & & \\
\hline \multirow{2}{*}{\multicolumn{6}{|c|}{ Other Spending }} \\
\hline & & & & & \\
\hline & $\begin{array}{c}\text { Other } \\
\text { Professionals }\end{array}$ & Physicians & Drugs & Hospitals & $\begin{array}{l}\text { Public } \\
\text { Health }\end{array}$ \\
\hline Other Professionals & & $\checkmark$ & $\checkmark$ & 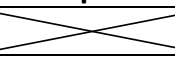 & $\checkmark$ \\
\hline Physicians & $\checkmark$ & & $\checkmark$ & $\checkmark$ & $3<$ \\
\hline Drugs & $\checkmark$ & $\checkmark$ & & $\checkmark$ & $>$ \\
\hline Hospitals & $3<$ & $\checkmark$ & $\checkmark$ & & \\
\hline Public Health & $\checkmark$ & 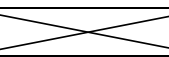 & & & \\
\hline
\end{tabular}

Table 21: Variable Interactions for MARS Models Examining Infant Mortality

\subsection{The Contribution of Spending to the Prediction of Health Outcomes}

In addition to the variable importance results, the multivariate adaptive regression splines analyses of infant mortality and deaths from treatable causes yielded results on the predictive ability of the models that were generated. In other words, the multivariate adaptive regression splines technique provides an indicator of how well the spending categories that were analysed were able to allow for the prediction of infant mortality and deaths from treatable causes. These results came in the form of the R-Squared statistics for each of the models that were generated. Each R-Squared statistics provides an indication of how well its corresponding model predicted variance in health outcome they modeled; the R-Squared statistics indicated each model's performance. An R-Squared statistic with a value of 1 would indicate that a model was perfect, while a value of 0 indicates that a model has no predictive value. As a hypothetical example, a model targeting the annual number of male infant deaths as a function of annual health care spending that reports an R-Squared statistic with a value of 
.620 indicates that annual healthcare spending is able to predict $62 \%$ of observations of the annual number of male infant deaths.

As a function of the software used in this analysis, each multivariate adaptive regression splines model yielded three R-Squared measures. Listed in order from the most relaxed to most rigorous measure of performance, these were the Naïve R-Squared, Naïve adjusted R-Squared, and GCV R-Squared. Table $\mathbf{2 7}$ contains the R-Squared statistics for each of the multivariate adaptive regression splines models generated in the analysis of infant mortality and treatable deaths.

The GCV R-Squared statistics of each model indicate a relatively high level of predictive performance for each of the models that were generated. The model examining number of female infant deaths reported a GCV R-Squared statistics of 0.638 while the model examining the number of male infant deaths reported an R-Squared statistic of 0.612 . For all four of the models, the Naïve R-Squared. The model examining female deaths from treatable causes reported a naïve R-Squared statistic of 0.599 , while the model examining male deaths from treatable causes reported a naïve R-Squared statistic of 0.604 . These scores indicate that the models perform with a relative high level of predictive ability. 


\begin{tabular}{|c|c|}
\hline Health Outcome & R-Squared Statistics \\
\hline Number of Female Infant Deaths & $\begin{array}{ll}\text { - } & \text { Naïve R-Squared: } 0.752 \\
\text { - } & \text { Naïve adjusted: } 0.734 \\
\text { - } & \text { GCV R-Squared: } 0.638\end{array}$ \\
\hline Number of Male Infant Deaths & $\begin{array}{ll}\text { - } & \text { Naïve R-Squared: } 0.737 \\
\text { - } & \text { Naïve adjusted R-Squared: } 0.718 \\
\text { - } & \text { GCV R-Squared: } 0.612\end{array}$ \\
\hline $\begin{array}{l}\text { Female Potential Years of Life Lost due to } \\
\text { Deaths from Treatable Causes }\end{array}$ & $\begin{array}{ll}\text { - } & \text { Naïve R-Squared : } 0.733 \\
\text { - } & \text { Naïve adjusted R-Squared : } 0.714 \\
\text { - } & \text { GCV R-Squared: } 0.599\end{array}$ \\
\hline $\begin{array}{l}\text { Male Potential Years of Life Lost due to Deaths } \\
\text { from Treatable Causes }\end{array}$ & $\begin{array}{l}\text { - Naïve R-Squared: } 0.713 \\
\text { - } \\
\text { - } \text { GCVIive adjusted R-Squared: } 0.697 \\
\text {-Squared: } 0.604\end{array}$ \\
\hline
\end{tabular}

The results indicate that while spending levels do not account for the entirety of the variability in either infant mortality or deaths from treatable causes, from a statistical standpoint, spending is still a powerful component in determining these health outcomes. Healthcare spending in Canada's provinces has a non-negligible effect on the health outcomes experienced by the public. I now move on to a final discussion of findings. 


\section{Discussion and Conclusion}

\subsection{Discussion}

In this chapter I discuss and interpret the findings made in this thesis. I then briefly discuss the limitations of this analysis and conclude the thesis with a discussion of possible options for future research.

The data used in this analysis indicates two trends. First, healthcare outcomes in Canada's provinces have improved over time (i.e. increased life expectancy, lower infant mortality, and fewer deaths due to treatable causes). Second, the absolute value of per capita healthcare spending has increased over time across all categories of spending and in all provinces. An analysis of this data reveals that while the improvements in health outcomes are an inarguably positive trend for the country's population, the amount of spending that has been used to achieve these improvements is inefficient.

The longitudinal analysis of spending efficiency indicates that, in the long run, healthcare spending has passed the point of producing significant improvements in health outcomes. This conclusion was demonstrated by specifically examining improvements in longevity (male and female life expectancy at birth and at age 65) over 28 years relative to increases in healthcare spending. In addition to this pattern of inefficiency, a cross-sectional, year by year analysis using the same data reveals more patterns of inefficiency amongst Canada's provinces in their production of longevity. The panel analysis revealed instances of both over and under-spending amongst provinces in different years based on specific measures of life expectancy. 
This leads to the question of why health spending continues to increase over time while efficiency suffers. Granted, we can see that health outcomes are improving, one could say that the ends do not necessarily justify the means. In a cross-country comparison of OECD member nations is, Spinks \& Hollingsworth (2009) argue that, from a political standpoint, it would be difficult for policy makers to suggest that healthcare funding be frozen or decreased without pushback. In health policy, increased healthcare spending is often linked to improved health outcomes. In reality, this isn't necessarily true. In their cross-country examination of the effect of public health spending on health outcomes, Self \& Grabowski (2003) come to an interesting conclusion. When developing countries increase health spending they tend to improve their health outcomes. In contrast, the level of positive health outcomes experienced by richer countries could be thought of as a self-perpetuating cycle. Developed countries in which healthcare outcomes are largely positive tend to retain positive health outcomes over time.

While the findings of this thesis support this conclusion, they also support the conclusion that increased spending has contributed to positive trends in health outcomes, and the conclusion that healthcare spending is a significant determinant of health outcomes in Canada's provinces. The separate analyses of infant mortality and deaths from treatable causes both indicate that per-capita health care funding makes a significant contribution to determining these two health outcomes. The exclusion of any other determinants of health outcomes in these analyses allowed for the significance of spending to be isolated. Doing this has provided evidence that healthcare spending is a major influence on health outcomes. As 
well, these findings support conclusions reached by Crémieux et al. (1999) in their analysis of the relationship between healthcare spending and health outcomes in Canada. Crémieux et al. (1999) construct a regression model that includes spending, per capita number of physicians per capita, per capita income, population density, education level, poverty rate, alcohol use, tobacco use and nutritional data. These variables are analyzed in terms of their contribution to determining gender specific infant mortality and life expectancy. The authors determine that after removing non-spending variables from the regression model, the contribution of spending to determining the examined health outcomes was still significant. The authors attribute this to their use of homogenous, Canada specific data.

This is a trait shared with the dataset analyzed in this in this thesis; the data examined here is specific to Canada. The significance of this trait of the dataset is that in international analyses, the literature indicates that healthcare spending is not as strong of a predictor of health outcomes as other variables (Or, 2000, 2001). Therefore I have elected to focus on spending variables in lieu of non-spending variables, not because non-spending variables are irrelevant, but because the analysis being performed does not lose validity due to the exclusion of non-spending variables.

With that being said, one of the original goals of this research was to determine the categories of healthcare spending that should be prioritized to improve health outcomes. The isolation of the relationship between spending and the production of health outcomes in this analysis provides an indication of the ways in which health spending should be prioritized in order to improve health outcomes. The results indicate that, in Canada, spending on Hospitals 
is the primary determinant of the efficient production of longevity. Additionally spending on Physicians appears to be a primary contributor to determining infant mortality and the number of deaths due to treatable causes in Canada's provinces. Therefore we can conclude that the improvement of health outcomes in Canada's provinces requires the prioritization of changes to spending on Hospitals and Physicians. These conclusions should be framed within the context of the findings regarding the efficient production of longevity, and the marginal improvements in longevity over the timeline examined in this thesis. In this context we can claim that while these categories of healthcare spending contribute significantly to determining health outcomes in Canada's provinces, prioritizing changes to spending on Hospitals and Physicians may only create marginal improvements in the health outcomes examined. It should be clarified that changes in the prioritization of these categories of healthcare spending do not necessarily mean spending increases. Within the context of the efficient production of longevity, it has been concluded that increases in healthcare spending are inefficiently contributing to increases in life expectancy. Therefore it is recommended that changes in healthcare spending policy should prioritize modifications that increase efficiency and that, in terms of the efficient production of longevity, Hospital spending should be prioritized.

Additionally, differences in efficient production of longevity were noted in the analysis in the specific sense that beginning of the time period examined indicated a higher level of efficiency than the later period. The increases in healthcare spending over time are constitute a significant portion of these observed differences. These spending increases are often attributed to an ageing population (Crémieux et al., 2005, 1999; Nicq et al., 2010) However, there is contention on this point with the argument being that the link between increased healthcare 
costs in countries where a larger share of the population is elderly is false (Lubitz, Cai, Kramarow, \& Lentzner, 2003; Morgan \& Cunningham, 2011; Reinhardt, 2003; Zweifel, 1999). From this standpoint, one could argue that increased healthcare spending can be attributed to attempts to sustain and increase improvements in health outcomes as a common policy of health systems. In the case of the US, administration is often pointed to as a source of rising costs. While this study does not directly address the source of increases in healthcare spending, the results of the analysis imply that these increases contribute to the inefficient production of longevity. I now move on to a discussion of limitations.

\subsection{Limitations}

The primary limitation of this research was a lack of data availability. Specifically, data was limited in the time-span it covered which kept the analysis from being completed over more time. This is with specific regard to the longevity data which was difficult to compile compared to the other health outcomes examined. These data availability issues also affected the ability of the analysis to include non-spending variables. The inclusion of data on variables such as education, diet and lifestyle would have limited the scope of the analysis. Education data (other than literacy) was particularly difficult to compile for all of the years of the study; the gaps were too large to develop a viable data set.

Relatedly, the usefulness of life expectancy as a measure of population health status is debatable (Joumard \& Häkkinen, 2007). While measures of longevity do provide information on how well health systems are able to sustain populations, they lack the qualitative component that speaks to the quality of the life that's being lived. 
Joumard \& Häkkinen (2007) argue that the best measures of health system outcomes in this framework would be quality-adjusted life-years, a measure which accounts for both longevity and quality of life. Because this measure hasn't been captured in a format which would facilitate this research I instead relied on multiple measures of healthcare outcomes. I now move on to the conclusion of this thesis.

\subsection{Conclusion}

In this conclusion I make a final reflection on the findings of this thesis, argue for the $\mathrm{m}$ model of research used in this analysis and discuss paths for future research studies. The findings of this research confirm the importance of healthcare spending as a major determinant of health outcomes. The results of the analysis of efficiency indicate that, as a developed country, improvements to longevity in Canada's provinces are likely to only be marginal as healthcare spending continues to increase over time. The research also indicates that spending on Hospitals is a major contributor to the efficient spending of longevity, and that spending on Physicians is a major contributor to the level of infant mortality and deaths from treatable causes. These findings answer the two research questions posed in the beginning of this thesis: "How effectively have Canada's provinces spent their healthcare funding?" and "How should spending be prioritized in order to improve health outcomes?"

This research analyzed data gathered using uniform methods, with all observations using standardized units of measure. Because of the homogenous nature of the dataset used in this analysis, these findings are limited to the Canadian context. I claim that this is a strength of the research rather than a limitation. In international analyses of healthcare systems which use 
blended datasets, the homogeneity of data creates inconsistencies due to differences in measurement of health outcomes. I believe that international comparisons of healthcare systems would benefit from using research models that compare the findings of multiple small studies which analyse homogenous, country-specific datasets.

Options for future research on the performance of Canada's provincial healthcare system emerge from this study. For example the inefficiency exposed within the year to year, time-series analysis of the production of longevity would benefit from investigation beyond that performed here. Analyses of policy and non-monetary factors that have contributed to the healthcare outcomes observed in the dataset would create more insight into the results observed in this thesis. However, data availability recurs as a major limiting factor in these types of studies. Longitudinal and time series analysis that include data from further into the past than the research completed here are limited by past data collection. Future studies will likely benefit from the collection of robust data from the present and later. As the economic study of healthcare continues to be a recurring issue, it is likely larger timespans than that observed here will be analysed. 


\section{$\underline{\text { Appendices }}$}

There are three appendices included in this thesis. Appendix A contains graphs and summary statistics for healthcare spending province for each of Canada's ten provinces between the years 1980

and 2010. Appendix B contains summary statistics for the healthcare outcomes examined in the empirical analysis. Appendix $\mathrm{C}$ contains an explanation for the proper interpretation of MARS model functions produced in the analysis of infant mortality and deaths from treatable causes. 
Appendix A - Summary Statistics: Health Spending by Province

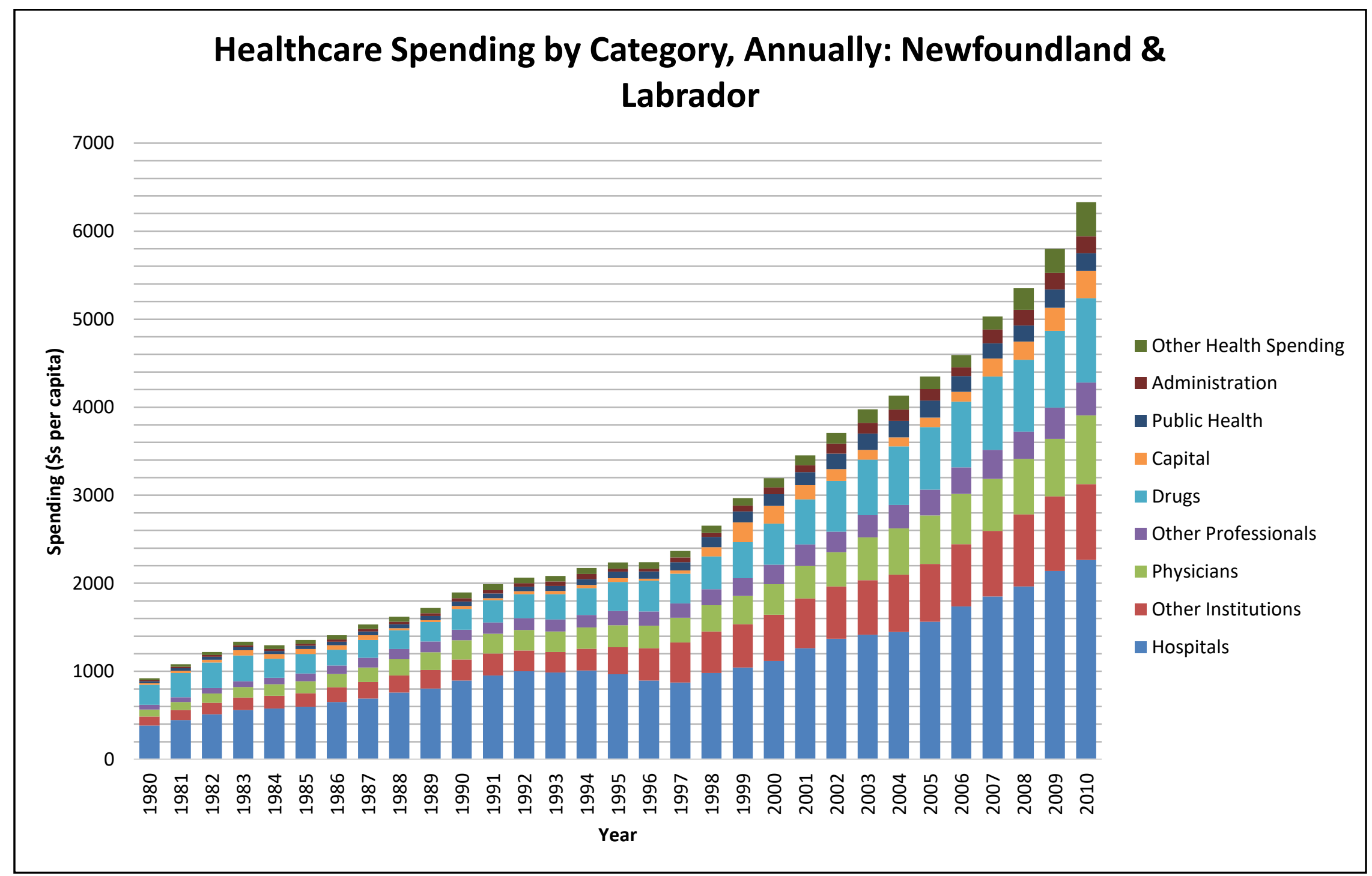

Figure 1: Healthcare Spending by Category, 1980-2010 - Newfoundland \& Labrador 


\begin{tabular}{|c|c|c|c|c|c|c|c|c|c|}
\hline \multicolumn{2}{|c|}{ Hospitals } & \multicolumn{2}{|c|}{ Other Institutions } & \multicolumn{2}{|c|}{ Physicians } & \multicolumn{2}{|c|}{ Other Professionals } & \multicolumn{2}{|c|}{ Drugs } \\
\hline Mean & 1087.97 & Mean & 400.89 & Mean & 316.75 & Mean & 179.19 & Mean & 428.06 \\
\hline $\begin{array}{l}\text { Standard } \\
\text { Error }\end{array}$ & 90.26 & $\begin{array}{l}\text { Standard } \\
\text { Error }\end{array}$ & 44.33 & $\begin{array}{l}\text { Standard } \\
\text { Error }\end{array}$ & 34.29 & $\begin{array}{l}\text { Standard } \\
\text { Error }\end{array}$ & 16.94 & $\begin{array}{l}\text { Standard } \\
\text { Error }\end{array}$ & 42.07 \\
\hline Median & 981.06 & Median & 304.72 & Median & 250.71 & Median & 161.10 & Median & 329.08 \\
\hline Mode & $\# N / A$ & Mode & $\# N / A$ & Mode & $\# N / A$ & Mode & $\# N / A$ & Mode & $\# N / A$ \\
\hline $\begin{array}{l}\text { Standard } \\
\text { Deviation }\end{array}$ & 502.57 & $\begin{array}{l}\text { Standard } \\
\text { Deviation }\end{array}$ & 246.80 & $\begin{array}{l}\text { Standard } \\
\text { Deviation }\end{array}$ & 190.90 & $\begin{array}{l}\text { Standard } \\
\text { Deviation }\end{array}$ & 94.35 & $\begin{array}{l}\text { Standard } \\
\text { Deviation }\end{array}$ & 234.21 \\
\hline $\begin{array}{c}\text { Sample } \\
\text { Variance }\end{array}$ & 252571.97 & $\begin{array}{c}\text { Sample } \\
\text { Variance }\end{array}$ & 60909.00 & $\begin{array}{c}\text { Sample } \\
\text { Variance }\end{array}$ & 36441.99 & $\begin{array}{c}\text { Sample } \\
\text { Variance }\end{array}$ & 8901.12 & $\begin{array}{c}\text { Sample } \\
\text { Variance }\end{array}$ & 54854.70 \\
\hline Kurtosis & -0.04 & Kurtosis & -1.18 & Kurtosis & -0.29 & Kurtosis & -0.87 & Kurtosis & -0.48 \\
\hline Skewness & 0.83 & Skewness & 0.49 & Skewness & 0.84 & Skewness & 0.53 & Skewness & 0.93 \\
\hline Range & 1880.96 & Range & 758.74 & Range & 703.85 & Range & 317.00 & Range & 777.04 \\
\hline Minimum & 384.32 & Minimum & 102.91 & Minimum & 78.22 & Minimum & 54.50 & Minimum & 180.75 \\
\hline Maximum & 2265.28 & Maximum & 861.65 & Maximum & 782.07 & Maximum & 371.50 & Maximum & 957.79 \\
\hline Sum & 33727.15 & Sum & 12427.51 & Sum & 9819.34 & Sum & 5554.93 & Sum & 13269.94 \\
\hline Count & 31 & Count & 31 & Count & 31 & Count & 31 & Count & 31 \\
\hline
\end{tabular}




\begin{tabular}{|c|c|c|c|c|c|c|c|}
\hline \multicolumn{2}{|c|}{ Capital } & \multicolumn{2}{|c|}{ Public Health } & \multicolumn{2}{|c|}{ Administration } & \multicolumn{2}{|c|}{ Other Health Spending } \\
\hline Mean & 93.76 & Mean & 99.87 & Mean & 69.22 & Mean & 101.36 \\
\hline Standard Error & 14.58 & Standard Error & 11.56 & Standard Error & 9.90 & Standard Error & 14.23 \\
\hline Median & 54.53 & Median & 71.95 & Median & 45.17 & Median & 71.45 \\
\hline Mode & 37.52 & Mode & $\# N / A$ & Mode & $\# N / A$ & Mode & $\# N / A$ \\
\hline $\begin{array}{l}\text { Standard } \\
\text { Deviation }\end{array}$ & 81.20 & $\begin{array}{l}\text { Standard } \\
\text { Deviation }\end{array}$ & 64.39 & $\begin{array}{l}\text { Standard } \\
\text { Deviation }\end{array}$ & 55.09 & $\begin{array}{l}\text { Standard } \\
\text { Deviation }\end{array}$ & 79.24 \\
\hline $\begin{array}{c}\text { Sample } \\
\text { Variance }\end{array}$ & 6592.88 & $\begin{array}{c}\text { Sample } \\
\text { Variance }\end{array}$ & 4145.53 & $\begin{array}{c}\text { Sample } \\
\text { Variance }\end{array}$ & 3035.40 & $\begin{array}{c}\text { Sample } \\
\text { Variance }\end{array}$ & 6279.55 \\
\hline Kurtosis & 0.43 & Kurtosis & -1.52 & Kurtosis & -0.13 & Kurtosis & 5.16 \\
\hline Skewness & 1.18 & Skewness & 0.44 & Skewness & 1.05 & Skewness & 2.12 \\
\hline Range & 292.90 & Range & 185.10 & Range & 180.25 & Range & 364.13 \\
\hline Minimum & 17.88 & Minimum & 22.15 & Minimum & 11.60 & Minimum & 23.98 \\
\hline Maximum & 310.78 & Maximum & 207.25 & Maximum & 191.85 & Maximum & 388.11 \\
\hline Sum & 2906.49 & Sum & 3095.86 & Sum & 2145.80 & Sum & 3142.04 \\
\hline Count & 31 & Count & 31 & Count & 31 & Count & 31 \\
\hline
\end{tabular}




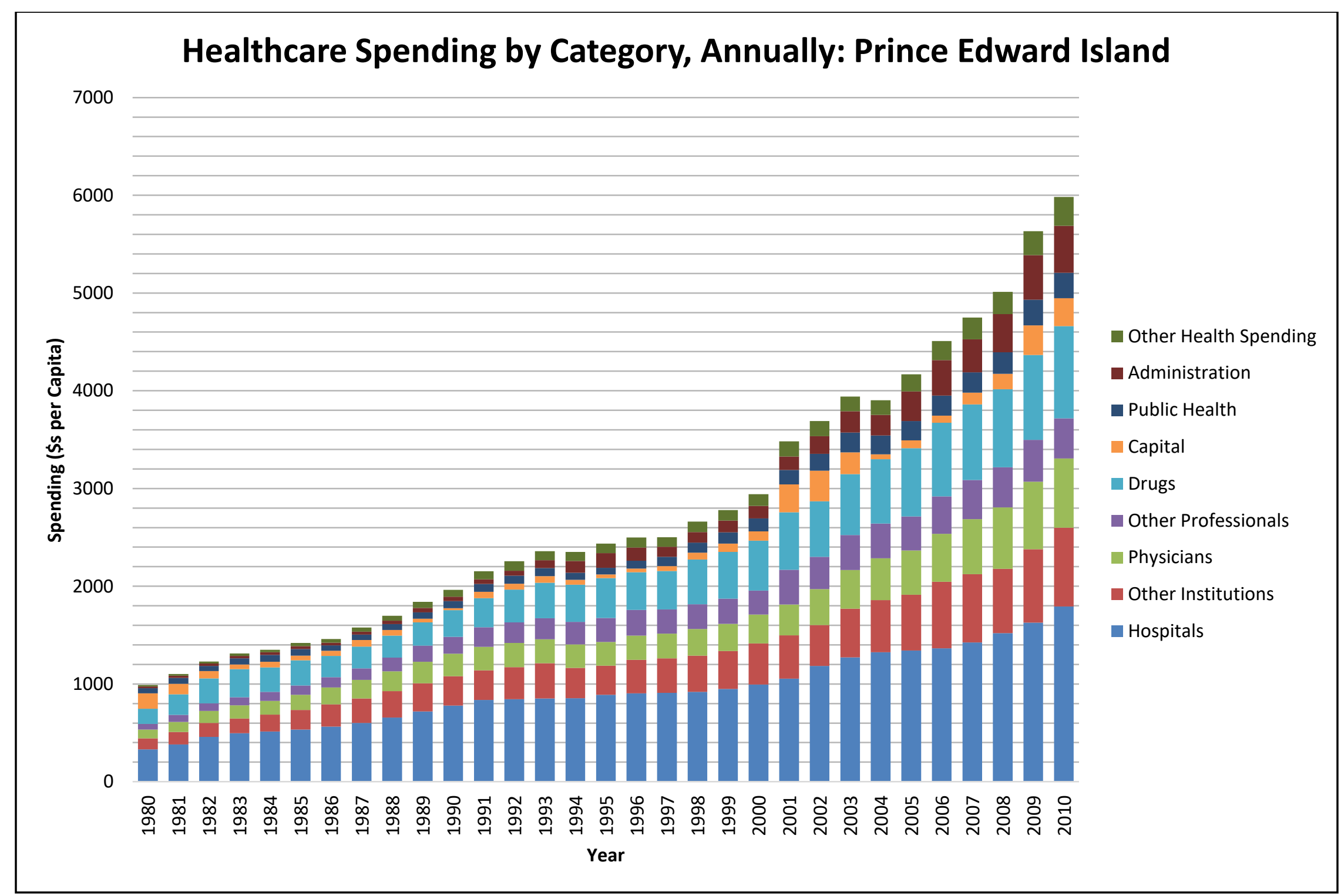

Figure 2: Healthcare Spending by Category, 1980-2010 - Prince Edward Island 


\begin{tabular}{|c|c|c|c|c|c|c|c|c|c|}
\hline \multicolumn{2}{|c|}{ Hospitals } & \multicolumn{2}{|c|}{ Other Institutions } & \multicolumn{2}{|c|}{ Physicians } & \multicolumn{2}{|c|}{ Other Professionals } & \multicolumn{2}{|c|}{ Drugs } \\
\hline Mean & 932.03 & Mean & 379.71 & Mean & 302.47 & Mean & 235.91 & Mean & 447.91 \\
\hline $\begin{array}{c}\text { Standard } \\
\text { Error }\end{array}$ & 68.44 & $\begin{array}{c}\text { Standard } \\
\text { Error }\end{array}$ & 34.02 & $\begin{array}{c}\text { Standard } \\
\text { Error }\end{array}$ & 30.19 & $\begin{array}{c}\text { Standard } \\
\text { Error }\end{array}$ & 21.05 & $\begin{array}{c}\text { Standard } \\
\text { Error }\end{array}$ & 39.94 \\
\hline Median & 887.94 & Median & 342.53 & Median & 247.87 & Median & 243.74 & Median & 386.90 \\
\hline Mode & $\# N / A$ & Mode & $\# N / A$ & Mode & $\# N / A$ & Mode & $\# N / A$ & Mode & $\# N / A$ \\
\hline $\begin{array}{l}\text { Standard } \\
\text { Deviation }\end{array}$ & 381.06 & $\begin{array}{l}\text { Standard } \\
\text { Deviation }\end{array}$ & 189.41 & $\begin{array}{l}\text { Standard } \\
\text { Deviation }\end{array}$ & 168.07 & $\begin{array}{l}\text { Standard } \\
\text { Deviation }\end{array}$ & 117.21 & $\begin{array}{l}\text { Standard } \\
\text { Deviation }\end{array}$ & 222.38 \\
\hline $\begin{array}{c}\text { Sample } \\
\text { Variance }\end{array}$ & 145203.75 & $\begin{array}{c}\text { Sample } \\
\text { Variance }\end{array}$ & 35876.81 & $\begin{array}{c}\text { Sample } \\
\text { Variance }\end{array}$ & 28246.93 & $\begin{array}{c}\text { Sample } \\
\text { Variance }\end{array}$ & 13737.47 & $\begin{array}{c}\text { Sample } \\
\text { Variance }\end{array}$ & 49452.99 \\
\hline Kurtosis & -0.49 & Kurtosis & -0.24 & Kurtosis & 0.53 & Kurtosis & -1.26 & Kurtosis & -0.63 \\
\hline Skewness & 0.47 & Skewness & 0.72 & Skewness & 1.12 & Skewness & 0.08 & Skewness & 0.71 \\
\hline Range & 1462.18 & Range & 691.36 & Range & 620.09 & Range & 368.99 & Range & 789.27 \\
\hline Minimum & 330.67 & Minimum & 113.76 & Minimum & 88.15 & Minimum & 58.23 & Minimum & 156.36 \\
\hline Maximum & 1792.85 & Maximum & 805.12 & Maximum & 708.24 & Maximum & 427.22 & Maximum & 945.63 \\
\hline Sum & 28892.79 & Sum & 11770.91 & Sum & 9376.62 & Sum & 7313.31 & Sum & 13885.20 \\
\hline Count & 31 & Count & 31 & Count & 31 & Count & 31 & Count & 31 \\
\hline
\end{tabular}




\begin{tabular}{|c|c|c|c|c|c|c|c|}
\hline \multicolumn{2}{|c|}{ Capital } & \multicolumn{2}{|c|}{ Public Health } & \multicolumn{2}{|c|}{ Administration } & \multicolumn{2}{|c|}{ Other Health Spending } \\
\hline Mean & 104.30 & Mean & 118.03 & Mean & 143.31 & Mean & 108.75 \\
\hline Standard Error & 15.48 & Standard Error & 12.12 & Standard Error & 24.64 & Standard Error & 13.24 \\
\hline Median & 67.97 & Median & 81.05 & Median & 106.34 & Median & 96.82 \\
\hline Mode & $\# N / A$ & Mode & $\# N / A$ & Mode & $\# N / A$ & Mode & $\# N / A$ \\
\hline $\begin{array}{l}\text { Standard } \\
\text { Deviation }\end{array}$ & 86.18 & $\begin{array}{l}\text { Standard } \\
\text { Deviation }\end{array}$ & 67.46 & $\begin{array}{l}\text { Standard } \\
\text { Deviation }\end{array}$ & 137.18 & $\begin{array}{l}\text { Standard } \\
\text { Deviation }\end{array}$ & 73.74 \\
\hline $\begin{array}{c}\text { Sample } \\
\text { Variance }\end{array}$ & 7426.87 & $\begin{array}{c}\text { Sample } \\
\text { Variance }\end{array}$ & 4550.89 & $\begin{array}{c}\text { Sample } \\
\text { Variance }\end{array}$ & 18817.84 & $\begin{array}{c}\text { Sample } \\
\text { Variance }\end{array}$ & 5438.08 \\
\hline Kurtosis & 1.13 & Kurtosis & -0.68 & Kurtosis & 0.45 & Kurtosis & 0.01 \\
\hline Skewness & 1.54 & Skewness & 0.88 & Skewness & 1.22 & Skewness & 0.77 \\
\hline Range & 295.24 & Range & 208.91 & Range & 464.49 & Range & 280.40 \\
\hline Minimum & 18.74 & Minimum & 52.68 & Minimum & 17.67 & Minimum & 14.33 \\
\hline Maximum & 313.98 & Maximum & 261.59 & Maximum & 482.16 & Maximum & 294.73 \\
\hline Sum & 3233.34 & Sum & 3659.06 & Sum & 4442.63 & Sum & 3371.25 \\
\hline Count & 31 & Count & 31 & Count & 31 & Count & 31 \\
\hline
\end{tabular}




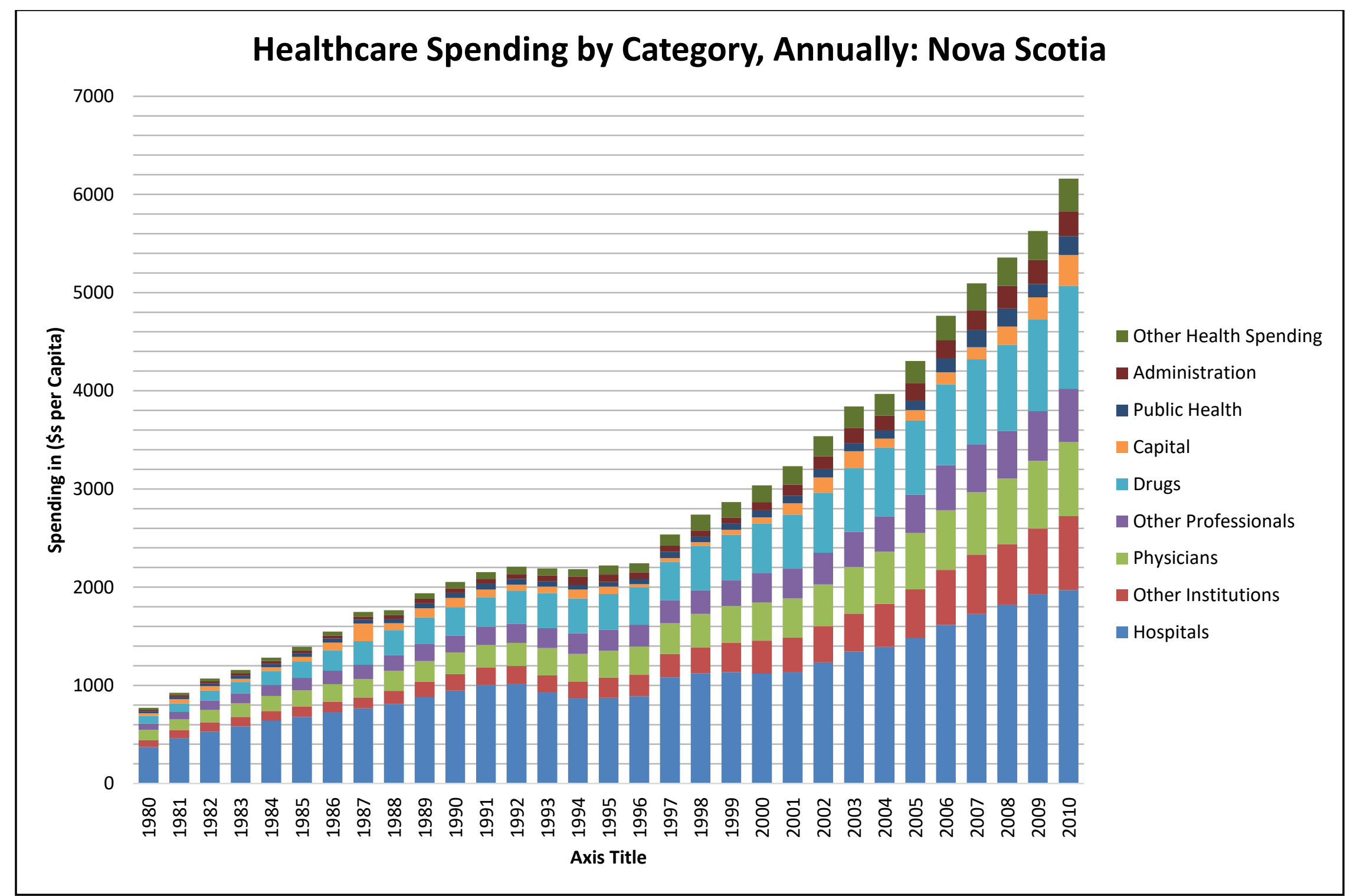

Figure 3: Healthcare Spending by Category, 1980-2010 - Nova Scotia 


\begin{tabular}{|c|c|c|c|c|c|c|c|c|c|}
\hline \multicolumn{2}{|c|}{ Hospitals } & \multicolumn{2}{|c|}{ Other Institutions } & \multicolumn{2}{|c|}{ Physicians } & \multicolumn{2}{|c|}{ Other Professionals } & \multicolumn{2}{|c|}{ Drugs } \\
\hline Mean & 1066.97 & Mean & 281.62 & Mean & 340.69 & Mean & 253.19 & Mean & 440.98 \\
\hline $\begin{array}{l}\text { Standard } \\
\text { Error }\end{array}$ & 76.36 & $\begin{array}{l}\text { Standard } \\
\text { Error }\end{array}$ & 35.15 & $\begin{array}{l}\text { Standard } \\
\text { Error }\end{array}$ & 34.11 & $\begin{array}{l}\text { Standard } \\
\text { Error }\end{array}$ & 24.57 & $\begin{array}{l}\text { Standard } \\
\text { Error }\end{array}$ & 49.37 \\
\hline Median & 1002.87 & Median & 204.15 & Median & 280.13 & Median & 216.82 & Median & 362.43 \\
\hline Mode & $\# N / A$ & Mode & $\# N / A$ & Mode & $\# N / A$ & Mode & $\# N / A$ & Mode & \#N/A \\
\hline $\begin{array}{l}\text { Standard } \\
\text { Deviation }\end{array}$ & 425.14 & $\begin{array}{l}\text { Standard } \\
\text { Deviation }\end{array}$ & 195.72 & $\begin{array}{l}\text { Standard } \\
\text { Deviation }\end{array}$ & 189.93 & $\begin{array}{l}\text { Standard } \\
\text { Deviation }\end{array}$ & 136.81 & $\begin{array}{l}\text { Standard } \\
\text { Deviation }\end{array}$ & 274.87 \\
\hline $\begin{array}{c}\text { Sample } \\
\text { Variance }\end{array}$ & 180743.66 & $\begin{array}{c}\text { Sample } \\
\text { Variance }\end{array}$ & 38308.09 & $\begin{array}{c}\text { Sample } \\
\text { Variance }\end{array}$ & 36072.84 & $\begin{array}{c}\text { Sample } \\
\text { Variance }\end{array}$ & 18717.00 & $\begin{array}{c}\text { Sample } \\
\text { Variance }\end{array}$ & 75554.96 \\
\hline Kurtosis & -0.26 & Kurtosis & -0.11 & Kurtosis & -0.60 & Kurtosis & -0.53 & Kurtosis & -0.60 \\
\hline Skewness & 0.61 & Skewness & 0.99 & Skewness & 0.74 & Skewness & 0.70 & Skewness & 0.63 \\
\hline Range & 1601.63 & Range & 682.50 & Range & 647.53 & Range & 476.43 & Range & 972.98 \\
\hline Minimum & 369.96 & Minimum & 70.62 & Minimum & 104.76 & Minimum & 67.12 & Minimum & 76.55 \\
\hline Maximum & 1971.59 & Maximum & 753.12 & Maximum & 752.29 & Maximum & 543.55 & Maximum & 1049.53 \\
\hline Sum & 33076.17 & Sum & 8730.10 & Sum & 10561.43 & Sum & 7848.83 & Sum & 13670.49 \\
\hline Count & 31 & Count & 31 & Count & 31 & Count & 31 & Count & 31 \\
\hline
\end{tabular}




\begin{tabular}{|c|c|c|c|c|c|c|c|}
\hline \multicolumn{2}{|c|}{ Capital } & \multicolumn{2}{|c|}{ Public Health } & \multicolumn{2}{|c|}{ Administration } & \multicolumn{2}{|c|}{ Other Health Spending } \\
\hline Mean & 95.16 & Mean & 72.12 & Mean & 90.88 & Mean & 129.68 \\
\hline Standard Error & 11.74 & Standard Error & 8.44 & Standard Error & 12.99 & Standard Error & 17.20 \\
\hline Median & 76.12 & Median & 56.33 & Median & 60.46 & Median & 91.89 \\
\hline Mode & $\# N / A$ & Mode & $\# N / A$ & Mode & $\# N / A$ & Mode & $\# N / A$ \\
\hline $\begin{array}{l}\text { Standard } \\
\text { Deviation }\end{array}$ & 65.35 & $\begin{array}{l}\text { Standard } \\
\text { Deviation }\end{array}$ & 47.00 & $\begin{array}{l}\text { Standard } \\
\text { Deviation }\end{array}$ & 72.33 & $\begin{array}{l}\text { Standard } \\
\text { Deviation }\end{array}$ & 95.77 \\
\hline $\begin{array}{c}\text { Sample } \\
\text { Variance }\end{array}$ & 4271.02 & $\begin{array}{c}\text { Sample } \\
\text { Variance }\end{array}$ & 2208.66 & $\begin{array}{c}\text { Sample } \\
\text { Variance }\end{array}$ & 5230.95 & $\begin{array}{c}\text { Sample } \\
\text { Variance }\end{array}$ & 9171.83 \\
\hline Kurtosis & 2.98 & Kurtosis & 1.47 & Kurtosis & -0.16 & Kurtosis & -0.97 \\
\hline Skewness & 1.62 & Skewness & 1.52 & Skewness & 1.04 & Skewness & 0.61 \\
\hline Range & 285.10 & Range & 169.98 & Range & 236.93 & Range & 316.34 \\
\hline Minimum & 27.91 & Minimum & 22.27 & Minimum & 16.07 & Minimum & 15.35 \\
\hline Maximum & 313.01 & Maximum & 192.25 & Maximum & 253.00 & Maximum & 331.69 \\
\hline Sum & 2949.92 & Sum & 2235.80 & Sum & 2817.22 & Sum & 4020.15 \\
\hline Count & 31 & Count & 31 & Count & 31 & Count & 31 \\
\hline
\end{tabular}




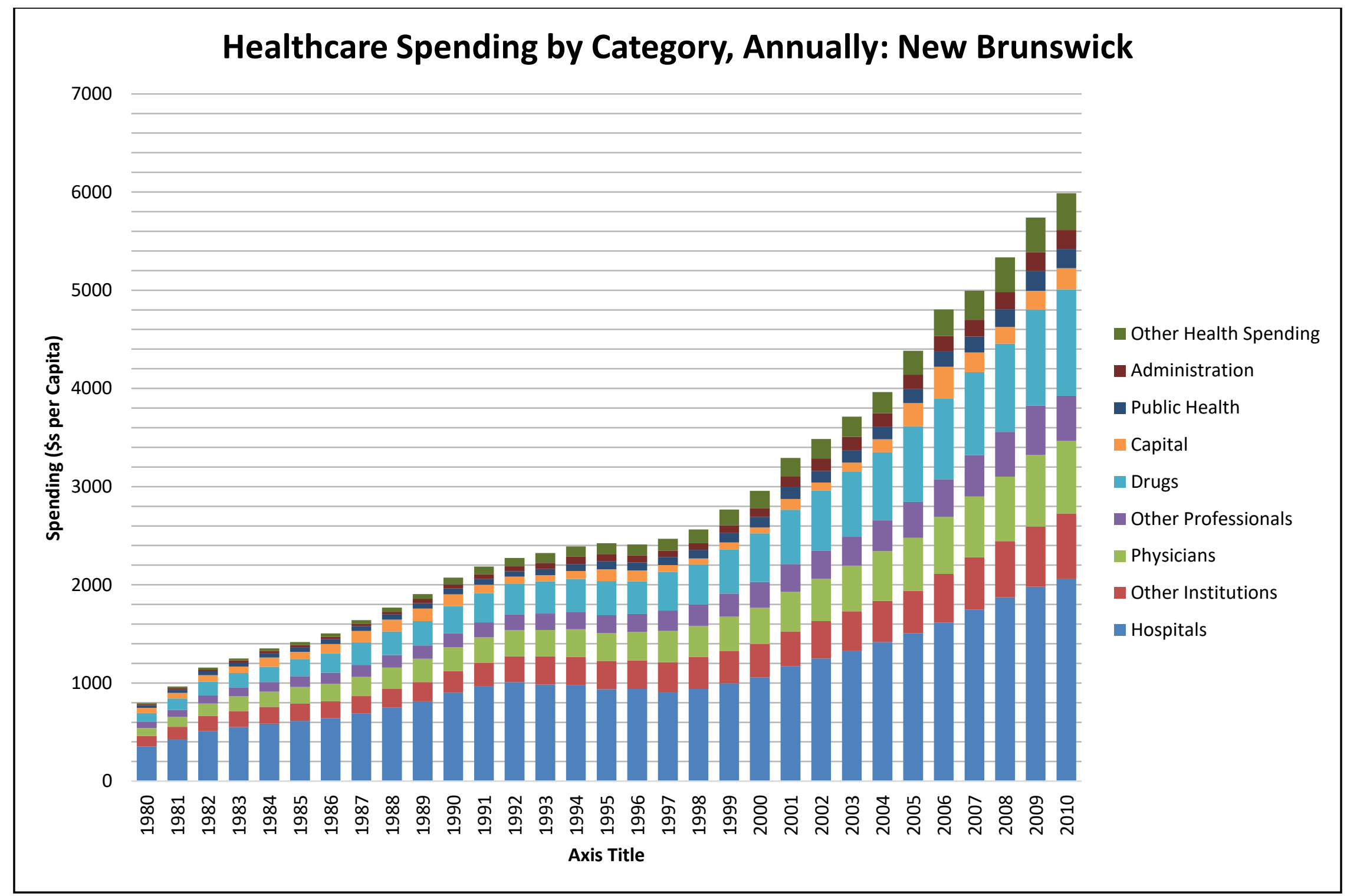

Figure 4: Healthcare Spending by Category, 1980-2010 - New Brunswick 


\begin{tabular}{|c|c|c|c|c|c|c|c|c|c|}
\hline \multicolumn{2}{|c|}{ Hospitals } & \multicolumn{2}{|c|}{ Other Institutions } & \multicolumn{2}{|c|}{ Physicians } & \multicolumn{2}{|c|}{ Other Professionals } & \multicolumn{2}{|c|}{ Drugs } \\
\hline Mean & 1048.39 & Mean & 311.85 & Mean & 340.08 & Mean & 221.18 & Mean & 439.80 \\
\hline $\begin{array}{l}\text { Standard } \\
\text { Error }\end{array}$ & 81.67 & $\begin{array}{l}\text { Standard } \\
\text { Error }\end{array}$ & 26.51 & $\begin{array}{l}\text { Standard } \\
\text { Error }\end{array}$ & 33.13 & $\begin{array}{l}\text { Standard } \\
\text { Error }\end{array}$ & 22.66 & $\begin{array}{l}\text { Standard } \\
\text { Error }\end{array}$ & 50.15 \\
\hline Median & 963.53 & Median & 289.06 & Median & 286.05 & Median & 179.98 & Median & 337.88 \\
\hline Mode & $\# N / A$ & Mode & $\# N / A$ & Mode & $\# N / A$ & Mode & $\# N / A$ & Mode & $\# N / A$ \\
\hline $\begin{array}{l}\text { Standard } \\
\text { Deviation }\end{array}$ & 454.70 & $\begin{array}{l}\text { Standard } \\
\text { Deviation }\end{array}$ & 147.59 & $\begin{array}{l}\text { Standard } \\
\text { Deviation }\end{array}$ & 184.46 & $\begin{array}{l}\text { Standard } \\
\text { Deviation }\end{array}$ & 126.18 & $\begin{array}{l}\text { Standard } \\
\text { Deviation }\end{array}$ & 279.24 \\
\hline $\begin{array}{c}\text { Sample } \\
\text { Variance }\end{array}$ & 206755.16 & $\begin{array}{c}\text { Sample } \\
\text { Variance }\end{array}$ & 21782.46 & $\begin{array}{c}\text { Sample } \\
\text { Variance }\end{array}$ & 34024.08 & $\begin{array}{c}\text { Sample } \\
\text { Variance }\end{array}$ & 15921.55 & $\begin{array}{c}\text { Sample } \\
\text { Variance }\end{array}$ & 77977.03 \\
\hline Kurtosis & -0.14 & Kurtosis & -0.06 & Kurtosis & -0.33 & Kurtosis & -0.37 & Kurtosis & -0.44 \\
\hline Skewness & 0.73 & Skewness & 0.79 & Skewness & 0.76 & Skewness & 0.81 & Skewness & 0.80 \\
\hline Range & 1708.40 & Range & 557.52 & Range & 657.91 & Range & 440.34 & Range & 993.74 \\
\hline Minimum & 354.16 & Minimum & 106.27 & Minimum & 81.80 & Minimum & 64.19 & Minimum & 88.47 \\
\hline Maximum & 2062.56 & Maximum & 663.79 & Maximum & 739.71 & Maximum & 504.53 & Maximum & 1082.21 \\
\hline Sum & 32500.22 & Sum & 9667.27 & Sum & 10542.53 & Sum & 6856.46 & Sum & 13633.88 \\
\hline Count & 31 & Count & 31 & Count & 31 & Count & 31 & Count & 31 \\
\hline
\end{tabular}




\begin{tabular}{|c|c|c|c|c|c|c|c|}
\hline \multicolumn{2}{|c|}{ Capital } & \multicolumn{2}{|c|}{ Public Health } & \multicolumn{2}{|c|}{ Administration } & \multicolumn{2}{|c|}{ Other Health Spending } \\
\hline Mean & 114.01 & Mean & 90.61 & Mean & 81.07 & Mean & 136.22 \\
\hline Standard Error & 11.25 & Standard Error & 8.92 & Standard Error & 10.42 & Standard Error & 19.59 \\
\hline Median & 95.44 & Median & 80.20 & Median & 67.88 & Median & 110.33 \\
\hline Mode & $\# N / A$ & Mode & $\# N / A$ & Mode & $\# N / A$ & Mode & $\# N / A$ \\
\hline $\begin{array}{l}\text { Standard } \\
\text { Deviation }\end{array}$ & 62.63 & $\begin{array}{l}\text { Standard } \\
\text { Deviation }\end{array}$ & 49.66 & $\begin{array}{l}\text { Standard } \\
\text { Deviation }\end{array}$ & 58.04 & $\begin{array}{l}\text { Standard } \\
\text { Deviation }\end{array}$ & 109.08 \\
\hline $\begin{array}{c}\text { Sample } \\
\text { Variance }\end{array}$ & 3921.95 & $\begin{array}{c}\text { Sample } \\
\text { Variance }\end{array}$ & 2466.30 & $\begin{array}{c}\text { Sample } \\
\text { Variance }\end{array}$ & 3368.43 & $\begin{array}{c}\text { Sample } \\
\text { Variance }\end{array}$ & 11897.37 \\
\hline Kurtosis & 3.32 & Kurtosis & -0.31 & Kurtosis & -0.94 & Kurtosis & -0.37 \\
\hline Skewness & 1.75 & Skewness & 0.85 & Skewness & 0.62 & Skewness & 0.79 \\
\hline Range & 274.28 & Range & 173.43 & Range & 182.01 & Range & 366.05 \\
\hline Minimum & 51.84 & Minimum & 28.47 & Minimum & 12.15 & Minimum & 9.26 \\
\hline Maximum & 326.12 & Maximum & 201.90 & Maximum & 194.16 & Maximum & 375.31 \\
\hline Sum & 3534.20 & Sum & 2808.87 & Sum & 2513.31 & Sum & 4222.72 \\
\hline Count & 31 & Count & 31 & Count & 31 & Count & 31 \\
\hline
\end{tabular}




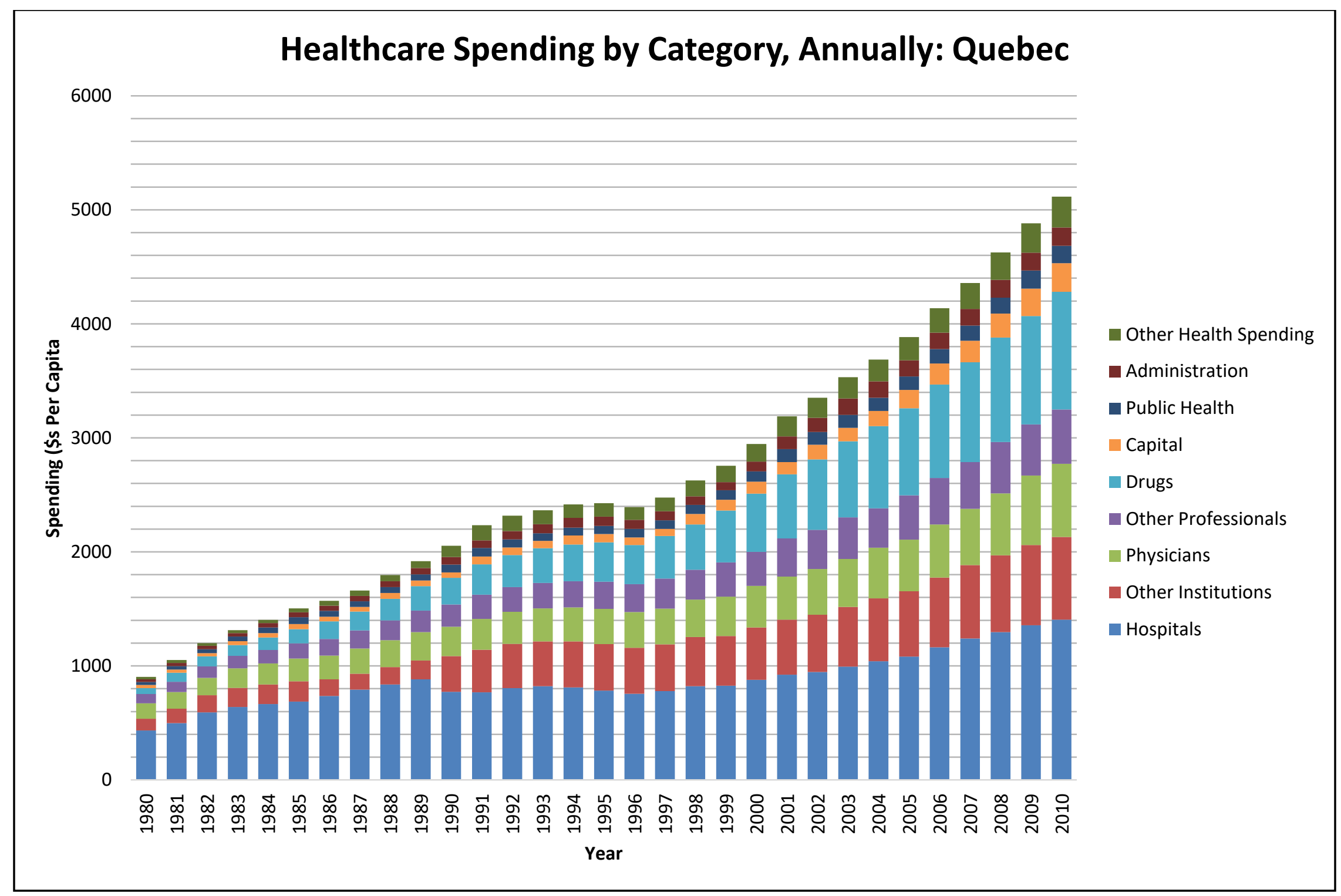

Figure 5: Healthcare Spending by Category - Quebec 


\begin{tabular}{|c|c|c|c|c|c|c|c|c|c|}
\hline \multicolumn{2}{|c|}{ Hospitals } & \multicolumn{2}{|c|}{ Other Institutions } & \multicolumn{2}{|c|}{ Physicians } & \multicolumn{2}{|c|}{ Other Professionals } & \multicolumn{2}{|c|}{ Drugs } \\
\hline Mean & 872.18 & Mean & 384.33 & Mean & 326.47 & Mean & 256.67 & Mean & 420.09 \\
\hline $\begin{array}{l}\text { Standard } \\
\text { Error }\end{array}$ & 42.12 & $\begin{array}{l}\text { Standard } \\
\text { Error }\end{array}$ & 34.33 & $\begin{array}{l}\text { Standard } \\
\text { Error }\end{array}$ & 24.00 & $\begin{array}{l}\text { Standard } \\
\text { Error }\end{array}$ & 20.84 & $\begin{array}{l}\text { Standard } \\
\text { Error }\end{array}$ & 52.95 \\
\hline Median & 821.52 & Median & 404.44 & Median & 308.30 & Median & 238.60 & Median & 342.82 \\
\hline Mode & \#N/A & Mode & \#N/A & Mode & $\# N / A$ & Mode & $\# N / A$ & Mode & $\# N / A$ \\
\hline $\begin{array}{l}\text { Standard } \\
\text { Deviation }\end{array}$ & 234.52 & $\begin{array}{l}\text { Standard } \\
\text { Deviation }\end{array}$ & 191.16 & $\begin{array}{l}\text { Standard } \\
\text { Deviation }\end{array}$ & 133.63 & $\begin{array}{l}\text { Standard } \\
\text { Deviation }\end{array}$ & 116.02 & $\begin{array}{l}\text { Standard } \\
\text { Deviation }\end{array}$ & 294.79 \\
\hline $\begin{array}{c}\text { Sample } \\
\text { Variance }\end{array}$ & 54999.59 & $\begin{array}{c}\text { Sample } \\
\text { Variance }\end{array}$ & 36542.09 & $\begin{array}{c}\text { Sample } \\
\text { Variance }\end{array}$ & 17856.54 & $\begin{array}{c}\text { Sample } \\
\text { Variance }\end{array}$ & 13460.95 & $\begin{array}{c}\text { Sample } \\
\text { Variance }\end{array}$ & 86901.32 \\
\hline Kurtosis & 0.27 & Kurtosis & -1.12 & Kurtosis & -0.09 & Kurtosis & -0.99 & Kurtosis & -0.82 \\
\hline Skewness & 0.66 & Skewness & 0.05 & Skewness & 0.67 & Skewness & 0.27 & Skewness & 0.65 \\
\hline Range & 971.99 & Range & 620.84 & Range & 506.98 & Range & 395.35 & Range & 979.58 \\
\hline Minimum & 434.40 & Minimum & 103.51 & Minimum & 134.25 & Minimum & 80.52 & Minimum & 52.49 \\
\hline Maximum & 1406.39 & Maximum & 724.35 & Maximum & 641.23 & Maximum & 475.87 & Maximum & 1032.07 \\
\hline Sum & 27037.58 & Sum & 11914.34 & Sum & 10120.44 & Sum & 7956.79 & Sum & 13022.72 \\
\hline Count & 31 & Count & 31 & Count & 31 & Count & 31 & Count & 31 \\
\hline
\end{tabular}




\begin{tabular}{|c|c|c|c|c|c|c|c|}
\hline \multicolumn{2}{|c|}{ Capital } & \multicolumn{2}{|c|}{ Public Health } & \multicolumn{2}{|c|}{ Administration } & \multicolumn{2}{|c|}{ Other Health Spending } \\
\hline Mean & 94.37 & Mean & 82.44 & Mean & 85.96 & Mean & 125.73 \\
\hline Standard Error & 11.52 & Standard Error & 6.55 & Standard Error & 7.95 & Standard Error & 13.65 \\
\hline Median & 70.50 & Median & 74.45 & Median & 78.84 & Median & 122.23 \\
\hline Mode & $\# N / A$ & Mode & 50.32 & Mode & $\# N / A$ & Mode & $\# N / A$ \\
\hline $\begin{array}{l}\text { Standard } \\
\text { Deviation }\end{array}$ & 64.13 & $\begin{array}{l}\text { Standard } \\
\text { Deviation }\end{array}$ & 36.45 & $\begin{array}{l}\text { Standard } \\
\text { Deviation }\end{array}$ & 44.28 & $\begin{array}{l}\text { Standard } \\
\text { Deviation }\end{array}$ & 76.01 \\
\hline $\begin{array}{c}\text { Sample } \\
\text { Variance }\end{array}$ & 4112.41 & $\begin{array}{c}\text { Sample } \\
\text { Variance }\end{array}$ & 1328.45 & $\begin{array}{c}\text { Sample } \\
\text { Variance }\end{array}$ & 1960.90 & $\begin{array}{c}\text { Sample } \\
\text { Variance }\end{array}$ & 5777.45 \\
\hline Kurtosis & 0.34 & Kurtosis & -0.69 & Kurtosis & -1.17 & Kurtosis & -1.01 \\
\hline Skewness & 1.13 & Skewness & 0.49 & Skewness & 0.39 & Skewness & 0.19 \\
\hline Range & 223.88 & Range & 132.28 & Range & 136.87 & Range & 250.26 \\
\hline Minimum & 27.75 & Minimum & 26.63 & Minimum & 23.32 & Minimum & 21.62 \\
\hline Maximum & 251.63 & Maximum & 158.91 & Maximum & 160.19 & Maximum & 271.88 \\
\hline Sum & 2925.57 & Sum & 2555.75 & Sum & 2664.65 & Sum & 3897.55 \\
\hline Count & 31 & Count & 31 & Count & 31 & Count & 31 \\
\hline
\end{tabular}




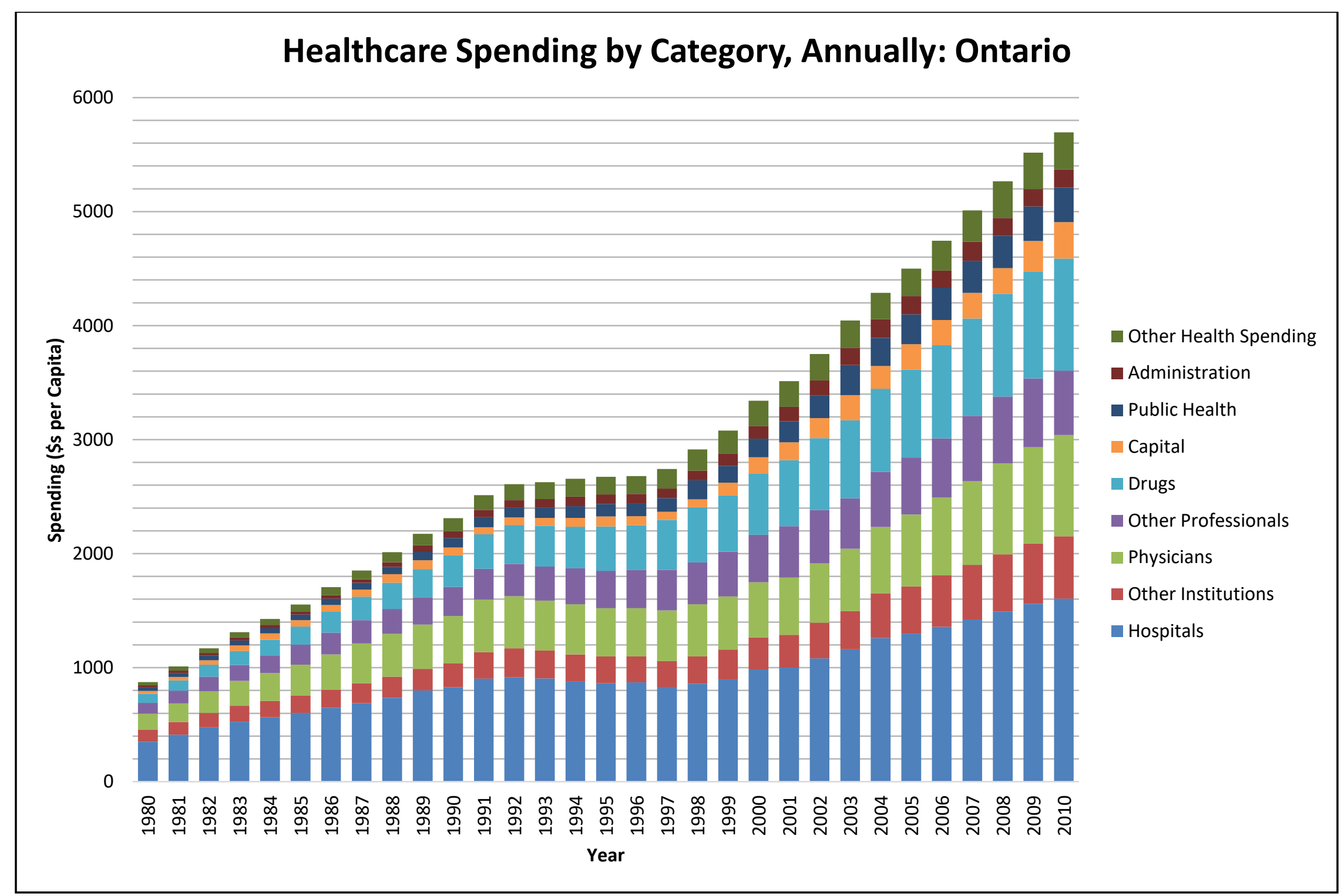

Figure 6: Healthcare Spending by Category - Ontario 


\begin{tabular}{|c|c|c|c|c|c|c|c|c|c|}
\hline \multicolumn{2}{|c|}{ Hospitals } & \multicolumn{2}{|c|}{ Other Institutions } & \multicolumn{2}{|c|}{ Physicians } & \multicolumn{2}{|c|}{ Other Professionals } & \multicolumn{2}{|c|}{ Drugs } \\
\hline Mean & 928.80 & Mean & 270.20 & Mean & 460.87 & Mean & 337.49 & Mean & 445.99 \\
\hline $\begin{array}{l}\text { Standard } \\
\text { Error }\end{array}$ & 60.16 & $\begin{array}{l}\text { Standard } \\
\text { Error }\end{array}$ & 22.83 & $\begin{array}{l}\text { Standard } \\
\text { Error }\end{array}$ & 34.14 & $\begin{array}{l}\text { Standard } \\
\text { Error }\end{array}$ & 27.49 & $\begin{array}{l}\text { Standard } \\
\text { Error }\end{array}$ & 49.65 \\
\hline Median & 878.86 & Median & 238.26 & Median & 445.15 & Median & 327.14 & Median & 388.72 \\
\hline Mode & $\# N / A$ & Mode & $\# N / A$ & Mode & $\# N / A$ & Mode & $\# N / A$ & Mode & \#N/A \\
\hline $\begin{array}{l}\text { Standard } \\
\text { Deviation }\end{array}$ & 334.95 & $\begin{array}{l}\text { Standard } \\
\text { Deviation }\end{array}$ & 127.11 & $\begin{array}{l}\text { Standard } \\
\text { Deviation }\end{array}$ & 190.09 & $\begin{array}{l}\text { Standard } \\
\text { Deviation }\end{array}$ & 153.04 & $\begin{array}{l}\text { Standard } \\
\text { Deviation }\end{array}$ & 276.46 \\
\hline $\begin{array}{c}\text { Sample } \\
\text { Variance }\end{array}$ & 112193.60 & $\begin{array}{c}\text { Sample } \\
\text { Variance }\end{array}$ & 16156.88 & $\begin{array}{c}\text { Sample } \\
\text { Variance }\end{array}$ & 36135.80 & $\begin{array}{c}\text { Sample } \\
\text { Variance }\end{array}$ & 23420.46 & $\begin{array}{c}\text { Sample } \\
\text { Variance }\end{array}$ & 76429.11 \\
\hline Kurtosis & -0.45 & Kurtosis & -0.26 & Kurtosis & 0.06 & Kurtosis & -1.11 & Kurtosis & -0.97 \\
\hline Skewness & 0.40 & Skewness & 0.86 & Skewness & 0.49 & Skewness & 0.16 & Skewness & 0.48 \\
\hline Range & 1255.09 & Range & 441.38 & Range & 747.78 & Range & 508.73 & Range & 904.83 \\
\hline Minimum & 350.82 & Minimum & 105.53 & Minimum & 140.36 & Minimum & 95.51 & Minimum & 77.50 \\
\hline Maximum & 1605.91 & Maximum & 546.91 & Maximum & 888.14 & Maximum & 604.24 & Maximum & 982.33 \\
\hline Sum & 28792.67 & Sum & 8376.30 & Sum & 14287.08 & Sum & 10462.14 & Sum & 13825.70 \\
\hline Count & 31 & Count & 31 & Count & 31 & Count & 31 & Count & 31 \\
\hline
\end{tabular}




\begin{tabular}{|c|c|c|c|c|c|c|c|}
\hline \multicolumn{2}{|c|}{ Capital } & \multicolumn{2}{|c|}{ Public Health } & \multicolumn{2}{|c|}{ Administration } & \multicolumn{2}{|c|}{ Other Health Spending } \\
\hline Mean & 118.16 & Mean & 141.26 & Mean & 87.76 & Mean & 163.13 \\
\hline Standard Error & 14.56 & Standard Error & 16.72 & Standard Error & 9.25 & Standard Error & 16.21 \\
\hline Median & 75.86 & Median & 109.56 & Median & 83.25 & Median & 156.12 \\
\hline Mode & $\# N / A$ & Mode & $\# N / A$ & Mode & $\# N / A$ & Mode & $\# N / A$ \\
\hline $\begin{array}{l}\text { Standard } \\
\text { Deviation }\end{array}$ & 81.09 & $\begin{array}{l}\text { Standard } \\
\text { Deviation }\end{array}$ & 93.09 & $\begin{array}{l}\text { Standard } \\
\text { Deviation }\end{array}$ & 51.51 & $\begin{array}{l}\text { Standard } \\
\text { Deviation }\end{array}$ & 90.26 \\
\hline $\begin{array}{c}\text { Sample } \\
\text { Variance }\end{array}$ & 6575.20 & $\begin{array}{c}\text { Sample } \\
\text { Variance }\end{array}$ & 8665.70 & $\begin{array}{c}\text { Sample } \\
\text { Variance }\end{array}$ & 2652.84 & $\begin{array}{c}\text { Sample } \\
\text { Variance }\end{array}$ & 8147.41 \\
\hline Kurtosis & -0.34 & Kurtosis & -1.18 & Kurtosis & -1.41 & Kurtosis & -1.03 \\
\hline Skewness & 0.94 & Skewness & 0.58 & Skewness & 0.23 & Skewness & 0.18 \\
\hline Range & 293.61 & Range & 273.74 & Range & 147.99 & Range & 296.34 \\
\hline Minimum & 25.79 & Minimum & 30.53 & Minimum & 18.86 & Minimum & 28.02 \\
\hline Maximum & 319.40 & Maximum & 304.27 & Maximum & 166.85 & Maximum & 324.36 \\
\hline Sum & 3662.90 & Sum & 4378.99 & Sum & 2720.51 & Sum & 5057.06 \\
\hline Count & 31 & Count & 31 & Count & 31 & Count & 31 \\
\hline
\end{tabular}




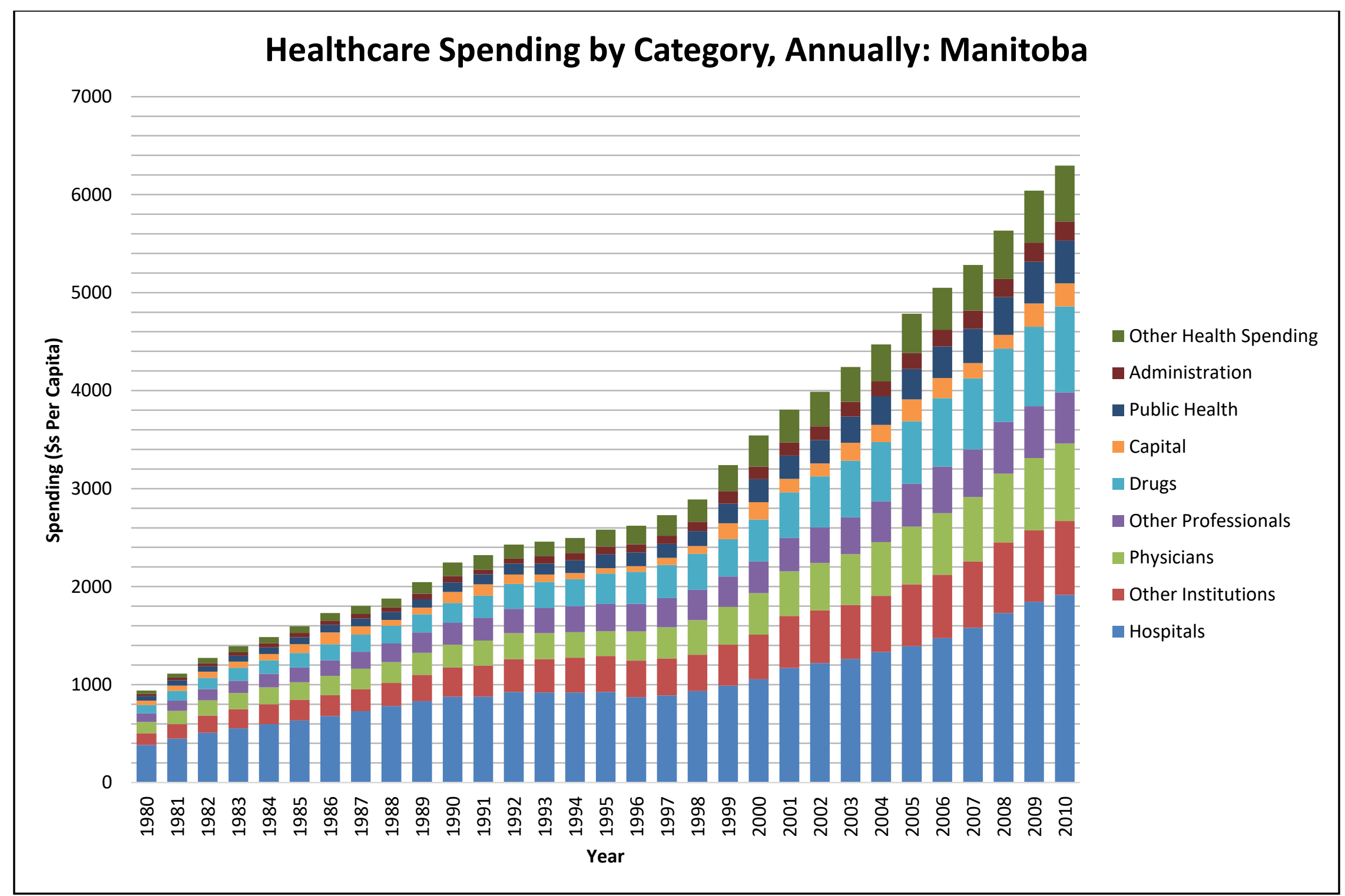

Figure 7: Healthcare Spending by Category - Manitoba 


\begin{tabular}{|c|c|c|c|c|c|c|c|c|c|}
\hline \multicolumn{2}{|c|}{ Hospitals } & \multicolumn{2}{|c|}{ Other Institutions } & \multicolumn{2}{|c|}{ Physicians } & \multicolumn{2}{|c|}{ Other Professionals } & \multicolumn{2}{|c|}{ Drugs } \\
\hline Mean & 1008.13 & Mean & 398.12 & Mean & 360.88 & Mean & 288.73 & Mean & 370.07 \\
\hline $\begin{array}{l}\text { Standard } \\
\text { Error }\end{array}$ & 71.97 & $\begin{array}{l}\text { Standard } \\
\text { Error }\end{array}$ & 33.95 & $\begin{array}{l}\text { Standard } \\
\text { Error }\end{array}$ & 35.40 & $\begin{array}{l}\text { Standard } \\
\text { Error }\end{array}$ & 23.79 & $\begin{array}{l}\text { Standard } \\
\text { Error }\end{array}$ & 42.21 \\
\hline Median & 920.29 & Median & 368.25 & Median & 265.11 & Median & 278.74 & Median & 308.90 \\
\hline Mode & \#N/A & Mode & $\# N / A$ & Mode & $\# N / A$ & Mode & $\# N / A$ & Mode & $\# N / A$ \\
\hline $\begin{array}{l}\text { Standard } \\
\text { Deviation }\end{array}$ & 400.73 & $\begin{array}{l}\text { Standard } \\
\text { Deviation }\end{array}$ & 189.02 & $\begin{array}{l}\text { Standard } \\
\text { Deviation }\end{array}$ & 197.08 & $\begin{array}{l}\text { Standard } \\
\text { Deviation }\end{array}$ & 132.45 & $\begin{array}{l}\text { Standard } \\
\text { Deviation }\end{array}$ & 234.99 \\
\hline $\begin{array}{c}\text { Sample } \\
\text { Variance }\end{array}$ & 160587.07 & $\begin{array}{c}\text { Sample } \\
\text { Variance }\end{array}$ & 35728.48 & $\begin{array}{c}\text { Sample } \\
\text { Variance }\end{array}$ & 38839.58 & $\begin{array}{c}\text { Sample } \\
\text { Variance }\end{array}$ & 17542.18 & $\begin{array}{c}\text { Sample } \\
\text { Variance }\end{array}$ & 55221.50 \\
\hline Kurtosis & -0.07 & Kurtosis & -0.97 & Kurtosis & -0.61 & Kurtosis & -0.85 & Kurtosis & -0.71 \\
\hline Skewness & 0.71 & Skewness & 0.46 & Skewness & 0.78 & Skewness & 0.38 & Skewness & 0.72 \\
\hline Range & 1531.94 & Range & 632.57 & Range & 676.89 & Range & 440.42 & Range & 792.29 \\
\hline Minimum & 383.26 & Minimum & 121.34 & Minimum & 115.03 & Minimum & 87.85 & Minimum & 84.88 \\
\hline Maximum & 1915.20 & Maximum & 753.91 & Maximum & 791.92 & Maximum & 528.27 & Maximum & 877.17 \\
\hline Sum & 31252.18 & Sum & 12341.68 & Sum & 11187.35 & Sum & 8950.73 & Sum & 11472.02 \\
\hline Count & 31 & Count & 31 & Count & 31 & Count & 31 & Count & 31 \\
\hline
\end{tabular}




\begin{tabular}{|c|c|c|c|c|c|c|c|}
\hline \multicolumn{2}{|c|}{ Capital } & \multicolumn{2}{|c|}{ Public Health } & \multicolumn{2}{|c|}{ Administration } & \multicolumn{2}{|c|}{ Other Health Spending } \\
\hline Mean & 116.12 & Mean & 177.70 & Mean & 95.71 & Mean & 229.88 \\
\hline Standard Error & 10.64 & Standard Error & 21.26 & Standard Error & 10.24 & Standard Error & 28.92 \\
\hline Median & 97.28 & Median & 138.88 & Median & 79.95 & Median & 174.50 \\
\hline Mode & $\# N / A$ & Mode & $\# N / A$ & Mode & $\# N / A$ & Mode & $\# N / A$ \\
\hline $\begin{array}{l}\text { Standard } \\
\text { Deviation }\end{array}$ & 59.23 & $\begin{array}{l}\text { Standard } \\
\text { Deviation }\end{array}$ & 118.37 & $\begin{array}{l}\text { Standard } \\
\text { Deviation }\end{array}$ & 57.03 & $\begin{array}{l}\text { Standard } \\
\text { Deviation }\end{array}$ & 161.01 \\
\hline $\begin{array}{c}\text { Sample } \\
\text { Variance }\end{array}$ & 3508.50 & $\begin{array}{c}\text { Sample } \\
\text { Variance }\end{array}$ & 14010.68 & $\begin{array}{c}\text { Sample } \\
\text { Variance }\end{array}$ & 3252.30 & $\begin{array}{c}\text { Sample } \\
\text { Variance }\end{array}$ & 25922.75 \\
\hline Kurtosis & -0.72 & Kurtosis & -0.51 & Kurtosis & -1.23 & Kurtosis & -0.84 \\
\hline Skewness & 0.70 & Skewness & 0.84 & Skewness & 0.46 & Skewness & 0.63 \\
\hline Range & 193.22 & Range & 386.83 & Range & 177.63 & Range & 534.76 \\
\hline Minimum & 44.01 & Minimum & 46.77 & Minimum & 19.91 & Minimum & 35.84 \\
\hline Maximum & 237.23 & Maximum & 433.60 & Maximum & 197.54 & Maximum & 570.60 \\
\hline Sum & 3599.64 & Sum & 5508.64 & Sum & 2966.95 & Sum & 7126.43 \\
\hline Count & 31 & Count & 31 & Count & 31 & Count & 31 \\
\hline
\end{tabular}




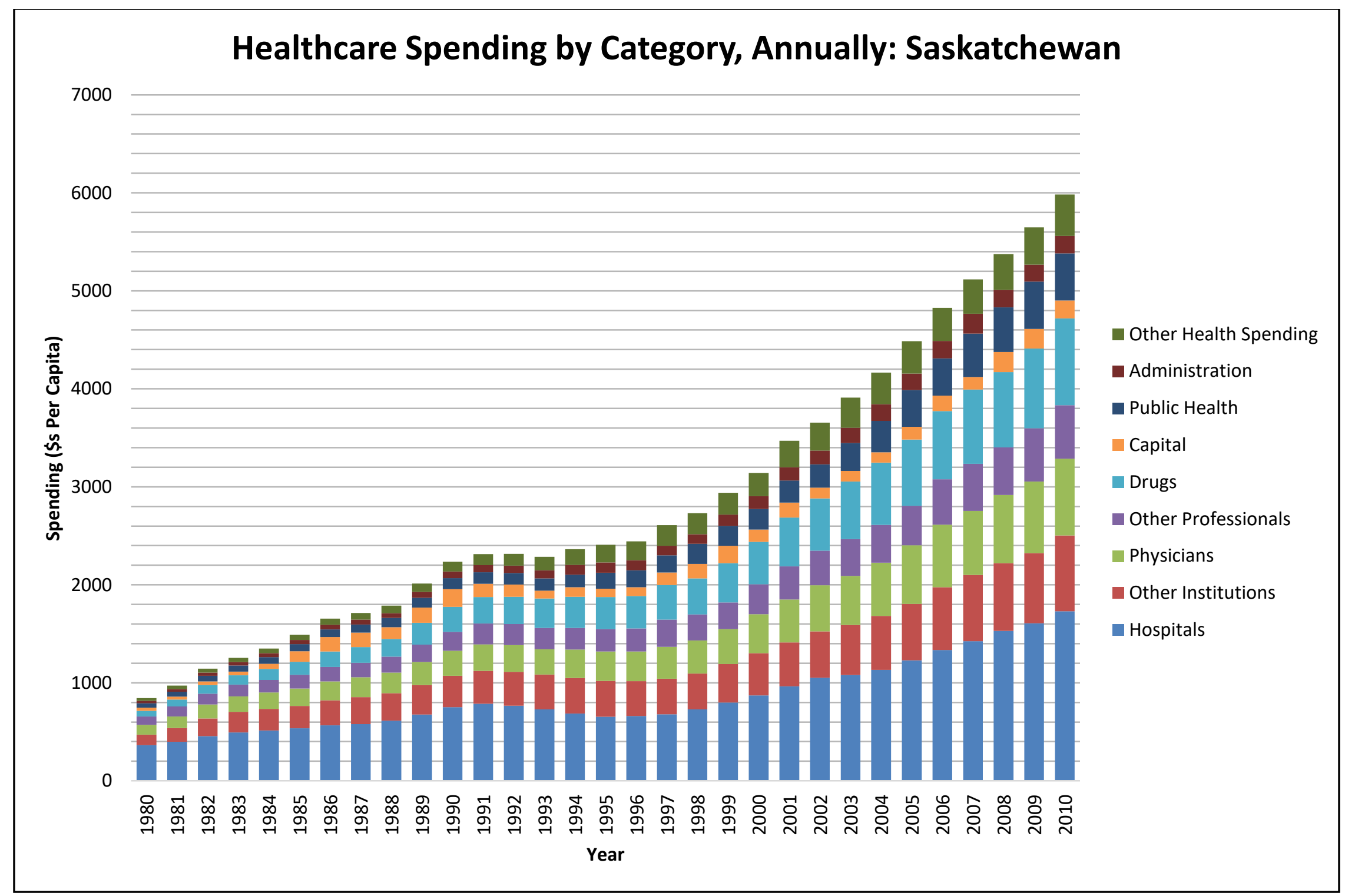

Figure 8: Healthcare Spending by Category - Saskatchewan 


\begin{tabular}{|c|c|c|c|c|c|c|c|c|c|}
\hline \multicolumn{2}{|c|}{ Hospitals } & \multicolumn{2}{|c|}{ Other Institutions } & \multicolumn{2}{|c|}{ Physicians } & \multicolumn{2}{|c|}{ Other Professionals } & \multicolumn{2}{|c|}{ Drugs } \\
\hline Mean & 851.67 & Mean & 394.77 & Mean & 359.07 & Mean & 268.68 & Mean & 379.40 \\
\hline $\begin{array}{l}\text { Standard } \\
\text { Error }\end{array}$ & 66.10 & $\begin{array}{l}\text { Standard } \\
\text { Error }\end{array}$ & 31.41 & $\begin{array}{l}\text { Standard } \\
\text { Error }\end{array}$ & 35.09 & $\begin{array}{l}\text { Standard } \\
\text { Error }\end{array}$ & 24.36 & $\begin{array}{l}\text { Standard } \\
\text { Error }\end{array}$ & 43.87 \\
\hline Median & 729.47 & Median & 363.05 & Median & 300.54 & Median & 227.40 & Median & 329.14 \\
\hline Mode & $\# N / A$ & Mode & $\# N / A$ & Mode & $\# N / A$ & Mode & $\# N / A$ & Mode & $\# N / A$ \\
\hline $\begin{array}{l}\text { Standard } \\
\text { Deviation }\end{array}$ & 368.00 & $\begin{array}{l}\text { Standard } \\
\text { Deviation }\end{array}$ & 174.87 & $\begin{array}{l}\text { Standard } \\
\text { Deviation }\end{array}$ & 195.36 & $\begin{array}{l}\text { Standard } \\
\text { Deviation }\end{array}$ & 135.63 & $\begin{array}{l}\text { Standard } \\
\text { Deviation }\end{array}$ & 244.24 \\
\hline $\begin{array}{c}\text { Sample } \\
\text { Variance }\end{array}$ & 135426.11 & $\begin{array}{c}\text { Sample } \\
\text { Variance }\end{array}$ & 30580.07 & $\begin{array}{c}\text { Sample } \\
\text { Variance }\end{array}$ & 38165.29 & $\begin{array}{c}\text { Sample } \\
\text { Variance }\end{array}$ & 18395.47 & $\begin{array}{c}\text { Sample } \\
\text { Variance }\end{array}$ & 59655.26 \\
\hline Kurtosis & 0.03 & Kurtosis & -0.37 & Kurtosis & -0.55 & Kurtosis & -0.64 & Kurtosis & -0.82 \\
\hline Skewness & 0.96 & Skewness & 0.59 & Skewness & 0.76 & Skewness & 0.65 & Skewness & 0.56 \\
\hline Range & 1367.40 & Range & 666.75 & Range & 681.26 & Range & 460.10 & Range & 828.47 \\
\hline Minimum & 363.08 & Minimum & 106.96 & Minimum & 101.76 & Minimum & 85.76 & Minimum & 56.26 \\
\hline Maximum & 1730.48 & Maximum & 773.71 & Maximum & 783.02 & Maximum & 545.86 & Maximum & 884.73 \\
\hline Sum & 26401.89 & Sum & 12237.97 & Sum & 11131.08 & Sum & 8329.18 & Sum & 11761.26 \\
\hline Count & 31 & Count & 31 & Count & 31 & Count & 31 & Count & 31 \\
\hline
\end{tabular}




\begin{tabular}{|c|c|c|c|c|c|c|c|}
\hline \multicolumn{2}{|c|}{ Capital } & \multicolumn{2}{|c|}{ Public Health } & \multicolumn{2}{|c|}{ Administration } & \multicolumn{2}{|c|}{ Other Health Spending } \\
\hline Mean & 119.97 & Mean & 197.81 & Mean & 101.06 & Mean & 187.21 \\
\hline Standard Error & 8.73 & Standard Error & 24.79 & Standard Error & 9.81 & Standard Error & 22.03 \\
\hline Median & 125.68 & Median & 163.59 & Median & 98.29 & Median & 180.54 \\
\hline Mode & $\# N / A$ & Mode & $\# N / A$ & Mode & $\# N / A$ & Mode & $\# N / A$ \\
\hline $\begin{array}{l}\text { Standard } \\
\text { Deviation }\end{array}$ & 48.60 & $\begin{array}{l}\text { Standard } \\
\text { Deviation }\end{array}$ & 138.03 & $\begin{array}{l}\text { Standard } \\
\text { Deviation }\end{array}$ & 54.61 & $\begin{array}{l}\text { Standard } \\
\text { Deviation }\end{array}$ & 122.64 \\
\hline $\begin{array}{c}\text { Sample } \\
\text { Variance }\end{array}$ & 2362.04 & $\begin{array}{c}\text { Sample } \\
\text { Variance }\end{array}$ & 19051.80 & $\begin{array}{c}\text { Sample } \\
\text { Variance }\end{array}$ & 2982.69 & $\begin{array}{c}\text { Sample } \\
\text { Variance }\end{array}$ & 15039.38 \\
\hline Kurtosis & -0.45 & Kurtosis & -0.37 & Kurtosis & -1.28 & Kurtosis & -1.25 \\
\hline Skewness & -0.30 & Skewness & 0.93 & Skewness & 0.27 & Skewness & 0.32 \\
\hline Range & 175.99 & Range & 434.88 & Range & 177.47 & Range & 395.45 \\
\hline Minimum & 29.54 & Minimum & 46.16 & Minimum & 24.16 & Minimum & 27.60 \\
\hline Maximum & 205.53 & Maximum & 481.04 & Maximum & 201.63 & Maximum & 423.05 \\
\hline Sum & 3719.09 & Sum & 6131.97 & Sum & 3132.75 & Sum & 5803.55 \\
\hline Count & 31 & Count & 31 & Count & 31 & Count & 31 \\
\hline
\end{tabular}




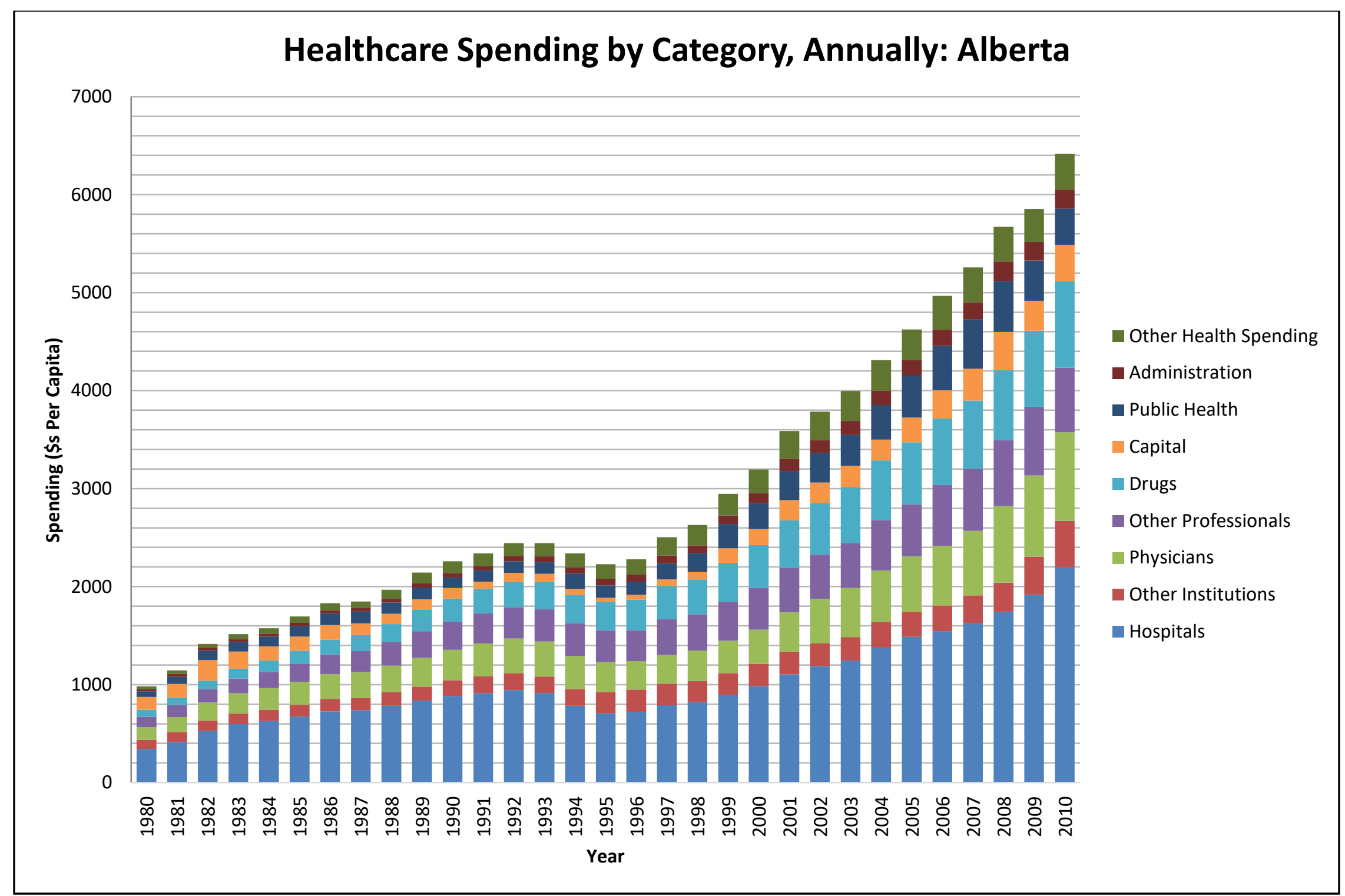

Figure 9: Healthcare Spending by Category - Alberta 


\begin{tabular}{|c|c|c|c|c|c|c|c|c|c|}
\hline \multicolumn{2}{|c|}{ Hospitals } & \multicolumn{2}{|c|}{ Other Institutions } & \multicolumn{2}{|c|}{ Physicians } & \multicolumn{2}{|c|}{ Other Professionals } & \multicolumn{2}{|c|}{ Drugs } \\
\hline Mean & 1001.93 & Mean & 202.55 & Mean & 387.34 & Mean & 363.36 & Mean & 364.93 \\
\hline $\begin{array}{l}\text { Standard } \\
\text { Error }\end{array}$ & 80.07 & $\begin{array}{l}\text { Standard } \\
\text { Error }\end{array}$ & 15.27 & $\begin{array}{l}\text { Standard } \\
\text { Error }\end{array}$ & 35.25 & $\begin{array}{l}\text { Standard } \\
\text { Error }\end{array}$ & 31.15 & $\begin{array}{l}\text { Standard } \\
\text { Error }\end{array}$ & 41.74 \\
\hline Median & 883.38 & Median & 215.98 & Median & 331.03 & Median & 327.74 & Median & 290.28 \\
\hline Mode & \#N/A & Mode & $\# N / A$ & Mode & $\# N / A$ & Mode & $\# N / A$ & Mode & $\# N / A$ \\
\hline $\begin{array}{l}\text { Standard } \\
\text { Deviation }\end{array}$ & 445.80 & $\begin{array}{l}\text { Standard } \\
\text { Deviation }\end{array}$ & 85.04 & $\begin{array}{l}\text { Standard } \\
\text { Deviation }\end{array}$ & 196.24 & $\begin{array}{l}\text { Standard } \\
\text { Deviation }\end{array}$ & 173.46 & $\begin{array}{l}\text { Standard } \\
\text { Deviation }\end{array}$ & 232.42 \\
\hline $\begin{array}{c}\text { Sample } \\
\text { Variance }\end{array}$ & 198739.27 & $\begin{array}{c}\text { Sample } \\
\text { Variance }\end{array}$ & 7232.63 & $\begin{array}{c}\text { Sample } \\
\text { Variance }\end{array}$ & 38511.98 & $\begin{array}{c}\text { Sample } \\
\text { Variance }\end{array}$ & 30089.41 & $\begin{array}{c}\text { Sample } \\
\text { Variance }\end{array}$ & 54018.43 \\
\hline Kurtosis & 0.63 & Kurtosis & 2.22 & Kurtosis & 0.92 & Kurtosis & -0.72 & Kurtosis & -0.74 \\
\hline Skewness & 1.05 & Skewness & 1.22 & Skewness & 1.23 & Skewness & 0.44 & Skewness & 0.61 \\
\hline Range & 1858.43 & Range & 377.07 & Range & 772.84 & Range & 594.50 & Range & 811.00 \\
\hline Minimum & 343.13 & Minimum & 92.79 & Minimum & 130.20 & Minimum & 106.36 & Minimum & 70.93 \\
\hline Maximum & 2201.56 & Maximum & 469.86 & Maximum & 903.04 & Maximum & 700.86 & Maximum & 881.93 \\
\hline Sum & 31059.96 & Sum & 6279.07 & Sum & 12007.51 & Sum & 11264.20 & Sum & 11312.81 \\
\hline Count & 31 & Count & 31 & Count & 31 & Count & 31 & Count & 31 \\
\hline
\end{tabular}




\begin{tabular}{|c|c|c|c|c|c|c|c|}
\hline \multicolumn{2}{|c|}{ Capital } & \multicolumn{2}{|c|}{ Public Health } & \multicolumn{2}{|c|}{ Administration } & \multicolumn{2}{|c|}{ Other Health Spending } \\
\hline Mean & 166.45 & Mean & 216.58 & Mean & 86.97 & Mean & 183.44 \\
\hline Standard Error & 16.90 & Standard Error & 25.12 & Standard Error & 10.33 & Standard Error & 20.41 \\
\hline Median & 145.40 & Median & 133.71 & Median & 69.20 & Median & 146.57 \\
\hline Mode & \#N/A & Mode & $\# N / A$ & Mode & $\# N / A$ & Mode & $\# N / A$ \\
\hline $\begin{array}{l}\text { Standard } \\
\text { Deviation }\end{array}$ & 94.09 & $\begin{array}{l}\text { Standard } \\
\text { Deviation }\end{array}$ & 139.89 & $\begin{array}{l}\text { Standard } \\
\text { Deviation }\end{array}$ & 57.51 & $\begin{array}{l}\text { Standard } \\
\text { Deviation }\end{array}$ & 113.62 \\
\hline $\begin{array}{c}\text { Sample } \\
\text { Variance }\end{array}$ & 8852.96 & $\begin{array}{c}\text { Sample } \\
\text { Variance }\end{array}$ & 19568.19 & $\begin{array}{c}\text { Sample } \\
\text { Variance }\end{array}$ & 3307.77 & $\begin{array}{c}\text { Sample } \\
\text { Variance }\end{array}$ & 12908.64 \\
\hline Kurtosis & 0.10 & Kurtosis & -0.56 & Kurtosis & -0.98 & Kurtosis & -1.40 \\
\hline Skewness & 0.88 & Skewness & 0.88 & Skewness & 0.69 & Skewness & 0.28 \\
\hline Range & 352.49 & Range & 462.45 & Range & 176.09 & Range & 337.02 \\
\hline Minimum & 38.94 & Minimum & 57.32 & Minimum & 21.78 & Minimum & 29.57 \\
\hline Maximum & 391.43 & Maximum & 519.77 & Maximum & 197.87 & Maximum & 366.59 \\
\hline Sum & 5159.80 & Sum & 6713.91 & Sum & 2696.13 & Sum & 5686.66 \\
\hline Count & 31 & Count & 31 & Count & 31 & Count & 31 \\
\hline
\end{tabular}




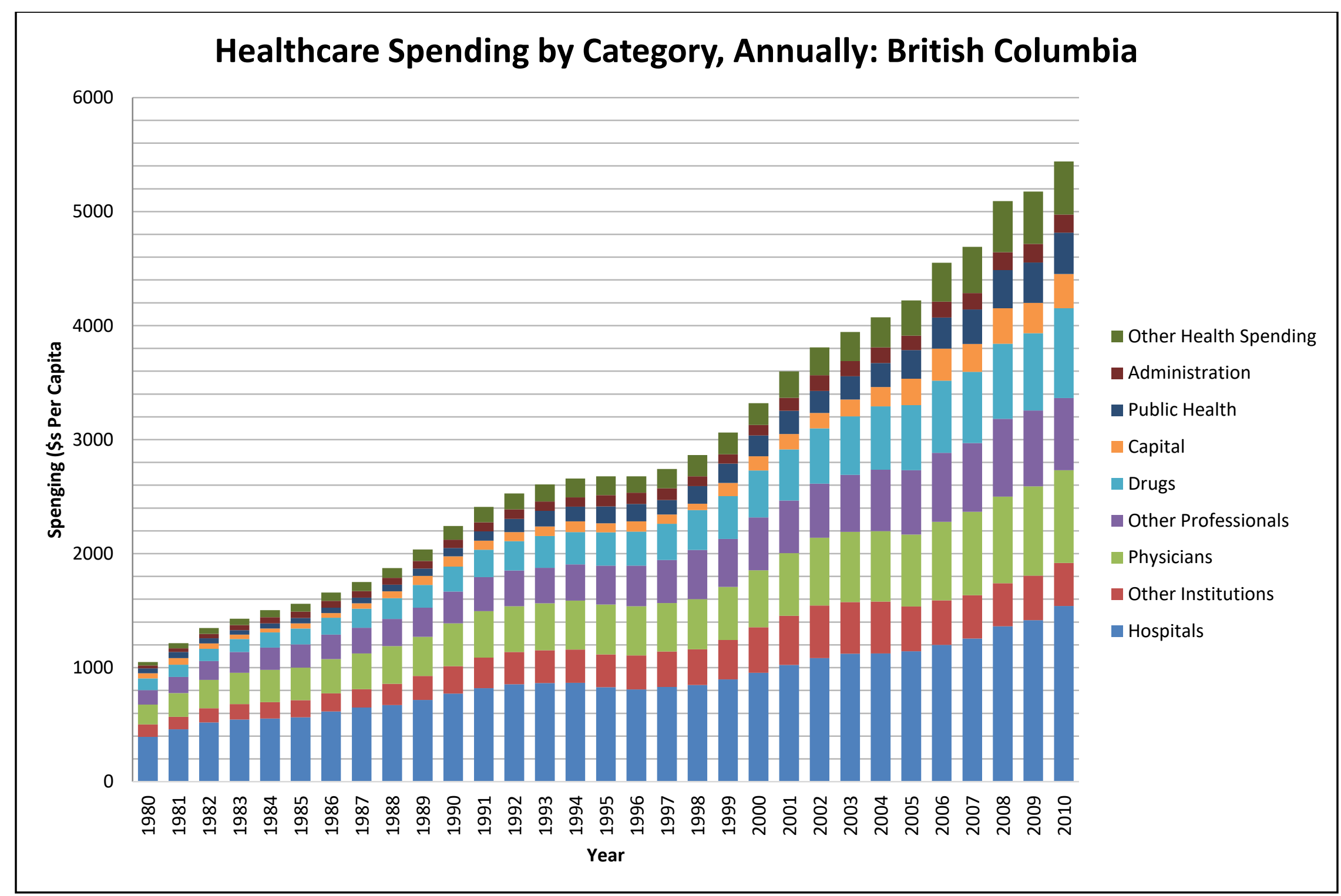

Figure 10: Healthcare Spending by Category - British Columbia 


\begin{tabular}{|c|c|c|c|c|c|c|c|c|c|}
\hline \multicolumn{2}{|c|}{ Hospitals } & \multicolumn{2}{|c|}{ Other Institutions } & \multicolumn{2}{|c|}{ Physicians } & \multicolumn{2}{|c|}{ Other Professionals } & \multicolumn{2}{|c|}{ Drugs } \\
\hline Mean & 881.3632 & Mean & 287.6758 & Mean & 460.25 & Mean & 373.8371 & Mean & 344.2155 \\
\hline $\begin{array}{l}\text { Standard } \\
\text { Error }\end{array}$ & 52.26051 & $\begin{array}{l}\text { Standard } \\
\text { Error }\end{array}$ & 20.28305 & $\begin{array}{l}\text { Standard } \\
\text { Error }\end{array}$ & 31.72337 & $\begin{array}{l}\text { Standard } \\
\text { Error }\end{array}$ & 29.77216 & $\begin{array}{l}\text { Standard } \\
\text { Error }\end{array}$ & 36.01021 \\
\hline Median & 847.92 & Median & 292.56 & Median & 428.77 & Median & 341.27 & Median & 290.53 \\
\hline Mode & \#N/A & Mode & $\# N / A$ & Mode & $\# N / A$ & Mode & $\# N / A$ & Mode & $\# N / A$ \\
\hline $\begin{array}{l}\text { Standard } \\
\text { Deviation }\end{array}$ & 290.9742 & $\begin{array}{l}\text { Standard } \\
\text { Deviation }\end{array}$ & 112.9313 & $\begin{array}{l}\text { Standard } \\
\text { Deviation }\end{array}$ & 176.6282 & $\begin{array}{l}\text { Standard } \\
\text { Deviation }\end{array}$ & 165.7644 & $\begin{array}{l}\text { Standard } \\
\text { Deviation }\end{array}$ & 200.4964 \\
\hline $\begin{array}{c}\text { Sample } \\
\text { Variance }\end{array}$ & 84665.98 & $\begin{array}{c}\text { Sample } \\
\text { Variance }\end{array}$ & 12753.47 & $\begin{array}{c}\text { Sample } \\
\text { Variance }\end{array}$ & 31197.54 & $\begin{array}{c}\text { Sample } \\
\text { Variance }\end{array}$ & 27477.83 & $\begin{array}{c}\text { Sample } \\
\text { Variance }\end{array}$ & 40198.8 \\
\hline Kurtosis & -0.37284 & Kurtosis & -1.27041 & Kurtosis & -0.70595 & Kurtosis & -1.03687 & Kurtosis & -0.79993 \\
\hline Skewness & 0.441047 & Skewness & -0.15316 & Skewness & 0.469874 & Skewness & 0.350804 & Skewness & 0.595843 \\
\hline Range & 1147.79 & Range & 350.69 & Range & 640.53 & Range & 557.05 & Range & 684.01 \\
\hline Minimum & 393.33 & Minimum & 109.47 & Minimum & 172.62 & Minimum & 126.52 & Minimum & 103.01 \\
\hline Maximum & 1541.12 & Maximum & 460.16 & Maximum & 813.15 & Maximum & 683.57 & Maximum & 787.02 \\
\hline Sum & 27322.26 & Sum & 8917.95 & Sum & 14267.75 & Sum & 11588.95 & Sum & 10670.68 \\
\hline Count & 31 & Count & 31 & Count & 31 & Count & 31 & Count & 31 \\
\hline
\end{tabular}




\begin{tabular}{|c|c|c|c|c|c|c|c|}
\hline \multicolumn{2}{|c|}{ Capital } & \multicolumn{2}{|c|}{ Public Health } & \multicolumn{2}{|c|}{ Administration } & \multicolumn{2}{|c|}{ Other Health Spending } \\
\hline Mean & 119.4345 & Mean & 149.7071 & Mean & 92.37613 & Mean & 188.1877 \\
\hline Standard Error & 15.12742 & Standard Error & 17.88016 & Standard Error & 7.132178 & Standard Error & 22.90958 \\
\hline Median & 84.45 & Median & 136.67 & Median & 83.16 & Median & 163.8 \\
\hline Mode & $\# N / A$ & Mode & $\# N / A$ & Mode & $\# N / A$ & Mode & $\# N / A$ \\
\hline $\begin{array}{l}\text { Standard } \\
\text { Deviation }\end{array}$ & 84.22593 & $\begin{array}{l}\text { Standard } \\
\text { Deviation }\end{array}$ & 99.55254 & $\begin{array}{l}\text { Standard } \\
\text { Deviation }\end{array}$ & 39.71029 & $\begin{array}{l}\text { Standard } \\
\text { Deviation }\end{array}$ & 127.5551 \\
\hline $\begin{array}{c}\text { Sample } \\
\text { Variance }\end{array}$ & 7094.007 & $\begin{array}{c}\text { Sample } \\
\text { Variance }\end{array}$ & 9910.708 & $\begin{array}{c}\text { Sample } \\
\text { Variance }\end{array}$ & 1576.907 & $\begin{array}{c}\text { Sample } \\
\text { Variance }\end{array}$ & 16270.31 \\
\hline Kurtosis & 0.147835 & Kurtosis & -0.41978 & Kurtosis & -1.00152 & Kurtosis & 0.00087 \\
\hline Skewness & 1.178926 & Skewness & 0.734127 & Skewness & 0.258654 & Skewness & 0.936512 \\
\hline Range & 274.31 & Range & 323.17 & Range & 137.38 & Range & 433.64 \\
\hline Minimum & 36.1 & Minimum & 40.54 & Minimum & 24.92 & Minimum & 30.18 \\
\hline Maximum & 310.41 & Maximum & 363.71 & Maximum & 162.3 & Maximum & 463.82 \\
\hline Sum & 3702.47 & Sum & 4640.92 & Sum & 2863.66 & Sum & 5833.82 \\
\hline Count & 31 & Count & 31 & Count & 31 & Count & 31 \\
\hline
\end{tabular}




\section{Appendix B - Summary Statistics: Health Outcomes}

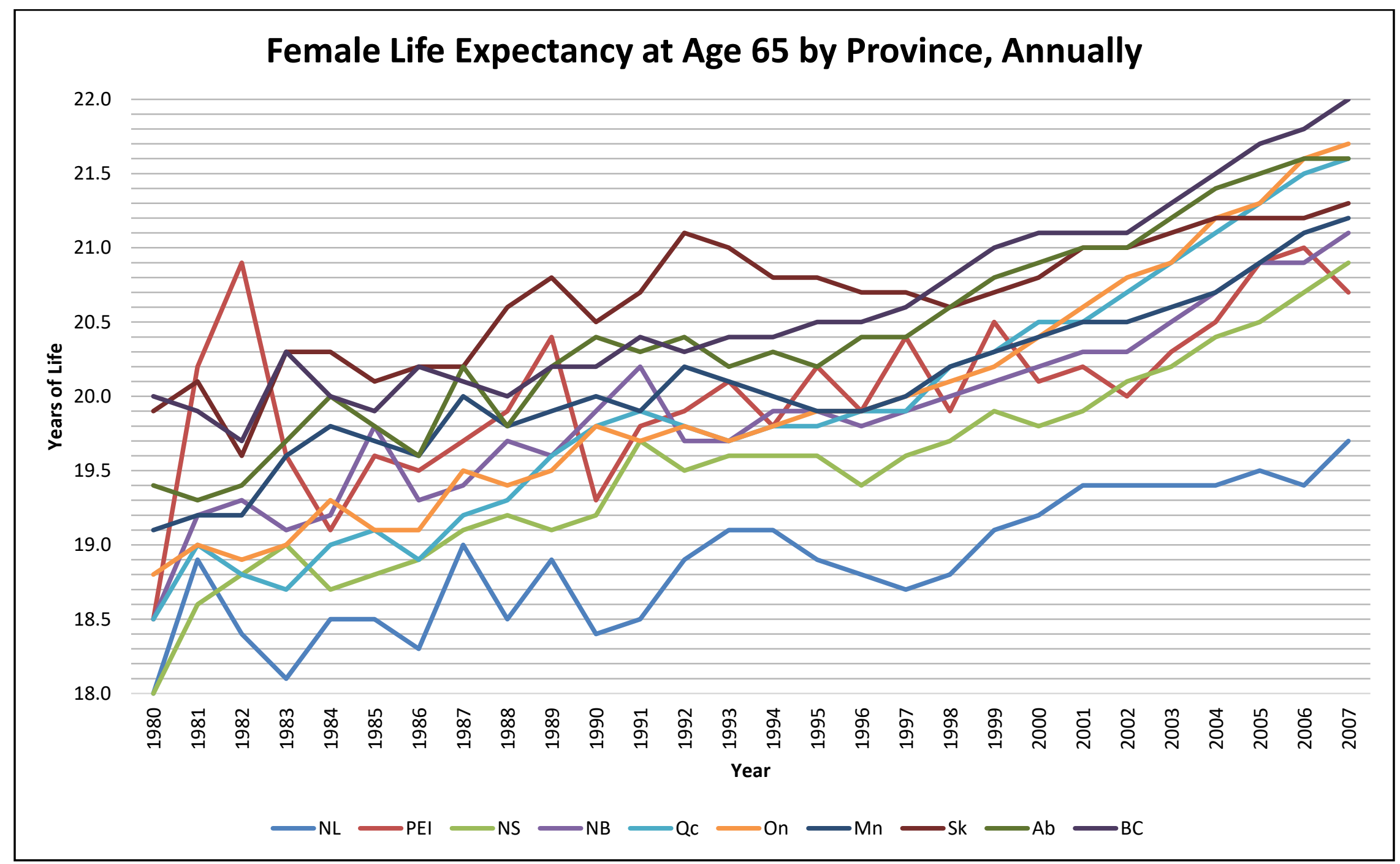

Figure 1: Female Life Expectancy at Age 65 by Province, Annually 


\begin{tabular}{|c|c|c|c|c|c|c|c|c|c|}
\hline \multicolumn{2}{|c|}{$\begin{array}{c}\text { Newfoundland \& } \\
\text { Labrador }\end{array}$} & \multicolumn{2}{|c|}{ Prince Edward Island } & \multicolumn{2}{|c|}{ Nova Scotia } & \multicolumn{2}{|c|}{ New Brunswick } & \multicolumn{2}{|c|}{ Quebec } \\
\hline Mean & 18.89 & Mean & 20.03 & Mean & 19.52 & Mean & 19.90 & Mean & 19.90 \\
\hline $\begin{array}{c}\text { Standard } \\
\text { Error }\end{array}$ & 0.09 & $\begin{array}{c}\text { Standard } \\
\text { Error }\end{array}$ & 0.11 & $\begin{array}{c}\text { Standard } \\
\text { Error }\end{array}$ & 0.13 & $\begin{array}{c}\text { Standard } \\
\text { Error }\end{array}$ & 0.11 & $\begin{array}{c}\text { Standard } \\
\text { Error }\end{array}$ & 0.16 \\
\hline Median & 18.90 & Median & 20.05 & Median & 19.60 & Median & 19.90 & Median & 19.80 \\
\hline Mode & 19.40 & Mode & 19.90 & Mode & 19.60 & Mode & 19.90 & Mode & 19.80 \\
\hline $\begin{array}{l}\text { Standard } \\
\text { Deviation }\end{array}$ & 0.45 & $\begin{array}{l}\text { Standard } \\
\text { Deviation }\end{array}$ & 0.56 & $\begin{array}{l}\text { Standard } \\
\text { Deviation }\end{array}$ & 0.68 & $\begin{array}{l}\text { Standard } \\
\text { Deviation }\end{array}$ & 0.60 & $\begin{array}{l}\text { Standard } \\
\text { Deviation }\end{array}$ & 0.87 \\
\hline $\begin{array}{c}\text { Sample } \\
\text { Variance }\end{array}$ & 0.20 & $\begin{array}{c}\text { Sample } \\
\text { Variance }\end{array}$ & 0.31 & $\begin{array}{c}\text { Sample } \\
\text { Variance }\end{array}$ & 0.46 & $\begin{array}{c}\text { Sample } \\
\text { Variance }\end{array}$ & 0.36 & $\begin{array}{c}\text { Sample } \\
\text { Variance }\end{array}$ & 0.75 \\
\hline Kurtosis & -0.82 & Kurtosis & 0.91 & Kurtosis & -0.10 & Kurtosis & 0.08 & Kurtosis & -0.68 \\
\hline Skewness & -0.15 & Skewness & -0.53 & Skewness & 0.06 & Skewness & 0.04 & Skewness & 0.36 \\
\hline Range & 1.70 & Range & 2.50 & Range & 2.90 & Range & 2.60 & Range & 3.10 \\
\hline Minimum & 18.00 & Minimum & 18.50 & Minimum & 18.00 & Minimum & 18.50 & Minimum & 18.50 \\
\hline Maximum & 19.70 & Maximum & 21.00 & Maximum & 20.90 & Maximum & 21.10 & Maximum & 21.60 \\
\hline Sum & 528.80 & Sum & 560.90 & Sum & 546.50 & Sum & 557.10 & Sum & 557.30 \\
\hline Count & 28 & Count & 28 & Count & 28 & Count & 28 & Count & 28 \\
\hline
\end{tabular}




\begin{tabular}{|c|c|c|c|c|c|c|c|c|c|}
\hline \multicolumn{2}{|c|}{ Ontario } & \multicolumn{2}{|c|}{ Manitoba } & \multicolumn{2}{|c|}{ Saskatchewan } & \multicolumn{2}{|c|}{ Alberta } & \multicolumn{2}{|c|}{ British Columbia } \\
\hline Mean & 19.96 & Mean & 20.08 & Mean & 20.66 & Mean & 20.41 & Mean & 20.61 \\
\hline $\begin{array}{c}\text { Standard } \\
\text { Error }\end{array}$ & 0.16 & $\begin{array}{c}\text { Standard } \\
\text { Error }\end{array}$ & 0.10 & $\begin{array}{c}\text { Standard } \\
\text { Error }\end{array}$ & 0.08 & $\begin{array}{c}\text { Standard } \\
\text { Error }\end{array}$ & 0.13 & $\begin{array}{c}\text { Standard } \\
\text { Error }\end{array}$ & 0.12 \\
\hline Median & 19.80 & Median & 20.00 & Median & 20.70 & Median & 20.35 & Median & 20.40 \\
\hline Mode & 19.80 & Mode & 20.00 & Mode & 20.80 & Mode & 20.20 & Mode & 20.00 \\
\hline $\begin{array}{l}\text { Standard } \\
\text { Deviation }\end{array}$ & 0.83 & $\begin{array}{l}\text { Standard } \\
\text { Deviation }\end{array}$ & 0.53 & $\begin{array}{l}\text { Standard } \\
\text { Deviation }\end{array}$ & 0.44 & $\begin{array}{l}\text { Standard } \\
\text { Deviation }\end{array}$ & 0.67 & $\begin{array}{l}\text { Standard } \\
\text { Deviation }\end{array}$ & 0.63 \\
\hline $\begin{array}{c}\text { Sample } \\
\text { Variance }\end{array}$ & 0.69 & $\begin{array}{c}\text { Sample } \\
\text { Variance }\end{array}$ & 0.28 & $\begin{array}{c}\text { Sample } \\
\text { Variance }\end{array}$ & 0.19 & $\begin{array}{c}\text { Sample } \\
\text { Variance }\end{array}$ & 0.46 & $\begin{array}{c}\text { Sample } \\
\text { Variance }\end{array}$ & 0.40 \\
\hline Kurtosis & -0.45 & Kurtosis & -0.04 & Kurtosis & -0.23 & Kurtosis & -0.76 & Kurtosis & -0.45 \\
\hline Skewness & 0.64 & Skewness & 0.24 & Skewness & -0.60 & Skewness & 0.22 & Skewness & 0.73 \\
\hline Range & 2.90 & Range & 2.10 & Range & 1.70 & Range & 2.30 & Range & 2.30 \\
\hline Minimum & 18.80 & Minimum & 19.10 & Minimum & 19.60 & Minimum & 19.30 & Minimum & 19.70 \\
\hline Maximum & 21.70 & Maximum & 21.20 & Maximum & 21.30 & Maximum & 21.60 & Maximum & 22.00 \\
\hline Sum & 559.00 & Sum & 562.30 & Sum & 578.50 & Sum & 571.60 & Sum & 577.00 \\
\hline Count & 28 & Count & 28 & Count & 28 & Count & 28 & Count & 28 \\
\hline
\end{tabular}




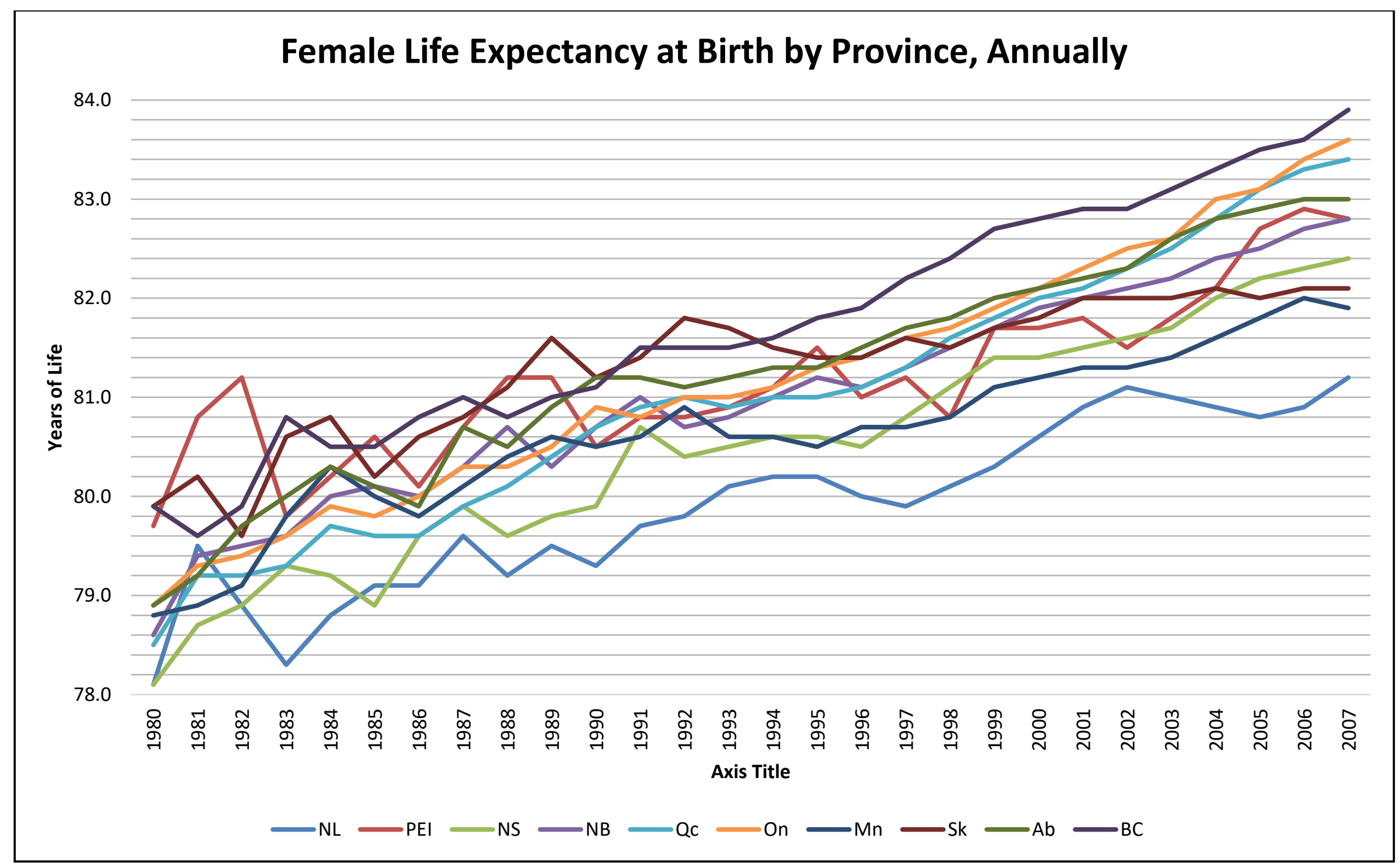

Figure 2: Female Life Expectancy at Birth by Province, Annually 


\begin{tabular}{|c|c|c|c|c|c|c|c|c|c|}
\hline \multicolumn{2}{|c|}{$\begin{array}{c}\text { Newfoundland \& } \\
\text { Labrador }\end{array}$} & \multicolumn{2}{|c|}{ Prince Edward Island } & \multicolumn{2}{|c|}{ Nova Scotia } & \multicolumn{2}{|c|}{ New Brunswick } & \multicolumn{2}{|c|}{ Quebec } \\
\hline Mean & 79.90 & Mean & 81.18 & Mean & 80.49 & Mean & 81.00 & Mean & 81.01 \\
\hline $\begin{array}{c}\text { Standard } \\
\text { Error }\end{array}$ & 0.16 & $\begin{array}{c}\text { Standard } \\
\text { Error }\end{array}$ & 0.16 & $\begin{array}{c}\text { Standard } \\
\text { Error }\end{array}$ & 0.22 & $\begin{array}{c}\text { Standard } \\
\text { Error }\end{array}$ & 0.21 & $\begin{array}{c}\text { Standard } \\
\text { Error }\end{array}$ & 0.26 \\
\hline Median & 79.95 & Median & 81.15 & Median & 80.55 & Median & 81.00 & Median & 81.00 \\
\hline Mode & 80.90 & Mode & 80.80 & Mode & 78.90 & Mode & 80.70 & Mode & 81.00 \\
\hline $\begin{array}{l}\text { Standard } \\
\text { Deviation }\end{array}$ & 0.85 & $\begin{array}{l}\text { Standard } \\
\text { Deviation }\end{array}$ & 0.82 & $\begin{array}{l}\text { Standard } \\
\text { Deviation }\end{array}$ & 1.18 & $\begin{array}{l}\text { Standard } \\
\text { Deviation }\end{array}$ & 1.09 & $\begin{array}{l}\text { Standard } \\
\text { Deviation }\end{array}$ & 1.36 \\
\hline $\begin{array}{c}\text { Sample } \\
\text { Variance }\end{array}$ & 0.73 & $\begin{array}{c}\text { Sample } \\
\text { Variance }\end{array}$ & 0.67 & $\begin{array}{c}\text { Sample } \\
\text { Variance }\end{array}$ & 1.40 & $\begin{array}{c}\text { Sample } \\
\text { Variance }\end{array}$ & 1.20 & $\begin{array}{c}\text { Sample } \\
\text { Variance }\end{array}$ & 1.84 \\
\hline Kurtosis & -0.66 & Kurtosis & 0.02 & Kurtosis & -0.87 & Kurtosis & -0.61 & Kurtosis & -0.86 \\
\hline Skewness & -0.28 & Skewness & 0.39 & Skewness & -0.14 & Skewness & -0.17 & Skewness & 0.10 \\
\hline Range & 3.10 & Range & 3.20 & Range & 4.30 & Range & 4.20 & Range & 4.90 \\
\hline Minimum & 78.10 & Minimum & 79.70 & Minimum & 78.10 & Minimum & 78.60 & Minimum & 78.50 \\
\hline Maximum & 81.20 & Maximum & 82.90 & Maximum & 82.40 & Maximum & 82.80 & Maximum & 83.40 \\
\hline Sum & 2237.10 & Sum & 2273.10 & Sum & 2253.60 & Sum & 2268.10 & Sum & 2268.30 \\
\hline Count & 28 & Count & 28 & Count & 28 & Count & 28 & Count & 28 \\
\hline
\end{tabular}




\begin{tabular}{|c|c|c|c|c|c|c|c|c|c|}
\hline \multicolumn{2}{|c|}{ Ontario } & \multicolumn{2}{|c|}{ Manitoba } & \multicolumn{2}{|c|}{ Saskatchewan } & \multicolumn{2}{|c|}{ Alberta } & \multicolumn{2}{|c|}{ British Columbia } \\
\hline Mean & 81.19 & Mean & 80.62 & Mean & 81.31 & Mean & 81.26 & Mean & 81.75 \\
\hline $\begin{array}{c}\text { Standard } \\
\text { Error }\end{array}$ & 0.25 & $\begin{array}{c}\text { Standard } \\
\text { Error }\end{array}$ & 0.16 & $\begin{array}{c}\text { Standard } \\
\text { Error }\end{array}$ & 0.14 & $\begin{array}{c}\text { Standard } \\
\text { Error }\end{array}$ & 0.22 & $\begin{array}{c}\text { Standard } \\
\text { Error }\end{array}$ & 0.23 \\
\hline Median & 81.05 & Median & 80.60 & Median & 81.50 & Median & 81.25 & Median & 81.55 \\
\hline Mode & 80.30 & Mode & 80.60 & Mode & 82.00 & Mode & 81.20 & Mode & 80.80 \\
\hline $\begin{array}{l}\text { Standard } \\
\text { Deviation }\end{array}$ & 1.31 & $\begin{array}{l}\text { Standard } \\
\text { Deviation }\end{array}$ & 0.84 & $\begin{array}{l}\text { Standard } \\
\text { Deviation }\end{array}$ & 0.71 & $\begin{array}{l}\text { Standard } \\
\text { Deviation }\end{array}$ & 1.15 & $\begin{array}{l}\text { Standard } \\
\text { Deviation }\end{array}$ & 1.21 \\
\hline $\begin{array}{c}\text { Sample } \\
\text { Variance }\end{array}$ & 1.72 & $\begin{array}{c}\text { Sample } \\
\text { Variance }\end{array}$ & 0.70 & $\begin{array}{c}\text { Sample } \\
\text { Variance }\end{array}$ & 0.51 & $\begin{array}{c}\text { Sample } \\
\text { Variance }\end{array}$ & 1.32 & $\begin{array}{c}\text { Sample } \\
\text { Variance }\end{array}$ & 1.47 \\
\hline Kurtosis & -0.88 & Kurtosis & 0.07 & Kurtosis & -0.09 & Kurtosis & -0.68 & Kurtosis & -1.00 \\
\hline Skewness & 0.15 & Skewness & -0.50 & Skewness & -0.91 & Skewness & -0.25 & Skewness & 0.07 \\
\hline Range & 4.70 & Range & 3.20 & Range & 2.50 & Range & 4.10 & Range & 4.30 \\
\hline Minimum & 78.90 & Minimum & 78.80 & Minimum & 79.60 & Minimum & 78.90 & Minimum & 79.60 \\
\hline Maximum & 83.60 & Maximum & 82.00 & Maximum & 82.10 & Maximum & 83.00 & Maximum & 83.90 \\
\hline Sum & 2273.30 & Sum & 2257.30 & Sum & 2276.70 & Sum & 2275.40 & Sum & 2289.00 \\
\hline Count & 28 & Count & 28 & Count & 28 & Count & 28 & Count & 28 \\
\hline
\end{tabular}




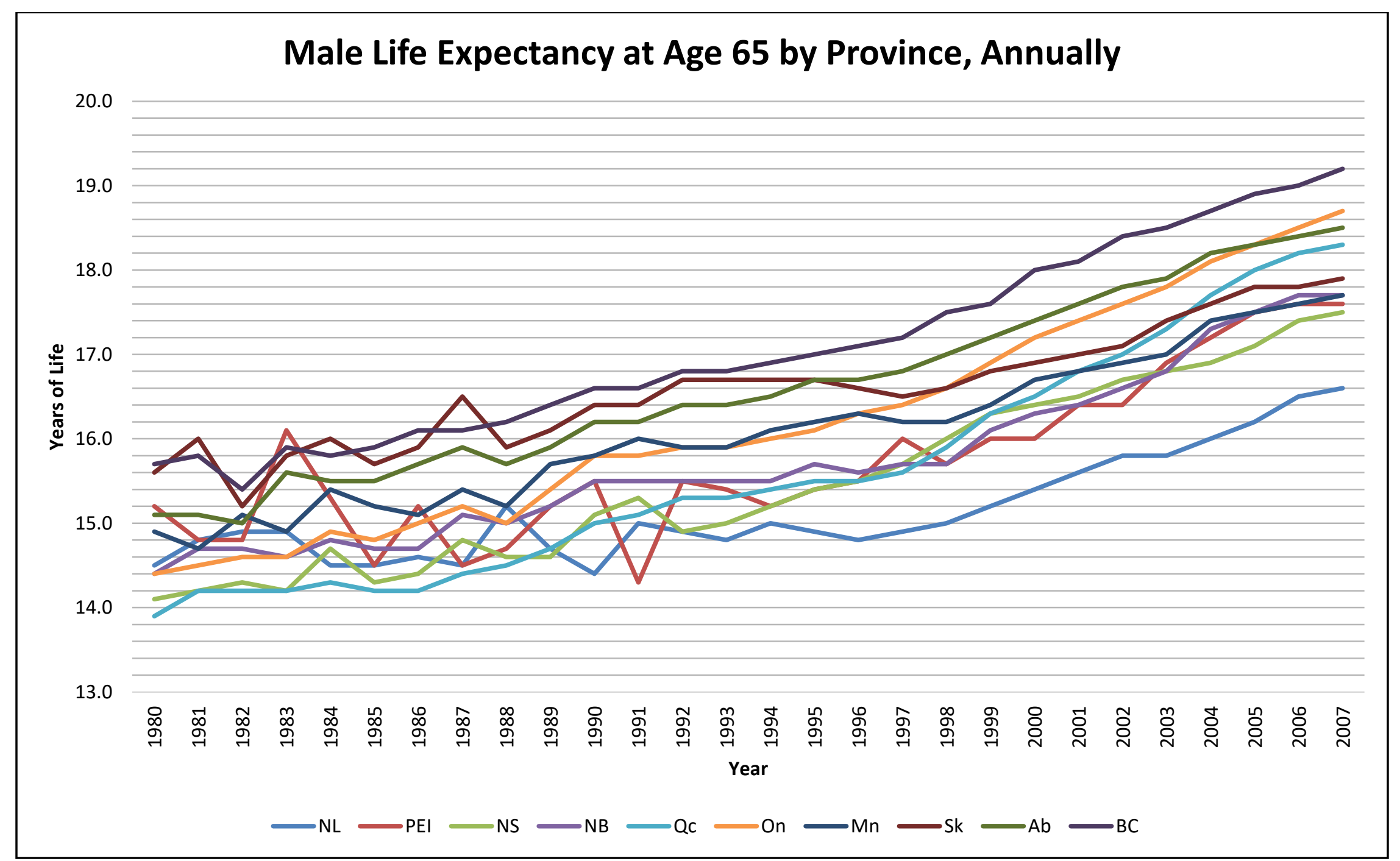

Figure 3: Male Life Expectancy at Age 65 by Province, Annually 


\begin{tabular}{|c|c|c|c|c|c|c|c|c|c|}
\hline \multicolumn{2}{|c|}{$\begin{array}{c}\text { Newfoundland \& } \\
\text { Labrador }\end{array}$} & \multicolumn{2}{|c|}{ Prince Edward Island } & \multicolumn{2}{|c|}{ Nova Scotia } & \multicolumn{2}{|c|}{ New Brunswick } & \multicolumn{2}{|c|}{ Quebec } \\
\hline Mean & 15.14 & Mean & 15.73 & Mean & 15.50 & Mean & 15.73 & Mean & 15.63 \\
\hline $\begin{array}{c}\text { Standard } \\
\text { Error }\end{array}$ & 0.12 & $\begin{array}{l}\text { Standard } \\
\text { Error }\end{array}$ & 0.18 & $\begin{array}{c}\text { Standard } \\
\text { Error }\end{array}$ & 0.20 & $\begin{array}{c}\text { Standard } \\
\text { Error }\end{array}$ & 0.18 & $\begin{array}{c}\text { Standard } \\
\text { Error }\end{array}$ & 0.26 \\
\hline Median & 14.90 & Median & 15.50 & Median & 15.25 & Median & 15.50 & Median & 15.35 \\
\hline Mode & 14.90 & Mode & 15.20 & Mode & 14.20 & Mode & 15.50 & Mode & 14.20 \\
\hline $\begin{array}{l}\text { Standard } \\
\text { Deviation }\end{array}$ & 0.62 & $\begin{array}{l}\text { Standard } \\
\text { Deviation }\end{array}$ & 0.95 & $\begin{array}{l}\text { Standard } \\
\text { Deviation }\end{array}$ & 1.07 & $\begin{array}{l}\text { Standard } \\
\text { Deviation }\end{array}$ & 0.98 & $\begin{array}{l}\text { Standard } \\
\text { Deviation }\end{array}$ & 1.37 \\
\hline $\begin{array}{c}\text { Sample } \\
\text { Variance }\end{array}$ & 0.38 & $\begin{array}{c}\text { Sample } \\
\text { Variance }\end{array}$ & 0.91 & $\begin{array}{c}\text { Sample } \\
\text { Variance }\end{array}$ & 1.15 & $\begin{array}{c}\text { Sample } \\
\text { Variance }\end{array}$ & 0.96 & $\begin{array}{c}\text { Sample } \\
\text { Variance }\end{array}$ & 1.87 \\
\hline Kurtosis & 0.20 & Kurtosis & -0.37 & Kurtosis & -1.13 & Kurtosis & -0.40 & Kurtosis & -0.77 \\
\hline Skewness & 1.05 & Skewness & 0.65 & Skewness & 0.44 & Skewness & 0.73 & Skewness & 0.65 \\
\hline Range & 2.20 & Range & 3.30 & Range & 3.40 & Range & 3.30 & Range & 4.40 \\
\hline Minimum & 14.40 & Minimum & 14.30 & Minimum & 14.10 & Minimum & 14.40 & Minimum & 13.90 \\
\hline Maximum & 16.60 & Maximum & 17.60 & Maximum & 17.50 & Maximum & 17.70 & Maximum & 18.30 \\
\hline Sum & 423.90 & Sum & 440.40 & Sum & 433.90 & Sum & 440.50 & Sum & 437.50 \\
\hline Count & 28 & Count & 28 & Count & 28 & Count & 28 & Count & 28 \\
\hline
\end{tabular}




\begin{tabular}{|c|c|c|c|c|c|c|c|c|c|}
\hline \multicolumn{2}{|c|}{ Ontario } & \multicolumn{2}{|c|}{ Manitoba } & \multicolumn{2}{|c|}{ Saskatchewan } & \multicolumn{2}{|c|}{ Alberta } & \multicolumn{2}{|c|}{ British Columbia } \\
\hline Mean & 16.20 & Mean & 16.08 & Mean & 16.58 & Mean & 16.61 & Mean & 17.08 \\
\hline $\begin{array}{c}\text { Standard } \\
\text { Error }\end{array}$ & 0.25 & $\begin{array}{l}\text { Standard } \\
\text { Error }\end{array}$ & 0.17 & $\begin{array}{c}\text { Standard } \\
\text { Error }\end{array}$ & 0.13 & $\begin{array}{l}\text { Standard } \\
\text { Error }\end{array}$ & 0.20 & $\begin{array}{c}\text { Standard } \\
\text { Error }\end{array}$ & 0.21 \\
\hline Median & 15.95 & Median & 16.05 & Median & 16.60 & Median & 16.45 & Median & 16.85 \\
\hline Mode & 14.60 & Mode & 16.20 & Mode & 16.70 & Mode & 15.10 & Mode & 15.80 \\
\hline $\begin{array}{l}\text { Standard } \\
\text { Deviation }\end{array}$ & 1.32 & $\begin{array}{l}\text { Standard } \\
\text { Deviation }\end{array}$ & 0.88 & $\begin{array}{l}\text { Standard } \\
\text { Deviation }\end{array}$ & 0.70 & $\begin{array}{l}\text { Standard } \\
\text { Deviation }\end{array}$ & 1.07 & $\begin{array}{l}\text { Standard } \\
\text { Deviation }\end{array}$ & 1.14 \\
\hline $\begin{array}{c}\text { Sample } \\
\text { Variance }\end{array}$ & 1.75 & $\begin{array}{c}\text { Sample } \\
\text { Variance }\end{array}$ & 0.77 & $\begin{array}{c}\text { Sample } \\
\text { Variance }\end{array}$ & 0.49 & $\begin{array}{c}\text { Sample } \\
\text { Variance }\end{array}$ & 1.15 & $\begin{array}{c}\text { Sample } \\
\text { Variance }\end{array}$ & 1.29 \\
\hline Kurtosis & -0.98 & Kurtosis & -0.85 & Kurtosis & -0.42 & Kurtosis & -1.04 & Kurtosis & -1.02 \\
\hline Skewness & 0.42 & Skewness & 0.30 & Skewness & 0.22 & Skewness & 0.30 & Skewness & 0.44 \\
\hline Range & 4.30 & Range & 3.00 & Range & 2.70 & Range & 3.50 & Range & 3.80 \\
\hline Minimum & 14.40 & Minimum & 14.70 & Minimum & 15.20 & Minimum & 15.00 & Minimum & 15.40 \\
\hline Maximum & 18.70 & Maximum & 17.70 & Maximum & 17.90 & Maximum & 18.50 & Maximum & 19.20 \\
\hline Sum & 453.70 & Sum & 450.20 & Sum & 464.30 & Sum & 465.20 & Sum & 478.20 \\
\hline Count & 28 & Count & 28 & Count & 28 & Count & 28 & Count & 28 \\
\hline
\end{tabular}




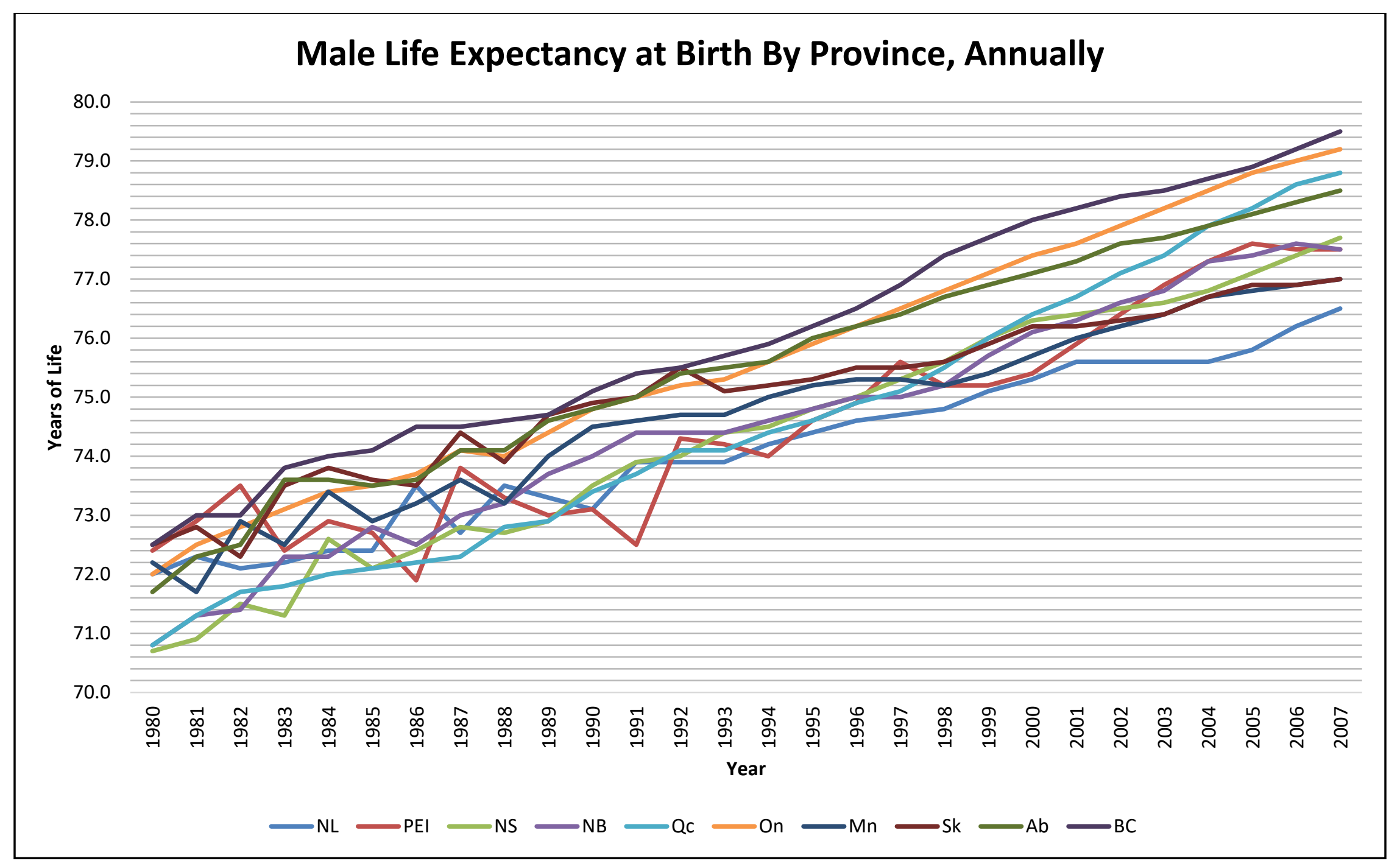

Figure 4: Male Life Expectancy at Birth by Province, Annually 


\begin{tabular}{|c|c|c|c|c|c|c|c|c|c|}
\hline \multicolumn{2}{|c|}{$\begin{array}{c}\text { Newfoundland \& } \\
\text { Labrador }\end{array}$} & \multicolumn{2}{|c|}{ Prince Edward Island } & \multicolumn{2}{|c|}{ Nova Scotia } & \multicolumn{2}{|c|}{ New Brunswick } & \multicolumn{2}{|c|}{ Quebec } \\
\hline Mean & 74.11 & Mean & 74.53 & Mean & 74.35 & Mean & 74.51 & Mean & 74.53 \\
\hline $\begin{array}{c}\text { Standard } \\
\text { Error }\end{array}$ & 0.26 & $\begin{array}{c}\text { Standard } \\
\text { Error }\end{array}$ & 0.34 & $\begin{array}{c}\text { Standard } \\
\text { Error }\end{array}$ & 0.40 & $\begin{array}{c}\text { Standard } \\
\text { Error }\end{array}$ & 0.38 & $\begin{array}{c}\text { Standard } \\
\text { Error }\end{array}$ & 0.46 \\
\hline Median & 74.05 & Median & 74.25 & Median & 74.45 & Median & 74.50 & Median & 74.25 \\
\hline Mode & 75.60 & Mode & 72.40 & Mode & $\# N / A$ & Mode & 74.40 & Mode & 74.10 \\
\hline $\begin{array}{l}\text { Standard } \\
\text { Deviation }\end{array}$ & 1.38 & $\begin{array}{l}\text { Standard } \\
\text { Deviation }\end{array}$ & 1.78 & $\begin{array}{l}\text { Standard } \\
\text { Deviation }\end{array}$ & 2.11 & $\begin{array}{l}\text { Standard } \\
\text { Deviation }\end{array}$ & 2.00 & $\begin{array}{l}\text { Standard } \\
\text { Deviation }\end{array}$ & 2.41 \\
\hline $\begin{array}{c}\text { Sample } \\
\text { Variance }\end{array}$ & 1.90 & $\begin{array}{c}\text { Sample } \\
\text { Variance }\end{array}$ & 3.16 & $\begin{array}{c}\text { Sample } \\
\text { Variance }\end{array}$ & 4.46 & $\begin{array}{c}\text { Sample } \\
\text { Variance }\end{array}$ & 3.99 & $\begin{array}{c}\text { Sample } \\
\text { Variance }\end{array}$ & 5.81 \\
\hline Kurtosis & -1.23 & Kurtosis & -1.06 & Kurtosis & -1.19 & Kurtosis & -0.94 & Kurtosis & -1.11 \\
\hline Skewness & -0.03 & Skewness & 0.40 & Skewness & -0.13 & Skewness & -0.11 & Skewness & 0.29 \\
\hline Range & 4.50 & Range & 5.70 & Range & 7.00 & Range & 6.80 & Range & 8.00 \\
\hline Minimum & 72.00 & Minimum & 71.90 & Minimum & 70.70 & Minimum & 70.80 & Minimum & 70.80 \\
\hline Maximum & 76.50 & Maximum & 77.60 & Maximum & 77.70 & Maximum & 77.60 & Maximum & 78.80 \\
\hline Sum & 2075.20 & Sum & 2086.90 & Sum & 2081.70 & Sum & 2086.40 & Sum & 2086.80 \\
\hline Count & 28 & Count & 28 & Count & 28 & Count & 28 & Count & 28 \\
\hline
\end{tabular}




\begin{tabular}{|c|c|c|c|c|c|c|c|c|c|}
\hline \multicolumn{2}{|c|}{ Ontario } & \multicolumn{2}{|c|}{ Manitoba } & \multicolumn{2}{|c|}{ Saskatchewan } & \multicolumn{2}{|c|}{ Alberta } & \multicolumn{2}{|c|}{ British Columbia } \\
\hline Mean & 75.66 & Mean & 74.69 & Mean & 75.04 & Mean & 75.52 & Mean & 76.09 \\
\hline $\begin{array}{c}\text { Standard } \\
\text { Error }\end{array}$ & 0.41 & $\begin{array}{c}\text { Standard } \\
\text { Error }\end{array}$ & 0.29 & $\begin{array}{c}\text { Standard } \\
\text { Error }\end{array}$ & 0.26 & $\begin{array}{c}\text { Standard } \\
\text { Error }\end{array}$ & 0.37 & $\begin{array}{c}\text { Standard } \\
\text { Error }\end{array}$ & 0.39 \\
\hline Median & 75.45 & Median & 74.85 & Median & 75.25 & Median & 75.55 & Median & 75.80 \\
\hline Mode & $\# N / A$ & Mode & 72.90 & Mode & 75.50 & Mode & 73.60 & Mode & 73.00 \\
\hline $\begin{array}{l}\text { Standard } \\
\text { Deviation }\end{array}$ & 2.15 & $\begin{array}{l}\text { Standard } \\
\text { Deviation }\end{array}$ & 1.52 & $\begin{array}{l}\text { Standard } \\
\text { Deviation }\end{array}$ & 1.37 & $\begin{array}{l}\text { Standard } \\
\text { Deviation }\end{array}$ & 1.96 & $\begin{array}{l}\text { Standard } \\
\text { Deviation }\end{array}$ & 2.08 \\
\hline $\begin{array}{c}\text { Sample } \\
\text { Variance }\end{array}$ & 4.60 & $\begin{array}{c}\text { Sample } \\
\text { Variance }\end{array}$ & 2.32 & $\begin{array}{c}\text { Sample } \\
\text { Variance }\end{array}$ & 1.87 & $\begin{array}{c}\text { Sample } \\
\text { Variance }\end{array}$ & 3.83 & $\begin{array}{c}\text { Sample } \\
\text { Variance }\end{array}$ & 4.34 \\
\hline Kurtosis & -1.16 & Kurtosis & -0.94 & Kurtosis & -0.74 & Kurtosis & -1.00 & Kurtosis & -1.21 \\
\hline Skewness & 0.08 & Skewness & -0.23 & Skewness & -0.44 & Skewness & -0.22 & Skewness & 0.05 \\
\hline Range & 7.20 & Range & 5.30 & Range & 4.70 & Range & 6.80 & Range & 7.00 \\
\hline Minimum & 72.00 & Minimum & 71.70 & Minimum & 72.30 & Minimum & 71.70 & Minimum & 72.50 \\
\hline Maximum & 79.20 & Maximum & 77.00 & Maximum & 77.00 & Maximum & 78.50 & Maximum & 79.50 \\
\hline Sum & 2118.50 & Sum & 2091.20 & Sum & 2101.10 & Sum & 2114.60 & Sum & 2130.40 \\
\hline Count & 28 & Count & 28 & Count & 28 & Count & 28 & Count & 28 \\
\hline
\end{tabular}




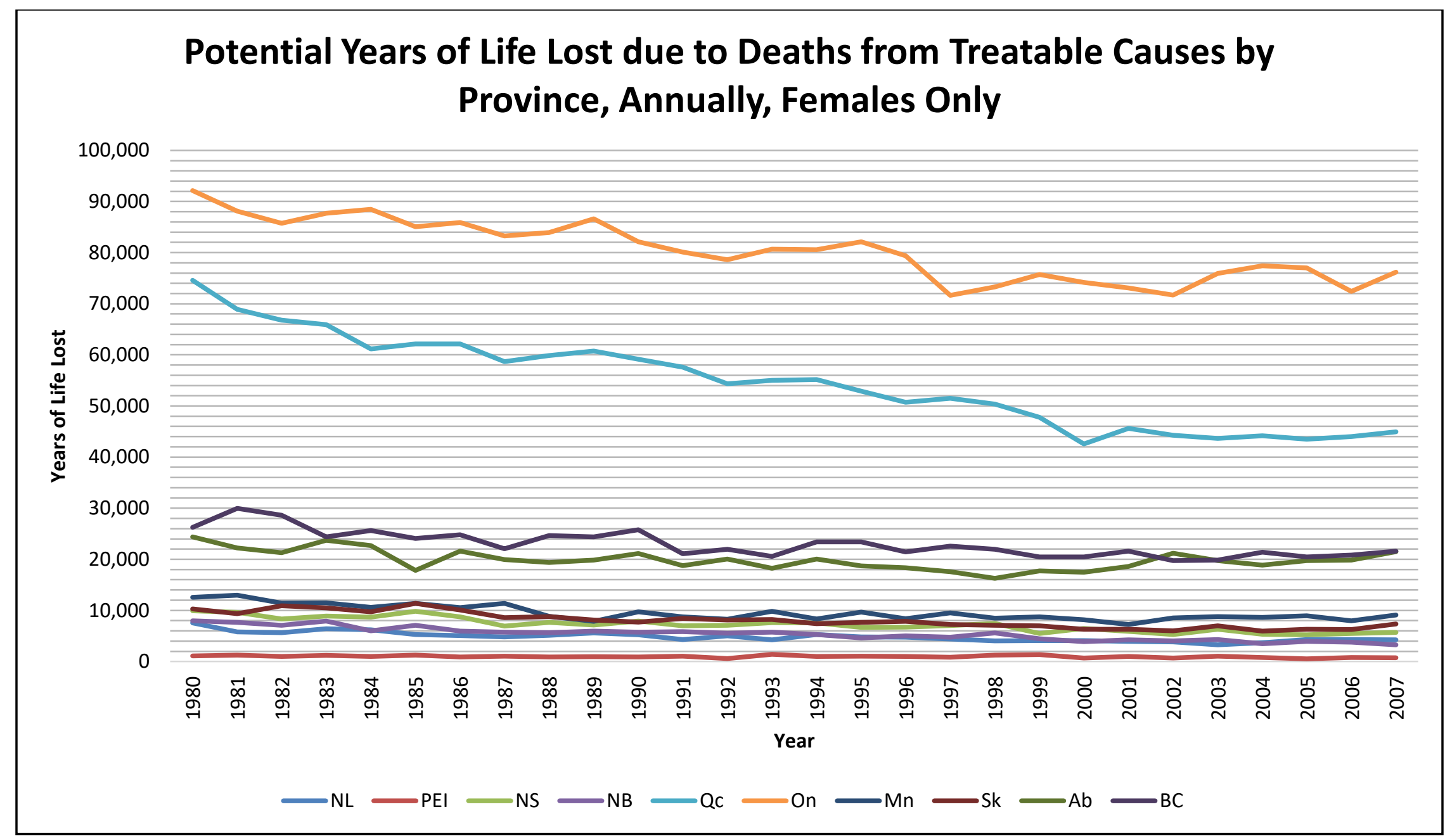

Figure 5: Potential Years of Life Lost due to Deaths from Treatable Causes by Province, Annually, Females Only 


\begin{tabular}{|c|c|c|c|c|c|c|c|c|c|}
\hline \multicolumn{2}{|c|}{$\begin{array}{c}\text { Newfoundland \& } \\
\text { Labrador }\end{array}$} & \multicolumn{2}{|c|}{ Prince Edward Island } & \multicolumn{2}{|c|}{ Nova Scotia } & \multicolumn{2}{|c|}{ New Brunswick } & \multicolumn{2}{|c|}{ Quebec } \\
\hline Mean & 4717.06 & Mean & 952.74 & Mean & 7073.58 & Mean & 5233.52 & Mean & 53834.74 \\
\hline $\begin{array}{c}\text { Standard } \\
\text { Error }\end{array}$ & 173.45 & $\begin{array}{l}\text { Standard } \\
\text { Error }\end{array}$ & 41.45 & $\begin{array}{c}\text { Standard } \\
\text { Error }\end{array}$ & 250.86 & $\begin{array}{c}\text { Standard } \\
\text { Error }\end{array}$ & 239.72 & $\begin{array}{c}\text { Standard } \\
\text { Error }\end{array}$ & 1569.70 \\
\hline Median & 4390 & Median & 983 & Median & 7002 & Median & 5288 & Median & 52889 \\
\hline Mode & $\# N / A$ & Mode & $\# \mathrm{~N} / \mathrm{A}$ & Mode & $\# N / A$ & Mode & $\# N / A$ & Mode & $\# \mathrm{~N} / \mathrm{A}$ \\
\hline $\begin{array}{l}\text { Standard } \\
\text { Deviation }\end{array}$ & 965.73 & $\begin{array}{l}\text { Standard } \\
\text { Deviation }\end{array}$ & 230.77 & $\begin{array}{l}\text { Standard } \\
\text { Deviation }\end{array}$ & 1396.71 & $\begin{array}{l}\text { Standard } \\
\text { Deviation }\end{array}$ & 1334.72 & $\begin{array}{l}\text { Standard } \\
\text { Deviation }\end{array}$ & 8739.72 \\
\hline $\begin{array}{c}\text { Sample } \\
\text { Variance }\end{array}$ & 932636.40 & $\begin{array}{c}\text { Sample } \\
\text { Variance }\end{array}$ & 53256.26 & $\begin{array}{c}\text { Sample } \\
\text { Variance }\end{array}$ & 1950786.92 & $\begin{array}{c}\text { Sample } \\
\text { Variance }\end{array}$ & 1781484.86 & $\begin{array}{c}\text { Sample } \\
\text { Variance }\end{array}$ & 76382624.73 \\
\hline Kurtosis & 1.08 & Kurtosis & -0.52 & Kurtosis & -0.60 & Kurtosis & -0.51 & Kurtosis & -0.62 \\
\hline Skewness & 0.91 & Skewness & 0.04 & Skewness & 0.55 & Skewness & 0.51 & Skewness & 0.52 \\
\hline Range & 4341 & Range & 904 & Range & 4712 & Range & 4698 & Range & 32020 \\
\hline Minimum & 3204 & Minimum & 514 & Minimum & 5241 & Minimum & 3270 & Minimum & 42559 \\
\hline Maximum & 7545 & Maximum & 1418 & Maximum & 9953 & Maximum & 7968 & Maximum & 74579 \\
\hline Sum & 146229 & Sum & 29535 & Sum & 219281 & Sum & 162239 & Sum & 1668877 \\
\hline Count & 31 & Count & 31 & Count & 31 & Count & 31 & Count & 31 \\
\hline
\end{tabular}




\begin{tabular}{|c|c|c|c|c|c|c|c|c|c|}
\hline \multicolumn{2}{|c|}{ Ontario } & \multicolumn{2}{|c|}{ Manitoba } & \multicolumn{2}{|c|}{ Saskatchewan } & \multicolumn{2}{|c|}{ Alberta } & \multicolumn{2}{|c|}{ British Columbia } \\
\hline Mean & 79792.90 & Mean & 9445.61 & Mean & 8006.03 & Mean & 20113.16 & Mean & 22867.45 \\
\hline $\begin{array}{c}\text { Standard } \\
\text { Error }\end{array}$ & 1031.52 & $\begin{array}{c}\text { Standard } \\
\text { Error }\end{array}$ & 260.66 & $\begin{array}{c}\text { Standard } \\
\text { Error }\end{array}$ & 269.25 & $\begin{array}{c}\text { Standard } \\
\text { Error }\end{array}$ & 364.14 & $\begin{array}{c}\text { Standard } \\
\text { Error }\end{array}$ & 448.63 \\
\hline Median & 79363 & Median & 8855 & Median & 7655 & Median & 19843 & Median & 21983 \\
\hline Mode & \#N/A & Mode & $\# N / A$ & Mode & $\# N / A$ & Mode & $\# N / A$ & Mode & \#N/A \\
\hline $\begin{array}{l}\text { Standard } \\
\text { Deviation }\end{array}$ & 5743.25 & $\begin{array}{l}\text { Standard } \\
\text { Deviation }\end{array}$ & 1451.28 & $\begin{array}{l}\text { Standard } \\
\text { Deviation }\end{array}$ & 1499.11 & $\begin{array}{l}\text { Standard } \\
\text { Deviation }\end{array}$ & 2027.44 & $\begin{array}{l}\text { Standard } \\
\text { Deviation }\end{array}$ & 2497.88 \\
\hline $\begin{array}{c}\text { Sample } \\
\text { Variance }\end{array}$ & 32984964.62 & $\begin{array}{c}\text { Sample } \\
\text { Variance }\end{array}$ & 2106216.18 & $\begin{array}{c}\text { Sample } \\
\text { Variance }\end{array}$ & 2247332.70 & $\begin{array}{c}\text { Sample } \\
\text { Variance }\end{array}$ & 4110496.21 & $\begin{array}{c}\text { Sample } \\
\text { Variance }\end{array}$ & 6239390.72 \\
\hline Kurtosis & -0.96 & Kurtosis & -0.03 & Kurtosis & -0.36 & Kurtosis & -0.41 & Kurtosis & 1.19 \\
\hline Skewness & 0.34 & Skewness & 0.89 & Skewness & 0.69 & Skewness & 0.37 & Skewness & 1.18 \\
\hline Range & 20486 & Range & 5722 & Range & 5379 & Range & 8082 & Range & 10237 \\
\hline Minimum & 71664 & Minimum & 7230 & Minimum & 5973 & Minimum & 16290 & Minimum & 19746 \\
\hline Maximum & 92150 & Maximum & 12952 & Maximum & 11352 & Maximum & 24372 & Maximum & 29983 \\
\hline Sum & 2473580 & Sum & 292814 & Sum & 248187 & Sum & 623508 & Sum & 708891 \\
\hline Count & 31 & Count & 31 & Count & 31 & Count & 31 & Count & 31 \\
\hline
\end{tabular}




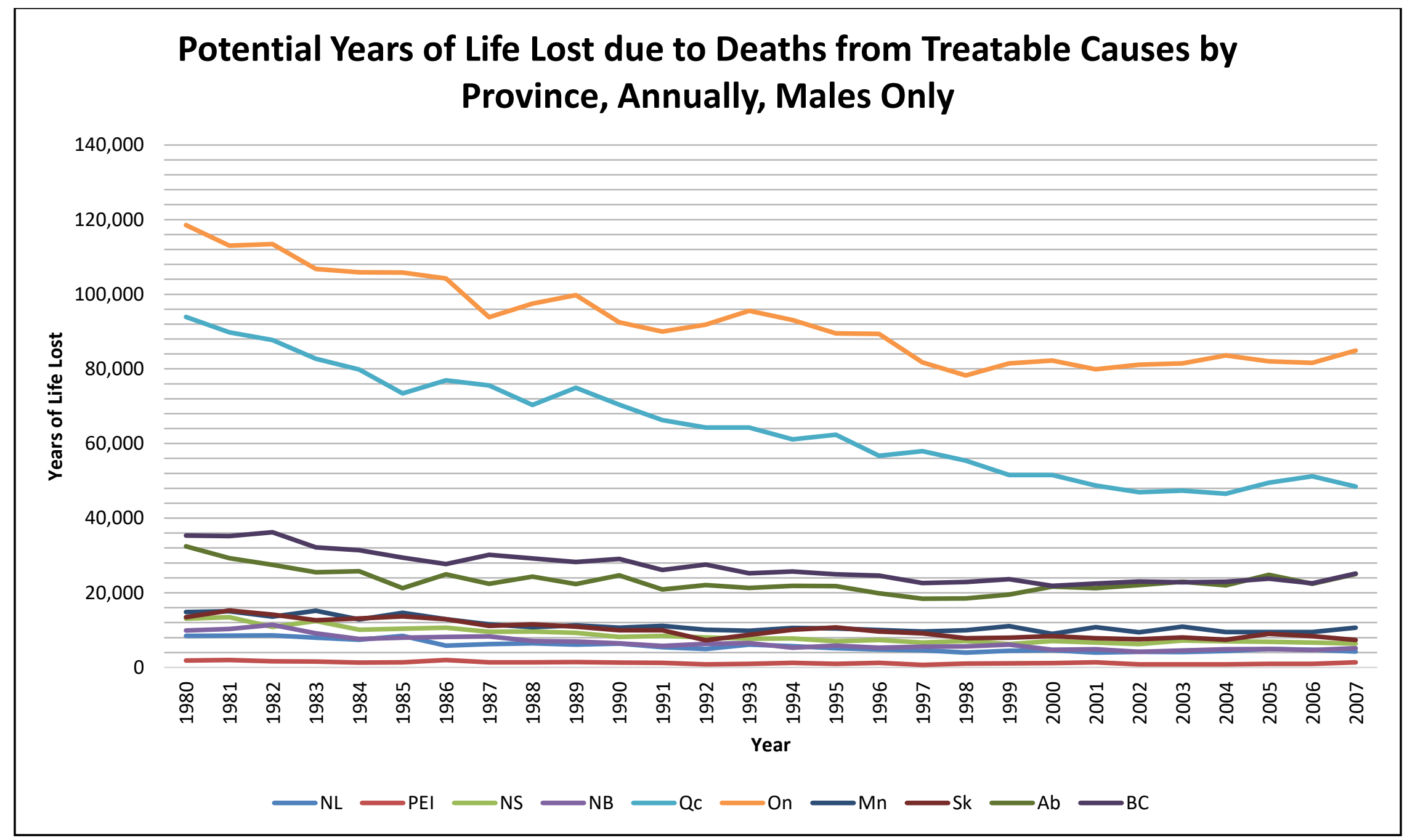

Figure 6: Potential Years of Life Lost due to Deaths from Treatable Causes by Province, Annually, Males Only 


\begin{tabular}{|c|c|c|c|c|c|c|c|c|c|}
\hline \multicolumn{2}{|c|}{$\begin{array}{c}\text { Newfoundland \& } \\
\text { Labrador }\end{array}$} & \multicolumn{2}{|c|}{ Prince Edward Island } & \multicolumn{2}{|c|}{ Nova Scotia } & \multicolumn{2}{|c|}{ New Brunswick } & \multicolumn{2}{|c|}{ Quebec } \\
\hline Mean & 5638.45 & Mean & 1205.45 & Mean & 8305.84 & Mean & 6410.65 & Mean & 62883.35 \\
\hline $\begin{array}{c}\text { Standard } \\
\text { Error }\end{array}$ & 267.04 & $\begin{array}{c}\text { Standard } \\
\text { Error }\end{array}$ & 64.07 & $\begin{array}{c}\text { Standard } \\
\text { Error }\end{array}$ & 376.43 & $\begin{array}{c}\text { Standard } \\
\text { Error }\end{array}$ & 335.81 & $\begin{array}{c}\text { Standard } \\
\text { Error }\end{array}$ & 2597.99 \\
\hline Median & 5073 & Median & 1196 & Median & 7320 & Median & 5782 & Median & 61094 \\
\hline Mode & $\# N / A$ & Mode & $\# N / A$ & Mode & $\# N / A$ & Mode & $\# N / A$ & Mode & $\# \mathrm{~N} / \mathrm{A}$ \\
\hline $\begin{array}{l}\text { Standard } \\
\text { Deviation }\end{array}$ & 1486.80 & $\begin{array}{l}\text { Standard } \\
\text { Deviation }\end{array}$ & 356.70 & $\begin{array}{l}\text { Standard } \\
\text { Deviation }\end{array}$ & 2095.85 & $\begin{array}{l}\text { Standard } \\
\text { Deviation }\end{array}$ & 1869.72 & $\begin{array}{l}\text { Standard } \\
\text { Deviation }\end{array}$ & 14465 \\
\hline $\begin{array}{c}\text { Sample } \\
\text { Variance }\end{array}$ & 2210563.99 & $\begin{array}{c}\text { Sample } \\
\text { Variance }\end{array}$ & 127237.92 & $\begin{array}{c}\text { Sample } \\
\text { Variance }\end{array}$ & 4392580.87 & $\begin{array}{c}\text { Sample } \\
\text { Variance }\end{array}$ & 3495840.30 & $\begin{array}{c}\text { Sample } \\
\text { Variance }\end{array}$ & 209236316.10 \\
\hline Kurtosis & -0.42 & Kurtosis & -0.05 & Kurtosis & 0.38 & Kurtosis & 0.61 & Kurtosis & -0.81 \\
\hline Skewness & 0.90 & Skewness & 0.71 & Skewness & 1.14 & Skewness & 1.15 & Skewness & 0.59 \\
\hline Range & 4601 & Range & 1305 & Range & 7416 & Range & 7210 & Range & 47383 \\
\hline Minimum & 3978 & Minimum & 706 & Minimum & 6085 & Minimum & 4206 & Minimum & 46549 \\
\hline Maximum & 8579 & Maximum & 2011 & Maximum & 13501 & Maximum & 11416 & Maximum & 93932 \\
\hline Sum & 174792 & Sum & 37369 & Sum & 257481 & Sum & 198730 & Sum & 1949384 \\
\hline Count & 31 & Count & 31 & Count & 31 & Count & 31 & Count & 31 \\
\hline
\end{tabular}




\begin{tabular}{|c|c|c|c|c|c|c|c|c|c|}
\hline \multicolumn{2}{|c|}{ Ontario } & \multicolumn{2}{|c|}{ Manitoba } & \multicolumn{2}{|c|}{ Saskatchewan } & \multicolumn{2}{|c|}{ Alberta } & \multicolumn{2}{|c|}{ British Columbia } \\
\hline Mean & 92056 & Mean & 11191.03 & Mean & 9942.65 & Mean & 23339.03 & Mean & 26523.26 \\
\hline $\begin{array}{c}\text { Standard } \\
\text { Error }\end{array}$ & 2031.08 & $\begin{array}{c}\text { Standard } \\
\text { Error }\end{array}$ & 321.61 & $\begin{array}{c}\text { Standard } \\
\text { Error }\end{array}$ & 421.96 & $\begin{array}{c}\text { Standard } \\
\text { Error }\end{array}$ & 550.60 & $\begin{array}{c}\text { Standard } \\
\text { Error }\end{array}$ & 751.67 \\
\hline Median & 89505 & Median & 10680 & Median & 9107 & Median & 22377 & Median & 25157 \\
\hline Mode & $\# N / A$ & Mode & \#N/A & Mode & $\# N / A$ & Mode & $\# N / A$ & Mode & \#N/A \\
\hline $\begin{array}{l}\text { Standard } \\
\text { Deviation }\end{array}$ & 11308.58 & $\begin{array}{l}\text { Standard } \\
\text { Deviation }\end{array}$ & 1790.65 & $\begin{array}{l}\text { Standard } \\
\text { Deviation }\end{array}$ & 2349.37 & $\begin{array}{l}\text { Standard } \\
\text { Deviation }\end{array}$ & 3065.61 & $\begin{array}{l}\text { Standard } \\
\text { Deviation }\end{array}$ & 4185.11 \\
\hline $\begin{array}{c}\text { Sample } \\
\text { Variance }\end{array}$ & 127884042.00 & $\begin{array}{c}\text { Sample } \\
\text { Variance }\end{array}$ & 3206427.97 & $\begin{array}{c}\text { Sample } \\
\text { Variance }\end{array}$ & 5519535.70 & $\begin{array}{c}\text { Sample } \\
\text { Variance }\end{array}$ & 9397969.63 & $\begin{array}{c}\text { Sample } \\
\text { Variance }\end{array}$ & 17515157.00 \\
\hline Kurtosis & -0.35 & Kurtosis & 0.32 & Kurtosis & -0.62 & Kurtosis & 1.44 & Kurtosis & 0.02 \\
\hline Skewness & 0.84 & Skewness & 1.18 & Skewness & 0.76 & Skewness & 0.91 & Skewness & 0.97 \\
\hline Range & 40262 & Range & 6165 & Range & 7993 & Range & 14065 & Range & 14395 \\
\hline Minimum & 78270 & Minimum & 9024 & Minimum & 7294 & Minimum & 18409 & Minimum & 21808 \\
\hline Maximum & 118532 & Maximum & 15189 & Maximum & 15287 & Maximum & 32474 & Maximum & 36203 \\
\hline Sum & 2853736 & Sum & 346922 & Sum & 308222 & Sum & 723510 & Sum & 822221 \\
\hline Count & 31 & Count & 31 & Count & 31 & Count & 31 & Count & 31 \\
\hline
\end{tabular}




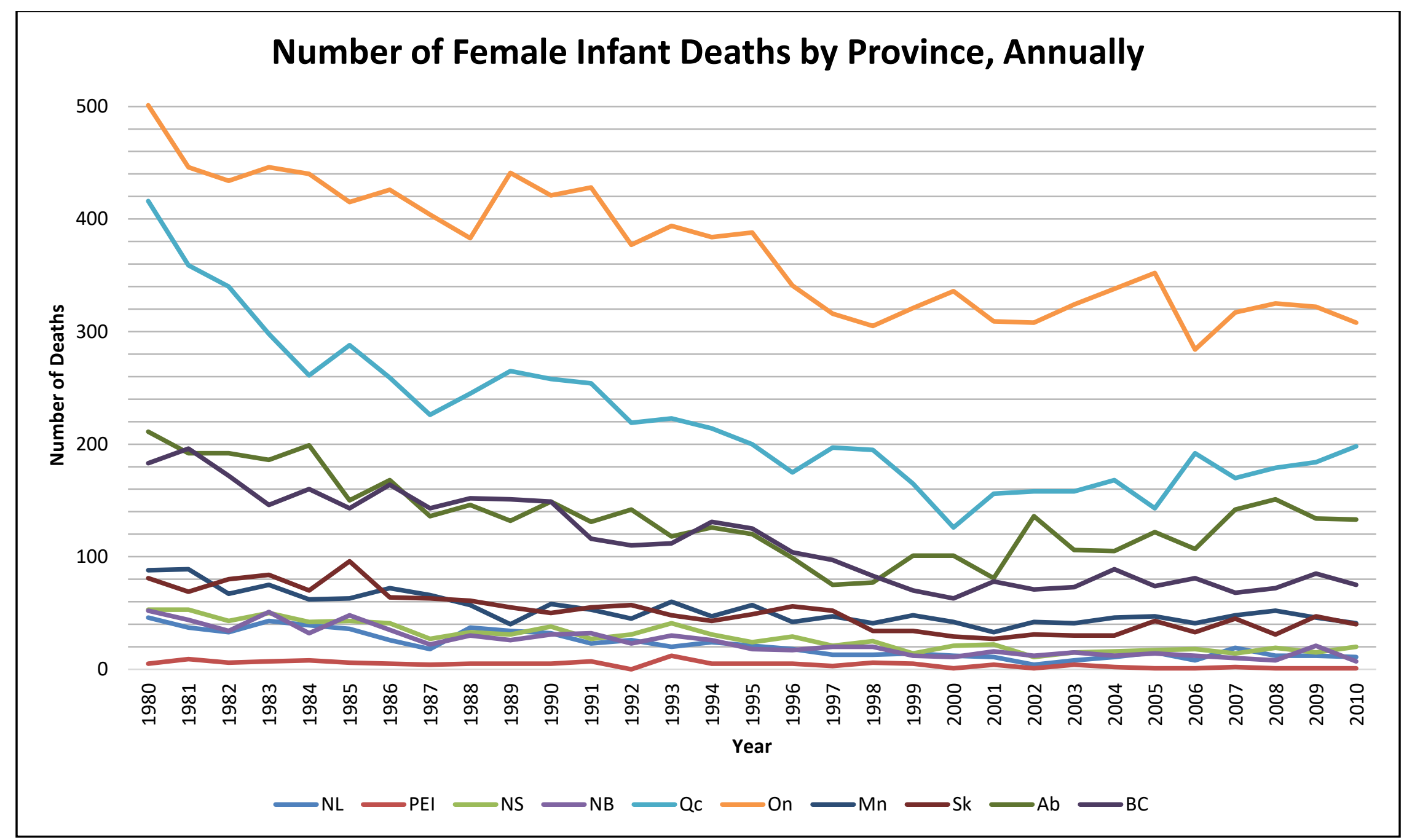

Figure 7: Number of Female Infant Deaths by Province, Annually 


\begin{tabular}{|c|c|c|c|c|c|c|c|c|c|}
\hline \multicolumn{2}{|c|}{$\begin{array}{c}\text { Newfoundland \& } \\
\text { Labrador }\end{array}$} & \multicolumn{2}{|c|}{ Prince Edward Island } & \multicolumn{2}{|c|}{ Nova Scotia } & \multicolumn{2}{|c|}{ New Brunswick } & \multicolumn{2}{|c|}{ Quebec } \\
\hline Mean & 21.81 & Mean & 4.26 & Mean & 28.55 & Mean & 23.90 & Mean & 222.23 \\
\hline $\begin{array}{c}\text { Standard } \\
\text { Error }\end{array}$ & 2.09 & $\begin{array}{c}\text { Standard } \\
\text { Error }\end{array}$ & 0.50 & $\begin{array}{c}\text { Standard } \\
\text { Error }\end{array}$ & 2.21 & $\begin{array}{c}\text { Standard } \\
\text { Error }\end{array}$ & 2.28 & $\begin{array}{c}\text { Standard } \\
\text { Error }\end{array}$ & 12 \\
\hline Median & 19 & Median & 5 & Median & 27 & Median & 21 & Median & 200 \\
\hline Mode & 12 & Mode & 5 & Mode & 31 & Mode & 12 & Mode & 158 \\
\hline $\begin{array}{l}\text { Standard } \\
\text { Deviation }\end{array}$ & 11.62 & $\begin{array}{l}\text { Standard } \\
\text { Deviation }\end{array}$ & 2.77 & $\begin{array}{l}\text { Standard } \\
\text { Deviation }\end{array}$ & 12.32 & $\begin{array}{l}\text { Standard } \\
\text { Deviation }\end{array}$ & 12.69 & $\begin{array}{l}\text { Standard } \\
\text { Deviation }\end{array}$ & 66.79 \\
\hline $\begin{array}{c}\text { Sample } \\
\text { Variance }\end{array}$ & 135.09 & $\begin{array}{c}\text { Sample } \\
\text { Variance }\end{array}$ & 7.66 & $\begin{array}{c}\text { Sample } \\
\text { Variance }\end{array}$ & 151.72 & $\begin{array}{c}\text { Sample } \\
\text { Variance }\end{array}$ & 160.96 & $\begin{array}{c}\text { Sample } \\
\text { Variance }\end{array}$ & 4460.91 \\
\hline Kurtosis & -0.90 & Kurtosis & 0.56 & Kurtosis & -0.79 & Kurtosis & -0.15 & Kurtosis & 1.24 \\
\hline Skewness & 0.53 & Skewness & 0.57 & Skewness & 0.54 & Skewness & 0.79 & Skewness & 1.13 \\
\hline Range & 42 & Range & 12 & Range & 42 & Range & 45 & Range & 290 \\
\hline Minimum & 4 & Minimum & 0 & Minimum & 11 & Minimum & 7 & Minimum & 126 \\
\hline Maximum & 46 & Maximum & 12 & Maximum & 53 & Maximum & 52 & Maximum & 416 \\
\hline Sum & 676 & Sum & 132 & Sum & 885 & Sum & 741 & Sum & 6889 \\
\hline Count & 31 & Count & 31 & Count & 31 & Count & 31 & Count & 31 \\
\hline
\end{tabular}




\begin{tabular}{|c|c|c|c|c|c|c|c|c|c|}
\hline \multicolumn{2}{|c|}{ Ontario } & \multicolumn{2}{|c|}{ Manitoba } & \multicolumn{2}{|c|}{ Saskatchewan } & \multicolumn{2}{|c|}{ Alberta } & \multicolumn{2}{|c|}{ British Columbia } \\
\hline Mean & 372.06 & Mean & 53.42 & Mean & 51.19 & Mean & 134.45 & Mean & 114.0645 \\
\hline $\begin{array}{c}\text { Standard } \\
\text { Error }\end{array}$ & 10.22 & $\begin{array}{c}\text { Standard } \\
\text { Error }\end{array}$ & 2.51 & $\begin{array}{c}\text { Standard } \\
\text { Error }\end{array}$ & 3.28 & $\begin{array}{c}\text { Standard } \\
\text { Error }\end{array}$ & 6.37 & $\begin{array}{c}\text { Standard } \\
\text { Error }\end{array}$ & 7.102315 \\
\hline Median & 377 & Median & 48 & Median & 49 & Median & 133 & Median & 110 \\
\hline Mode & 446 & Mode & 41 & Mode & 55 & Mode & 192 & Mode & 143 \\
\hline $\begin{array}{l}\text { Standard } \\
\text { Deviation }\end{array}$ & 56.91 & $\begin{array}{l}\text { Standard } \\
\text { Deviation }\end{array}$ & 13.95 & $\begin{array}{l}\text { Standard } \\
\text { Deviation }\end{array}$ & 18.26 & $\begin{array}{l}\text { Standard } \\
\text { Deviation }\end{array}$ & 35.48 & $\begin{array}{l}\text { Standard } \\
\text { Deviation }\end{array}$ & 39.54401 \\
\hline $\begin{array}{c}\text { Sample } \\
\text { Variance }\end{array}$ & 3238.66 & $\begin{array}{c}\text { Sample } \\
\text { Variance }\end{array}$ & 194.72 & $\begin{array}{c}\text { Sample } \\
\text { Variance }\end{array}$ & 333.49 & $\begin{array}{c}\text { Sample } \\
\text { Variance }\end{array}$ & 1258.52 & $\begin{array}{c}\text { Sample } \\
\text { Variance }\end{array}$ & 1563.729 \\
\hline Kurtosis & -1 & Kurtosis & 0.77 & Kurtosis & -0.18 & Kurtosis & -0.24 & Kurtosis & -1.12745 \\
\hline Skewness & 0.33 & Skewness & 1.10 & Skewness & 0.66 & Skewness & 0.43 & Skewness & 0.406277 \\
\hline Range & 217 & Range & 56 & Range & 69 & Range & 136 & Range & 133 \\
\hline Minimum & 284 & Minimum & 33 & Minimum & 27 & Minimum & 75 & Minimum & 63 \\
\hline Maximum & 501 & Maximum & 89 & Maximum & 96 & Maximum & 211 & Maximum & 196 \\
\hline Sum & 11534 & Sum & 1656 & Sum & 1587 & Sum & 4168 & Sum & 3536 \\
\hline Count & 31 & Count & 31 & Count & 31 & Count & 31 & Count & 31 \\
\hline
\end{tabular}




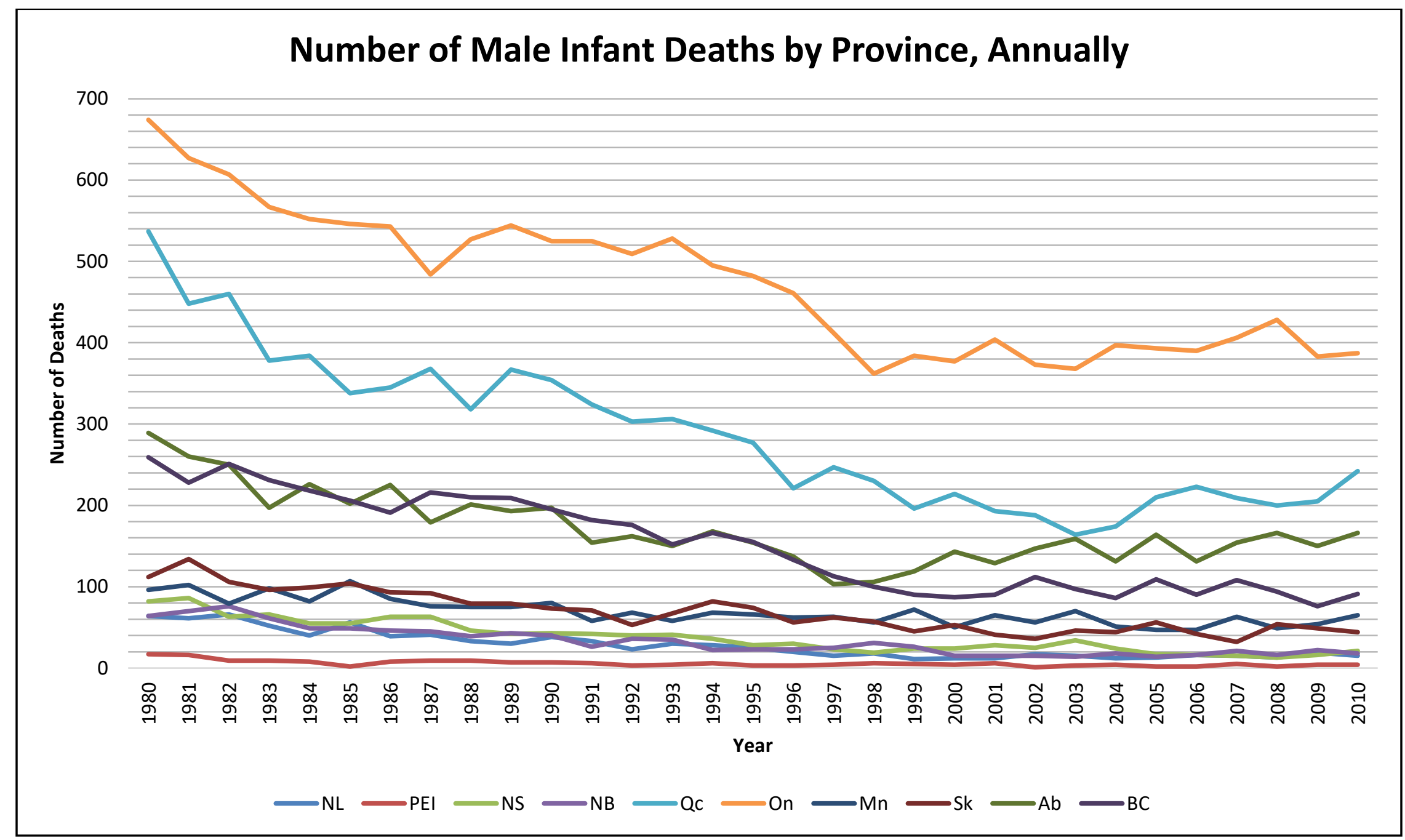

Figure 8: Number of Male Infant Deaths by Province, Annually 


\begin{tabular}{|c|c|c|c|c|c|c|c|c|c|}
\hline \multicolumn{2}{|c|}{$\begin{array}{c}\text { Newfoundland \& } \\
\text { Labrador }\end{array}$} & \multicolumn{2}{|c|}{ Prince Edward Island } & \multicolumn{2}{|c|}{ Nova Scotia } & \multicolumn{2}{|c|}{ New Brunswick } & \multicolumn{2}{|c|}{ Quebec } \\
\hline Mean & 28.45 & Mean & 5.74 & Mean & 38.06 & Mean & 32.68 & Mean & 287.58 \\
\hline $\begin{array}{c}\text { Standard } \\
\text { Error }\end{array}$ & 3.02 & $\begin{array}{c}\text { Standard } \\
\text { Error }\end{array}$ & 0.67 & $\begin{array}{c}\text { Standard } \\
\text { Error }\end{array}$ & 3.61 & $\begin{array}{c}\text { Standard } \\
\text { Error }\end{array}$ & 3.19 & $\begin{array}{c}\text { Standard } \\
\text { Error }\end{array}$ & 16.86 \\
\hline Median & 23 & Median & 5 & Median & 34 & Median & 26 & Median & 277 \\
\hline Mode & 15 & Mode & 4 & Mode & 63 & Mode & 15 & Mode & $\# N / A$ \\
\hline $\begin{array}{l}\text { Standard } \\
\text { Deviation }\end{array}$ & 16.83 & $\begin{array}{l}\text { Standard } \\
\text { Deviation }\end{array}$ & 3.72 & $\begin{array}{l}\text { Standard } \\
\text { Deviation }\end{array}$ & 20.07 & $\begin{array}{l}\text { Standard } \\
\text { Deviation }\end{array}$ & 17.75 & $\begin{array}{l}\text { Standard } \\
\text { Deviation }\end{array}$ & 93.86 \\
\hline $\begin{array}{c}\text { Sample } \\
\text { Variance }\end{array}$ & 283.39 & $\begin{array}{c}\text { Sample } \\
\text { Variance }\end{array}$ & 13.86 & $\begin{array}{c}\text { Sample } \\
\text { Variance }\end{array}$ & 403 & $\begin{array}{c}\text { Sample } \\
\text { Variance }\end{array}$ & 315.23 & $\begin{array}{c}\text { Sample } \\
\text { Variance }\end{array}$ & 8809.78 \\
\hline Kurtosis & -0.14 & Kurtosis & 2.86 & Kurtosis & -0.13 & Kurtosis & 0.01 & Kurtosis & 0.14 \\
\hline Skewness & 0.97 & Skewness & 1.55 & Skewness & 0.82 & Skewness & 0.95 & Skewness & 0.80 \\
\hline Range & 55 & Range & 16 & Range & 73 & Range & 62 & Range & 373 \\
\hline Minimum & 11 & Minimum & 1 & Minimum & 13 & Minimum & 14 & Minimum & 164 \\
\hline Maximum & 66 & Maximum & 17 & Maximum & 86 & Maximum & 76 & Maximum & 537 \\
\hline Sum & 882 & Sum & 178 & Sum & 1180 & Sum & 1013 & Sum & 8915 \\
\hline Count & 31 & Count & 31 & Count & 31 & Count & 31 & Count & 31 \\
\hline
\end{tabular}




\begin{tabular}{|c|c|c|c|c|c|c|c|c|c|}
\hline \multicolumn{2}{|c|}{ Ontario } & \multicolumn{2}{|c|}{ Manitoba } & \multicolumn{2}{|c|}{ Saskatchewan } & \multicolumn{2}{|c|}{ Alberta } & \multicolumn{2}{|c|}{ British Columbia } \\
\hline Mean & 472.90 & Mean & 69.13 & Mean & 68.74 & Mean & 171.35 & Mean & 152.29 \\
\hline $\begin{array}{c}\text { Standard } \\
\text { Error }\end{array}$ & 15.59 & $\begin{array}{c}\text { Standard } \\
\text { Error }\end{array}$ & 2.91 & $\begin{array}{c}\text { Standard } \\
\text { Error }\end{array}$ & 4.62 & $\begin{array}{c}\text { Standard } \\
\text { Error }\end{array}$ & 7.96 & $\begin{array}{c}\text { Standard } \\
\text { Error }\end{array}$ & 10.49 \\
\hline Median & 482 & Median & 66 & Median & 62 & Median & 162 & Median & 152 \\
\hline Mode & 525 & Mode & 75 & Mode & 79. & Mode & 154 & Mode & 90 \\
\hline $\begin{array}{l}\text { Standard } \\
\text { Deviation }\end{array}$ & 86.78 & $\begin{array}{l}\text { Standard } \\
\text { Deviation }\end{array}$ & 16.23 & $\begin{array}{l}\text { Standard } \\
\text { Deviation }\end{array}$ & 25.70 & $\begin{array}{l}\text { Standard } \\
\text { Deviation }\end{array}$ & 44.31 & $\begin{array}{l}\text { Standard } \\
\text { Deviation }\end{array}$ & 58.39 \\
\hline $\begin{array}{c}\text { Sample } \\
\text { Variance }\end{array}$ & 7531.16 & $\begin{array}{c}\text { Sample } \\
\text { Variance }\end{array}$ & 263.38 & $\begin{array}{c}\text { Sample } \\
\text { Variance }\end{array}$ & 660.40 & $\begin{array}{c}\text { Sample } \\
\text { Variance }\end{array}$ & 1963.30 & $\begin{array}{c}\text { Sample } \\
\text { Variance }\end{array}$ & 3408.88 \\
\hline Kurtosis & -0.76 & Kurtosis & -0.04 & Kurtosis & -0.24 & Kurtosis & 0.59 & Kurtosis & -1.44 \\
\hline Skewness & 0.46 & Skewness & 0.73 & Skewness & 0.69 & Skewness & 0.89 & Skewness & 0.28 \\
\hline Range & 312 & Range & 60 & Range & 102 & Range & 186 & Range & 183 \\
\hline Minimum & 362 & Minimum & 47 & Minimum & 32 & Minimum & 103 & Minimum & 76 \\
\hline Maximum & 674 & Maximum & 107 & Maximum & 134 & Maximum & 289 & Maximum & 259 \\
\hline Sum & 14660 & Sum & 2143 & Sum & 2131 & Sum & 5312 & Sum & 4721 \\
\hline Mean & 472.90 & Mean & 69.13 & Mean & 68.74 & Mean & 171.35 & Mean & 152.29 \\
\hline
\end{tabular}




\section{Appendix C - MARS Models from Analyses of Infant Mortality \& Deaths from $\underline{\text { Treatable Causes }}$}

\section{Explanation of Basis Functions}

In order to avoid an overly prolonged discussion of the basis functions within each model, three of the basis functions which resulted from the analysis of PYLL will be used to explain how each should be interpreted. This will aid in the interpretation of the overall models which will be discussed below.

We begin by examining with the simple basis function BF1 from the MARS model analyzing FPYLL. BF1 indicates that from 1980 to 2010, when spending on Drugs was below \$223.76 per person it had no effect in determining FPYLL in the overall model. In BF2 from the FPYLL MARS model we see that, over the same time period, when spending on Drugs was greater than $\$ 223.76$ it had no effect on the final model. BF1 represents the influence of spending on Drugs before the knot point where spending levels reach $\$ 223.76$ per person while $\mathrm{BF} 2$ represents the influence of the same variable after this knot point.

BF7 from the FPYLL MARS model represents a complex basis function as it is composed of the product of two simple basis functions. In examining BF7 we see that when spending on Physicians was less than $\$ 78.22$ per person between 1980 and 2010, it had no effect on determining FPYLL in the final model. We also see that this first simple basis function is multiplied by the previously discussed BF1. Therefore in order for BF7 to have an effect on determining FPYLL in the final model, spending on Physicians must be greater than $\$ 78.22$ per person, and spending on Drugs must be greater than $\$ 233.76$ per person.

These same interpretations can be applied to the simple and complex basis functions contained in both final MARS models examining both PYLLTC (Tables 1 and 2) and Infant Deaths (Tables 3 and 4). 


\begin{tabular}{|c|c|}
\hline \multicolumn{2}{|c|}{ FPYLL } \\
\hline Simple Basis Functions & Complex Basis Functions \\
\hline $\begin{array}{l}\text { BF1 = } \max (0, \text { DRUGS }-223.76) ; \\
\text { BF2 = } \max (0,223.76-\text { DRUGS }) ; \\
\text { BF3 = } \max (0, \text { PHYSICIANS - 439.57); } \\
\text { BF5 = } \max (0, \text { HOSPITALS }-773.94) ; \\
\text { BF8 = } \max (0, \text { PUBLIC_HEALTH }-153.47) ; \\
\text { BF9 = } \max (0,153.47-\text { PUBLIC_HEALTH }) ; \\
\text { BF18 = } \max (0, \text { HOSPITALS - 1506.4) }\end{array}$ & 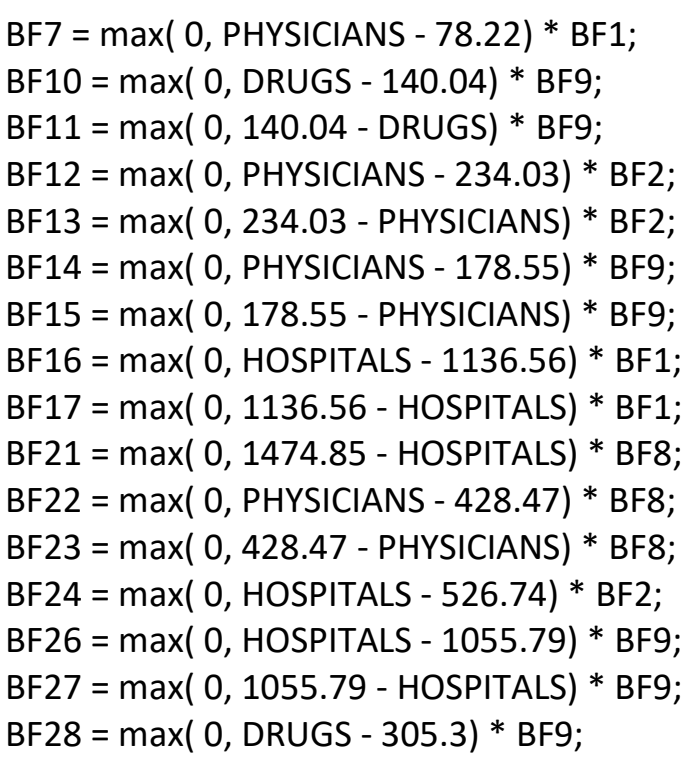 \\
\hline \multicolumn{2}{|c|}{ Final Model } \\
\hline \multicolumn{2}{|c|}{$\begin{aligned} & \mathrm{Y}=-21368.2-188.868 * \mathrm{BF} 1-176.007 * \mathrm{BF} 3+56.1723 * \mathrm{BF} 5 \\
&+0.855825 * \mathrm{BF} 7+238.447 * \mathrm{BF} 8-1.57102 * \mathrm{BF} 10 \\
&+6.72884 * \mathrm{BF} 11-13.9948 * \mathrm{BF} 12-2.95269 * \mathrm{BF} 13 \\
&+ 4.66213 * \mathrm{BF} 14-3.21607 * \mathrm{BF} 15-0.66042 * \mathrm{BF} 16 \\
&+0.71892 * \mathrm{BF} 17+333.072 * \mathrm{BF} 18-1.24937 * \mathrm{BF} 21 \\
&-1.09897 * \mathrm{BF} 22+4.20016 * \mathrm{BF} 23+2.11627 * \mathrm{BF} 24 \\
&+1.68031 * \mathrm{BF} 26+0.966344 * \mathrm{BF} 27-3.36202 * \mathrm{BF} 28\end{aligned}$} \\
\hline
\end{tabular}




\begin{tabular}{|c|c|}
\hline & MPYLL \\
\hline Simple Basis Functions & Complex Basis Functions \\
\hline $\begin{array}{l}\text { BF1 = } \max (0, \text { DRUGS }-223.76) ; \\
\text { BF2 = } \max (0,223.76-\text { DRUGS }) ; \\
\text { BF3 = } \max (0, \text { PHYSICIANS }-439.57) ; \\
\text { BF6 = } \max (0,773.94-\text { HOSPITALS }) ; \\
\text { BF8 = } \max (0, \text { PUBLIC_HEALTH }-138.88) ; \\
\text { BF9 = } \max (0,138.88-\text { PUBLIC_HEALTH }) ; \\
\text { BF18 = } \max (0, \text { HOSPITALS }-1506.4) ; \\
\text { BF19 = } \max (0,1506.4-\text { HOSPITALS }) ;\end{array}$ & 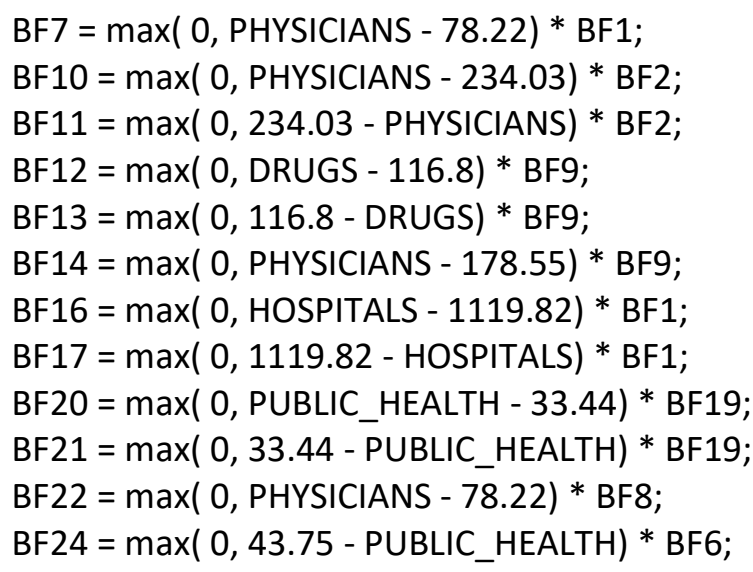 \\
\hline & al Model \\
\hline $\begin{aligned} & \mathrm{Y}=50790.3-322.566 * \mathrm{BF} 1+290.738 * \\
&+1.02461 * \mathrm{BF} 7+569.371 * \mathrm{BF} 8- \\
&-6.75225 * \mathrm{BF} 11-4.19211 * \mathrm{BF} 12 \\
&+6.19353 * \mathrm{BF} 14-0.588008 * \mathrm{BF}- \\
&+323.291 * \mathrm{BF} 18-0.745951 * \mathrm{BF} 2 \\
&-1.05875 * \mathrm{BF} 22+9.96406 * \mathrm{BF} 2\end{aligned}$ & $\begin{array}{l}01 * \mathrm{BF} 3 \\
\mathrm{BF} 10 \\
* \mathrm{BF} 13 \\
94 * \mathrm{BF} 17 \\
5^{*} \mathrm{BF} 21\end{array}$ \\
\hline
\end{tabular}




\begin{tabular}{|c|c|}
\hline & NFID \\
\hline Simple Basis Functions & Complex Basis Functions \\
\hline $\begin{array}{l}\text { BF1 = } \max (0, \text { DRUGS }-223.76) ; \\
\text { BF2 = } \max (0,223.76-\text { DRUGS }) ; \\
\text { BF4 = } \max (0,439.57-\text { PHYSICIANS }) ; \\
\text { BF8 = } \max (0,804.43-\text { HOSPITALS }) ; \\
\text { BF15 = } \max (0, \text { OTHER_PROFESSIONALS - 383.85); } \\
\text { BF16 = } \max (0,383.85-\text { OTHER_PROFESSIONALS); } \\
\text { BF29 = } \max (0,335.5-\text { OTHER_HEALTH_SPENDING); }\end{array}$ & 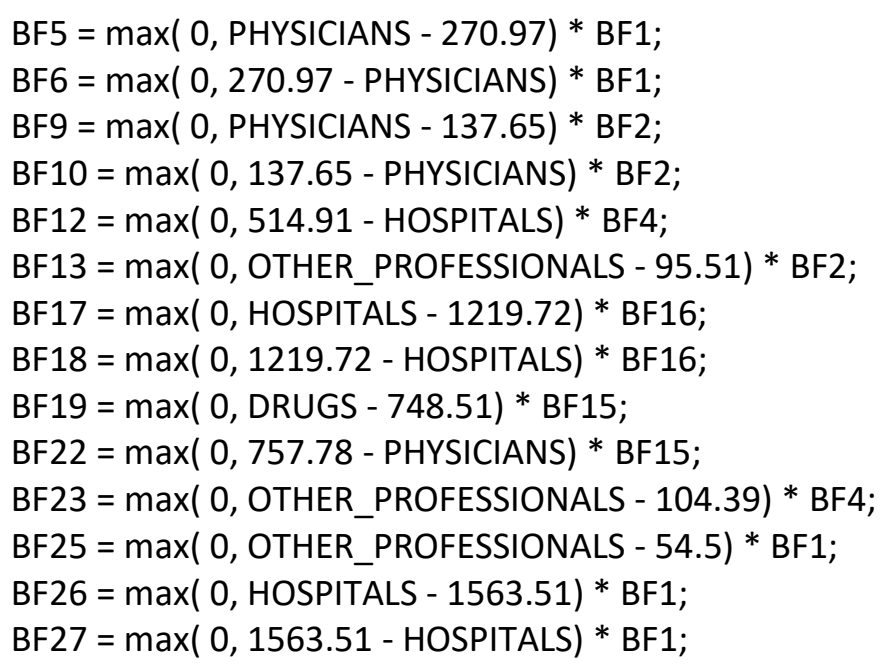 \\
\hline \multicolumn{2}{|c|}{ Final Model } \\
\hline \multicolumn{2}{|c|}{$\begin{aligned} & \mathrm{Y}=-58.1241-2.85776 * \mathrm{BF} 1+2.4002 * \mathrm{BF} 2-3.24257 * \mathrm{BF} 4 \\
&+0.00139846 * \mathrm{BF} 5+0.017306 * \mathrm{BF} 6-0.537652 * \mathrm{BF} 8 \\
&+0.0246415 * \mathrm{BF} 9-0.0532958 * \mathrm{BF} 10+0.00341132 * \mathrm{BF} 12 \\
&-0.0548413 * \mathrm{BF} 13-3.24687 * \mathrm{BF} 15+1.71777 * \mathrm{BF} 16 \\
&+0.0051001 * \mathrm{BF} 17+0.00175204 * \mathrm{BF} 18-0.00678571 * \mathrm{BF} 19 \\
&+0.00601778 * \mathrm{BF} 22+0.0101466 * \mathrm{BF} 23+0.00698606 * \mathrm{BF} 25 \\
&-0.000207216 * \mathrm{BF} 26+0.00126495 * \mathrm{BF} 27+0.762673 * \mathrm{BF} 29 ;\end{aligned}$} \\
\hline
\end{tabular}




\begin{tabular}{|c|c|}
\hline & NMID \\
\hline Simple Basis Functions & Complex Basis Functions \\
\hline $\begin{array}{l}\text { BF1 }=\max (0, \text { DRUGS }-223.76) \\
\text { BF2 }=\max (0,223.76-\text { DRUGS }) ; \\
\text { BF3 = } \max (0, \text { PHYSICIANS }-439.57) ; \\
\text { BF4 = } \max (0,439.57-\text { PHYSICIANS } ; \\
\text { BF8 = } \max (0,804.43-\text { HOSPITALS }) ; \\
\text { BF11 = } \max (0, \text { HOSPITALS - 514.91 }) ; \\
\text { BF18 = } \max (0,383.85-\text { OTHER_PROFESSIONALS }) ;\end{array}$ & 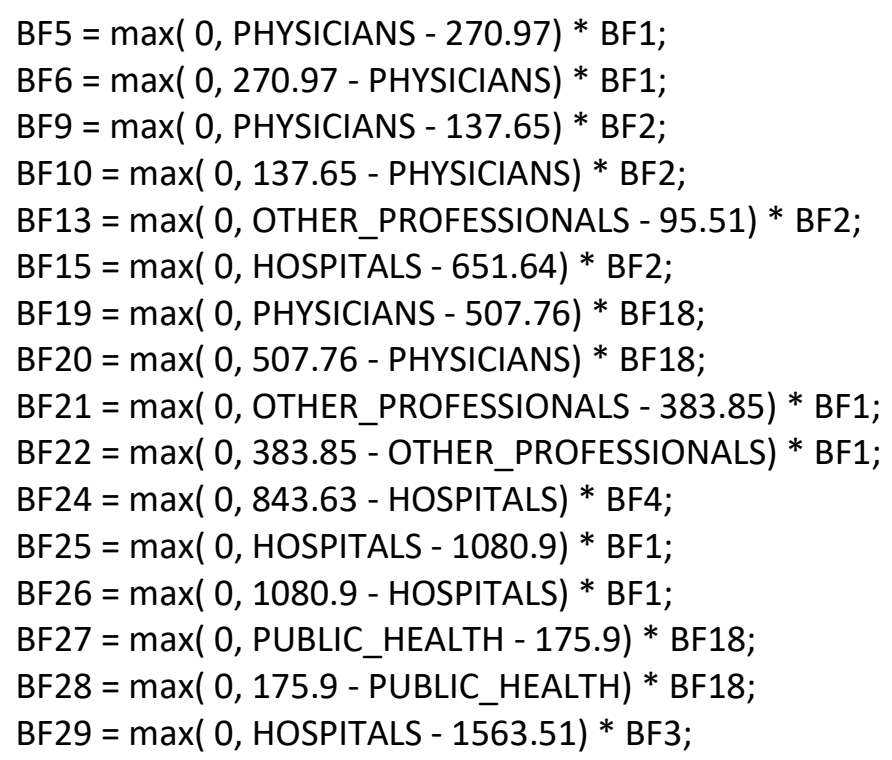 \\
\hline \multicolumn{2}{|c|}{ Final Model } \\
\hline \multicolumn{2}{|c|}{$\begin{aligned} & \mathrm{Y}=-103.348+2.33712 * \mathrm{BF} 2-1.43098 * \mathrm{BF} 3+0.00247316 * \mathrm{BF} 5 \\
&+0.0253861 * \mathrm{BF} 6-2.29838 * \mathrm{BF} 8+0.0616209 * \mathrm{BF} 9 \\
&-0.060763 * \mathrm{BF} 10+0.213914 * \mathrm{BF} 11-0.098403 * \mathrm{BF} 13 \\
&+0.0251088 * \mathrm{BF} 15+5.51872 * \mathrm{BF} 18+0.0455656 * \mathrm{BF} 19 \\
&-0.0205505 * \mathrm{BF} 20+0.00136348 * \mathrm{BF} 21-0.0128709 * \mathrm{BF} 22 \\
&+0.011363 * \mathrm{BF} 24-0.00128932 * \mathrm{BF} 25+0.00437602 * \mathrm{BF} 26 \\
&-0.0538521 * \mathrm{BF} 27+0.00570746 * \mathrm{BF} 28+0.00107148 * \mathrm{BF} 29\end{aligned}$} \\
\hline
\end{tabular}




\section{$\underline{\text { References }}$}

Berger, M. C., \& Messer, J. (2002). Public financing of health expenditures, insurance, and health outcomes. Applied Economics, 34(17), 2105-2113.

http://doi.org/10.1080/00036840210135665

Bilodeau, D., Crémieux, P.-Y., Jaumard, B., Ouellette, P., \& Vovor, T. (2004). Measuring Hospital Performance in the Presence of Quasi-Fixed Inputs: An Analysis of Québec Hospitals. Journal of Productivity Analysis, 21, 183-199.

Breiman, L. (Ed.). (1998). Classification and regression trees (Repr). Boca Raton: Chapman \& Hall [u.a.].

Charnes, A., \& Cooper, W. W. (1962). Programming with linear fractional functionals. Naval Research Logistics Quarterly, 9(3-4), 181-186. http://doi.org/10.1002/nav.3800090303

Charnes, A., Cooper, W. W., \& Rhodes, E. (1978). Measuring the efficiency of decision making units. European Journal of Operational Research, 2(6), 429-444.

http://doi.org/10.1016/0377-2217(78)90138-8

Chatal, O., André, C., Joumard, I., \& Nicq, C. (2008). Health Status Determinants (OECD Economics Department Working Papers No. 627). Retrieved from http://www.oecdilibrary.org/economics/health-status-determinants_240858500130

CIHI. (2015a). NHEX Series D1 National Health Expenditure Trends, 1975 to 2015. Canadian Institute for Health Information. Retrieved from https://www.cihi.ca/sites/default/files/document/nhex_2015_datatables_en.zip 
CIHI. (2015b, October). National Health Expenditure Trends, 1975 to 2015 - Methodology Notes. ClHI. Retrieved from https://www.cihi.ca/sites/default/files/document/nhex_methodological_notes_october 2015_en.pdf

Cobb, C., \& Douglas, P. (1928). A Theory of Production. The American Economic Review, 18(1), 139-165. Retrieved from http://www.jstor.org/stable/1811556

Coelli, T., \& Coelli, T. (Eds.). (2005). An introduction to efficiency and productivity analysis (2nd ed). New York: Springer.

Cooper, W. W., Seiford, L. M., \& Zhu, J. (Eds.). (2010). Handbook on data envelopment analysis (2nd rev. ed). New York, NY: Springer-Verlag New York Inc.

Crémieux, P.-Y., Meilleur, M.-C., Ouellette, P., Petit, P., Zelder, M., \& Potvin, K. (2005). Public and private pharmaceutical spending as determinants of health outcomes in Canada: Drug Spending and Outcomes. Health Economics, 14(2), 107-116. http://doi.org/10.1002/hec.922

Crémieux, P.-Y., Ouellette, P., \& Pilon, C. (1999). Health care spending as determinants of health outcomes. Health Economics, 8(7), 627-639. http://doi.org/10.1002/(SICI)10991050(199911)8:7<627::AID-HEC474>3.0.CO;2-8

Day, K., \& Tousignant, J. (2005, June). Health Spending, Health Outcomes, and Per Capita Income in Canada: A Dynamic Analysis. Economic and Fiscal Policy Branch, Departmetn of Finance. Retrieved from https://www.fin.gc.ca/pub/pdfs/wp2005-07e.pdf

Elola, J., Daponte, A., \& Navarro, V. (1995). Health indicators and the organization of health cre systems in Western Europe. Journal of Public Health, 85(10), 1397-1401. 
Farrell, M. J. (1957). The Measurement of Productive Efficiency. Journal of the Royal Statistical Society. Series A (General), 120(3), 253. http://doi.org/10.2307/2343100

Friedman, J. H. (1991). Multivariate Adaptive Regression Splines. The Annals of Statistics, 1-67. Gravelle, H. S. E., \& Backhouse, M. E. (1987). International Cross-Section Analysis of the Determination of Mortality. Social Science \& Medicine, 25(5), 427-441. Retrieved from file://C:/Users/user/Google\%20Drive/Kwadwo\%20Adu\%20Thesis/Literature/Economic s/Gravelle\%20\&\%20Backhouse\%20(1987)\%20-\%20International\%20CrossSection\%20Analysis\%20of\%20the\%20Determination\%20of\%20Mortality.pdf

Grossman, M. (1972). On the Concept of Health Capital and the Demand for Health. Journal of Political Economy, 80(2), 223-255. Retrieved from http://www.jstor.org/stable/1830580 Hanratty, M. J. (1996). Canadian National Health Insurance and Infant Health. The American Economic Review, 86(1), 276-284.

Hollingsworth, B. (2003). Non-Parametric and Parametric Applications Measuring Efficiency in Health Care. Health Care Management Science, 6(4), 203-218.

Hollingsworth, B. (2008). The measurement of efficiency and productivity of health care delivery. Health Economics, 17(10), 1107-1128. http://doi.org/10.1002/hec.1391

Hollingsworth, B., Dawson, P. J., \& Manidakis, N. (1999). Efficiency measurement of health care: a review of non-parametric methods and applications. Health Care Management Science, 2(3), 161-172.

Hutchison, B., Levesque, J.-F., Strumpf, E., \& Coyle, N. (2011). Primary Health Care in Canada: Systems in Motion. The Milbank Quarterly, 89(2), 256-288. 
Inglehart, J. K. (2000). Revisiting the Canadian health care system. The New Engliand Journal of Medicine, 342(26), 2007-2012.

Joumard, I., \& Häkkinen, U. (2007). Cross-Country Analysis of Efficiency in OECD Health Care Sectors (OECD Economics Department Working Papers No. 554). Retrieved from http://www.oecd-ilibrary.org/economics/cross-country-analysis-of-efficiency-in-oecdhealth-care-sectors_178861806081

Lubitz, J., Cai, L., Kramarow, E., \& Lentzner, H. (2003). Health, Life Expectancy, and Health Care Spending among the Elderly. New England Journal of Medicine, 349(11), 1048-1055. http://doi.org/10.1056/NEJMsa020614

Morgan, S., \& Cunningham, C. (2011). Population Aging and the Determinants of Healthcare Expenditures: The Case of Hospital, Medical and Pharmaceutical Care in British Columbia, 1996 to 2006. Healthcare Policy, 7(1), 68-79.

Nam, Y.-S., Kongsrud, P., Joumard, I., \& Price, R. (2004). Enhancing the Effectiveness of Public Spending (OECD Economics Department Working Papers No. 380). Retrieved from http://www.oecd-ilibrary.org/economics/enhancing-the-effectiveness-of-publicspending_355505224723

Naylor, C. D. (1999). Health care in Canada: incrementalism under fiscal duress. Health Affairs, 18(3), 9-26. http://doi.org/10.1377/hlthaff.18.3.9

Nicq, C., Joumard, I., \& André, C. (2010). Health Care Systems (OECD Economics Department Working Papers No. 769). Retrieved from http://www.oecdilibrary.org/economics/health-care-systems_5kmfp51f5f9t-en 
Nixon, J., \& Ulmann, P. (2006). The relationship between health care expenditure and health outcomes: Evidence and caveats for a causal link. The European Journal of Health Economics, 7(1), 7-18. http://doi.org/10.1007/s10198-005-0336-8

Or, Z. (2000). Determinants of Health Outcomes in Industrialised Countries: A Pooled, CrossCountry, Time-Series Analysis. OECD Economic Studies, 53-78.

Or, Z. (2001). Exploring the Effects of Health Care on Mortality Across OECD Countries (OECD Labour Market and Social Policy Occasional Papers No. 46). Retrieved from http://www.oecd-ilibrary.org/social-issues-migration-health/exploring-the-effects-ofhealth-care-on-mortality-across-oecd-countries_716472585704

Osei-Bryson, K.-M. (2014a). Overview on Decision Tree Induction. In Advances in Research Methods for Information Systems Research (Vol. 34, pp. 15-22). Springer.

Osei-Bryson, K.-M. (2014b). Overview on Multivariate Adaptive Regression Splines. In Advances in Research Methods for Information Systems Research (Vol. 34, pp. 93-107). Springer.

Reinhardt, U. E. (2003). Does The Aging Of The Population Really Drive The Demand For Health Care? Health Affairs, 22(6), 27-39. http://doi.org/10.1377/hlthaff.22.6.27

Retzlaff-Roberts, D., Chang, C. F., \& Rubin, R. M. (2004). Technical efficiency in the use of health care resources: a comparison of OECD countries. Health Policy, 69(1), 55-72. http://doi.org/10.1016/j.healthpol.2003.12.002

Self, S., \& Grabowski, R. (2003). How effective is public health expenditure in improving overall health? A cross-country analysis. Applied Economics, 35(7), 835-845. http://doi.org/10.1080/0003684032000056751 
Solow, R. M. (1956). A Contribution to the Theory of Economic Growth. The Quarterly Journal of Economics, 70(1), 65-94.

Spinks, J., \& Hollingsworth, B. (2009). Cross-country comparisons of technical efficiency of health production: a demonstration of pitfalls. Applied Economics, 41(4), 417-427. http://doi.org/10.1080/00036840701604354

Worthington, A. (2004). Frontier Efficiency Measurement in Health Care: A Review of Empirical Techniques and Selected Applications. Medical Care Research and Review, 61(2), 135170.

Zweifel, P. (1999). Ageing of population and health care expenditure: A red herring? Health Economics, 8, 485-4996. 


\section{List of Acronyms}

BF: Basis Function

BCC: Banker, Charnes, and Cooper

CRS: Constant Returns to Scale

CCR: Charnes Cooper and Rhodes

DEA: Data Envelopment Analysis

DRS: Decreasing Returns to Scale

DT: Decision Tree

EMS: Efficiency Measurement System

FLE65: Female Life Expectancy at age 65

FLEB: Female Life Expectancy at Birth

FPYLLTC: Female Potential Years of Life Lost due to Deaths from Treatable Causes

IRS: Increasing Returns to Scale

MARS: Multivariate Adaptive Regression Splines

MLE65: Male Life Expectancy at age 65

MLEB: Male Life Expectancy at Birth

MPSS: Most Productive Scale Size

MPYLLTC: Male Potential Years of Life Lost due to Deaths from Treatable Causes

NIRS: Non-Increasing Returns to Scale

NMID: Number of Male Infant Deaths

NFID: Number of Female Infant Deaths

PYLLTC: Potential Years of Life Lost due to Deaths from Treatable Causes

StatsCan: Statistics Canada

SPM: Salford Predictive Modeler 


\section{Glossary of Terms}

Algorithm: A process or set of rules used to perform calculations or solve problems.

Categorical/Nominal Variable: A variable whose value may fall into multiple, un-ranked categories.

Continuous variable: A variable which can take an infinite number of possible values between the minimum and maximum.

Decision Making Unit: A term used in DEA referring to a system which converts inputs to outputs.

Decision Tree: A category of predictive induction algorithms which, when visualized, resemble an inverted tree.

Dependent Variable: A variable whose value/variation depends on another variable; usually notated as the " $y$ " variable.

Function: A relationship expressed using multiple variables.

Independent Variable: A variable whose value/variation does not depend on that of another; usually notated as the " $x$ " variable.

Induction: A method of inference that uses assumptions taken from sample of observations to make generalizations to a broader conclusion.

Over-fitting: Over-fitting occurs when a statistical model is constructed in a way that demonstrates the trends in sample of data it is constructed from and therefore cannot be generalized.

Piecewise Function: A function that is composed of a combination of multiple, smaller functions.

Regression Analysis: A statistical method for estimating and modeling the relationships between variables. A simple regression analysis usually focuses on the relationship between two variables, one dependent and one independent. A multiple regression analysis includes upwards of two independent variables.

R-Squared Statistic: A measure of the proportion of variance in the dependent variable that is predicted by the independent variable(s) used a regression analysis.

Technical Efficiency: The effectiveness with which a set of inputs is transformed into output. To be technically efficient means to minimize the amount of input used to produce a maximized amount of output.

Variance: The description of how widely individual observations in a group differ from the average observation. 